SRNL-STI-2012-00018

Revision 1

\title{
Glycolic-Nitric Acid Flowsheet Demonstration of the DWPF Chemical Process Cell with Sludge and Supernate Simulants
}

\author{
D.P. Lambert \\ M.E. Stone \\ J.D. Newell \\ D.R. Best \\ J.R. Zamecnik
}

August 2012

Savannah River National Laboratory

Savannah River Nuclear Solutions, LLC

Aiken, SC 29808

Prepared for the U.S. Department of Energy under

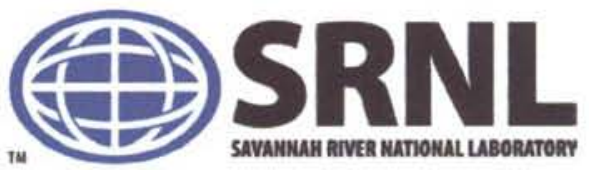
contract number DE-AC09-08SR22470. 
SRNL-STI-2012-00018

Revision 1

\section{DISCLAIMER}

This work was prepared under an agreement with and funded by the U.S. Government. Neither the U.S. Government or its employees, nor any of its contractors, subcontractors or their employees, makes any express or implied:

1. warranty or assumes any legal liability for the accuracy, completeness, or for the use or results of such use of any information, product, or process disclosed; or

2. representation that such use or results of such use would not infringe privately owned rights; or

3. endorsement or recommendation of any specifically identified commercial product, process, or service.

Any views and opinions of authors expressed in this work do not necessarily state or reflect those of the United States Government, or its contractors, or subcontractors.

\section{Printed in the United States of America}

Prepared for

U.S. Department of Energy 
Keywords: Alternative Reductant, DWPF, CPC, glycolic acid, hydrogen

Retention: Permanent

\title{
Glycolic-Nitric Acid Flowsheet Demonstration of the DWPF Chemical Process Cell with Sludge and Supernate Simulants
}

\author{
D.P. Lambert \\ M.E. Stone \\ J.D. Newell \\ D.R. Best \\ J.R. Zamecnik
}

August 2012

Savannah River National Laboratory

Savannah River Nuclear Solutions, LLC Aiken, SC 29808

Prepared for the U.S. Department of Energy under contract number DE-AC09-08SR22470. 
SRNL-STI-2012-00018

Revision 1

\section{REVIEWS AND APPROVALS}

\section{AUTHORS:}

D.P. Lambert, Process Technology Programs

Date

M.E. Stone, Process Technology Programs

Date

J.D. Newell, Process Technology Programs

Date

D.R. Best, Engineering Process Development

Date

J.R. Zamecnik, Process Technology Programs

Date

TECHNICAL REVIEW:

D.C. Koopman, Process Technology Programs

Date

APPROVAL:

C.C. Herman, Manager Date

Process Technology Programs

S.L. Marra, Manager

Date

Environmental \& Chemical Process Technology Research Programs

J.E. Occhipinti, Manager

Date

Waste Solidification Engineering 


\section{EXECUTIVE SUMMARY}

Testing was completed to demonstrate the viability of the newly developed glycolic/nitric flowsheet for processing in the Defense Waste Processing Facility's (DWPF) Chemical Process Cell (CPC). The Savannah River National Laboratory (SRNL) initiated a sludge matrix study to evaluate the impact on CPC processing. Four sludge simulants were designed to cover a broad insoluble solid composition range to bracket future sludge batches. The first pair of sludge parameters was high iron/low aluminum versus low iron/high aluminum (referred to as HiFe or LoFe in this report). The second pair of sludge parameters was high calcium-manganese/low nickel, chromium, and magnesium versus low calcium-manganese/high nickel, chromium, and magnesium (referred to as HiMn or LoMn in this report). In addition, a simple supernate simulant was prepared to match the composition of the matrix simulants.

Ten experiments (GF34 to GF37 and GF34b, GF34c, GF36b, GF36c, GF37b and GF38) were completed to demonstrate the glycolic-nitric flowsheet viability using the sludge matrix simulants at a nominal $1 \mathrm{M} \mathrm{Na}$ washing endpoint. In addition, two experiments were performed with less washed simulants (GF40, 1.6 M Na and GF41, 1.9 M Na endpoints) to demonstrate the viability of processing these sludges. Five supernate experiments (GF39a-GF39e) were performed to better understand the reaction sequence, particularly the reduction and stripping of mercury.

Composition and physical property measurements were made on the Sludge Receipt and Adjustment Tank (SRAT) and Slurry Mix Evaporator (SME) products. Composition measurements were made on the composited condensates from the Mercury Water Wash Tank (MWWT), and Formic Acid Vent Condenser (FAVC), on the ammonia scrubber solution, and on SRAT samples pulled throughout the SRAT cycle. Updated values for glycolate and formate loss, nitrite-to-nitrate conversion, and oxalate formation were found that can be used in the acid calculations for future process simulations with the glycolic-nitric flowsheet.

Preliminary results of the initial testing indicate:

- Hydrogen generation rate was below detection limits $(<1.4 \mathrm{E}-3 \mathrm{lb} / \mathrm{hr})$ DWPF-scale or $<0.005 \mathrm{vol} \%)$ throughout all SRAT cycles with matrix simulants. Hydrogen generation rate was above detection limits for the less washed simulants $(3.2 \mathrm{E}-3 \mathrm{lb} / \mathrm{hr}$ DWPF-scale or $0.009 \mathrm{vol} \%$ ) due to the higher acid stoichiometry and the lower offgas purge.

- Hydrogen generation rate was below $0.0258 \mathrm{lb} / \mathrm{hr}$ DWPF-scale (11.6\% of DWPF SME limit) throughout all SME cycles with matrix simulants. The small amount of generated hydrogen with the nominal washing endpoint is attributed to formic acid added with the frit. When formic acid was not added with the frit in the underwashed sludge runs (GF40 and GF41), the maximum hydrogen seen was $1.8 \mathrm{E}-3 \mathrm{lb} / \mathrm{hr}$ DWPF scale $(0.81 \%$ of DWPF SME limit).

- Mercury was both reduced and stripped without formic acid. The mercury concentration of the SRAT product was below the $0.8 \mathrm{wt} \%$ target in eight of the runs and below $0.92 \mathrm{wt} \%$ in the other four runs.

- $\quad$ Nitrite in the SRAT product was $<100 \mathrm{mg} / \mathrm{kg}$ slurry for all runs.

- $\quad$ Foaminess was not an issue using the nominal antifoam addition strategy or with reduced antifoam in these tests. 
- $\quad$ High wt \% total solids were achieved while staying within rheological limits which makes the glycolic acid/nitric acid flowsheet an improvement for processing more viscous sludges. However, there may be a tradeoff between excessive dissolution of metals and thinner rheology.

- $\quad$ The $\mathrm{pH}$ remained steady throughout processing (i.e. no $\mathrm{pH}$ rebound) potentially leading to more consistent processing during the CPC. The SRAT and SME products $\mathrm{pH}$ varied from $3.5-5.0$ for the $100 \%$ and $130 \%$ acid stoichiometry runs, significantly lower than is typical of the Baseline (nitric acid/formic acid) flowsheet.

- $\quad$ The testing apparatus has been significantly modified to improve processing with high viscosity slurries. Testing of the old style and new style rig identified no differences in CPC processing, including steam stripping of $\mathrm{Hg}$.

- $\quad$ The SRAT lower air purge was demonstrated in Run GF34c and adapted in GF40 and GF41. Based on these results, the SRAT purge can be reduced from $190 \mathrm{scfm}$ to $93.7 \mathrm{scfm}$ without negatively impacting processing.

- $\quad$ Runs GF40 and 41 demonstrated that processing of less washed sludges is viable with this flowsheet. However, this flowsheet has not been demonstrated with ARP, MCU or actual waste.

- $\quad$ Several processing improvements were demonstrated in these runs including adding acid during heat-up, adding both acids at higher volumetric flowrates than are currently used in DWPF, and concentrating the SRAT during acid addition. Each of these improvements has the potential to shorten CPC processing time.

\section{Recommendations Applying to Glycolic-Nitric Acid Flowsheet}

The glycolic-nitric flowsheet is recommended as a viable flowsheet alternative to the Baseline DWPF flowsheet. In the testing that has been performed to date, this flowsheet meets or outperforms the current flowsheet in minimizing off-gas generation, removing mercury, and producing a rheologically thinner product. Previous testing with glycolic/formic acid mixtures demonstrated a wide processing window regarding both the glycolic-formic ratio and acid stoichiometry. The addition of glycolic acid leads to SRAT and SME products that are rheologically less viscous which means that more concentrated products can be produced, leading to potentially higher waste throughput per batch. In addition, the combination of lower $\mathrm{pH}$ processing and the complexing power of glycolic acid leads to the dissolution of more metals, which may minimize deposits in the CPC processing vessels and prevent the fouling of steam coils. Follow up testing is recommended in the following areas:

- Improve glycolate and oxalate analyses. The majority of the glycolate results reported were correct. However, there are issues with anion and cation deposition on the column of the Ion Chromatograph (IC), causing higher than expected glycolate and oxalate in blanks and some samples. Both Process Science and Analytical Laboratory (PSAL) and Analytical Development (AD) have reported results that have varied significantly from expectations. Modification to the sample preparation method is likely needed to improve analytical accuracy and minimize the cleaning and replacement of the IC column. An alternative to the IC measurement of glycolate should also be considered.

- $\quad$ Determine the appropriate REDOX model for the glycolic-nitric flowsheet. The REDOX model may need more terms due to the more extensive reduction of some metals, including $\mathrm{Mn}$ and $\mathrm{Fe}$. In addition, accurate measurement of glycolate (and possibly oxalate) and nitrate is needed to accurately predict REDOX. REDOX testing 
of the matrix sludges should be repeated using acceptable frits that meet Product Composition Control System (PCCS).

- Test the glycolic-nitric flowsheet at acid stoichiometries of less than $100 \%$. Demonstration of this flowsheet at an acid stoichiometry of $<100 \%$ is recommended and might be useful for mercury stripping.

- Demonstrate the glycolic-nitric flowsheet (previously demonstrated in SRAT cycle with 80:20 glycolic:formic acid blend) with actual waste in SRNL Shielded Cells SRAT and SME processing, to include periodic slurry sampling throughout the SRAT and SME processing along with a glass REDOX measurement.

- $\quad$ Add the nitric and glycolic acid flowrate at the same scaled molar flowrate as formic acid to minimize glycolic-nitric flowsheet batch time. This has been demonstrated in these tests.

- $\quad$ The nitric acid can be added during heat-up to decrease the SRAT cycle time. The nitric acid primarily neutralizes soluble base species in the slurry with little offgas generation.

- Improve understanding of process chemistry, the decomposition of glycolate and the production of oxalate which are important to REDOX.

- Improve understanding of mercury reduction, stripping and accumulation during processing. Determine whether alternative equipment or processing changes are needed to maximize the collection of mercury in the Mercury Water Wash Tank.

- If confirmed by actual waste testing and larger scale testing with simulants, the antifoam addition can be reduced for this flowsheet. The addition of $100 \mathrm{mg} / \mathrm{kg}$ prior to glycolic acid addition, $100 \mathrm{mg} / \mathrm{kg}$ prior to boiling and $100 \mathrm{mg} / \mathrm{kg}$ each 12 hours of processing was adequate during simulant testing.

- More rigorous data collection is needed to validate the OLI aqueous model's solubility predictions with sample results. The methodology is summarized in the discussion.

\section{Recommendations Applying to both Baseline and Glycolic-Nitric Acid Flowsheet}

- Testing should be completed with alternate forms of ruthenium to determine whether the elimination of the chloride added as ruthenium chloride would improve the reduction and stripping of the mercury. Testing should be completed with the Baseline and glycolic-nitric flowsheets. 
TABLE OF CONTENTS

TABLE OF CONTENTS ....................................................................................................... viii

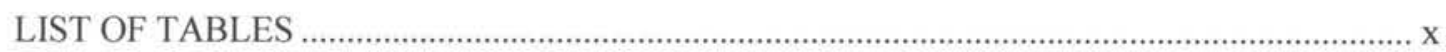

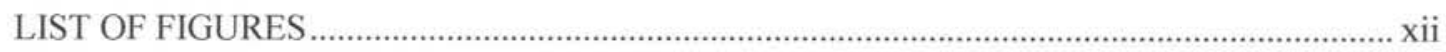

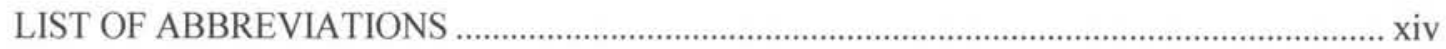

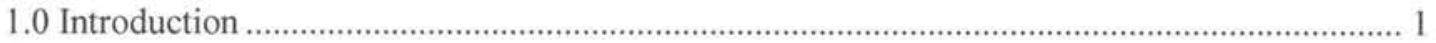

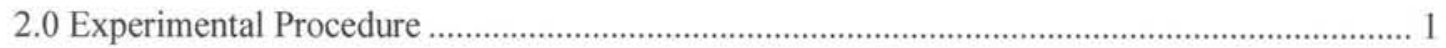

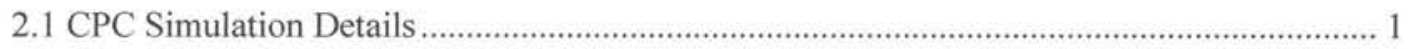

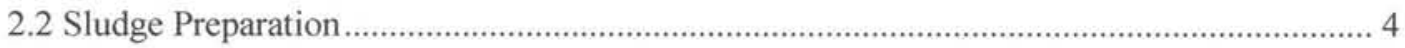

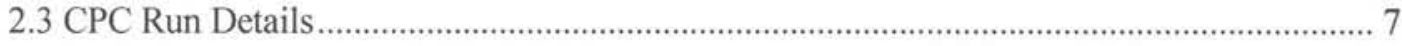

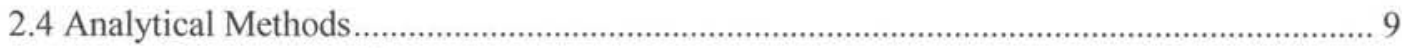

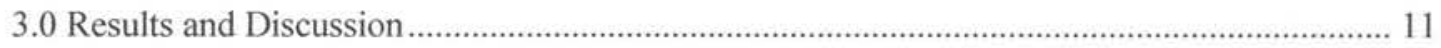

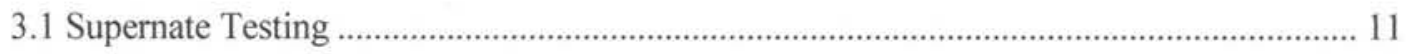

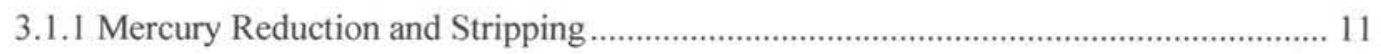

3.1.2 Nitrite and Carbonate Destruction........................................................................... 14

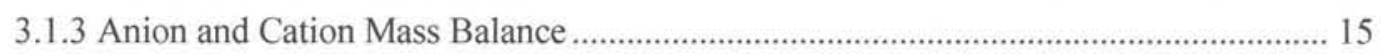

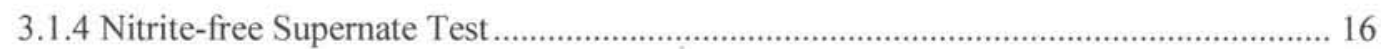

3.1.5 Conclusions from Supernate Testing ……..................................................................... 16

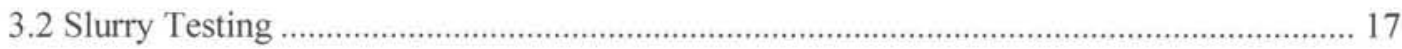

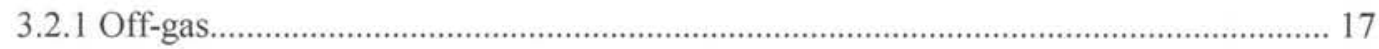

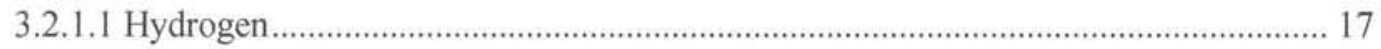

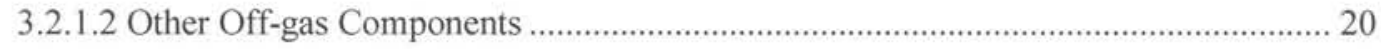

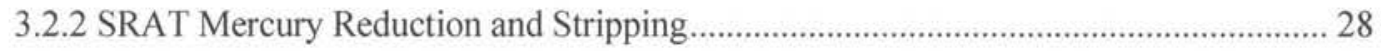

3.2.3 SRAT Data

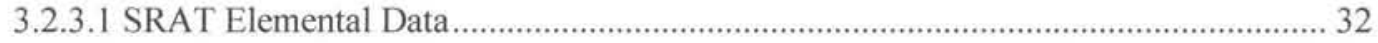

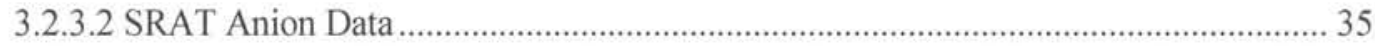

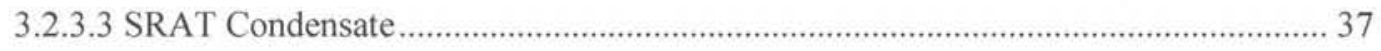

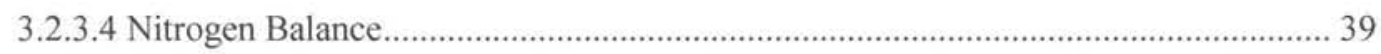

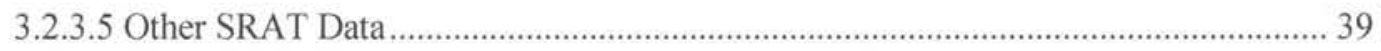

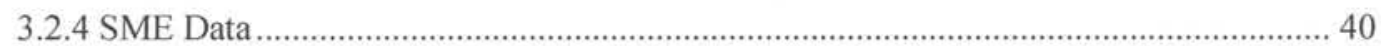

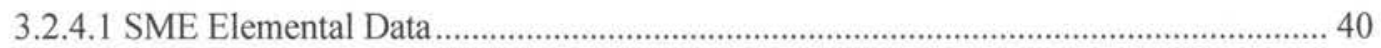

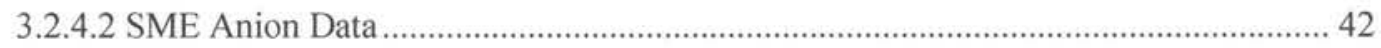

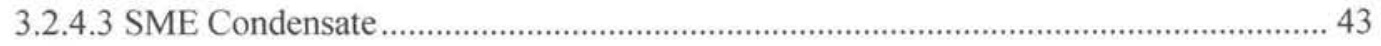

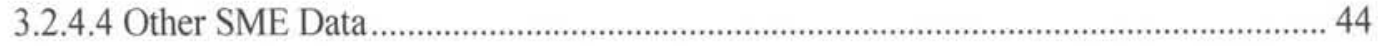


SRNL-STI-2012-00018

Revision 1

3.2.5 Supernate Chemistry -- Dissolution of Metals and Solubility of Anions....................... 44

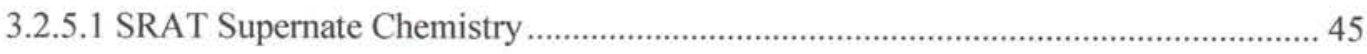

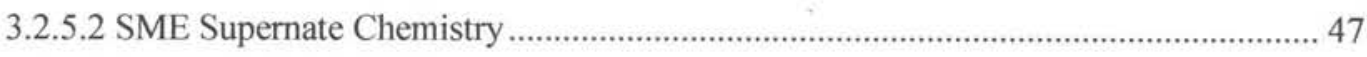

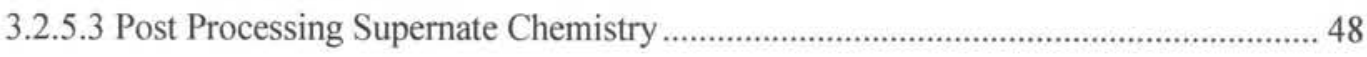

3.2.5.4 Improved Understanding of Supernate Chemistry ...................................................... 48

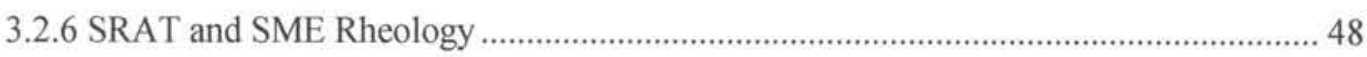

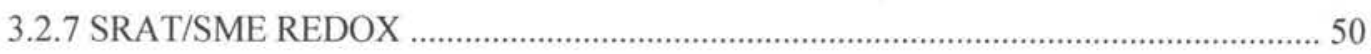

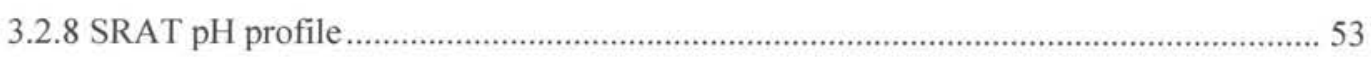

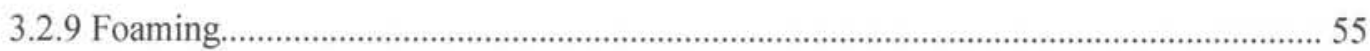

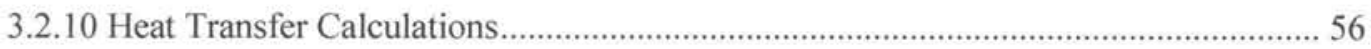

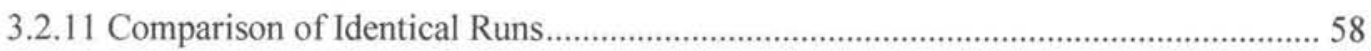

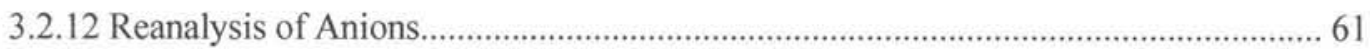

3.2.13 Less Washed Sludge Processing .............................................................................. 61

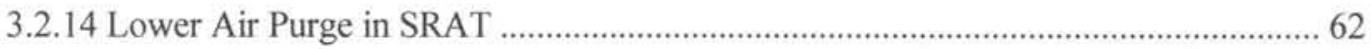

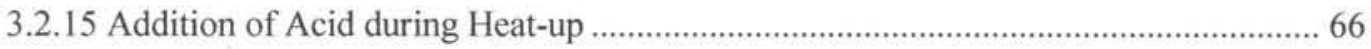

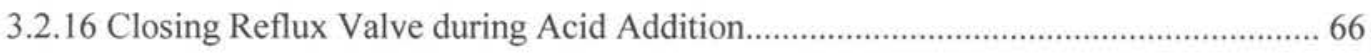

3.2.17 Processing without Formic Acid in the Frit Slurry ................................................... 67

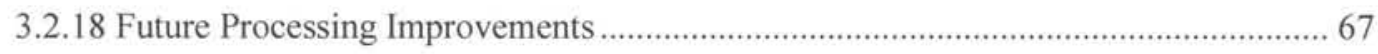

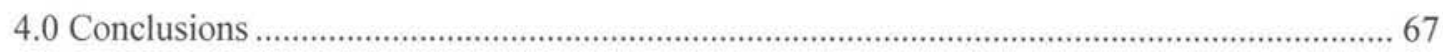



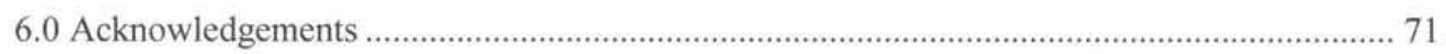

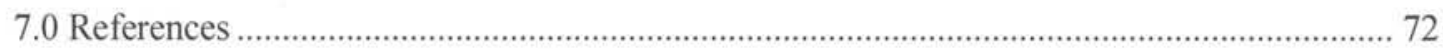




\section{LIST OF TABLES}

Table 2-1. Composition of Sludge Simulants.

Table 2-2. Mercury and Noble Metal Composition Added to Sludge Simulants, wt\% Total Solids Basis.

Table 2-3. Composition of Supernate Simulant

Table 2-4. Mercury and Noble Metal Composition Added to Supernate Simulants, wt $\%$ Total Solids Basis

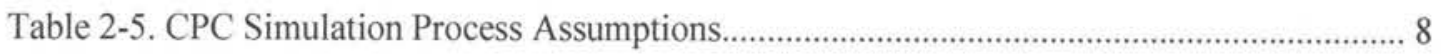

Table 2-6. Mass Spectrometer Calibration Gases ........................................................................... 10

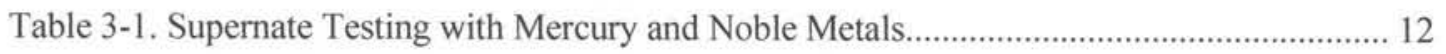

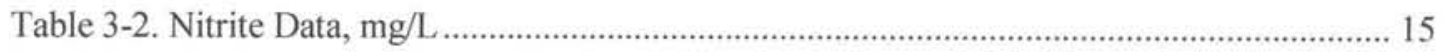

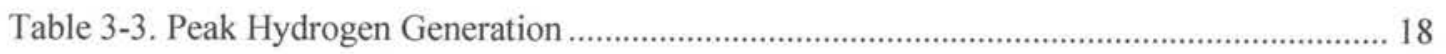

Table 3-4. Comparison of SRAT Carbon Dioxide Generation Data................................................. 21

Table 3-5. Comparison of SME Carbon Dioxide Generation Data................................................. 22

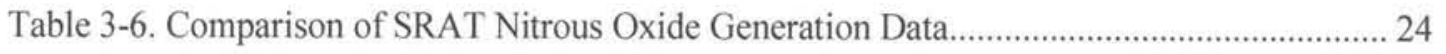

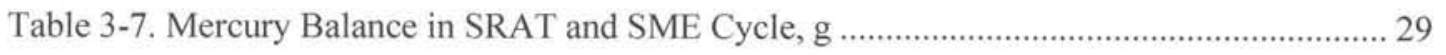

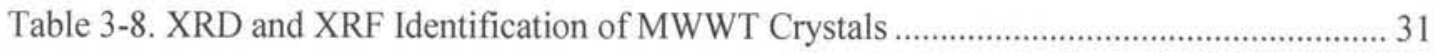

Table 3-9. SRAT Product Slurry PSAL Elemental Data, wt \% calcined solids basis.................... 33

Table 3-10. SRAT Product Supernate PSAL Elemental Data, mg/L supernate basis.................... 34

Table 3-11. Major Components: SRAT Product \% of Element Dissolved ...................................... 35

Table 3-12. SRAT Product Slurry PSAL Anion Data, mg/kg Slurry Basis .................................... 36

Table 3-13. SRAT Product Filtrate PSAL Anion Data, mg/L Supernate Basis ............................. 36

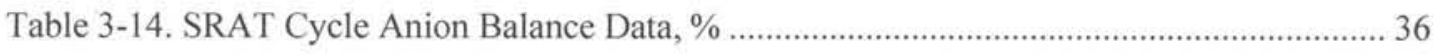

Table 3-15. \% Anion Dissolved in SRAT Products ........................................................................ 37

Table 3-16. SRAT Product AD and PSAL Anion with Comparison to AD TOC, $\mathrm{mg} / \mathrm{kg}$............ 37

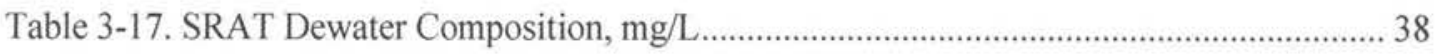

Table 3-18. Post SRAT MWWT Composition ………....................................................................... 38

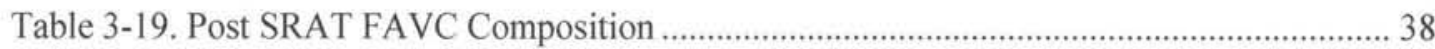

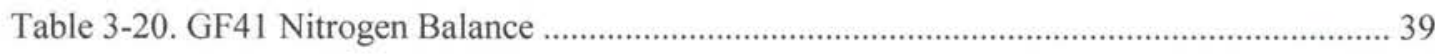




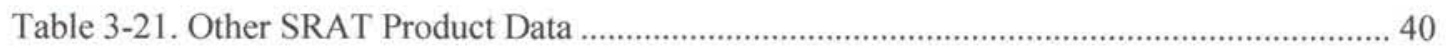

Table 3-22. SME Product Slurry Elemental Data, wt \% calcined solids basis ............................. 41

Table 3-23. SME Product Supernate Elemental Data, mg/L supernate basis ............................... 42

Table 3-24. SME Product Slurry Anion Data, mg/kg Slurry Basis................................................. 43

Table 3-25. SME Product Filtrate Anion Data, mg/L Supernate Basis.......................................... 43

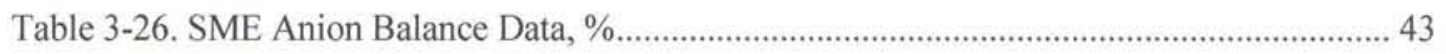

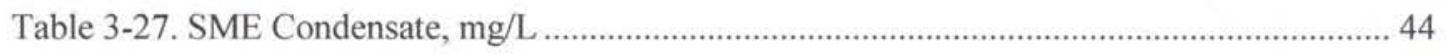

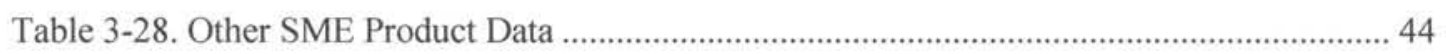

Table 3-29. Major Components: SME Product \% of Anion Soluble ............................................... 47

Table 3-30. Major Components: SME Product \% of Element Dissolved ....................................... 48

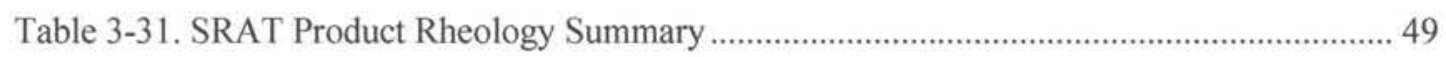

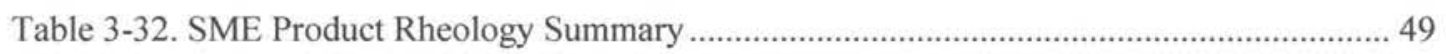

Table 3-33. Post Concentration SME Product solids content........................................................... 49

Table 3-34. SME product data for REDOX calculations, $\mathrm{Fe}^{2+} / \mathrm{LFe}$............................................... 51

Table 3-35. Repeat Analysis of SME anion data for REDOX calculations, $\mathrm{Fe}^{2+} / \mathrm{LFe} \ldots \ldots \ldots \ldots \ldots . . . . . . .52$

Table 3-36. Change in Anion Concentration due to Reanalysis of SME Product Samples ........... 52

Table 3-37. Spiked Recovery of SME Product Samples, $\mathrm{mg} / \mathrm{kg}$ slurry ….................................... 52

Table 3-38. TOC Analysis and Calculation of SME Product Samples, mg/kg slurry.................... 53

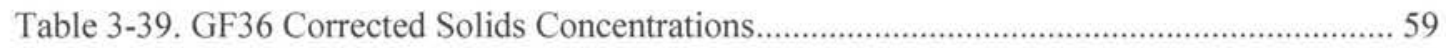

Table 3-40. Analyses of Interest of Duplicate Runs, Anions and Solids Concentrations Corrected

Table 3-41. Anion and TOC Analyses for Runs GF36b, 36c, 37b and 38, mg/kg...................... 61

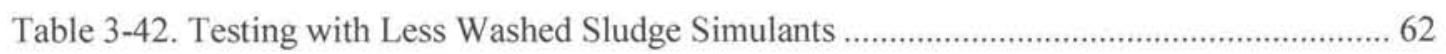

Table 3-43. MWWT Mercury Recovery for Runs GF40, 41, 2.0MNa, 2.5M Na........................ 67 


\section{LIST OF FIGURES}

Figure 2-1. Schematic of CPC Equipment Set-Up ....................................................................... 2

Figure 2-2. Definition of Sludge Matrix Simulants....................................................................... 5

Figure 3-1. Photographs of GF39a before and after SRAT cycle (Supernate plus HgO) ............. 13

Figure 3-2. Photographs of GF39b before and after SRAT cycle (Supernate plus $\mathrm{HgO}$ and noble

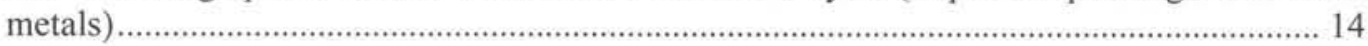

Figure 3-3. Supernate Run GF39b Predicted and Measured Anion Concentration ...................... 15

Figure 3-4. Supernate Run GF39b Predicted and Measured Cation Concentration........................ 16

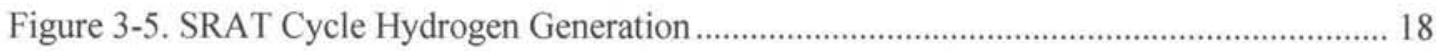

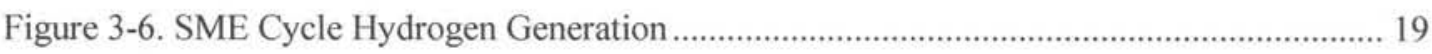

Figure 3-7. MS and GC Hydrogen Concentration......................................................................... 20

Figure 3-8. Carbon Dioxide Generation in SRAT cycles, lb/hr DWPF Scale .............................. 22

Figure 3-9. Carbon Dioxide Generation in SME cycles, lb/hr DWPF Scale ................................. 23

Figure 3-10. Nitrous Oxide Generation in SRAT cycles, lb/hr DWPF Scale .............................. 24

Figure 3-11. Nitrogen, Oxygen, Carbon Dioxide, $\mathrm{NO}_{\mathrm{x}}$ Generation in GF40 SRAT Cycle .......... 25

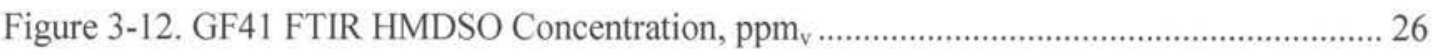

Figure 3-13. GF41 Carbon Dioxide Comparison between GF, MS and FTIR, volume \% ........... 27

Figure 3-14. GF41 $\mathrm{NO}_{2}$, $\mathrm{NO}$, or $\mathrm{N}_{2} \mathrm{O}$ GC, $\mathrm{MS}$ and FTIR, volume \% ........................................ 28

Figure 3-15. Mercury concentration versus time in Selected SRAT and SME cycles.................. 30

Figure 3-16. Mercury and Palladium Concentration for GF37b and GF38 SRAT Cycles ........... 31

Figure 3-17. Photo of SRAT Product Samples 11/30/2011 (4 days after SME cycle) ................. 45

Figure 3-18. Order of Dissolution of "Major Metals" During SRAT Processing ........................... 46

Figure 3-19. Order of Dissolution of "Minor Metals" During SRAT Processing ......................... 46

Figure 3-20.SME Product Rheology of Concentrated Subsamples................................................ 50

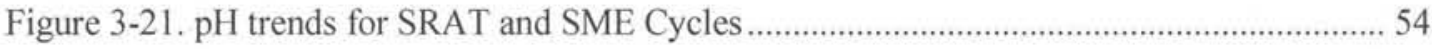

Figure 3-22. pH trends for Duplicate GF36 SRAT Cycles ............................................................ 54

Figure 3-23. HDMSO Concentration during GF41 SRAT and SME cycle ................................. 55

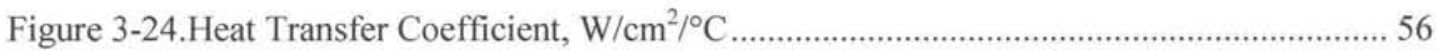

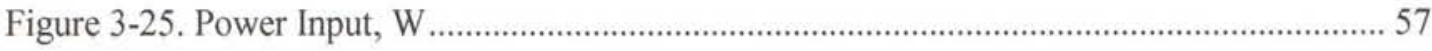


Figure 3-26. Photograph of Fouled Heating Rod after Run GF37 SME ...................................... 58

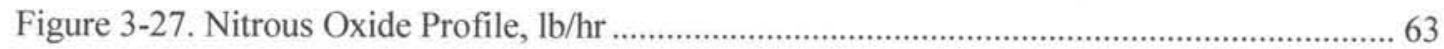

Figure 3-28. Glycolic-Nitric and Baseline Flowsheet SRAT Hydrogen Concentration Profile,

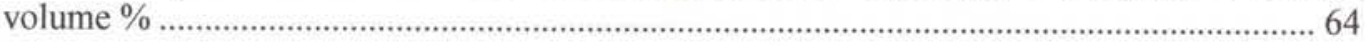

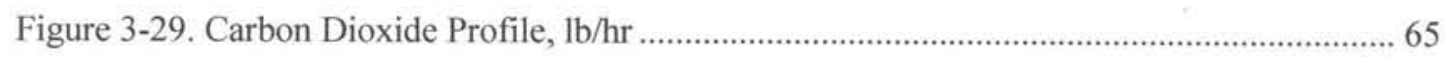

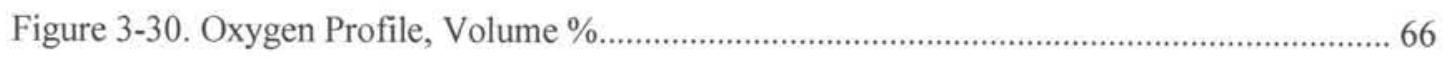




\section{LIST OF ABBREVIATIONS}

\begin{tabular}{|c|c|}
\hline $\mathrm{AD}$ & Analytical Development \\
\hline CPC & Chemical Process Cell \\
\hline DWPF & Defense Waste Processing Facility \\
\hline GC & Gas Chromatograph \\
\hline FAVC & Formic Acid Vent Condenser \\
\hline FTIR & Fourier Transform InfraRed \\
\hline HMDSO & Hexamethyldisiloxane \\
\hline $\mathrm{HM}$ & H-Canyon Modified (PUREX) \\
\hline IC & Ion Chromatography \\
\hline ICP-AES & Inductively Coupled Plasma-Atomic Emission Spectroscopy \\
\hline MS & Mass Spectrometer \\
\hline MWWT & Mercury Water Wash Tank \\
\hline NM & Not Measured \\
\hline PSAL & Process Science Analytical Laboratory \\
\hline PUREX & Plutonium - URanium Extraction \\
\hline REDOX & Reduction/Oxidation \\
\hline SME & Slurry Mix Evaporator \\
\hline SMECT & Slurry Mix Evaporator Condensate Tank \\
\hline SRAT & Sludge Receipt and Adjustment Tank \\
\hline SRNL & Savannah River National Laboratory \\
\hline SRR & Savannah River Remediation \\
\hline SRS & Savannah River Site \\
\hline TOC & Total Organic Carbon Analysis \\
\hline TT\&QAP & Task Technical and Quality Assurance Plan \\
\hline XRD & X-ray Diffraction \\
\hline XRF & X-ray Fluorescence \\
\hline
\end{tabular}




\subsection{Introduction}

Savannah River Remediation (SRR) is evaluating changes to its current DWPF flowsheet to improve processing cycle times. This will enable the facility to support higher canister production while maximizing waste loading. Higher throughput is needed in the CPC since the installation of the bubblers into the melter has increased melt rate. Due to the significant maintenance required for the DWPF gas chromatographs (GC) and the potential for production of flammable quantities of hydrogen, reducing or eliminating the amount of formic acid used in the CPC is being developed. Earlier work at Savannah River National Laboratory has shown that replacing formic acid with an 80:20 molar blend of glycolic and formic acids has the potential to remove mercury in the SRAT without any significant catalytic hydrogen generation. ${ }^{1,2,3}$ This report summarizes the research completed to determine the feasibility of processing without formic acid.

In earlier development of the glycolic-formic acid flowsheet, one run (GF8) ${ }^{2}$ was completed without formic acid. It is of particular interest that mercury was successfully removed in GF8, no formic acid at $125 \%$ stoichiometry. Glycolic acid did not show the ability to reduce mercury to elemental mercury in initial screening studies, which is why previous testing focused on using the formic/glycolic blend.

The objective of the testing detailed in this document is to determine the viability of the nitricglycolic acid flowsheet in processing sludge over a wide compositional range as requested by DWPF. ${ }^{4}$ This work was performed under the guidance of Task Technical and Quality Assurance Plan (TT\&QAP). ${ }^{5}$ The details regarding the simulant preparation and analysis have been documented previously. ${ }^{6}$

\subsection{Experimental Procedure}

The experimental apparatus used in these experiments is typical for DWPF SRAT/SME testing. The four experiments were performed in 4-L kettles. The test equipment included a GC to measure off-gas composition, an ammonia scrubber, and a $\mathrm{pH}$ meter. In all runs, the SRNL acid calculation spreadsheet ${ }^{7}$ used the Koopman equation ${ }^{8}$ to determine acid addition quantities and dewater targets.

\subsection{CPC Simulation Details}

The SRAT 4-L rigs were assembled following the guidelines of SRNL-3100-2011-00127. ${ }^{9}$ The intent of the equipment is to functionally replicate the DWPF processing vessels. Each glass kettle is used to replicate both the SRAT and SME, and it is connected to the SRAT Condenser, the MWWT, and the FAVC. The Slurry Mix Evaporator Condensate Tank (SMECT) is represented by a sampling bottle that is used to remove condensate through the MWWT. For the purposes of this paper, the condensers and wash tank are referred to as the off-gas components. A sketch of the experimental setup is given in Figure 2-1. 


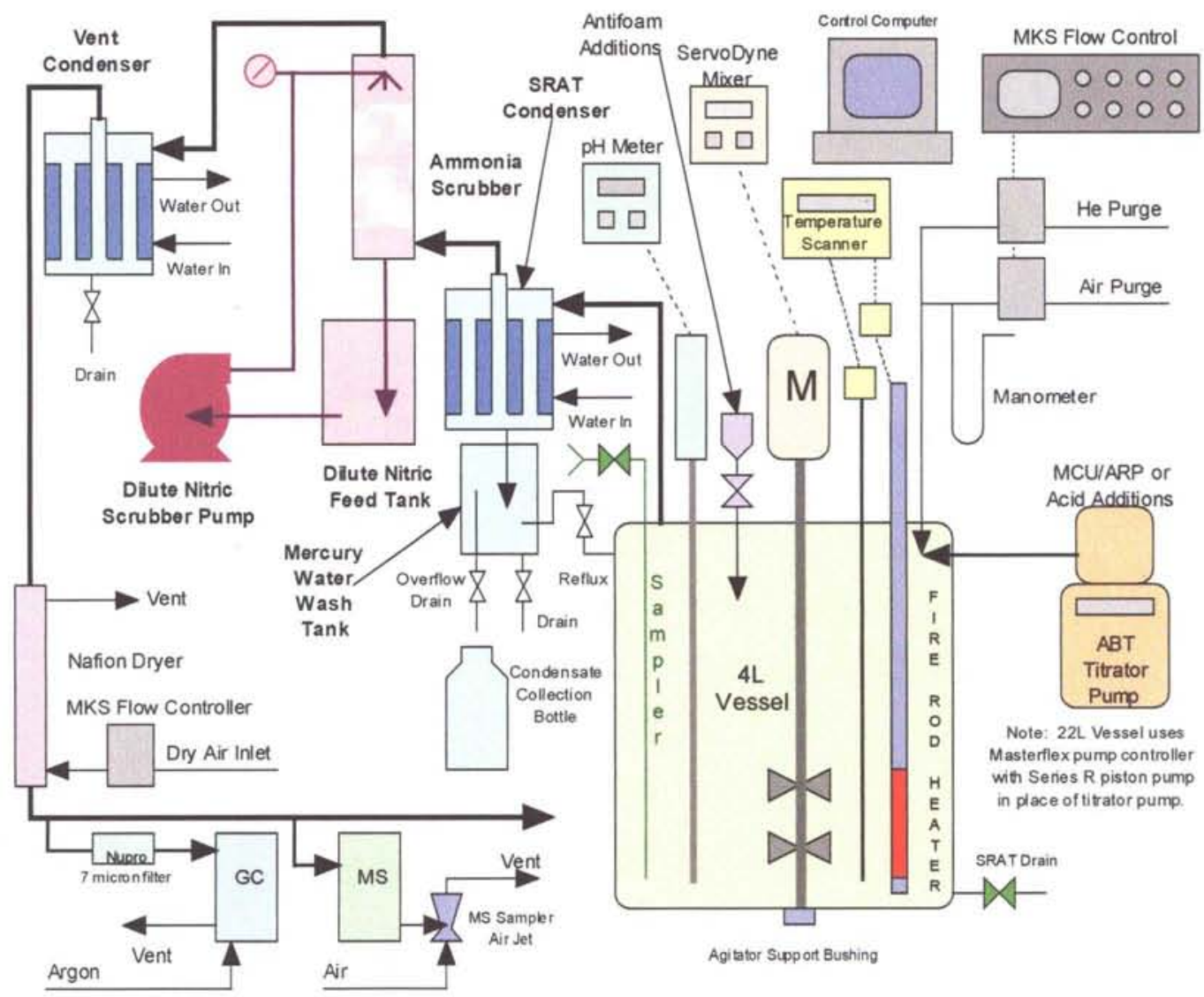

Figure 2-1. Schematic of CPC Equipment Set-Up

There were several notable changes to the CPC equipment set-up:

1. Used two heating rods to better simulate the steam coils instead of a heating mantle

2. Used Series R piston pump instead of titrator pump

3. The control system was modified to control the heating rod so that it could not reach a temperature of $>160^{\circ} \mathrm{C}$, the approximate maximum temperature of the DWPF steam coils

The runs were performed using the guidance of Procedure ITS- $0094^{10}$ ("Laboratory Scale Chemical Process Cell Simulations") of Manual L29. Off-gas hydrogen, oxygen, nitrogen, nitrous oxide, and carbon dioxide concentrations were measured during the experiments using in-line instrumentation. Helium was introduced at a concentration of $0.5 \%$ of the total air purge as an inert tracer gas so that total amounts of generated gas and peak generation rates could be calculated. This approach eliminates the impact of fugitive gas losses through small leaks on the calculated outlet gas flowrates. During the runs, the kettle was visually monitored to observe process behavior including foaming, air entrainment, rheology changes, loss of heat transfer capabilities, and off-gas carryover. Observations were recorded on data sheets and pasted into laboratory notebooks. ${ }^{11}$

Quality control measures were in place to qualify the data in this report. Helium and air purges were controlled using mass flow controllers calibrated by the SRNL Standards Lab using traceable standards and methods. Thermocouples were calibrated using a calibrated dry block calibrator. The 
GCs were calibrated with standard calibration gases before and after the runs and the data reprocessed based on these data. The $\mathrm{pH}$ probes were calibrated with $\mathrm{pH} 4$ and $\mathrm{pH} 10$ buffer solutions and rechecked at the conclusion of each run using $\mathrm{pH} 4,7$ and 10 buffer solutions.

The automated data acquisition system developed for the 4-L SRAT rigs was used to collect data electronically. Data included SRAT temperature, bath temperatures for the cooling water to the SRAT condenser and FAVC, slurry $\mathrm{pH}$, heating rod temperature and watts, SRAT mixer speed and torque, and air and helium purge flows. Cumulative acid addition flowrate and volume data are calculated from the acid pump rotation speed. Raw GC data were acquired on a computer dedicated to the GCs.

Dual column Agilent 3000A micro GC's were used on both runs. The GC's were baked out before and between runs. Column-A can collect data related to $\mathrm{He}, \mathrm{H}_{2}, \mathrm{O}_{2}, \mathrm{~N}_{2}, \mathrm{NO}$, and $\mathrm{CO}$, while column-B can collect data related to $\mathrm{CO}_{2}, \mathrm{~N}_{2} \mathrm{O}$, and water. Calibrations were performed using a standard calibration gas containing $0.499 \mathrm{vol} \% \mathrm{He}, 1.000 \mathrm{vol} \% \mathrm{H}_{2}, 20.00 \mathrm{vol} \% \mathrm{O}_{2}, 51.0 \mathrm{vol} \% \mathrm{~N}_{2}$, $25.0 \mathrm{vol} \% \mathrm{CO}_{2}$ and $2.50 \mathrm{vol} \% \mathrm{~N}_{2} \mathrm{O}$. Instrument calibration was verified prior to starting the SRAT cycle. Room air was used to give a two point calibration for $\mathrm{N}_{2}$. Calibration status was rechecked following the SRAT cycle.

Concentrated nitric acid ( $\sim 50 \mathrm{wt} \%)$ and glycolic acid ( $\sim 70 \mathrm{wt} \%)$ were used to acidify the sludge and perform neutralization and reduction reactions during processing. The total amount of acid (in moles) to add for each run was determined using the Koopman acid equation ${ }^{8}$. The Koopman minimum acid equation was used with a $100 \%$ stoichiometric factor for all tests except GF38 (125\%), GF40 (134\%) and GF41 (130\%).

The acid mix was partitioned between nitric and glycolic acid by utilizing the latest REDOX equation ${ }^{12}$ with a term added for glycolate ion (see below). A coefficient of 6 was used on the glycolate term based on electron equivalence. ${ }^{13}$ The REDOX target $\left(\mathrm{Fe}^{2+} / \Sigma \mathrm{Fe}\right)$ was 0.1 . Process assumptions were made to predict SME product anion concentrations. In addition to the standard assumptions needed for formate and oxalate loss and nitrite to nitrate conversion, a factor was added to the acid calculation for glycolate loss. Process assumptions for the stoichiometric window testing were adjusted based on results from earlier testing.

REDOX $=0.2358+0.1999 *\left(\left(2 * \mathrm{C}_{\text {formate }}+4 * \mathrm{C}_{\text {oxalate }}+4 * \mathrm{C}_{\text {Carbon }}+6 * \mathrm{C}_{\text {glycolate }}-5 *\left(\mathrm{C}_{\text {Nitrate }}+\mathrm{C}_{\text {Nitrite }}\right)-\right.\right.$ $\left.\left.5 * \mathrm{C}_{\mathrm{Mn}}\right)\right)^{*}(45 / \mathrm{TS})$

Where $\mathrm{C}_{\mathrm{x}}=$ species concentration of component $\mathrm{x}$, g-mole $/ \mathrm{kg}$ melter feed, $\mathrm{TS}=$ total solids in melter feed in wt $\%$, and REDOX is a molar ratio of $\mathrm{Fe}^{2+} / \Sigma \mathrm{Fe}$

A standard 4-L SRAT/SME apparatus with an ammonia scrubber was used for these simulations. The scrubber solution consisted of $749 \mathrm{~g}$ of de-ionized water and $1 \mathrm{~g}$ of $50 \mathrm{wt} \%$ nitric acid. The solution was recirculated through the column by a MasterFlex pump at $300 \mathrm{~mL} / \mathrm{min}$ through a spray nozzle at the top of the packed section. Glass rings were used as packing and did not significantly add to the back pressure on the SRAT vessel as has been seen in earlier tests with different packing. The SRAT condenser was maintained at $25^{\circ} \mathrm{C}$ during the run, while the vent condenser was maintained at $4^{\circ} \mathrm{C}$.

In the initial experiments with sludge simulants, $200 \mathrm{ppm}$ antifoam was added prior to acid addition, $100 \mathrm{ppm}$ was added after nitric acid addition, $500 \mathrm{ppm}$ was added before boiling and $100 \mathrm{ppm}$ was added before the SME cycle and every 12 hours during boiling. In later experiments the 200 and $500 \mathrm{ppm}$ antifoam additions were reduced to $100 \mathrm{ppm}$. 
SRNL-STI-2012-00018

Revision 1

In supernate experiments, no antifoam was added. SRAT processing was abbreviated to include a two hour dewater time and about three hours at reflux.

\subsection{Sludge Preparation}

SRNL produced four matrix sludge simulants in order to improve the understanding of how changing sludge composition impacts DWPF waste processing. These simulants have been used in other SRNL studies, and the composition has been previously measured. ${ }^{14}$ These simulants were used to demonstrate the flowsheet across a broad compositional range. In addition, two less washed simulants (1.6 and $1.9 \mathrm{M} \mathrm{Na}$ ) were produced to study the impact of less washing on CPC processing.

There are many elements in the insoluble solids. The two major insoluble elements in Savannah River Site (SRS) high activity waste slurries are iron and aluminum, corresponding to Plutonium URanium EXtraction (PUREX) and H-Canyon Modified (HM) wastes respectively. The first solids concentration parameter was chosen to reflect variations between these two elements. There are a number of elements that occur at about an order of magnitude lower concentration than $\mathrm{Al}$ and $\mathrm{Fe}$ in SRS waste slurries including $\mathrm{Ca}, \mathrm{Hg}, \mathrm{Mg}, \mathrm{Mn}, \mathrm{Ni}$, and $\mathrm{Si}$ (also $\mathrm{U}$, but that is outside the scope of this study). These can be defined as the semi-major elements. Creating high-low pairs from all of these elements in addition to $\mathrm{Al}$ and $\mathrm{Fe}$ would have led to a prohibitively large study. The size of the study was controlled by grouping some of the semi-major elements into two sets. Manganese was paired with $\mathrm{Ca}$, and $\mathrm{Mg}$ was paired with $\mathrm{Ni}$. This defined the second concentration parameter in the study. Silicon, as $\mathrm{SiO}_{2}$, was seen as essentially inert and not included in the pairings with the other semi-major elements.

Mercury has been studied in other contexts. Therefore, mercury was held at $1.5 \mathrm{wt} \%$ in the starting sludge total solids in all tests in the sludge matrix study. The noble metals were added at the same concentrations as were used in previous high noble metal tests of the matrix sludges. ${ }^{15} \mathrm{Cr}$ is typically at least an order of magnitude lower in concentration than the semi-major elements. It was considered potentially significant, however, due to its several oxidation states and was added to the Mg-Ni pair. Another constraint on handling the semi-major elements was that the oxides must sum to $100 \%$. Suppressing or enhancing the concentrations of all of the semi-major elements simultaneously would have led to unreasonably high or low concentrations of either $\mathrm{Al}$ or $\mathrm{Fe}$. Conceptually, the second concentration parameter represents reasonable compositional variations within each of the two main waste types, PUREX or HM (Figure 2-2). 


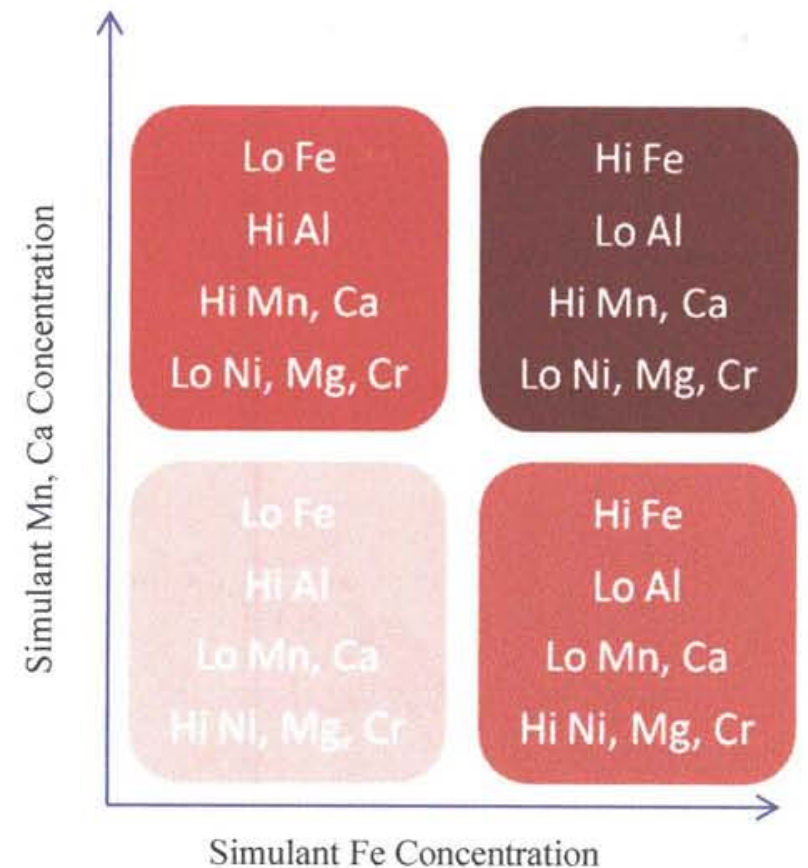

Figure 2-2. Definition of Sludge Matrix Simulants

The three primary parameter groups drawn from the insoluble solids are summarized below:

1. High iron or high aluminum (representing PUREX and HM wastes respectively). This parameter is referred to as either $\mathrm{Hi} \mathrm{Fe}$ or Lo $\mathrm{Fe}$ in the discussion below.

2. High $\mathrm{Mn}$ and $\mathrm{Ca}$ or high $\mathrm{Mg}, \mathrm{Ni}$, and $\mathrm{Cr}$ (representing the semi-major insoluble species). This parameter is referred to as either Hi Mn or Lo Mn below.

3. The other (minor) sludge species, such as $\mathrm{Ba}, \mathrm{Zn}, \mathrm{Zr}, \mathrm{Cu}, \mathrm{La}$, etc., were to be held in constant relative proportions in the simulants.

The measured slurry composition is summarized in Table 2-1. The supernate compositions of the matrix sludge simulants were maintained nearly constant.

The sludge simulations had identical mercury and noble metal targets, given in Table $2-2$ as wt $\%$ in the total solids of the trimmed slurry. The noble metals concentrations are comparable to the high noble metal case in the Rh-Ru-Hg matrix study, while mercury was held constant during this study at the midpoint value of the $\mathrm{Rh}-\mathrm{Ru}-\mathrm{Hg}$ matrix study. ${ }^{15}$ 
Table 2-1. Composition of Sludge Simulants

\begin{tabular}{|c|c|c|c|c|c|c|c|}
\hline Result & $\begin{array}{c}\text { GF34 } \\
\text { HiFeHiNn }\end{array}$ & $\begin{array}{l}\text { GF35 } \\
\text { SB7An }\end{array}$ & $\begin{array}{c}\text { GF36 } \\
\text { HiFeLoNn }\end{array}$ & $\begin{array}{c}\text { GF37/38 } \\
\text { LoFeL.oNn }\end{array}$ & $\begin{array}{c}\text { GF40 } \\
1.6 \mathrm{~N} \mathrm{Na}\end{array}$ & $\begin{array}{c}\text { GF41 } \\
1.9 \mathrm{M} \mathrm{Na}\end{array}$ & Enits \\
\hline Total Solids & 23.70 & 18.02 & 22.81 & 23.07 & 24.14 & 25.43 & $w t \%$ \\
\hline Calcined Solids & 17.81 & 13.61 & 16.95 & 16.00 & 17.01 & 17.85 & $w t \%$ \\
\hline Insoluble Solids & 16.70 & 12.57 & 16.35 & 16.05 & 16.51 & 16.97 & $w t \%$ \\
\hline Soluble Solids & 7.00 & 5.45 & 6.47 & 7.01 & 7.63 & 8.46 & wt $\%$ \\
\hline Slurry Density & 1.185 & 1.142 & 1.189 & 1.176 & 1.174 & 1.215 & $\mathrm{~kg} / \mathrm{L}$ slurry \\
\hline Filtrate Density & 1.057 & 1.053 & 1.055 & 1.057 & 1.076 & 1.091 & $\mathrm{~kg} / \mathrm{L}$ supernate \\
\hline Aluminum & 9.000 & 15.65 & 9.130 & 23.8 & 14.8 & 13.9 & wt $\%$ calcined basis \\
\hline Boron & $<0.100$ & $<0.100$ & $<0.100$ & $<0.100$ & NM & NM & wt $\%$ calcined basis \\
\hline Barium & 0.077 & 0.102 & 0.101 & 0.0705 & 0.085 & 0.0802 & wt $\%$ calcined basis \\
\hline Calcium & 3.83 & 0.836 & 2.22 & 1.97 & 0.565 & 0.288 & wt $\%$ calcined basis \\
\hline Cadmium & $<0.010$ & NM & $<0.010$ & $<0.010$ & NM & NM & wt $\%$ calcined basis \\
\hline Cerium & 0.104 & 0.148 & 0.108 & 0.0965 & NM & NM & wt $\%$ calcined basis \\
\hline Chromium & 0.015 & 0.0455 & 0.285 & 0.244 & 0.027 & 0.0260 & wt $\%$ calcined basis \\
\hline Copper & 0.045 & 0.033 & 0.045 & 0.048 & 0.040 & 0.0350 & wt $\%$ calcined basis \\
\hline Iron & 32.4 & 19.2 & 31.5 & 12.2 & 14.8 & 13.7 & wt $\%$ calcined basis \\
\hline Potassium & 0.120 & 0.125 & 0.0905 & 0.0955 & 0.369 & 0.392 & wt $\%$ calcined basis \\
\hline Magnesium & 0.396 & 0.366 & 2.69 & 2.42 & 0.317 & 0.302 & wt $\%$ calcined basis \\
\hline Manganese & 4.04 & 4.37 & 0.721 & 0.661 & 4.86 & 4.53 & wt $\%$ calcined basis \\
\hline Sodium & 12.9 & 15.3 & 13.1 & 14.2 & 22.8 & 24.4 & wt $\%$ calcined basis \\
\hline Nickel & 0.213 & 3.37 & 2.6345 & 2.31 & 2.10 & 1.95 & wt $\%$ calcined basis \\
\hline Phosphorus & $<0.100$ & $<0.100$ & $<0.100$ & $<0.100$ & 0.032 & $<0.010$ & wt $\%$ calcined basis \\
\hline Lead & 0.071 & 0.025 & 0.047 & 0.0715 & $<0.010$ & $<0.010$ & wt $\%$ calcined basis \\
\hline Sulfur & 0.289 & 0.371 & 0.340 & 0.374 & 0.276 & 0.333 & wt $\%$ calcined basis \\
\hline Silicon & 1.580 & 1.91 & 1.52 & 1.32 & 1.52 & 1.369 & wt $\%$ calcined basis \\
\hline Tin & $<0.010$ & 0.013 & 0.106 & 0.0925 & NM & NM & wt $\%$ calcined basis \\
\hline Titanium & $<0.010$ & 0.025 & $<0.010$ & $<0.010$ & 0.025 & 0.0230 & wt $\%$ calcined basis \\
\hline Zinc & 0.065 & 0.047 & 0.0775 & 0.0705 & 0.049 & 0.0452 & wt $\%$ calcined basis \\
\hline Zirconium & 0.054 & 0.252 & 0.1175 & 0.049 & 0.027 & 0.195 & wt $\%$ calcined basis \\
\hline Nitrite & 17,900 & 9,140 & 17,800 & 13,300 & 13,500 & 15,800 & $\mathrm{mg} / \mathrm{kg}$ slurry \\
\hline Nitrate & 13,550 & 6,470 & 13,400 & 13,300 & 7,895 & 9,940 & $\mathrm{mg} / \mathrm{kg}$ slurry \\
\hline Formate & $<100$ & $<100$ & $<100$ & $<100$ & $<100$ & $<100$ & $\mathrm{mg} / \mathrm{kg}$ slurry \\
\hline Sulfate & 1,770 & 1,460 & 1,575 & 1,590 & 1,980 & 2,610 & $\mathrm{mg} / \mathrm{kg}$ slurry \\
\hline Chlorine & 116 & $<100$ & 131 & 127 & $<100$ & $<100$ & $\mathrm{mg} / \mathrm{kg}$ slurry \\
\hline Phosphate & 0 & $<100$ & $<100$ & $<100$ & $<100$ & $<100$ & $\mathrm{mg} / \mathrm{kg}$ slurry \\
\hline Oxalate & 300 & 8,500 & 275 & 295 & 18,750 & 20,000 & mg/kg slurry \\
\hline Glycolate & $<100$ & NM & $<100$ & $<100$ & $<100$ & $<100$ & $\mathrm{mg} / \mathrm{kg}$ slurry \\
\hline Slurry TIC & 2,751 & 1,066 & 2,492 & 2,400 & 1,840 & 1,730 & $\mathrm{mg} / \mathrm{kg}$ slurry \\
\hline Supernate TIC & 1,080 & 664 & 1,310 & 1,280 & 1,790 & 1760 & $\mathrm{mg} / \mathrm{L}$ supernate \\
\hline Total Base pH 7 & 0.590 & 0.580 & 0.562 & 0.522 & 0.838 & 0.879 & moles $/ \mathrm{L}$ \\
\hline
\end{tabular}


Table 2-2. Mercury and Noble Metal Composition Added to Sludge Simulants, wt\% Total Solids Basis

\begin{tabular}{|lcc|}
\hline $\begin{array}{l}\text { Noble } \\
\text { Metal }\end{array}$ & Runs GF34-GF38 & GF40-41 \\
\hline Target Hg & 1.5000 & 1.500 \\
\hline Target Ag & 0.0014 & 0.0144 \\
\hline Target Pd & 0.0790 & 0.0033 \\
\hline Target Rh & 0.0380 & 0.0192 \\
\hline Target Ru & 0.2170 & 0.0877 \\
\hline
\end{tabular}

An additional supernate simulant was prepared to supplement the four slurry simulants above. The purpose of this simpler simulant was to improve understanding of the mercury reduction chemistry. The simulant was similar to the supernate used in the matrix slurry preparation. The only soluble species added were sodium hydroxide, sodium nitrite, sodium nitrate, sodium sulfate, sodium oxalate, sodium carbonate and potassium nitrate. The resulting concentration is summarized in Table 2-3. The added noble metal and mercury target of these runs is summarized in Table 2-4. Note that because of the lower total solids of the supernate, the added mass of noble metals and mercury is approximately one-third that added in the slurry experiments.

Table 2-3. Composition of Supernate Simulant

\begin{tabular}{|lcc|}
\hline Anion or Cation & GF39a-d & GF39e \\
\hline Nitrite, $\mathbf{~ m g / k g}$ & 21,561 & 0 \\
\hline Nitrate, $\mathbf{m g} / \mathbf{k g}$ & 15,784 & 16,311 \\
\hline Carbonate, $\mathbf{~ m g / k g}$ & 6,051 & 6,253 \\
\hline Oxalate, $\mathbf{~ m g} / \mathbf{k g}$ & 351 & 363 \\
\hline Sulfate, $\mathbf{m g} / \mathbf{k g}$ & 1,888 & 1,951 \\
\hline Free $\mathbf{H y d r o x i d e}, \mathbf{M}$ & $3,556(0.221 \mathrm{M})$ & 0.221 \\
\hline Na, $\mathbf{m g} / \mathbf{k g}$ & 27,067 & 27,067 \\
\hline $\mathbf{K}, \mathbf{m g} / \mathbf{k g}$ & 153 & 153 \\
\hline
\end{tabular}

Table 2-4. Mercury and Noble Metal Composition Added to Supernate Simulants, wt \% Total Solids Basis

\begin{tabular}{|lccccc|}
\hline Noble Metal & GF39a & GF39b & GF39c & GF39d & GF39e \\
\hline Target $\mathbf{H g}$ & 1.5000 & 1.5000 & 1.5000 & 1.5000 & 2.5717 \\
\hline Target $\mathbf{A g}$ & 0.0000 & 0.0014 & 0.0014 & 0.0014 & 0.0000 \\
\hline Target Pd & 0.0000 & 0.0790 & 0.0790 & 0.0790 & 0.0000 \\
\hline Target $\mathbf{R h}$ & 0.0000 & 0.0297 & 0.0297 & 0.0297 & 0.0000 \\
\hline Target $\mathbf{R u}$ & 0.0000 & 0.2170 & 0.0000 & 0.2170 & 0.0000 \\
\hline
\end{tabular}

\section{$2.3 \underline{\text { CPC Run Details }}$}

The twelve nitric-glycolic acid flowsheet tests with slurry and five tests with supernate were performed at the ACTL using the four-liter kettle setup. Table 2-5 identifies each run and its corresponding assumptions. 
Table 2-5. CPC Simulation Process Assumptions

\begin{tabular}{ccccccc}
\hline Run & Sludge & Cycles & Date & $\begin{array}{c}\text { \% Koopman } \\
\text { Acid } \\
\text { Stoichiometry }\end{array}$ & $\begin{array}{c}\text { \% Hsu Acid } \\
\text { Stoichiometry }\end{array}$ & Labware \\
GF34 & HiFeHiMn & SRAT/SME & 16-Nov-11 & 104.0 & 108.0 & New \\
GF34b & HiFeHiMn & SRAT/SME & 16-Nov-11 & 104.0 & 108.0 & New \\
GF34c & HiFeHiMn & SRAT/SME & 16-Nov-11 & 104.0 & 108.0 & New \\
GF35 & SB7A & SRAT/SME & 17-Nov-11 & 100.0 & 102.2 & New \\
GF36 & HiFeLoMn & SRAT/SME & 16-Nov-11 & 106.1 & 125.1 & New \\
GF36b & HiFeLoMn & SRAT & 25-Jan-12 & 106.1 & 125.1 & New \\
GF36c & HiFeLoMn & SRAT & 25-Jan-12 & 106.1 & 125.1 & Old \\
GF37 & LoFeLoMn & SRAT/SME & 2-Feb-12 & 100.0 & 112.3 & New \\
GF37b & LoFeLoMn & SRAT & 17-Nov-11 & 100.0 & 112.3 & New \\
GF38 & LoFeLoMn & SRAT & 2-Feb-12 & 125.0 & 140.4 & New \\
GF39A & Supernate & SRAT & 22-Feb-12 & 100.0 & 73.9 & New \\
GF39B & Supernate & SRAT & 22-Feb-12 & 100.0 & 73.9 & New \\
GF39C & Supernate & SRAT & 29-Feb-12 & 100.0 & 73.9 & New \\
GF39D & Supernate & SRAT & 29-Feb-12 & 80.0 & 59.1 & New \\
GF39E & No Nitrite & SRAT & 8-May-12 & 100.0 & 73.4 & New \\
& Supernate & SRAT & 24-May-12 & 133.9 & 133.1 & New \\
GF40 & 1.6M Na & SRAT & 24-May-12 & 130.0 & 131.1 & New \\
GF41 & 1.9 M Na & SRAT & & & &
\end{tabular}

DWPF design basis processing conditions were scaled down and used for most processing parameters including SRAT/SME air purges and boil-up rate. SRAT product total dried solids were targeted at $27 \mathrm{wt} \%$ for the slurry simulant runs. Final SME total dried solids were targeted at $45 \%$ at $36 \%$ waste loading.

Because nitric and glycolic acid are more dilute acids than formic acid, both acids were added at the same molar flowrate as formic acid. Thus nitric acid was added at a DWPF scaled flowrate of 4.572 gallons per minute and glycolic acid was added at a DWPF scaled flowrate of 3.948 gallons per minute to maintain acid addition times. It is recommended that DWPF modify the acid feed pumps to deliver the higher flow rates before implementing the glycolic flowsheet.

The following constraints must be met by the current DWPF CPC flowsheet:

- SRAT hydrogen $<0.65 \mathrm{lb} / \mathrm{hr}$

- SME hydrogen $<0.223 \mathrm{lb} / \mathrm{hr}$

- Reduce mercury to elemental form

- Steam strip mercury below $0.8 \mathrm{wt} \%$ in the SRAT product dried solids

- SRAT product less than $1000 \mathrm{mg}$ nitrite/kg product slurry

- SRAT product rheology design basis 1.5 to 5 Pa yield stress and 5 to $12 \mathrm{cP}$ consistency

- SME product rheology 2.5 to 15 Pa yield stress and 10 to $40 \mathrm{cP}$ consistency

- Glass REDOX of $0.09-0.33 \mathrm{Fe}^{2+} / \Sigma \mathrm{Fe}$

- Minimize water in SME product ( $55 \mathrm{wt} \%$ typical)

- Minimal foaming

\footnotetext{
'Processing limits are the same for both SRAT and SME as agitator and drive are identical
} 
Twelve to fifteen samples were taken during each SRAT cycle to monitor the progress of the main chemical reactions. Major cations and anions were checked immediately after acid addition. Samples were taken during boiling to monitor suspended and dissolved mercury in the SRAT slurry. These samples were transferred directly into digestion vials to eliminate potential segregation of mercury during sub-sampling/aliquoting steps. The SRAT and SME product slurries were sampled similarly once they had cooled to $90^{\circ} \mathrm{C}$ while the vessel contents were still mixing.

Additional SRAT product samples were taken for compositional and solids analyses after the product had cooled further. The MWWT and FAVC were drained and the condensates weighed after both the SRAT and SME cycles. Elemental mercury was separated from the aqueous phase in the post-SRAT MWWT sample, and the mass of the mercury-rich material determined. Beads of elemental mercury were also recovered from a few of the SME dewatering condensates and weighed (depending on how big or numerous the bead(s) appeared to be).

Data are presented in Section 3 showing how the nitric-glycolic flowsheet met or exceeded the processing constraints in the list above with the possible exception of mercury removal and REDOX.

\subsection{Analytical Methods}

Process samples were analyzed by various methods. Slurry and supernate elemental compositions were measured by inductively coupled plasma-atomic emission spectroscopy (ICP-AES) at PSAL. Soluble anion concentrations were measured by IC. Mercury concentration was measured by ICPAES. Ammonium ion concentration on selected samples was measured by cation chromatography by SRNL AD. Slurry and supernate densities were measured using an Anton-Parr instrument at PSAL. Dewater and condensate samples were submitted to PSAL for IC. A gradient method using the Dionex AG-11HC and AS-11 HC, $2 \mathrm{~mm}$ microbore columns was used to analyze fluoride, glycolate, formate, chloride, nitrite, nitrate, sulfate, oxalate and phosphate on SRAT/SME samples. ${ }^{16}$

SME product samples were vitrified in nepheline sealed crucibles, and the resulting glasses were measured for REDOX $\left(\mathrm{Fe}^{2+} / \Sigma \mathrm{Fe}\right){ }^{17}$ The REDOX target for all the simulations in this study was 0.1 . The target is achieved by predicting the SME product anion concentrations and adjusting the split of acids between nitric and glycolic. Therefore the ability to control REDOX at the target value is highly dependent on being able to accurately predict anion behavior in the SRAT and SME cycles. Inserting the actual SME product data into the latest REDOX correlation gave a "predicted" REDOX that was different than the target. It should be noted that frit 418 was used for all runs. No attempt was made to produce a frit that was optimized for each of the four sludges. The glass produced was nonhomogeneous and this likely impacted the redox results.

Agilent $^{\text {( }} 3000 \mathrm{~A}$ micro GC's were used for all runs. The GC's were baked out before and between runs. Column-A can collect data related to $\mathrm{He}, \mathrm{H}_{2}, \mathrm{O}_{2}, \mathrm{~N}_{2}, \mathrm{NO}$, and $\mathrm{CO}$, while column-B can collect data related to $\mathrm{CO}_{2}, \mathrm{~N}_{2} \mathrm{O}$, and water. GC's were calibrated with a standard calibration gas containing $0.510 \mathrm{vol} \% \mathrm{He}, 1.000 \mathrm{vol} \% \mathrm{H}_{2}, 20.10 \mathrm{vol} \% \mathrm{O}_{2}, 50.77 \mathrm{vol} \% \mathrm{~N}_{2}, 25.1 \mathrm{vol} \% \mathrm{CO}_{2}$ and 2.52 vol $\% \mathrm{~N}_{2} \mathrm{O}$. The calibration was verified prior to starting the SRAT cycle and after completing the SME cycle. Room air was used to give a two point calibration for $\mathrm{N}_{2}$. No evidence for $\mathrm{CO}$ generation was obtained while examining the region of the chromatogram where it would elute. The chilled off-gas leaving the FAVC was passed through a Nafion ${ }^{\star}$ dryer in counter-current flow with a dried air stream to reduce the moisture content at the GC inlet. The dried, chilled off-gas stream was sampled by a GC from the beginning of heat-up to temperature to start the SRAT cycle through most of the cool down following the SME cycle. 
Gas chromatograph off-gas data were scaled to DWPF flow rates. The calculation methodology has been previously documented. ${ }^{18}$ An internal standard flow is usually established with helium. Other gas flow rates are determined relative to helium by taking the ratio of the two gas volume percentages times the helium standard flow. The result is scaled by the ratio of 6,000 gallons of fresh sludge divided by the volume of fresh sludge in the simulant SRAT charge.

Two new instruments were used in the last four slurry-fed sludge runs. An Extrel $^{\circledR}$ MAX300LG Mass Spectrometer (MS) was used in runs GF34b, GF34c, GF40 and GF41. In addition, an MKS MG2030 Fourier Transform InfraRed (FTIR) Analyzer was used during runs GF40 and GF41.

The Extrel ${ }^{\infty}$ MS was used to alternate between measuring the gas composition of both experiments. The MS uses a multiport switching valve to select the sample stream. The samples were pulled through the MS using a single diaphragm sample pump on the outlet of the MS sampling port. When not being sampled by the MS, the other sample stream still flowed continuously through a bypass port so the sample would always be fresh. The two sample streams were alternately analyzed for approximately 2.87 minutes with a 30 second delay during switching to purge out the previous sample stream. The MS was calibrated with a series of calibration gases as described in the next paragraph. The MS measured the composition of the sample approximately every 7 seconds (or 24 sample results during the 2.87 minute period).

Process mass spectrometry measures the intensity of ion signals and converts these signals to concentrations using the calibration data. Because some gases have interfering ions (e.g., $\mathrm{N}_{2}$ is measured at mass/charge $(\mathrm{m} / \mathrm{z})$ of $28\left(\mathrm{~N}_{2}{ }^{+}\right) ; \mathrm{CO}_{2}$ is measured at $\mathrm{m} / \mathrm{z} 44$, and has an interfering ion fragment at $\mathrm{m} / \mathrm{z}$ of 28 from $\mathrm{CO}^{+}$that must be subtracted from the total signal at $\mathrm{m} / \mathrm{z} 28$ to give the correct signal for $\mathrm{N}_{2}$. This 'fragment' calibration is done using a calibration gas, in this case $\mathrm{CO}_{2}$ in Ar. The gases $\mathrm{NO}_{2}, \mathrm{NO}, \mathrm{N}_{2} \mathrm{O}$, and $\mathrm{CO}_{2}$ all have fragments that interfere at other $\mathrm{m} / \mathrm{z}$ values. The signals are calibrated with calibration gases; the calibration factors determined are termed "sensitivity". Background signals at each measurement $\mathrm{m} / \mathrm{z}$ were measured in pure $\mathrm{N}_{2}$ and $\mathrm{Ar}$. The calibration gases used are summarized in Table 2-6.

Table 2-6. Mass Spectrometer Calibration Gases

\begin{tabular}{|c|c|}
\hline Gas & Purpose \\
\hline Ar & background signals at $\mathrm{m} / \mathrm{z} 28 \& 30$ \\
\hline $\mathbf{N}_{2}$ & background signals at $\mathrm{m} / \mathrm{z} 2,4,32,40,44,46$ \\
\hline $20 \% \mathrm{CO}_{2}$ in $\mathrm{Ar}$ & $\mathrm{CO}_{2}$ fragment at $\mathrm{m} / \mathrm{z} 28$ \\
\hline $5 \% \mathrm{NO}_{2}$ in $\mathrm{N}_{2}+\mathrm{O}_{2}$ & $\mathrm{NO}_{2}$ fragment at $\mathrm{m} / \mathrm{z} 30$, calibration for $\mathrm{NO}_{2} \mathrm{~m} / \mathrm{z} 46$ \\
\hline $\begin{array}{r}2 \% \mathrm{H}_{2}, 1 \% \mathrm{He}, 20 \% \mathrm{O}_{2} \\
10 \% \mathrm{CO}_{2}, 1 \% \mathrm{Ar}, 66 \% \mathrm{~N}_{2}\end{array}$ & $\begin{array}{l}\text { calibration of each gas }(\mathrm{m} / \mathrm{z} 2,4,32,44,40 \text {, } \\
\text { respectively); } \mathrm{N}_{2} \text { sensitivity }=1.000 \text { by definition) }\end{array}$ \\
\hline $2 \% \mathrm{NO}$ in $\mathrm{Ar}$ & calibration for $\mathrm{NO}$ at $\mathrm{m} / \mathrm{z} 30$ \\
\hline
\end{tabular}

The presence of $\mathrm{N}_{2} \mathrm{O}$ in the process gas introduces error in the measurements of $\mathrm{CO}_{2}, \mathrm{NO}$, and $\mathrm{N}_{2}$ because it has fragments with $\mathrm{m} / \mathrm{z}$ at the measurement masses of each of these gases. The MS cannot be calibrated for $\mathrm{N}_{2} \mathrm{O}$ because the relative amount of $\mathrm{N}_{2} \mathrm{O}$ to the other gases is too small to give a reliable calibration. The presence of $1.2 \% \mathrm{~N}_{2} \mathrm{O}$ (the highest measured by $\mathrm{GC}$ ) would result in the measurement of $\mathrm{N}_{2}$ being high by about $0.12 \%$, NO being high by about $0.24 \%$, and $\mathrm{CO}_{2}$ being high by about $0.86 \%$. 
About twice per hour, the MS was set to scan the mass spectrum from 48 to 250 to detect any larger species. The purpose of this was to search of components that weren't being measured by the GCs. The ion $\mathrm{CF}_{3}{ }^{+}$was consistently found, but this was due to the turbomolecular pump seal oil. The presence of hexamethyldisiloxane (HMDSO) was seen in several of the mass spectra. No other species were detected.

The FTIR was used to measure the gas composition of one of the two SRAT rigs during each concurrent run. The sample location was the same as used for the GC and MS. The FTIR uses factory calibration data for the infrared spectra and does not need to be calibrated; it automatically adjusts for changes in signal strength. The gases measured by the FTIR were $\mathrm{CO}_{2}, \mathrm{~N}_{2} \mathrm{O}, \mathrm{NO}, \mathrm{NO}_{2}$, and HMDSO. It also had the ability to detect $\mathrm{CO}, \mathrm{NH}_{3}$, nitric acid, formic acid, and water, but no significant amounts were detected. Low ppm amounts of nitric and formic acids were detected during nitric and glycolic acid additions, but these values may have been due to interferences.

In general, the FTIR values matched the GC and MS values reasonably well. Note that the concentrations in the process for $\mathrm{NO}, \mathrm{NO}_{2}$, and $\mathrm{CO}_{2}$ significantly exceeded the calibration data, so the FTIR values are extrapolations of the calibration curves. The raw spectral data will be analyzed for the presence of species not in the calibration library at a future date. Antifoam breakdown products such as trimethylsilanol and siloxanes larger than six carbons are possible species that could be found from the spectra by further analysis.

\subsection{Results and Discussion}

Four SRAT simulations with supernate and eight SRAT/SME process simulations with slurry feeds were completed to demonstrate the feasibility of using only glycolic acid as the reducing acid in SRAT processing. The elimination of formic acid has the potential to eliminate the catalytic generation of hydrogen, which could lead to the reduction of the air purge in the DWPF CPC. The main concern in eliminating formic acid is that the mercury won't be effectively reduced, and won't be removed by steam stripping to meet the DWPF SRAT mercury target and minimize the mercury sent to the melter. The discussion begins with the supernate results followed by the slurry results.

\subsection{Supernate Testing}

Four SRAT process simulations were completed with a simple supernate solution with added mercury and noble metals. A fifth run was completed with a nitrite free supernate solution to determine whether nitrite is needed to reduce mercury. These runs were performed after the slurry runs in order to better understand the processing chemistry. In particular, it was important to understand when the mercury is reduced in processing. Samples were pulled during glycolic acid addition and for several hours during the dewater and reflux phases to better understand the process chemistry using a simpler mixture than sludge simulants.

\subsubsection{Mercury Reduction and Stripping}

Approximately $3.4 \mathrm{~g}$ of mercury were added to each simulation. The mercury recovery results are summarized in Table 3-1. 
Table 3-1. Supernate Testing with Mercury and Noble Metals

\begin{tabular}{|l|c|c|c|c|c|}
\hline Run & GF39a & GF39b & GF39c & GF39d & GF39e \\
\cline { 2 - 6 } Hg, wt \% & 1.5 & 1.5 & 1.5 & 1.5 & 1.5 \\
\hline Rh, wt \% & 0 & 0.0297 & 0.0297 & 0.0297 & 0 \\
\hline Pd, wt \% & 0 & 0.079 & 0.079 & 0.079 & 0 \\
\hline $\begin{array}{l}\text { Ag, wt \% } \\
\text { Ru, wt \% }\end{array}$ & 0 & 0.0014 & 0.0014 & 0.0014 & 0 \\
\hline \% Koopman Acid Stoichiometry & 0 & 0.3358 & 0 & 0.3358 & 0 \\
\hline \% Hsu Acid Stoichiometry & 100 & 100 & 100 & 80 & 100 \\
\hline Hg Collected, g & 74 & 74 & 74 & 60 & 58 \\
\hline
\end{tabular}

* Found $1.455 \mathrm{~g}$ of elemental $\mathrm{Hg}$ in kettle

\#Found $1.939 \mathrm{~g}$ of black solids in kettle

The runs demonstrated that the mercury could be reduced and stripped with only glycolic acid (no formic acid). The exception to this is that in the runs with added ruthenium chloride (GF39b, GF39d), no mercury was recovered. Based on the obvious color changes (see photos below), the mercury was likely reduced in all the supernate runs. In runs with added ruthenium, $0.765 \mathrm{~g} \mathrm{Ru}$ was added as $\mathrm{RuCl}_{3} \cdot 1.93 \mathrm{H}_{2} \mathrm{O}$ (1.832 $\mathrm{g}$ or $0.0227 \mathrm{~g}$-moles of $\mathrm{Cl}$ ). In all runs, $3.689 \mathrm{~g}$ of $\mathrm{HgO}$ were added $(0.0170 \mathrm{~g}$-moles of $\mathrm{Hg}$ ). In previous testing, the presence of $\mathrm{Cl}$ led to the production of calomel $\left(\mathrm{Hg}_{2} \mathrm{Cl}_{2}\right)$, which is not steam stripped. It is recommended that these runs should be repeated with another form of $\mathrm{Ru}$ such as ruthenium oxide hydrate to see if adding the $\mathrm{Ru}$ without $\mathrm{Cl}$ has the same impact on mercury stripping.

The mercury (II) contained in the starting slurry as mercuric oxide was reduced during the glycolic acid addition at a $\mathrm{pH}$ of approximately 4.5 . The photographs below (Figure 3-1) show the slurry both before and after the run from Run GF39a (mercury was added but no noble metals). The kettle contents quickly changed from the orange $\mathrm{HgO}$ slurry to a transparent silver colored solution over a period of several minutes. The silver color slowly disappeared during boiling when the mercury was being steam stripped and recovered in the MWWT. 


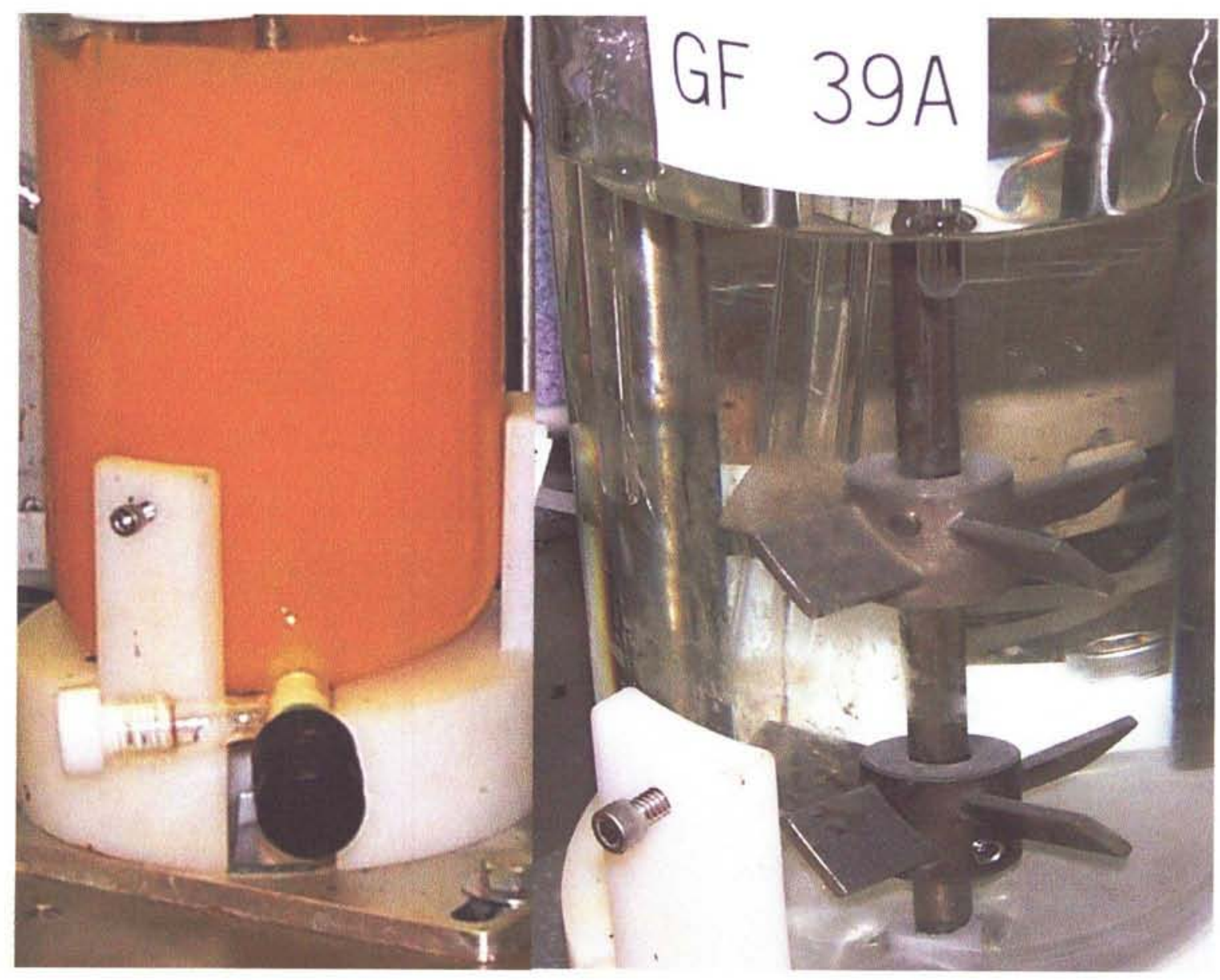

Figure 3-1. Photographs of GF39a before and after SRAT cycle (Supernate plus HgO)

In the runs with added noble metals and mercury, the slurry looked very much like sludge. The photographs below (Figure 3-2) show the slurry both before and after the run from Run GF39b (mercury and noble metals were added). The kettle contents quickly changed from the brown slurry to a transparent brown colored solution over a period of several minutes at a $\mathrm{pH}$ of 4.3 . No mercury was recovered in the MWWT. 

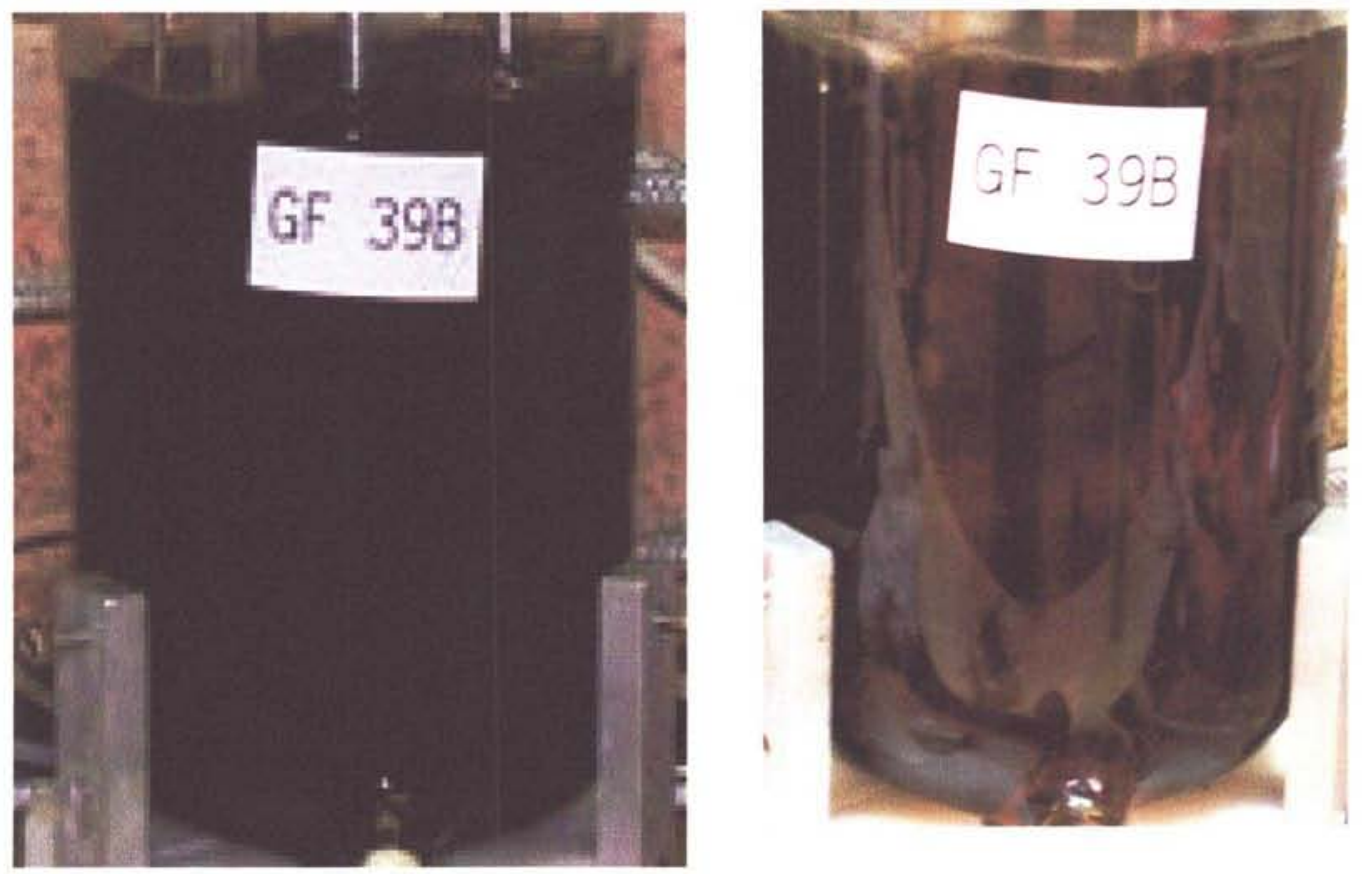

Figure 3-2. Photographs of GF39b before and after SRAT cycle (Supernate plus HgO and noble metals)

A mass balance was performed for each run to predict the concentration of all cations and anions throughout the run. In run GF39b (100\% Koopman Stoichiometry, added noble metals and mercury), there was an apparent mass loss of $986 \mathrm{~g}$ (expected mass loss $151 \mathrm{~g}$ ). This was calculated to match the final sodium concentration measured in the SRAT product sample. Using this mass loss, the predicted mercury concentration in the SRAT product is $2,306 \mathrm{mg} / \mathrm{L}$ and the measured mercury concentration was $2,315 \mathrm{mg} / \mathrm{L}$. In other words, the mercury was completely soluble in the SRAT product and no mercury was recovered (not reduced, not stripped) in the MWWT. In contrast, run GF39a (100\% Koopman stoichiometry, add mercury only), the final mercury concentration in the SRAT product was $14.9 \mathrm{mg} / \mathrm{L}$ compared to a predicted concentration of 1,433 $\mathrm{mg} / \mathrm{L}$ ( $1.04 \%$ of the mercury was soluble). In addition, of the $3.4 \mathrm{~g}$ of mercury added initially on an elemental basis, $0.6 \mathrm{~g}$ was collected in the MWWT and $1.5 \mathrm{~g}$ was found in the SRAT product slurry as elemental mercury.

\subsubsection{Nitrite and Carbonate Destruction}

Nitrite and carbonate were below detection limits by the first hour of reflux in supernate testing. The results are summarized in Table 3-2. 
Table 3-2. Nitrite Data, mg/L

\begin{tabular}{|lccccc|}
\hline Anion & GF39a & GF39b & GF39c & GF39d & GF39e \\
\hline Post Nitric Acid & 20,000 & 19,700 & 21,800 & 21,700 & $<500$ \\
\hline Mid Glycolic Acid & 10,800 & 6,560 & 4,540 & 11,700 & $<500$ \\
\hline Post Glycolic Acid & $<100$ & 1,070 & 1,150 & 2,615 & $<500$ \\
\hline 1 hour dewater & $<100$ & $<100$ & $<100$ & 224 & $<500$ \\
\hline Post Dewater & $<100$ & $<100$ & $<100$ & $<100$ & $<500$ \\
\hline Post Run & $<100$ & $<100$ & $<100$ & $<100$ & $<500$ \\
\hline
\end{tabular}

\subsubsection{Anion and Cation Mass Balance}

Anions and cations were measured (solid lines in graphs below) throughout the supernate runs. A mass balance was completed for each run based on the known amounts added in preparing the supernate and the mass of added noble metals and mercury. These predictions (dotted lines), calculated by mass balance, were plotted along with the measured result in Figure 3-3 and Figure 3-4 (GF39b is presented as an example of this data). It should be noted that the PSAL measured nitrate agrees well with the nitrate prediction and the PSAL measured glycolate is approximately $20 \%$ higher than the prediction. In addition, oxalate is also much higher than predicted. It is likely that some oxalate is produced from glycolate decomposition. The measured nitrate is greater than predicted during glycolic acid addition due to the oxidation of nitrite to nitrate but is lower than predicted during reflux and boiling due to nitrate destruction. The sulfate concentration as measured by IC was very different than predicted. However, the measured sulfate, as calculated from ICP-AES S, was approximately $30 \%$ higher than predicted.

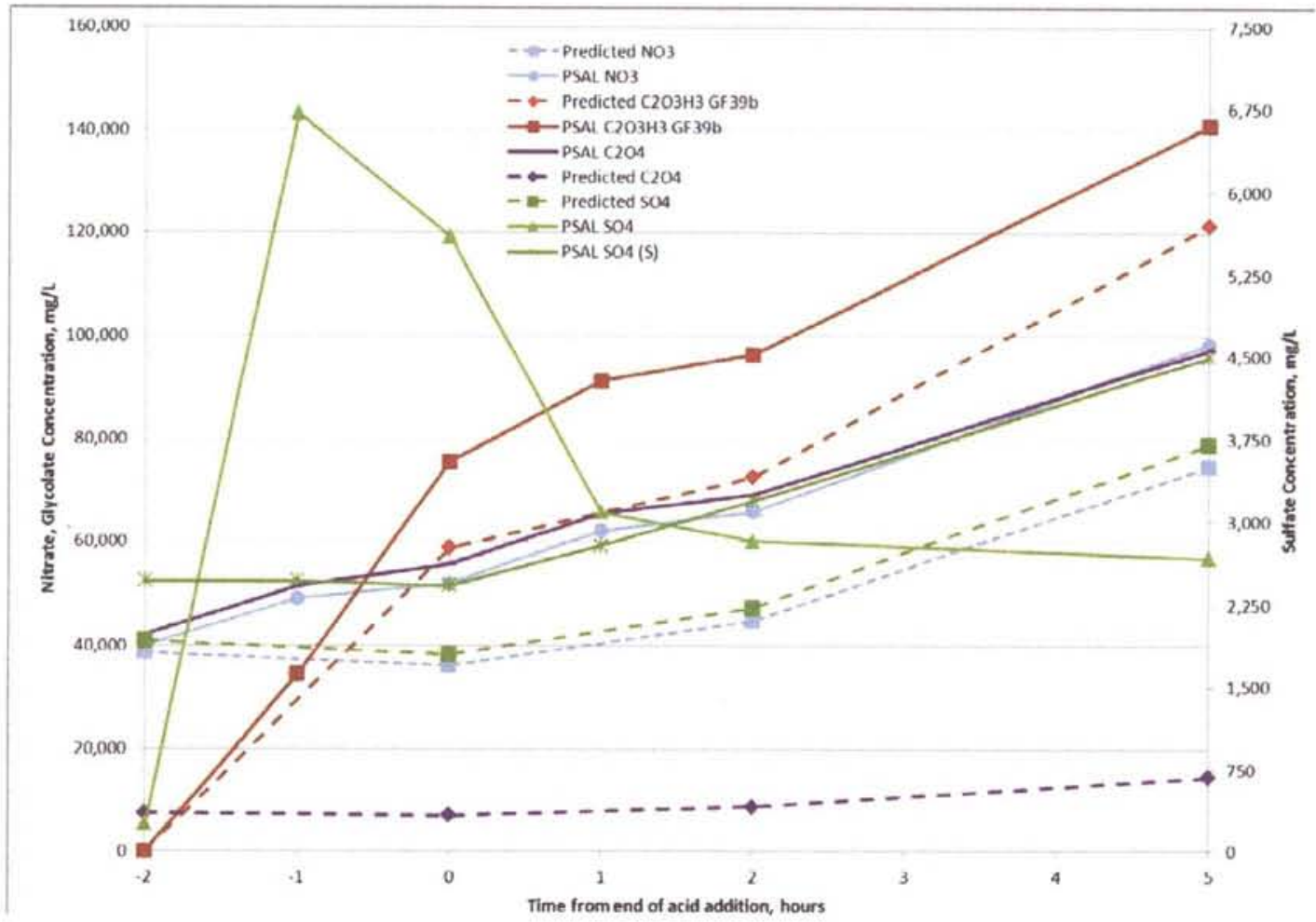

Figure 3-3. Supernate Run GF39b Predicted and Measured Anion Concentration 


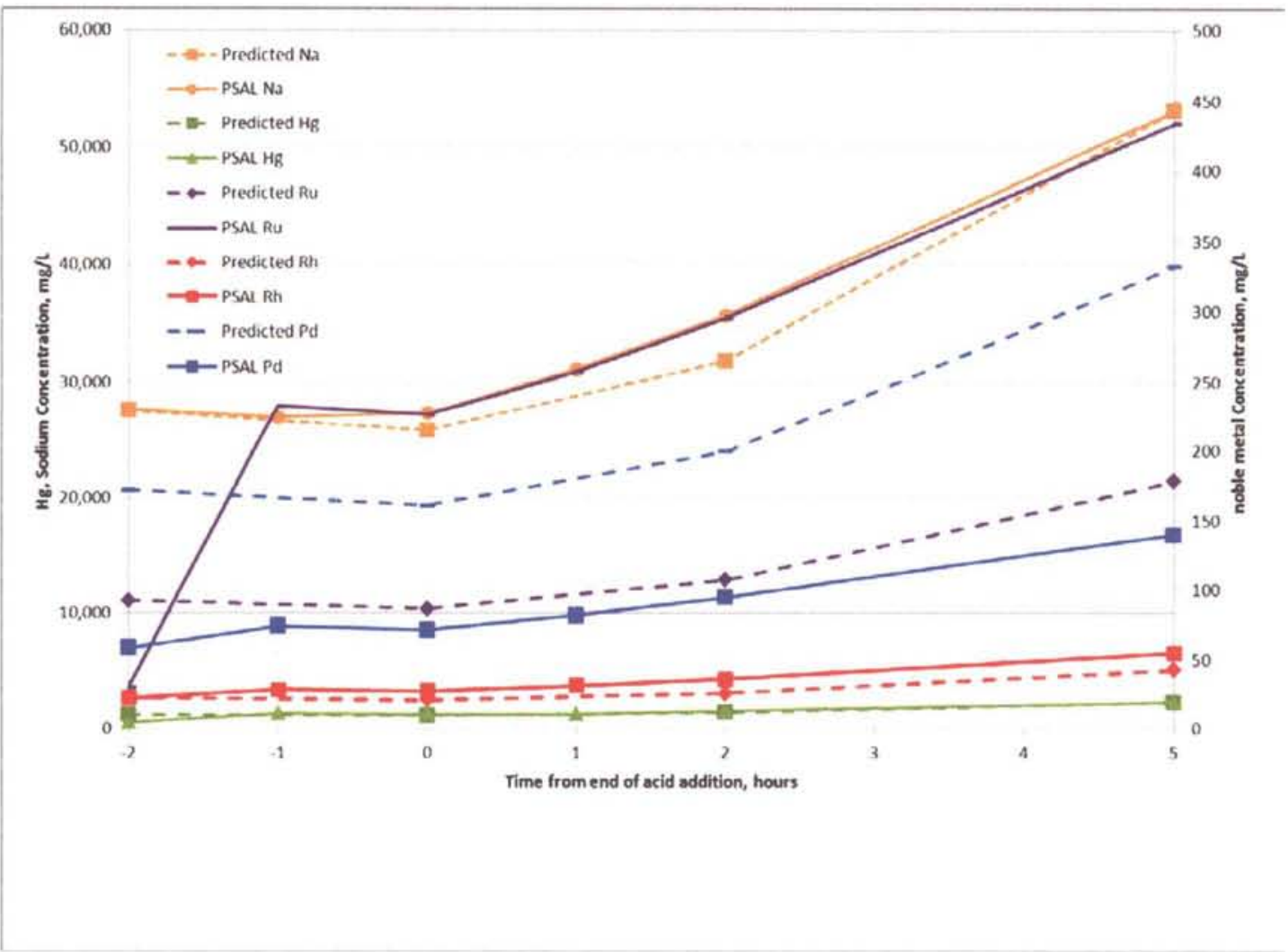

Figure 3-4. Supernate Run GF39b Predicted and Measured Cation Concentration

The measured sodium and mercury concentrations agreed well with predictions throughout run GF39b. The concentration of Pd and Ru were higher than predicted in Run GF39b. The Rh was approximately $80 \%$ of the predicted value and the $\mathrm{Ag}$ was below the detection limit. In Run GF39a (no added noble metals), the noble metals were all below detection limits.

\subsubsection{Nitrite-free Supernate Test}

One question that has always bothered our research team is whether glycolic acid is able to reduce mercury, allowing the elemental mercury to be removed by steam stripping. One theory was that glycolic acid needed a more reducing form such as glyoxylic acid to reduce the mercury. Glyoxylic acid, a better reducing agent than glycolic acid, could be produced by the reduction of glycolic acid by nitrite. As a result, a run was completed with a nitrite free simulant. This run was noble metal free, only mercury was added to the supernate. The result was that the mercury was completely reduced, a virtual duplication of Run GF39a. It appears that glycolic acid is fully capable of reducing mercury with or without nitrite present.

\subsubsection{Conclusions from Supernate Testing}

The new SRAT apparatus is capable of keeping the noble metals and mercury suspended prior to acid addition. In runs with all noble metals (GF39b, GF39d), no mercury was reduced or collected. In runs without ruthenium chloride (GF39a, GF39c, GF39e), mercury was collected in the MWWT and mercury was found in the SRAT product as an insoluble mercury compound. Run GF39e demonstrated that mercury could be reduced with or without nitrite present. 
The concentrations of $\mathrm{Pd}$ and $\mathrm{Ru}$ were higher than predicted in Run GF39b. The $\mathrm{Rh}$ was approximately $80 \%$ of predicted and the $\mathrm{Ag}$ was below the detection limit. In Run GF39a (no added noble metals), the noble metals were all below detection limits.

Another interesting observation is that although the runs had no added $\mathrm{Al}, \mathrm{Ca}, \mathrm{Cu}, \mathrm{Fe}, \mathrm{Mn}, \mathrm{Mg}, \mathrm{Ni}$ or $\mathrm{Si}$, these compounds were detected in samples throughout the runs (most of these have concentrations of approximately $10 \mathrm{mg} / \mathrm{L}$, although Si was $40-80 \mathrm{mg} / \mathrm{L}$ ). Although the glassware and agitator is cleaned by soaking in $8 \mathrm{M}$ nitric acid overnight, the runs cleaned the equipment by dissolving these metals. This is further demonstration that the glycolic-nitric flowsheet will help to keep the DWPF processing vessels cleaner than the current flowsheet.

\subsection{Slurry Testing}

Twelve SRAT and six SME process simulations were completed to demonstrate the Glycolic-Nitric Flowsheet. Ten SRAT and four SME process simulations utilized the matrix sludges with added mercury and noble metals. Runs GF34, GF35, GF36 and GF37 were completed first and also included SME cycles. Runs $36 \mathrm{~b}$ and $36 \mathrm{c}$ were duplicates of the GF36 SRAT cycle to compare the old and new processing rigs and determine whether the changes had impacted process chemistry. Run $37 \mathrm{~b}$ was a duplicate of GF37 and GF38 was a higher acid stoichiometry repeat of GF37. The main reason for the four repeat runs was to better track mercury as the mercury recovery in the first four runs was poor. Runs $34 \mathrm{~b}$ and $34 \mathrm{c}$ were duplicates of the GF34 SRAT cycle to determine whether lowering the purge impacted process chemistry. In addition, runs GF40 and GF41 were SRAT and SME process simulations designed to determine whether the Glycolic-Nitric Acid flowsheet could successfully process the less washed simulants. Some data from the supernate runs is included in this section for completeness if they were not reported in Section 3.1.

\subsubsection{Off-gas}

Besides essentially eliminating hydrogen generation, the glycolic acid flowsheet also appears to stop or significantly slow down other off-gas generating reactions. Data is presented to summarize the results of these analyses. More detailed data is included in Appendix B.

\subsubsection{Hydrogen}

A main objective of this testing was to show that hydrogen generation could be mitigated or eliminated by the use of the glycolic/nitric flowsheet. Hydrogen was detected only in the GF40 and 41 SRAT cycles. These two runs had the "new lower purge" which led to higher measured hydrogen concentrations for a given generation rate. The GC hydrogen quantitation limit is 0.005 volume $\%$. The maximum hydrogen detected in these runs was 0.009 volume $\%$, which would have been below detection limits with the current DWPF scaled purge. Note that these runs were completed at approximately $130 \%$ stoichiometry and produced approximately $1 \%$ of the hydrogen compared to essentially identical runs with the Baseline flowsheet. Table 3-3 compares SRAT and SME cycle hydrogen on a DWPF scale. (Figure 3-5) summarizes the SRAT cycle hydrogen generation.

In the first four SME cycles (GF34, GF35, GF36, and GF37), formic acid was added with the frit in the SME cycle. In these runs, measurable hydrogen was generated, on the order of 0.05 volume percent. No formic acid was added in the GF40 and GF41 SME cycles. The GF41 hydrogen generation was just above quantitation limits in the GF40 SME cycle. In essentially identical runs with the Baseline flowsheet, the SME hydrogen limit was exceeded in runs at 125 and $130 \%$ acid stoichiometry. 
Table 3-3. Peak Hydrogen Generation

\begin{tabular}{|lccc|}
\hline Run & Sludge Composition & SRAT $\mathbf{H}_{\mathbf{2}}$, lb/hr & SME $\mathbf{H}_{\mathbf{2}}$, lb/hr \\
\hline DWPF & Current Limit & 0.65 & 0.223 \\
\hline GF34 & HiFeHiMn & $<0.0014$ & 0.00556 \\
\hline GF34b & HiFeHiMn & $<0.0014$ & No SME \\
\hline GF34c & HiFeHiMn & $<0.0014$ & No SME \\
\hline GF35 & SB7A & $<0.0014$ & 0.00398 \\
\hline GF36 & HiFeLoMn & $<0.0014$ & 0.0111 \\
\hline GF37b & HiFeLoMn & $<0.0014$ & No SME \\
\hline GF37c & HiFeLoMn & $<0.0014$ & No SME \\
\hline GF37 & LoFeLoMn & $<0.0014$ & 0.0157 \\
\hline GF37b & LoFeLoMn & $<0.0014$ & No SME \\
\hline GF38 & LoFeLoMn & $<0.0014$ & No SME \\
\hline GF39a, b, c, d, e & Supernate & $<0.0014$ & No SME \\
\hline GF40 & $1.6 \mathrm{M} \mathrm{Na}$ & 0.00287 & 0.00184 \\
\hline GF41 & $1.9 \mathrm{M} \mathrm{Na}$ & 0.00324 & $<0.0012$ \\
\hline
\end{tabular}

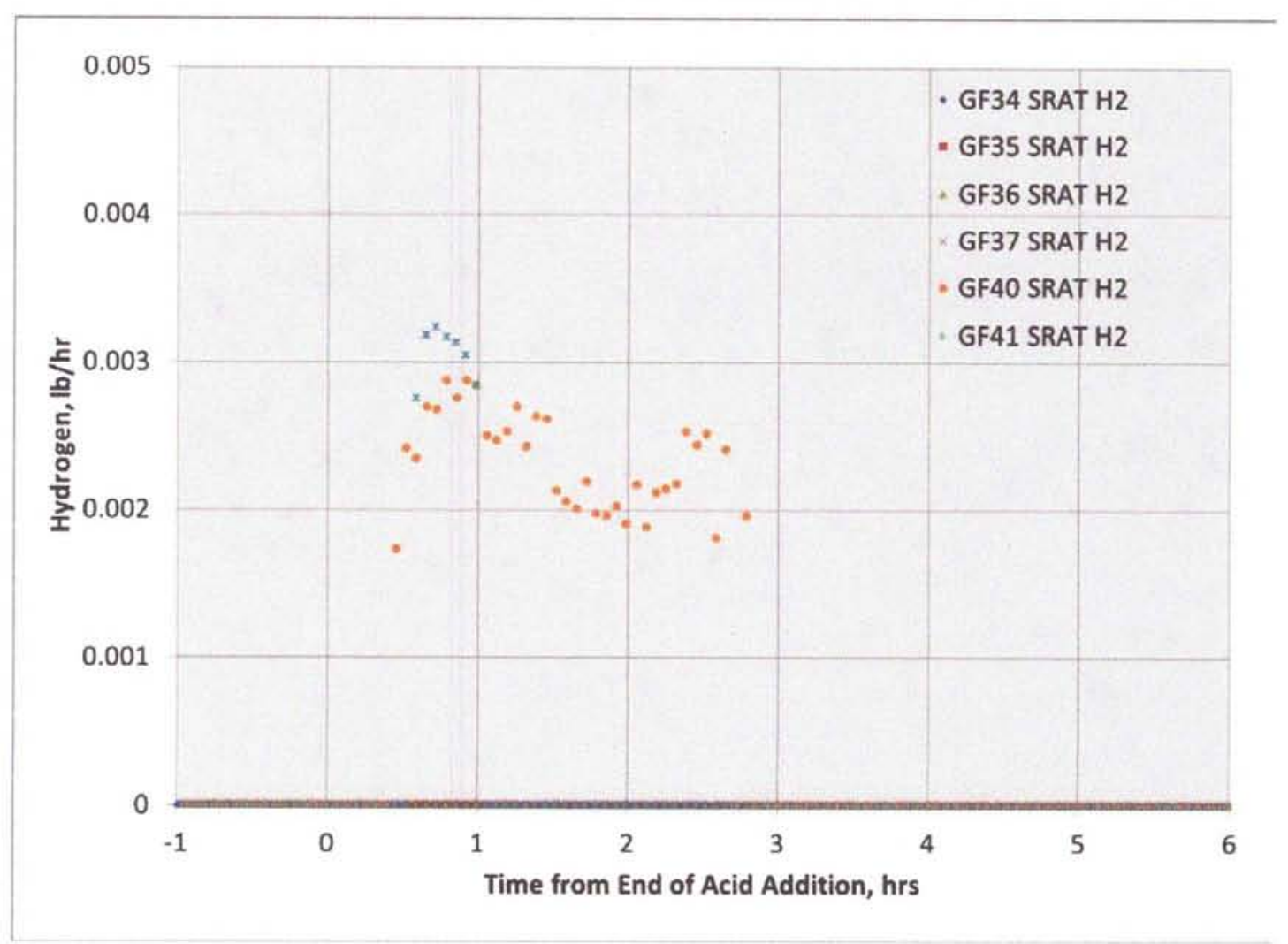

Figure 3-5. SRAT Cycle Hydrogen Generation 


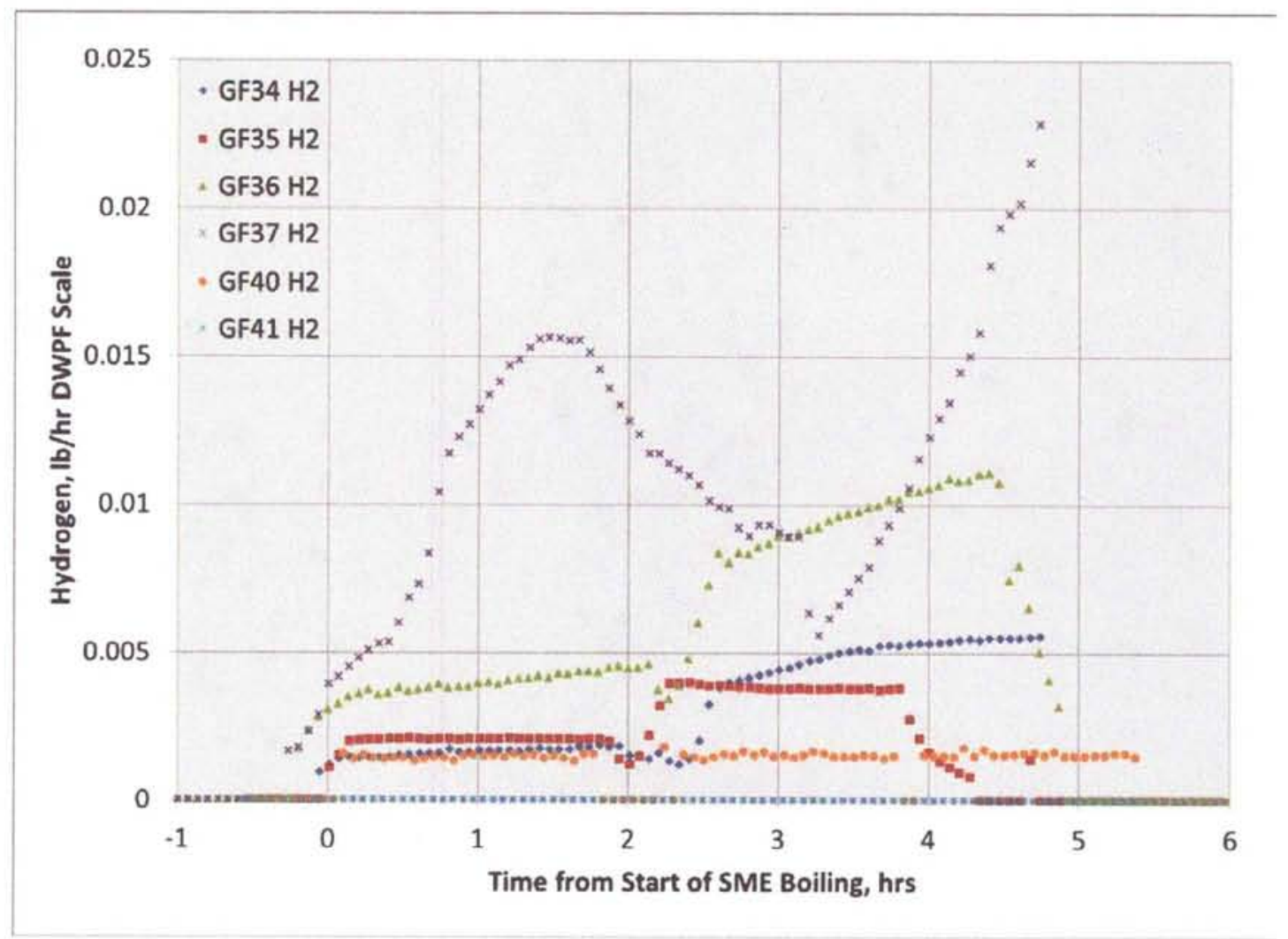

Figure 3-6. SME Cycle Hydrogen Generation

The MS was also used to measure hydrogen during Runs GF40 and GF41. The MS hydrogen peak was 0.025 volume \% in both the GF40 and GF41 SRAT cycles. This is almost three times the maximum detected by the GC. Although the potential detection limit is significantly lower for the MS (10 ppb) than the GC (10 ppm), quantification at these low concentrations is difficult due to variations in the background signal intensity. Therefore, the MS values can be considered qualitative at best. Both peaks occurred at boiling as is often the case in runs with low offgas generation $\left(\mathrm{H}_{2}\right.$ accumulated during frit slurry addition and was purged out as boiling was initiated). The comparison graph for Run GF40 is below (Figure 3-7). 
SRNL-STI-2012-00018

Revision 1

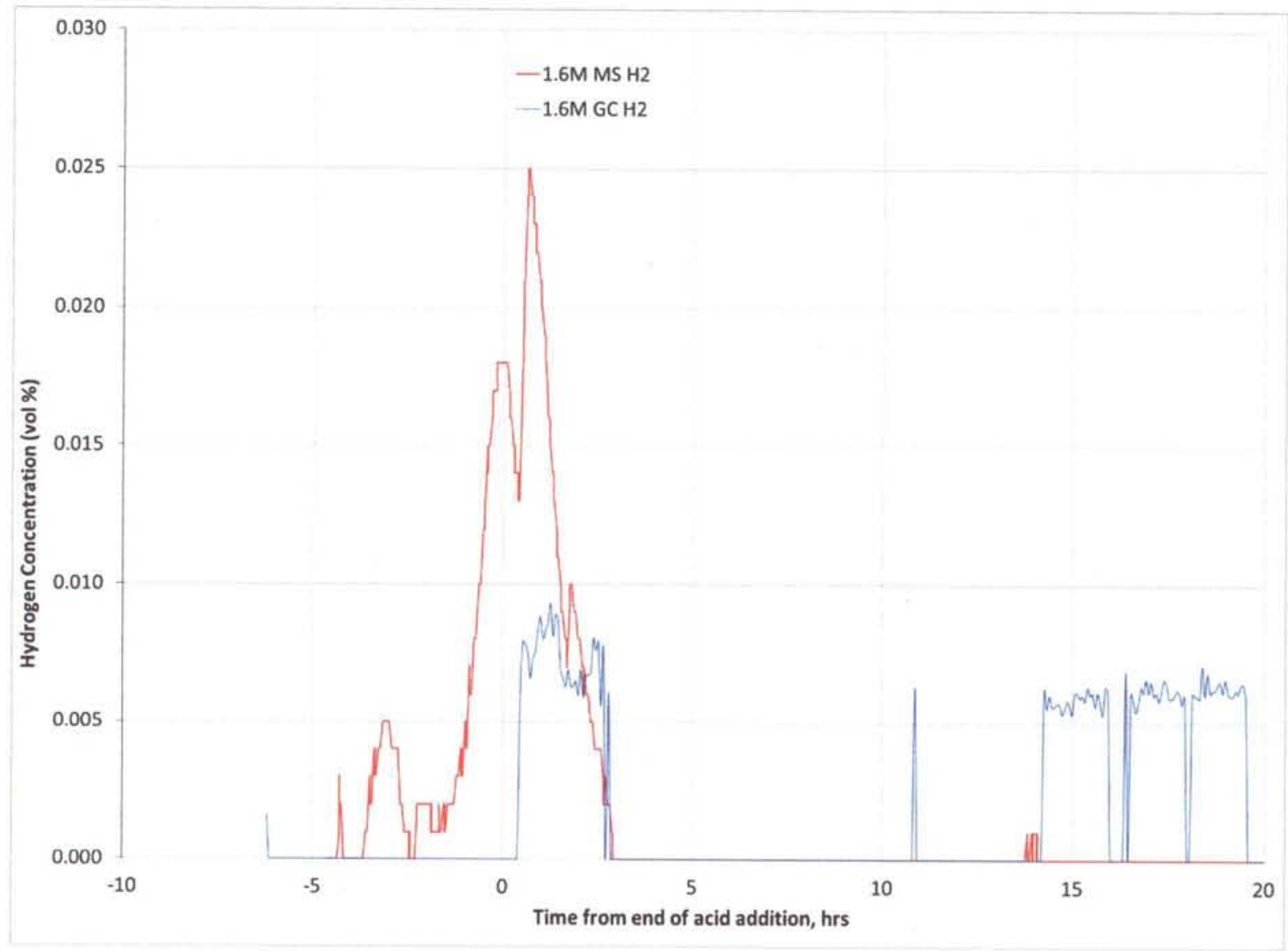

Figure 3-7. MS and GC Hydrogen Concentration

\subsubsection{Other Off-gas Components}

In addition to generation of hydrogen, other gases including carbon dioxide, carbon monoxide, and a number of oxides of nitrogen are produced. Only carbon dioxide and nitrous oxide $\left(\mathrm{N}_{2} \mathrm{O}\right)$ can be quantified using the gas chromatographs and calibration gas standards.

Carbon dioxide is the major off-gas generated, produced by the decomposition of carbonate species during acid addition. Table 3-4 and Figure 3-8 summarizes the carbon dioxide generation in the SRAT cycle. Table 3-5 and Figure 3-9 summarizes the carbon dioxide generation in the SME cycle. The $\mathrm{CO}_{2}$ generation post acid addition is mainly due to glycolate decomposition. The total $\mathrm{CO} 2$ produced with the glycolic-nitric flowsheet is approximately one-third compared to the baseline flowsheet. The small generation of $\mathrm{CO}_{2}$ in the SME cycle is triggered by decomposition of the formic acid that was added with the frit in the frit-slurry. This could be eliminated by not adding formic acid with frit in the SME cycle. 
Table 3-4. Comparison of SRAT Carbon Dioxide Generation Data

\begin{tabular}{|lcc|}
\hline Run & $\mathbf{C O}_{2}$ from Carbonate, $\mathbf{g}$ & $\mathbf{C O}_{2}$ in off-gas, $\mathbf{g}$ \\
\hline GF34 & 29.2 & 38.0 \\
\hline GF34b & 29.2 & 32.4 \\
\hline GF34c & 29.2 & 33.0 \\
\hline GF35 & 12.5 & 26.1 \\
\hline GF36 & 26.5 & 34.9 \\
\hline GF36b & 26.5 & 29.0 \\
\hline GF36c & 26.5 & 30.5 \\
\hline GF37 & 25.5 & 36.5 \\
\hline GF37b & 25.5 & 32.8 \\
\hline GF38 & 25.5 & 19.5 \\
\hline GF39a (Hg) & 12.9 & 17.2 \\
\hline GF39b (Hg + NM) & 12.9 & 22.0 \\
\hline GF39c (Hg+NM-Ru) & 12.9 & 18.6 \\
\hline GF39d (Hg + NM) & 12.9 & 16.2 \\
\hline GF40 & 20.5 & 45.8 \\
\hline GF41 & 19.3 & 50.8 \\
\hline
\end{tabular}


Revision 1

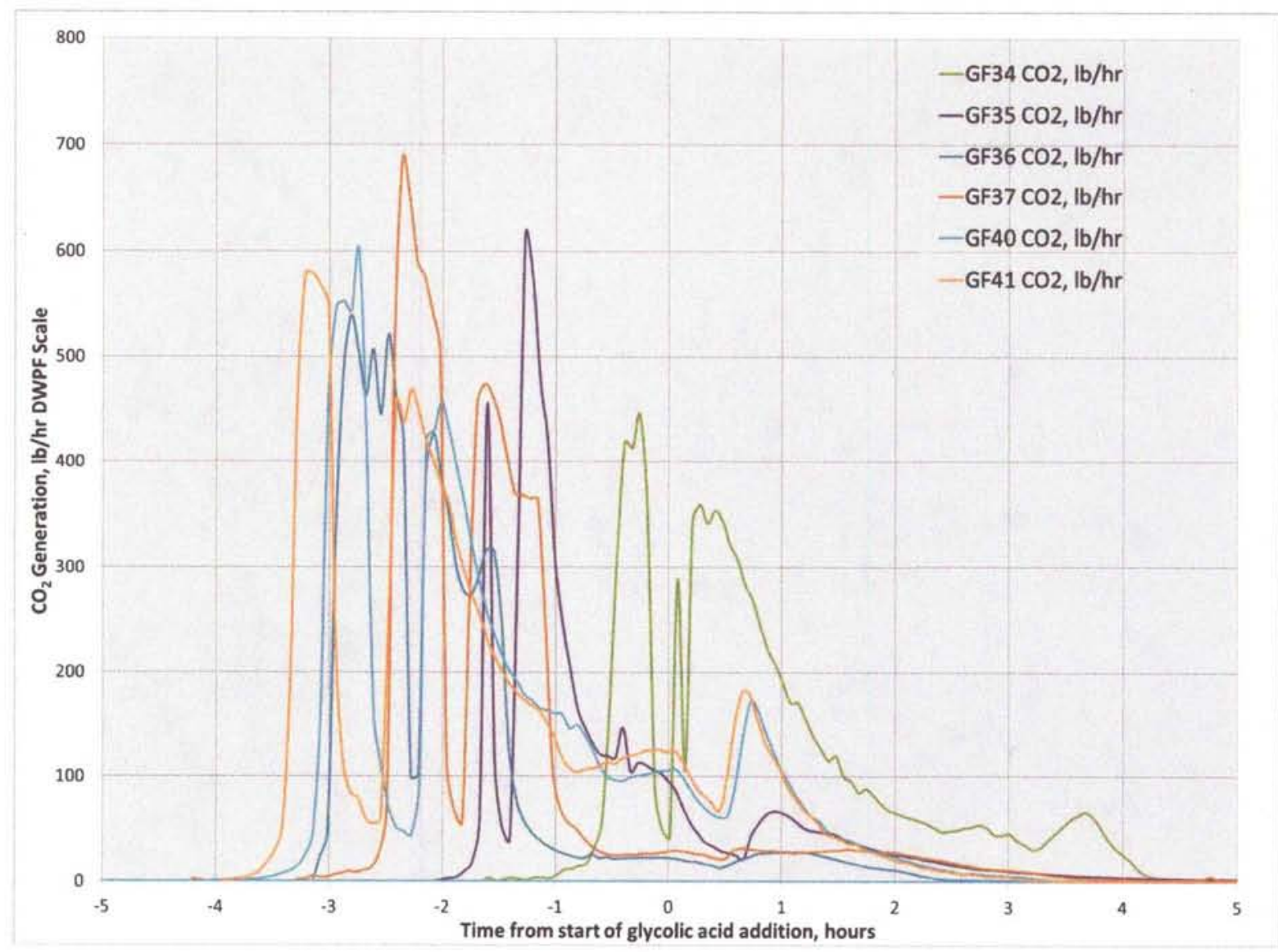

Figure 3-8. Carbon Dioxide Generation in SRAT cycles, lb/hr DWPF Scale

Table 3-5. Comparison of SME Carbon Dioxide Generation Data

\begin{tabular}{|lccc|}
\hline Run & $\begin{array}{c}\text { Potential } \mathrm{CO}_{2} \text { from } \\
\text { Added Formate, } \mathbf{g}\end{array}$ & $\begin{array}{c}\text { Measured } \mathbf{C O}_{2} \\
\text { in off-gas, }\end{array}$ & $\begin{array}{c}\text { Remaining Potential } \\
\mathbf{C O}_{2} \text { as formate, }\end{array}$ \\
\hline GF34 & 10.2 & 5.1 & 5.9 \\
\hline GF35 & 7.3 & 1.4 & 7.1 \\
\hline GF36 & 9.6 & 7.1 & 7.0 \\
\hline GF37 & 9.1 & 6.8 & 6.6 \\
\hline GF40 & 0 & 0.40 & $0^{\%}$ \\
\hline GF41 & 0 & 0.56 & 0 \\
\hline
\end{tabular}




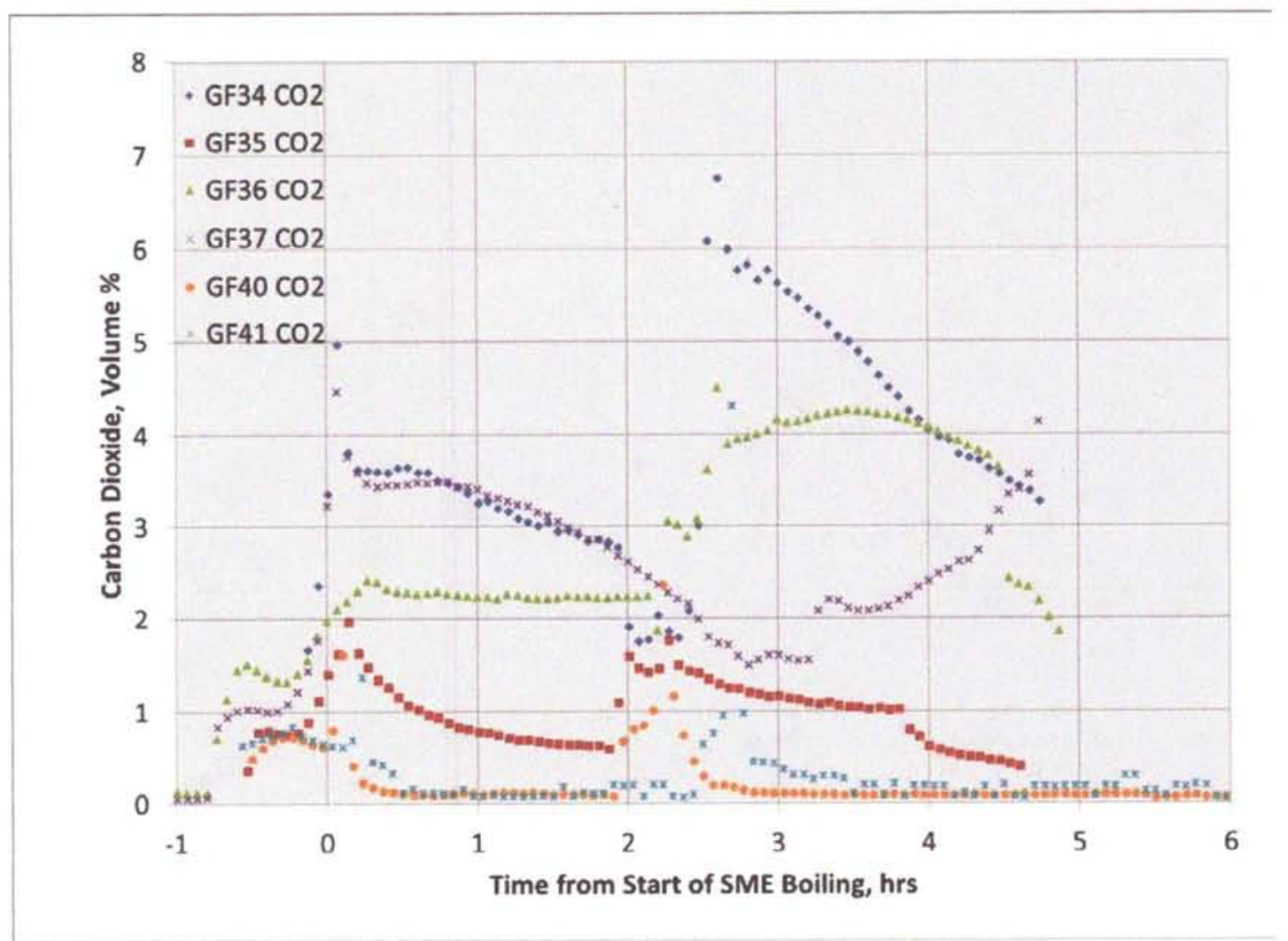

Figure 3-9. Carbon Dioxide Generation in SME cycles, lb/hr DWPF Scale

Most of the nitrite in the feed is converted to $\mathrm{NO}$ or $\mathrm{NO}_{2}$ during the SRAT cycle. However, these cannot be quantified with the gas chromatographs, although the yellow off-gas is indicative of significant $\mathrm{NO}_{2}$ in the off-gas. The production of $\mathrm{N}_{2} \mathrm{O}$ is minor; $1.6 \%-4.5 \%$ of the nitrite was converted to $\mathrm{N}_{2} \mathrm{O}$. Table 3-6 and Figure 3-10 summarizes the nitrous oxide generation in the SRAT cycle. In runs without added formic acid in the frit slurry, no $\mathrm{N}_{2} \mathrm{O}$ was detected in either the GF40 or GF41 SME cycle. 
Table 3-6. Comparison of SRAT Nitrous Oxide Generation Data

\begin{tabular}{|lccc|}
\hline Run & $\mathbf{N O}_{2}$ in feed, $\mathbf{g}$ & Potential $\mathbf{N}_{\mathbf{2}} \mathbf{O}$ from feed, $\mathbf{g}$ & Measured $\mathbf{~}_{\mathbf{2}} \mathbf{O}$ in off-gas, $\mathbf{g}$ \\
\hline GF34 & 51.9 & 24.8 & 0.69 \\
\hline GF34b & 51.9 & 24.8 & 0.33 \\
\hline GF34c & 51.9 & 24.8 & 0.31 \\
\hline GF35 & 27.9 & 13.3 & 0.59 \\
\hline GF36 & 51.6 & 24.7 & 0.38 \\
\hline GF36b & 51.6 & 24.7 & 0.35 \\
\hline GF36c & 51.6 & 24.7 & 0.34 \\
\hline GF37 & 52.5 & 25.1 & 0.67 \\
\hline GF37b & 52.5 & 25.1 & 0.45 \\
\hline GF38 & 52.5 & 25.1 & 0.21 \\
\hline GF40 & 40.9 & 19.5 & 0.55 \\
\hline GF41 & 47.9 & 22.9 & 0.77 \\
\hline
\end{tabular}

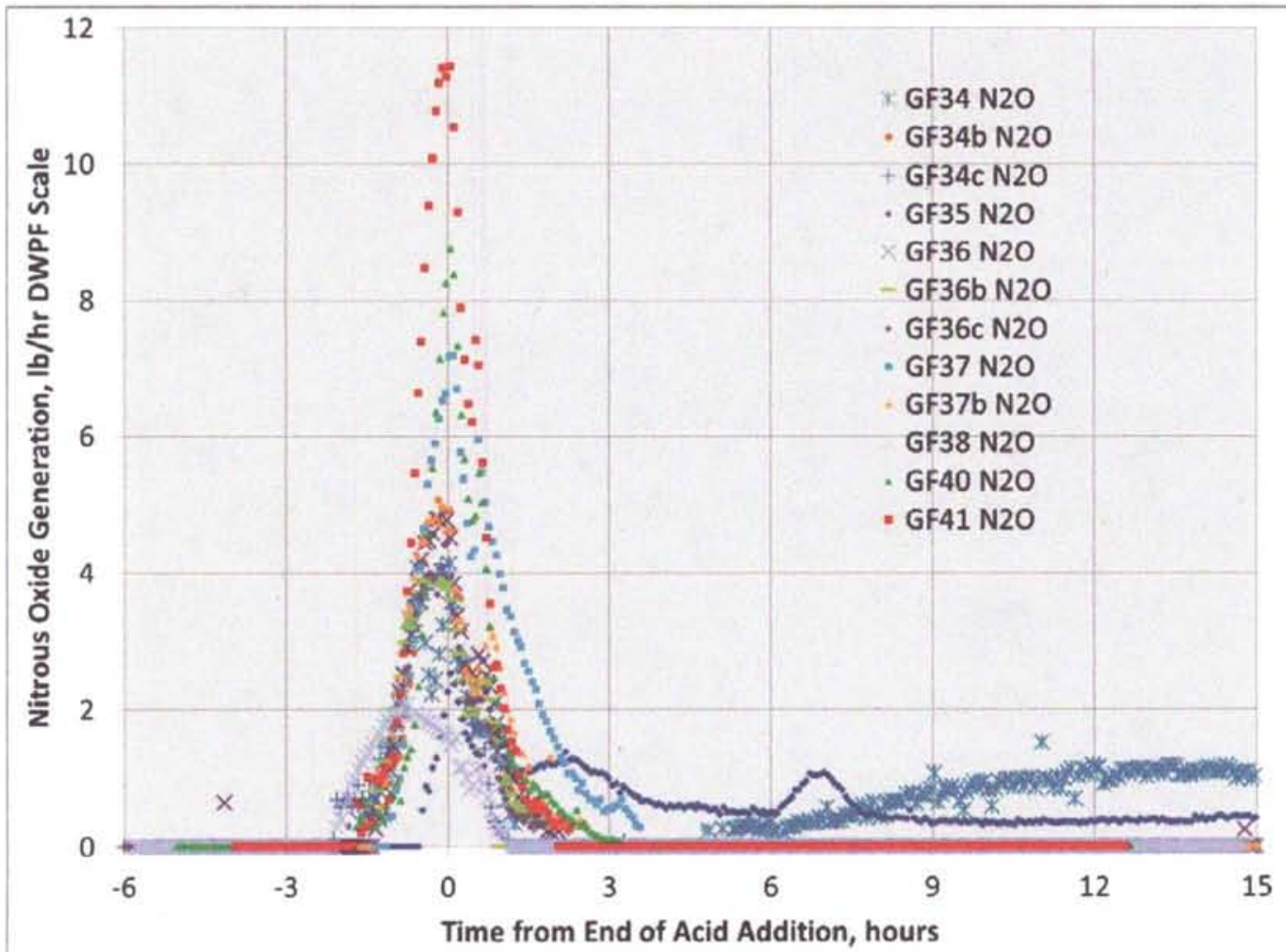

Figure 3-10. Nitrous Oxide Generation in SRAT cycles, lb/hr DWPF Scale

There was excellent agreement between the GC and MS for the major components in the offgas $\left(\mathrm{N}_{2}\right.$, $\mathrm{O}_{2}$, and $\mathrm{CO}_{2}$ ). In addition, the MS is able to measure $\mathrm{NO}_{\mathrm{x}}$ in the offgas. The data for GF40 is summarized in Figure 3-11. 


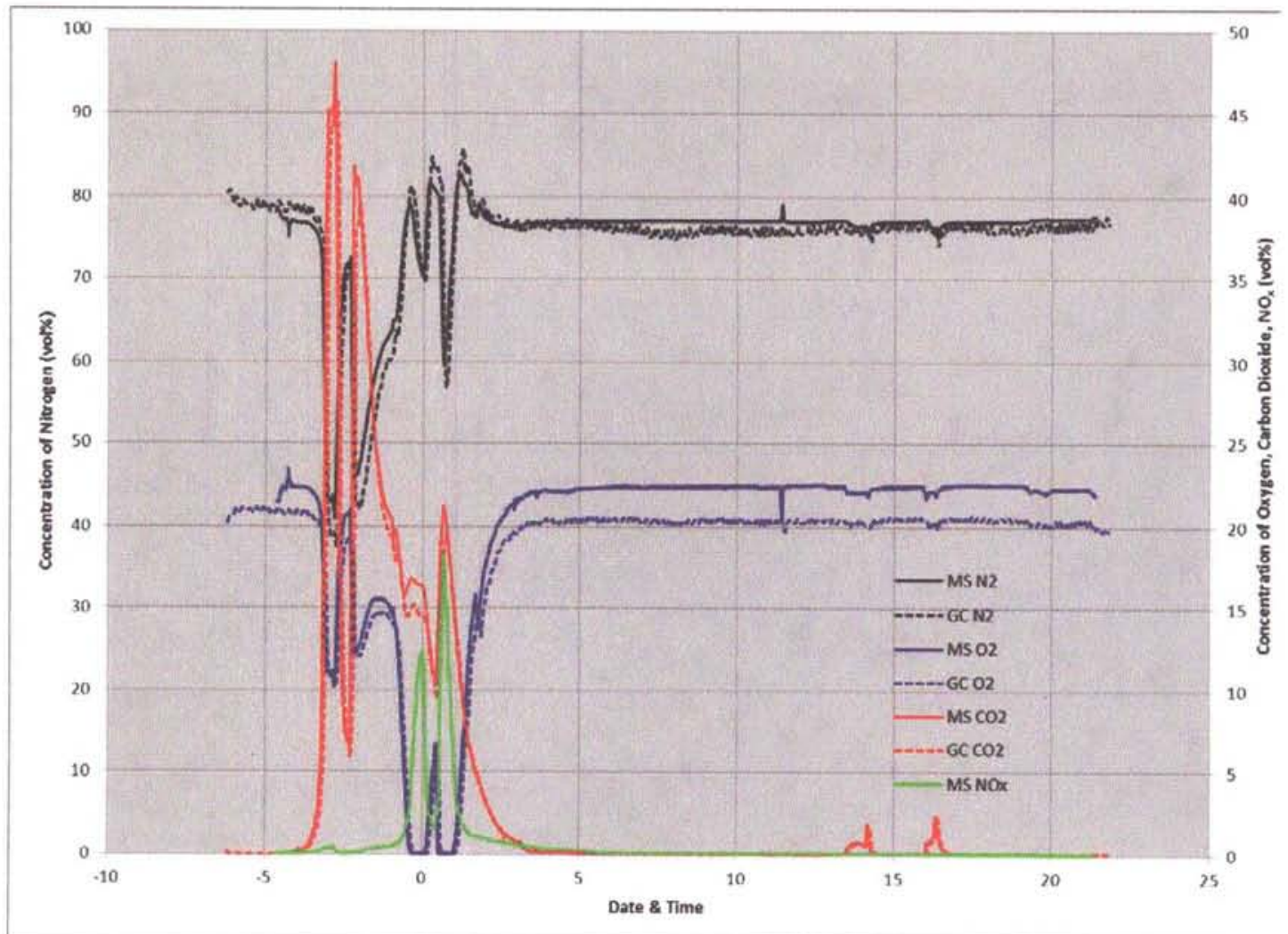

Figure 3-11. Nitrogen, Oxygen, Carbon Dioxide, $\mathrm{NO}_{\mathrm{x}}$ Generation in GF40 SRAT Cycle

The FTIR was able to measure $\mathrm{CO}_{2}, \mathrm{NO}, \mathrm{NO}_{2}, \mathrm{~N}_{2} \mathrm{O}$ and HMDSO. HMDSO is an expected degradation product of the current DWPF antifoam. The highest concentration detected for the HMDSO were at SRAT boiling and as boiling was initiated in the SME after each acid addition. The data are summarized in Figure 3-12.

A molar balance was used to compare the measured HMDSO to the potential HMDSO if all the antifoam decomposed to HMDSO. The HMDSO in the offgas was integrated to estimate the total HDMSO produced $(1.14 \mathrm{mmol})$. Based on the antifoam added throughout the run, $0.96 \mathrm{mmol}$ of HDMSO could be produced. Based on this calculation, $119 \%$ of the possible HMDSO was found in the offgas. This indicates that the the antifoam is completely hydrolyzing to HDMSO during SRAT and SME processing. The HDMSO is not being removed by the ammonia scrubber or the condensers. 
SRNL-STI-2012-00018

Revision 1

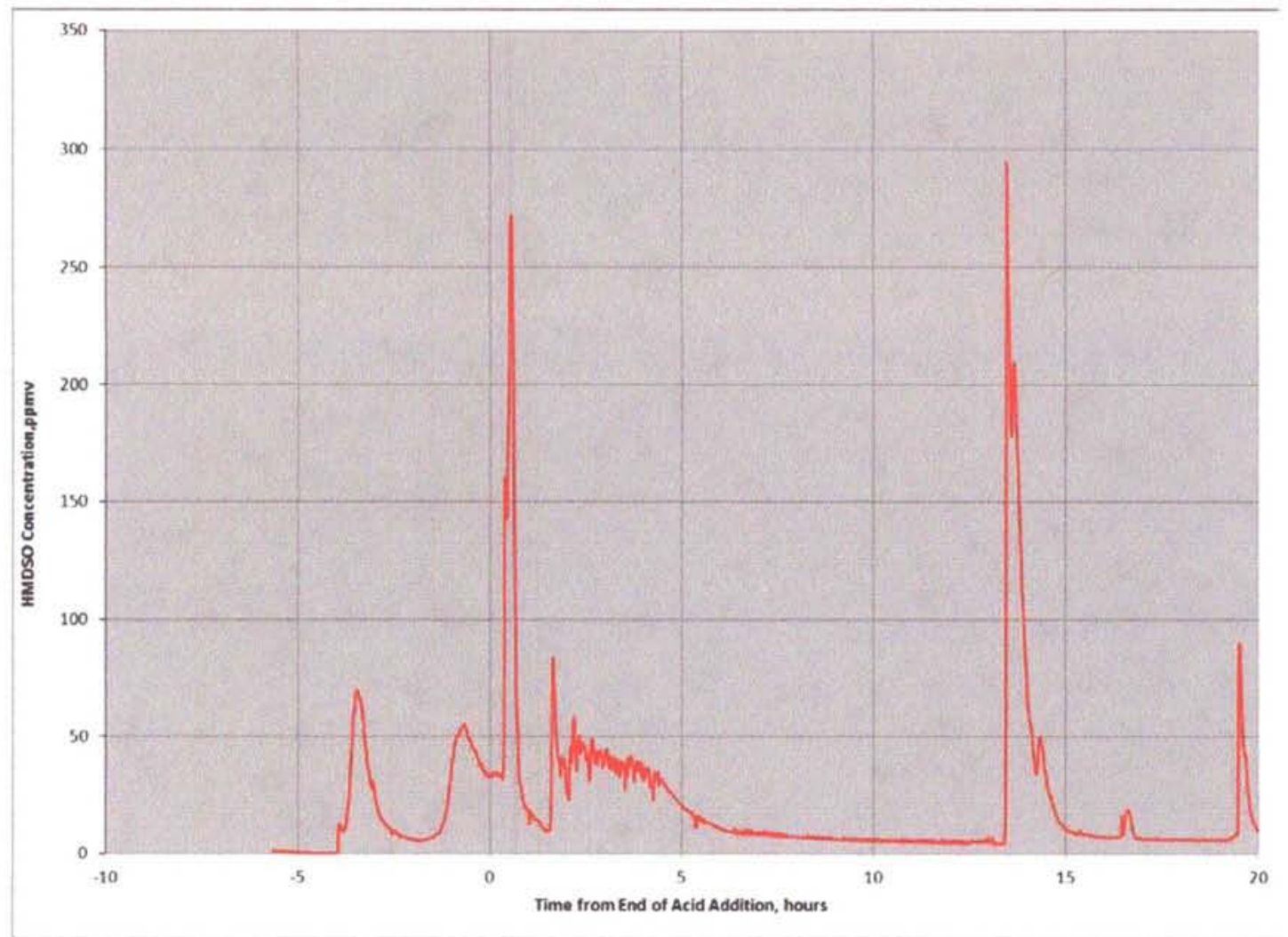

Figure 3-12. GF41 FTIR HMDSO Concentration, $\mathrm{ppm}_{\mathrm{v}}$

A comparison of data from the MS, GC and FTIR showed excellent agreement for $\mathrm{CO}_{2}$. The data is summarized in Figure 3-13. 




Figure 3-13. GF41 Carbon Dioxide Comparison between GF, MS and FTIR, volume \%

Nitrite generally decomposes to nitrate, $\mathrm{NO}_{2}, \mathrm{NO}$, and $\mathrm{N}_{2} \mathrm{O}$. The GC measured only the $\mathrm{N}_{2} \mathrm{O}$ concentration. With the addition of the MS and FTIR, all of these components can now be measured. It should be noted that the offgas samples are analyzed after the offgas has been through the SRAT condenser, MWWT, ammonia scrubber, and FAVC. The SRAT condenser and MWWT are both effective at scrubbing $\mathrm{NO}_{2}$ from the offgas so although $\mathrm{NO}_{2}$ is the major offgas species in the nitrite decomposition, little $\mathrm{NO}_{2}$ was measured by the FTIR and MS. In addition, the MS measured concentrations were about two times higher than the FTIR. The concentrations of $\mathrm{NO}_{2}$, $\mathrm{NO}$, and $\mathrm{N}_{2} \mathrm{O}$ are summarized in Figure 3-14. 


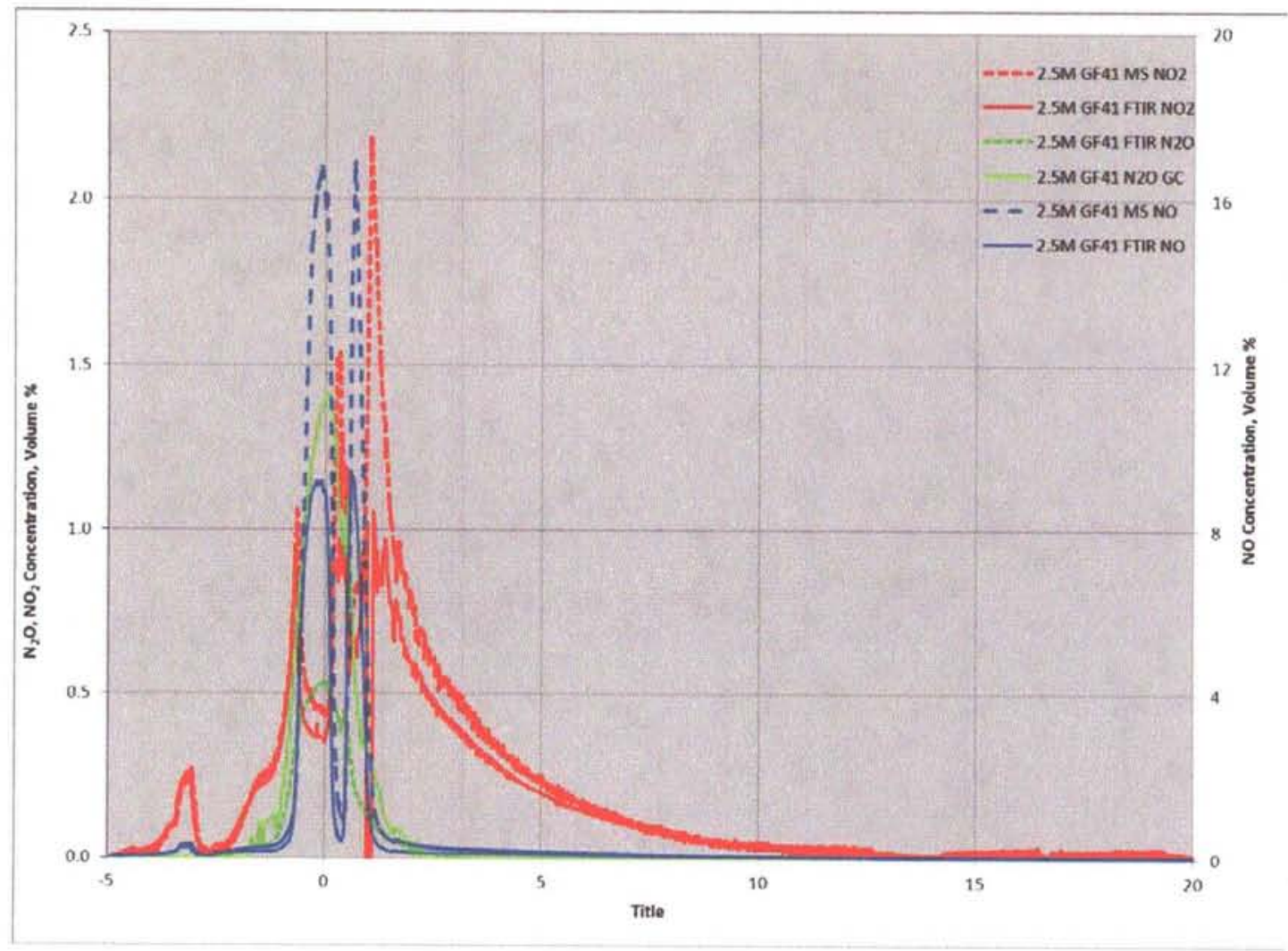

Figure 3-14. GF41 $\mathrm{NO}_{2}, \mathrm{NO}$, or $\mathrm{N}_{2} \mathrm{O}$ GC, MS and FTIR, volume $\%$

\subsubsection{SRAT Mercury Reduction and Stripping}

One of the most important questions to resolve concerning the glycolic-nitric acid flowsheet is whether mercury could be effectively reduced and steam stripped in the SRAT cycle without formic acid. In the Baseline flowsheet, mercury is reduced to elemental mercury during formic acid addition and then removed from the slurry by steam stripping during the concentration and reflux periods in SRAT processing.

The starting sludge was trimmed to $1.5 \mathrm{wt} \% \mathrm{Hg}$ in the total solids. This required a theoretical boiling time of 12 hours to remove mercury to less than $0.80 \mathrm{wt} \%$ in the SRAT product total solids using lab-scaled DWPF design basis boil-up rates and a stripping efficiency of $750 \mathrm{~g} \mathrm{steam} / \mathrm{g} \mathrm{Hg}$.

A mass balance was completed for each of the runs to attempt to determine where the mercury had accumulated. The mercury mass balance is summarized in Table 3-7. In three of the first four runs, GF34, 35, 36 and 37, the mercury recovery was poor in the MWWT. As a result, Runs 34, 36 and 37 were repeated (Runs GF34b, GF34c, GF36b, GF36c, GF37b and GF38). The mercury recovery in the second set of runs was typical for lab-scale SRAT cycles ${ }^{19}$. No cause for the differences in duplicate runs has been identified, but it is possible that there was technician error in collecting the mercury. Run GF35 (SB7A sludge) was not repeated, since the sludge was consumed in Run GF35. Run GF38 was performed at $125 \%$ acid stoichiometry to determine if acid stoichiometry impacted mercury recovery. Note that about $50 \%$ less mercury was recovered in the MWWT in run GF38 ( $125 \%$ acid stoichiometry) than was recovered in run GF37b (100\% acid stoichiometry). This phenomenon is also seen in Baseline flowsheet runs. 
Two SRAT and SME cycles (GF40 and GF41) were performed with two underwashed SB8 simulants to demonstrate that mercury can be reduced without formic acid in glycolic flowsheet runs with typical (not matrix) sludge simulant. These runs were completed in parallel with two Baseline flowsheet runs. The Glycolic-Nitric Flowsheet runs both had higher mercury recovery in the MWWT (same Koopman acid stoichiometry, same noble metals and mercury, essentially duplicate runs). In all Glycolic-Nitric acid flowsheet testing, the mercury stripping and recovery in the MWWT has either met or exceeded the recovery in the Baseline flowsheet runs.

Table 3-7. Mercury Balance in SRAT and SME Cycle, $g$

\begin{tabular}{|cccccccc|}
\hline Run & $\begin{array}{c}\text { \% Acid } \\
\text { Koopman }\end{array}$ & Added & MWWT & Slurry & $\begin{array}{c}\text { Conden } \\
\text { sate }\end{array}$ & Total & $\begin{array}{c}\text { \% } \\
\text { Recovery }\end{array}$ \\
\hline GF34 & 104.0 & 10.56 & 2.27 & 12.12 & 2.27 & 16.66 & $160 \%$ \\
\hline GF34b & 104.0 & 10.56 & 5.89 & 6.36 & NM & 12.3 & $116 \%$ \\
\hline GF34c & 104.0 & 10.56 & 1.94 & 7.10 & NM & 9.04 & $86 \%$ \\
\hline GF35 & 100.0 & 8.25 & 0.02 & 0.19 & 0.17 & 0.38 & $4.6 \%$ \\
\hline GF36 & 106.1 & 10.17 & 0.14 & 5.85 & 0.53 & 6.52 & $64 \%$ \\
\hline GF36b & 106.1 & 10.17 & 2.27 & 6.59 & NM & 8.85 & $87 \%$ \\
\hline GF36c & 106.1 & 10.17 & 2.35 & 7.17 & NM & 9.53 & $94 \%$ \\
\hline GF37 & 100.0 & 10.28 & 0.01 & 7.13 & 0.48 & 7.62 & $74 . \%$ \\
\hline GF37b & 100.0 & 10.28 & 4.10 & 4.75 & NM & 8.56 & $86 \%$ \\
\hline GF38 & 125 & 10.28 & 1.99 & 7.40 & NM & 9.15 & $91 \%$ \\
\hline GF40 & 130 & 11.15 & 3.79 & 5.21 & 0.44 & 9.44 & $85 \%$ \\
\hline GF41 & 130 & 11.15 & 3.24 & 5.34 & 0.46 & 9.03 & $81 \%$ \\
\hline
\end{tabular}

Samples were taken periodically throughout the runs for mercury analysis. The chart below (Figure 3-15) shows the concentration of mercury in the slurry as a function of time for the eight runs. It is expected that the mercury concentration will decrease linearly during SRAT steam stripping and collect in the MWWT. A linear decrease of $\mathrm{Hg}$ concentration in the slurry assumes a constant boil-up rate and a constant approach to thermodynamic vapor-liquid equilibrium between the slurry and off-gas phases. The general trend of the mercury profile curves is a linear decrease as expected. It was expected that the SRAT product would have a mercury concentration of $0.8 \mathrm{wt} \%$ or $2160 \mathrm{mg} / \mathrm{kg}$. The SRAT product $\mathrm{Hg}$ concentration ranged from $0.01-0.92 \mathrm{wt} \%$ total solids basis. Results are summarized Table 3-9. 


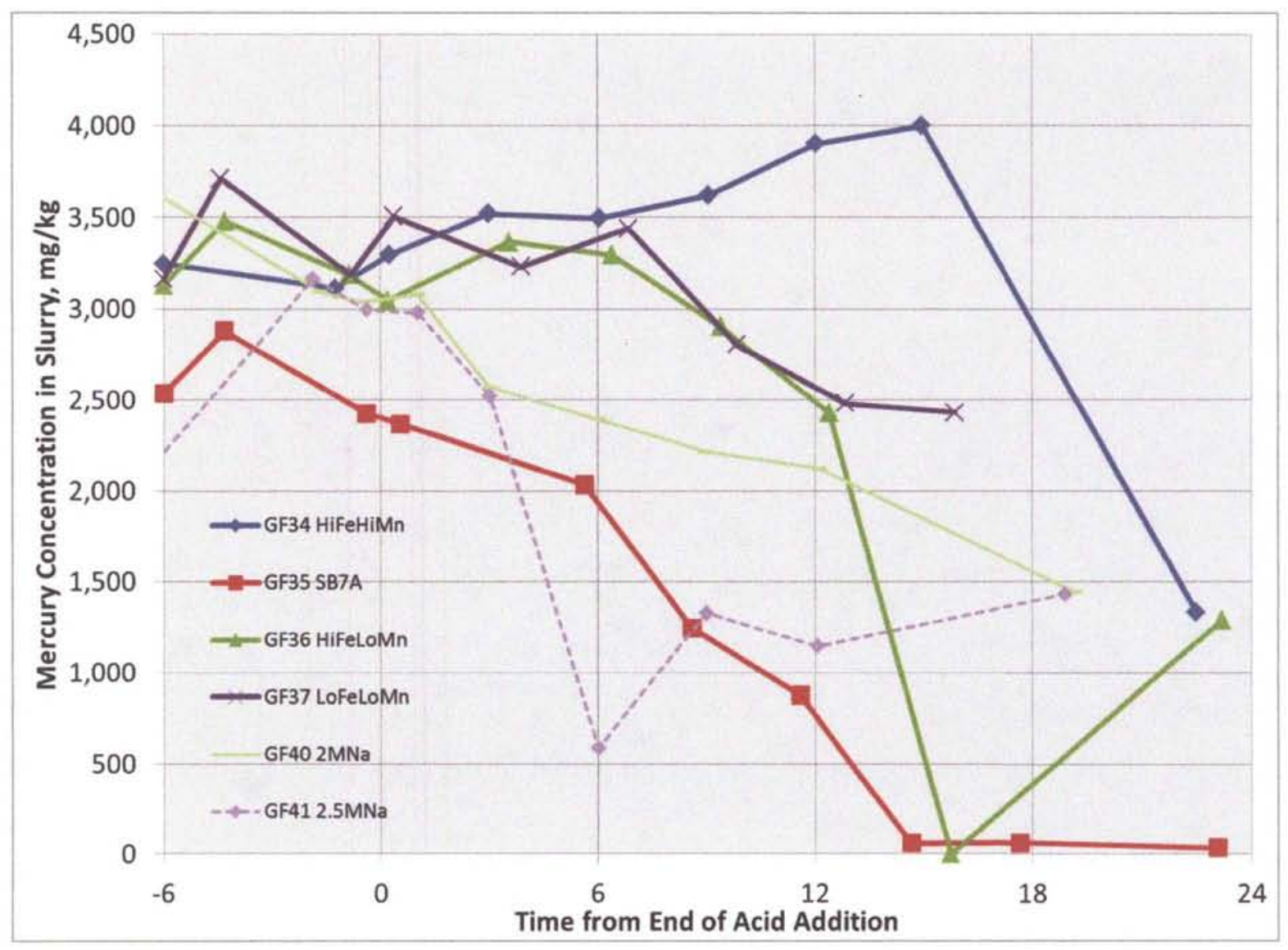

Figure 3-15. Mercury concentration versus time in Selected SRAT and SME cycles

Mercury is added to the sludge as $\mathrm{HgO}$. In these runs the $\mathrm{HgO}$ was slurried with water and homogenized using the vortex mixer to break up any clumps and allow an even dispersal of the mercury. During SRAT processing the mercury is first dissolved and may later be reduced to elemental mercury. Once it is reduced, it is insoluble and can be steam stripped. In Runs GF37b and GF38, extra samples were pulled during the acid addition and dewater phase to understand when these reactions occur. In both runs, approximately $90 \%$ of the mercury was dissolved prior to the completion of nitric addition and the $\mathrm{Hg}$ was completely dissolved by midway through the glycolic acid addition. The mercury then is reduced during the first two hours of dewatering (faster during GF 38 , the $125 \%$ acid stoichiometry run, than during GF37b, the $100 \%$ acid stoichiometry run). The dissolution and reduction of mercury was very similar to that seen for Pd. The concentration of $\mathrm{Hg}$ and Pd are summarized in Figure 3-16. 


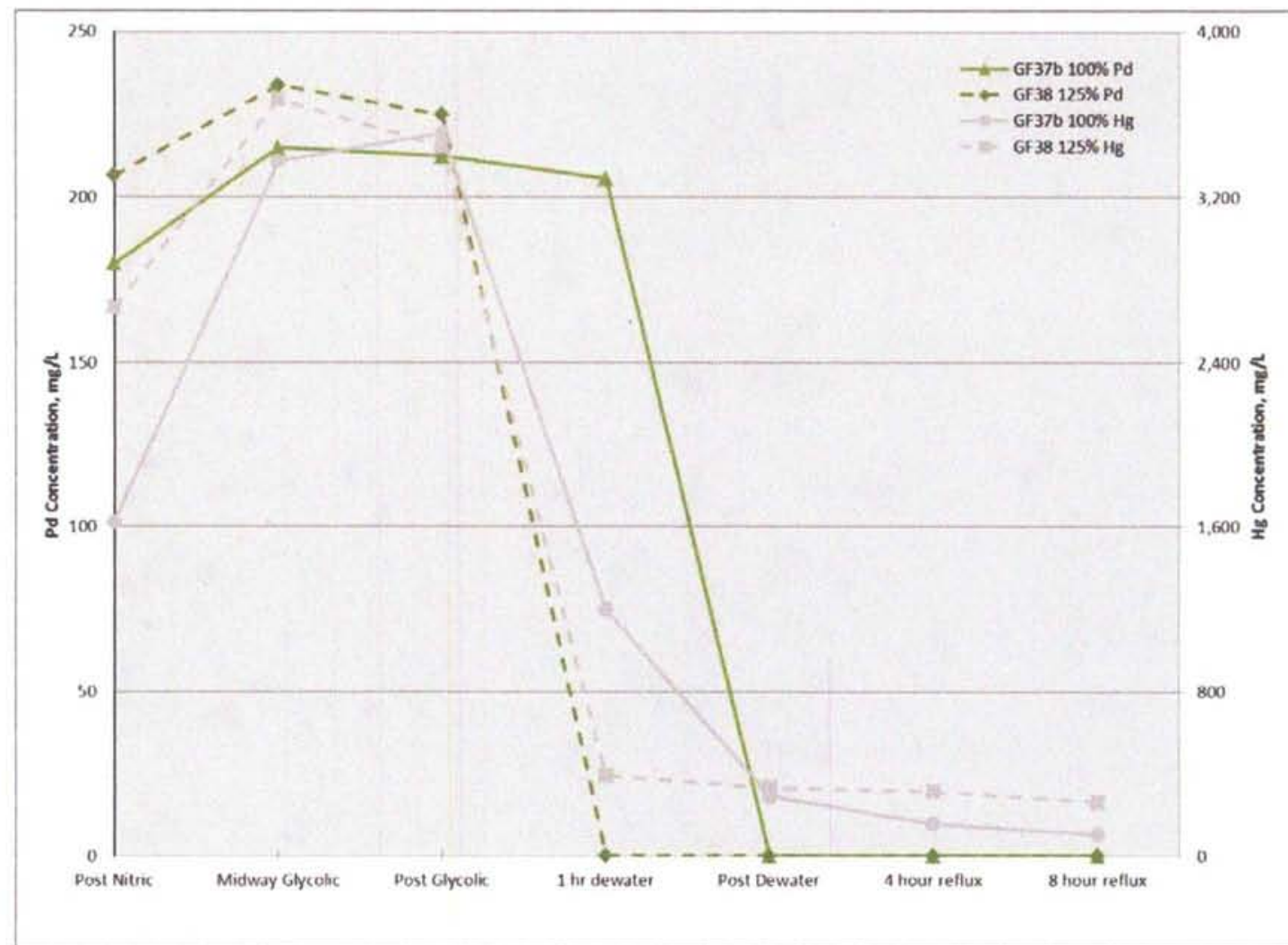

Figure 3-16. Mercury and Palladium Concentration for GF37b and GF38 SRAT Cycles

Mercury recovered in the MWWT was submitted to AD for crystal identification for the nonmetallic mercury recovered (the majority of the mercury is elemental mercury). The samples were analyzed by both X-ray Diffraction (XRD) and X-ray Fluorescence (XRF). Note that calomel formed in all four Glycolic Flowsheet runs and chloromagnesite formed in all runs with the underwashed sludges (the $\mathrm{Mg}$ concentration was nearly identical in all three sludges). Mosesite was only detected in the Baseline flowsheet runs. The main source of chloride in these runs is added chloride in $\mathrm{RuCl}_{3}$. The results are summarized in Table 3-8.

Table 3-8. XRD and XRF Identification of MWWT Crystals

\begin{tabular}{|cccc|}
\hline Run & Calomel $\left(\mathrm{Hg}_{2} \mathbf{C l}_{2}\right)$ & Mosesite $\left(\mathrm{Hg}_{2} \mathbf{N C l} \cdot \mathbf{H}_{2} \mathbf{O}\right)$ & Chloromagnesite $\left(\mathbf{M g C l}_{2}\right)$ \\
\hline GF34b & Yes & No & No \\
\hline GF34c & Yes & No & No \\
\hline Baseline 1.6 M Na & No & Yes & Yes \\
\hline Baseline 1.9 M Na & No & Yes & Yes \\
\hline GF40 (1.6 M Na) & Yes & No & Yes \\
\hline GF41 (1.9 M Na) & Yes & No & Yes \\
\hline
\end{tabular}

Mercury is being reduced by glycolic acid and approximately $30 \%$ of the mercury is removed from the SRAT by steam stripping and is collected in the MWWT. Approximately $40 \%$ of the mercury remains in the SME product. Another $4 \%$ was found in the condensate. There are two likely paths for condensate namely it can be removed by steam stripping (but not collect in the MWWT). This 
can happen in the SRAT cycle and SME cycle. In addition, the mercury can be dissolved by the strong acid in the condenser/MWWT condensate and overflow to the SMECT. In these tests little mercury was collected in the ammonia scrubber samples.

\subsubsection{SRAT Data}

SRAT cycle data is discussed in this section.

\subsubsection{SRAT Elemental Data}

General SRAT product slurry data for the twelve runs are tabulated below. Analyses were completed of both the slurry and supernate from all SRAT and SME products. The slurry results are summarized in Table 3-9. Conversion of the elemental data to the expected oxide form allows summing the oxides as a measure of both complete sample dissolution and accurate analysis of the major elements in the sludge product. The sum of oxides range from 98.2-100.5 over this data set (95-105 is considered acceptable). The slurry samples were filtered and the supernate results of these analyses are summarized in Table 3-10. The solubility of the cations is summarized in Table 3-11 
Table 3-9. SRAT Product Slurry PSAL Elemental Data, wt \% calcined solids basis

\begin{tabular}{|c|c|c|c|c|c|c|c|c|c|c|c|c|}
\hline Run & GF34 & GF34b & GF34c & GF35 & GF36 & GF36b & GF36c & GF37 & GF37b & GF38 & GF 40 & GF41 \\
\hline Al & 9.01 & 8.77 & 8.69 & 15.2 & 9.1 & 9.2 & 9.1 & 23.7 & 23.5 & 23.9 & 14.7 & 11.7 \\
\hline B & $<0.100$ & NM & NM & $<0.100$ & $<0.100$ & $<0.100$ & $<0.100$ & $<0.100$ & $<0.100$ & $<0.100$ & $<0.100$ & $<0.100$ \\
\hline $\mathrm{Ba}$ & 0.080 & 0.077 & 0.081 & 0.108 & 0.095 & 0.094 & 0.092 & 0.063 & 0.064 & 0.063 & 0.090 & 0.051 \\
\hline $\mathrm{Ca}$ & 3.58 & 3.74 & 3.77 & 0.80 & 2.12 & 1.95 & 1.94 & 1.68 & 1.66 & 1.69 & 0.601 & 0.431 \\
\hline $\mathrm{Cd}$ & $<0.010$ & NM & NM & $<0.010$ & $<0.010$ & $<0.010$ & $<0.010$ & $<0.010$ & $<0.010$ & $<0.010$ & NM & NM \\
\hline $\mathrm{Cr}$ & 0.017 & 0.016 & 0.016 & 0.067 & 0.273 & 0.269 & 0.269 & 0.223 & 0.224 & 0.220 & 0.025 & 0.023 \\
\hline $\mathrm{Cu}$ & 0.070 & 0.051 & 0.054 & 0.052 & 0.054 & 0.043 & 0.040 & 0.051 & 0.040 & 0.041 & 0.030 & 0.026 \\
\hline $\mathrm{Fe}$ & 32.3 & 31.1 & 31.3 & 20.5 & 32.0 & 32.9 & 32.9 & 12.6 & 12.3 & 12.3 & 14.2 & 12.7 \\
\hline Hg@ & 1.27 & 0.82 & 0.89 & 0.02 & 0.65 & 0.81 & 0.87 & 0.83 & 0.59 & 0.92 & 0.52 & 0.52 \\
\hline$K$ & 0.080 & 0.087 & 0.118 & 0.075 & 0.061 & 0.077 & 0.083 & 0.071 & 0.079 & 0.086 & 0.412 & 0.442 \\
\hline $\mathrm{Li}$ & $<0.100$ & NM & $\mathrm{NM}$ & $<0.100$ & $<0.100$ & NM & $\mathrm{NM}$ & $<0.100$ & $<0.100$ & $<0.100$ & $<0.100$ & $<0.100$ \\
\hline $\mathrm{Mg}$ & 0.410 & 0.389 & 0.401 & 0.382 & 2.57 & 2.77 & 2.76 & 2.36 & 2.40 & 2.43 & 0.398 & 0.258 \\
\hline Mn & 4.01 & 3.80 & 3.77 & 5.02 & 0.706 & 0.640 & 0.631 & 0.666 & 0.600 & 0.596 & 4.51 & 4.15 \\
\hline $\mathrm{Na}$ & 14.2 & 13.8 & 13.9 & 15.5 & 13.5 & 13.4 & 13.2 & 15.3 & 14.1 & 14.4 & 23.0 & 26.1 \\
\hline $\mathrm{Ni}$ & 0.212 & 0.182 & 0.189 & 3.42 & 2.69 & 2.73 & 2.73 & 2.37 & 2.35 & 2.37 & 1.95 & 1.55 \\
\hline $\mathbf{P}$ & $<0.100$ & $<0.100$ & $<0.100$ & $<0.100$ & $<0.100$ & $<0.100$ & $<0.100$ & $<0.100$ & $<0.100$ & $<0.100$ & $<0.100$ & $<0.100$ \\
\hline $\mathbf{P b}$ & 0.080 & 0.069 & 0.071 & 0.023 & 0.056 & 0.049 & 0.041 & 0.058 & 0.050 & 0.039 & $<0.010$ & $<0.010$ \\
\hline Pd & $<0.100$ & 0.03 & 0.03 & $<0.100$ & $<0.100$ & $<0.010$ & $<0.010$ & $<0.100$ & $<0.010$ & $<0.010$ & $<0.100$ & $<0.100$ \\
\hline $\mathbf{R h}$ & 0.031 & $<0.100$ & $<0.100$ & 0.032 & 0.033 & $<0.100$ & $<0.100$ & 0.047 & $<0.100$ & $<0.100$ & $<0.100$ & $<0.100$ \\
\hline $\mathbf{R u}$ & 0.032 & $<0.100$ & $<0.100$ & 0.031 & 0.032 & $<0.100$ & $<0.100$ & 0.030 & $<0.100$ & $<0.100$ & $<0.100$ & $<0.100$ \\
\hline $\mathrm{S}$ & 0.276 & 0.282 & 0.281 & 0.347 & 0.276 & 0.264 & 0.269 & 0.294 & 0.283 & 0.260 & 0.292 & 0.341 \\
\hline $\mathrm{Si}$ & 1.48 & 1.57 & 1.50 & 1.70 & 1.95 & 1.82 & 1.76 & 1.30 & 1.42 & 1.39 & 1.41 & 0.86 \\
\hline Sn & $<0.010$ & NM & NM & 0.029 & 0.107 & 0.102 & 0.102 & 0.089 & 0.094 & 0.093 & $\mathrm{NM}$ & NM \\
\hline Ti & 0.010 & $<0.010$ & $<0.010$ & 0.025 & 0.010 & $<0.010$ & $<0.010$ & 0.010 & $<0.010$ & $<0.010$ & 0.022 & 0.012 \\
\hline Zn & 0.062 & 0.063 & 0.065 & 0.064 & 0.072 & 0.071 & 0.070 & 0.061 & 0.062 & 0.062 & 0.046 & 0.039 \\
\hline $\mathbf{Z r}$ & 0.055 & 0.051 & 0.054 & 0.236 & 0.117 & 0.110 & 0.110 & 0.045 & 0.040 & 0.044 & 0.201 & 0.178 \\
\hline
\end{tabular}

(a) Hg reported on a total solids basis 
Table 3-10. SRAT Product Supernate PSAL Elemental Data, mg/L supernate basis

\begin{tabular}{|c|c|c|c|c|c|c|c|c|c|c|c|c|}
\hline Run & GF34 & GF34b & GF34c & GF35 & GF36 & GF36b & GF36c & GF37 & GF37b & GF38 & GF40 & GF41 \\
\hline Al & 292 & 1,060 & 1,230 & 217 & 411 & 2,280 & 2,250 & 554 & 2,210 & 4,040 & 1,720 & 1,970 \\
\hline B & 1.22 & NM & $\mathrm{NM}$ & 1.28 & 1.23 & $<10.0$ & $<10.0$ & 1.49 & $<10.0$ & $<10.0$ & $<10.0$ & $<10.0$ \\
\hline $\mathrm{Ba}$ & 2.18 & 4.33 & 4.44 & 0.99 & 1.65 & 3.28 & 3.32 & 1.26 & 2.69 & 3.37 & 9.37 & 11.0 \\
\hline $\mathrm{Ca}$ & 2,390 & 4,150 & 4,200 & 109 & 2,390 & 3,350 & 3,490 & 2,150 & 3,040 & 2,870 & 368 & 403 \\
\hline Cd & $<0.010$ & NM & $\overline{N M}$ & $<0.010$ & $<0.010$ & $<0.100$ & $<0.100$ & $<0.010$ & $<0.100$ & $<0.100$ & NM & NM \\
\hline $\mathrm{Cr}$ & 2.58 & 4.34 & 4.85 & 3.52 & 32.0 & 54.8 & 53.7 & 86.0 & 103 & 198 & 27.4 & 29.8 \\
\hline $\mathrm{Cu}$ & 11.6 & 20.8 & 23.0 & 1.33 & 11.9 & 25.9 & 24.6 & 15.1 & 24.7 & 38.5 & 19.4 & 21.9 \\
\hline $\mathrm{Fe}$ & 1,670 & 4,470 & 5,220 & 141 & 1,040 & 2,810 & 3,290 & 328 & 1,490 & 3,560 & 5,510 & 4,950 \\
\hline $\mathbf{K}$ & 392 & 303 & 422 & 321 & 272 & 16.4 & 5.23 & 290 & 265 & 247 & 918 & 985 \\
\hline La & 27.8 & NM & $\mathrm{NM}$ & 2.84 & 18.6 & 239 & 269 & 39.2 & NM & NM & $<10.0$ & $<10.0$ \\
\hline $\mathbf{L i}$ & $<10.0$ & NM & NM & $<10.0$ & $<10.0$ & $<1.00$ & $<1.00$ & $<10.0$ & $<1.00$ & $<1.00$ & $<10.0$ & $<10.0$ \\
\hline $\mathrm{Mg}$ & 309 & 256 & 268 & 203 & 4,830 & 4,460 & 4,040 & 4,410 & 4,090 & 4,180 & 280 & 316 \\
\hline Mn & 8,850 & 7,060 & 7,370 & 2,670 & 1,330 & 1,280 & 1,150 & 1,300 & 1,280 & 922 & 5,130 & 4,190 \\
\hline $\mathrm{Na}$ & 30,100 & 24,900 & 15,400 & 33,700 & 26,500 & 28,200 & 25,900 & 30,400 & 29,800 & 28,500 & 44,300 & 47,800 \\
\hline Nd & 7.13 & NM & NM & 0.61 & 4.58 & 10.77 & 9.84 & 10.71 & NM & NM & NM & NM \\
\hline $\mathbf{N i}$ & 121 & 117 & 123 & 100 & 2,940 & 3,160 & 2,850 & 3,160 & 3,180 & 3,960 & 732 & 659 \\
\hline $\mathbf{P}$ & 0.86 & $<1.00$ & $<1.00$ & 1.04 & 1.13 & 1.54 & 1.86 & 1.56 & $<10.0$ & $<10.0$ & 14 & 20.6 \\
\hline $\mathbf{P b}$ & 4.10 & 4.73 & 5.14 & 0.17 & 0.61 & 2.29 & 2.01 & 2.31 & 4.15 & 18.9 & 6.73 & 9.91 \\
\hline Pd & 0.16 & 0.123 & 0.122 & 0.21 & 0.16 & 0.18 & 0.13 & 0.18 & $<0.100$ & $<.100$ & $<1.00$ & $<1.00$ \\
\hline $\mathbf{R h}$ & 2.97 & 15.9 & 10.4 & 9.21 & 10.7 & 18.4 & 15.0 & 12.0 & 36.0 & 78.3 & 30.5 & 31.4 \\
\hline Ru & 106 & 174 & 125 & 25.6 & 181 & 229 & 206 & 289 & 330 & 453 & 54.1 & 65.9 \\
\hline $\mathrm{S}$ & 645 & 439 & 446 & 880 & 572 & 453 & 482 & 672 & 599 & 513 & 583 & 622.7 \\
\hline $\mathrm{Si}$ & 23.5 & 52.3 & 55.8 & 38.3 & 17.4 & 132 & 68.8 & 67.4 & 121 & 103 & 44.4 & 77.8 \\
\hline $\mathrm{Sr}$ & 4.17 & NM & NM & 2.32 & 3.06 & NM & $\mathrm{NM}$ & 2.99 & 41.6 & 77.3 & $\mathrm{NM}$ & NM \\
\hline $\mathrm{Ti}$ & $<0.010$ & $<0.100$ & $<0.100$ & $<0.010$ & $<0.010$ & $<0.100$ & $<0.100$ & $<0.010$ & $<0.100$ & $<0.100$ & 0.700 & 0.867 \\
\hline $\mathbf{Z n}$ & 25.7 & 30.3 & 33.7 & 0.400 & 28.6 & 34.1 & 34.0 & 39.6 & 42.8 & 64.6 & 22.0 & 27.1 \\
\hline $\mathbf{Z r}$ & 6.29 & 20.9 & 23.8 & 22.6 & 14.5 & 60.9 & 62.0 & 17.7 & 38.3 & 50.7 & 195 & 208 \\
\hline
\end{tabular}


Table 3-11. Major Components: SRAT Product \% of Element Dissolved

\begin{tabular}{|lccccc|}
\hline Run & Al & Fe & Na & Mg & Mn \\
\hline GF34 HiFeHiMn & 1.3 & 2.1 & 87.5 & 31.0 & 90.8 \\
\hline GF34b HiFeHiMn & 0.0011 & 7.3 & 90.8 & 33.3 & 93.8 \\
\hline GF34c HiFeHiMn & 0.0010 & 8.5 & 92.7 & 34.1 & 99.9 \\
\hline GF35SB7A & 0.6 & 0.3 & 92.9 & 22.7 & 22.7 \\
\hline GF36 HiFeLoMn & 2.0 & 1.5 & 88.2 & 84.0 & 84.6 \\
\hline GF36b HiFeLoMn & 12.9 & 4.4 & 88.2 & 84.0 & 84.6 \\
\hline GF36c HiFeLoMn & 12.7 & 5.1 & 108.6 & 83.2 & 103.4 \\
\hline GF37 LoFeLoMn & 1.1 & 1.2 & 94.9 & 89.0 & 93.1 \\
\hline GF37b LoFeLoMn & 4.8 & 6.3 & 108.8 & 88.1 & 110.2 \\
\hline GF38 LoFeLoMn & 9.4 & 16.2 & 109.6 & 95.8 & 86.0 \\
\hline GF40 & 6.0 & 20.1 & 99.7 & 48.7 & 58.8 \\
\hline GF41 & 9.3 & 21.7 & 102 & 68.2 & 56.1 \\
\hline
\end{tabular}

\subsubsection{SRAT Anion Data}

Ion Chromatography using weighted dilutions of samples (not the AD acid strike oxalate method) was performed on both the slurry and supernate from all SRAT and SME products. The slurry results are summarized in Table 3-12. The slurry samples were filtered and the supernate results of these analyses are summarized in Table 3-13. SRAT Product Filtrate PSAL Anion Data, mg/L Supernate Basis

Anion balance data for nitrite, nitrate, formate and glycolate are presented in the table below for all runs (Table 3-14).

The SRAT and SME product oxalate results are of particular interest. The starting sludge contained about $800 \mathrm{mg} / \mathrm{kg}$ oxalate, which could be partially destroyed catalytically during the SRAT cycle. In the glycolic/formic flowsheet runs, however, oxalate was being created. The glycolic acid is likely oxidized to glyoxylic acid $\left(\mathrm{HCOCO}_{2} \mathrm{H}\right)$ by nitrite, which is further oxidized to oxalic acid by the reduction of mercury. However, more experiments are needed to pinpoint the reaction pathways. 
Table 3-12. SRAT Product Slurry PSAL Anion Data, mg/kg Slurry Basis

\begin{tabular}{|llllllll|}
\hline Run & Formate & Chloride & Nitrite & Nitrate & Sulfate & Oxalate & Glycolate \\
\hline GF34 & $<100$ & 650 & $<100$ & 57,150 & 1,250 & 1,990 & 44,850 \\
\hline GF34b & $<100$ & 649 & $<100$ & 54,450 & 1,910 & 4,970 & 46,450 \\
\hline GF34c & $<100$ & 717 & $<100$ & 53,900 & 2,720 & 5,860 & 50,000 \\
\hline GF35 & $<100$ & 572 & $<100$ & 43,450 & 1,910 & 4,370 & 39,850 \\
\hline GF36 & $<100$ & 622 & $<100$ & 57,500 & 1,210 & 3,955 & 37,250 \\
\hline GF36b & $<100$ & 591 & $<100$ & 56,650 & 1,280 & 3,190 & 51,250 \\
\hline GF36c & $<100$ & 602 & $<100$ & 56,350 & 1,240 & 3,210 & 53,100 \\
\hline GF37 & $<100$ & 821 & $<100$ & 56,550 & 1,500 & 2,755 & 42,200 \\
\hline GF37b & $<100$ & 590 & $<100$ & 52,500 & 1,445 & 2,420 & 55,450 \\
\hline GF38 & $<100$ & 583 & $<100$ & 56,900 & 1,420 & 2,655 & 77,850 \\
\hline GF40 & $<100$ & $<500$ & $<100$ & 48,200 & 1,780 & 17,000 & 49,200 \\
\hline GF41 & $<100$ & $<500$ & $<100$ & 41,700 & 1,220 & 13,300 & 48,600 \\
\hline
\end{tabular}

Table 3-13. SRAT Product Filtrate PSAL Anion Data, mg/L Supernate Basis

\begin{tabular}{|lrrrrrrr|}
\hline Run & Formate & Chloride & Nitrite & Nitrate & Sulfate & Oxalate & Glycolate \\
\hline GF34 & $<100$ & 894 & $<100$ & 80,500 & 2,250 & 1,570 & 56,300 \\
\hline GF34b & $<100$ & 806 & $<100$ & 71,000 & 2,280 & 6,310 & 58,400 \\
\hline GF34c & $<100$ & 931 & $<100$ & 70,900 & 3,520 & 7,730 & 66,500 \\
\hline GF35 & $<100$ & 823 & $<100$ & 63,700 & 2,790 & 3,800 & 48,600 \\
\hline GF36 & $<100$ & 858 & $<100$ & 86,300 & 2,170 & 3,250 & 46,700 \\
\hline GF36b & $<100$ & 736 & $<100$ & 74,000 & 1,530 & 4,060 & 64,500 \\
\hline GF36c & $<100$ & 783 & $<100$ & 74,300 & 1,610 & 4,240 & 70,700 \\
\hline GF37 & $<100$ & 913 & $<100$ & 82,100 & 2,740 & 3,860 & 61,300 \\
\hline GF37b & $<100$ & 772 & $<100$ & 70,900 & 1,850 & 3,030 & 72,500 \\
\hline GF38 & $<100$ & 746 & $<100$ & 77,300 & 1,790 & 3,605 & 98,100 \\
\hline GF40 & $<500$ & $<500$ & $<500$ & 60,400 & 1,910 & 11,100 & 50,300 \\
\hline GF41 & $<500$ & $<500$ & $<500$ & 76,100 & 2,340 & 14,700 & 57,500 \\
\hline
\end{tabular}

Table 3-14. SRAT Cycle Anion Balance Data, \%

\begin{tabular}{|ccccc|}
\hline Run & $\begin{array}{c}\text { Nitrite } \\
\text { Destruction }\end{array}$ & Glycolate Destruction & $\begin{array}{c}\text { Nitrite to Nitrate } \\
\text { Conversion }\end{array}$ & $\begin{array}{c}\text { SRAT Oxalate } \\
\text { Generation }\end{array}$ \\
\hline GF34 & 100 & 32.8 & 54.7 & 623 \\
\hline GF34b & 100 & 29 & 40 & 1700 \\
\hline GF34c & 100 & 25.9 & 37.2 & 2010 \\
\hline GF35 & 100 & 26 & 14.7 & -49.4 \\
\hline GF36 & 100 & 42.6 & 27.1 & 1,420 \\
\hline GF36b & 100 & 20.1 & 32.9 & 1,140 \\
\hline GF36c & 100 & 16.7 & 31.9 & 1,150 \\
\hline GF37 & 100 & 27.4 & 49.5 & 867 \\
\hline GF37b & 100 & 9.8 & 19.9 & -18 \\
\hline GF38 & 100 & -12.4 & 18.3 & -11.1 \\
\hline GF40 & 100 & -5.7 & 65.9 & 22.5 \\
\hline GF41 & 100 & 0.81 & 41.5 & 17.1 \\
\hline
\end{tabular}


As a result of uncertainty of the anion analyses, four samples were submitted to AD for both TOC and anion analysis. The data below (Table 3-16) shows the results from both PSAL and AD for comparison. The agreement is fairly good, with the exception of the glycolate and oxalate. In addition, the carbon species (formate, oxalate, glycolate) were converted to carbon concentrations and summed to estimate the Total Organic Carbon (TOC) result for each sample. These results were compared to the $\mathrm{AD}$ measured TOC result. It is obvious that the TOC predicted from the PSAL results agreed well with the TOC measurement.

Table 3-15. \% Anion Dissolved in SRAT Products

\begin{tabular}{|lcccccc|}
\hline Run & Chloride & Glycolate & Nitrate & Oxalate & Sulfate & Sulfate (S)* \\
\hline GF34 & 101.7 & 92.9 & 104.1 & 58.2 & 133.1 & 96.1 \\
\hline GF34b & 99.6 & 59.3 & 98.7 & 41.6 & 114.8 & 78.5 \\
\hline GF34c & 99.9 & 60.0 & 106.2 & 51.4 & 88.4 & 80.6 \\
\hline GF35 & 94.9 & 91.7 & 110.4 & 65.4 & 110.1 & 108.0 \\
\hline GF36 & 108.2 & 93.8 & 112.4 & 61.5 & 134.2 & 92.8 \\
\hline GF36b & 98.5 & 97.9 & 101.6 & 99.0 & 92.9 & 88.9 \\
\hline GF36c & 103.2 & 103.8 & 102.7 & 102.9 & 101.1 & 92.2 \\
\hline GF37 & 96.8 & 111.4 & 111.3 & 107.3 & 139.9 & 109.1 \\
\hline GF37b & 101.3 & 101.8 & 105.2 & 97.7 & 99.4 & 109.6 \\
\hline GF38 & 104.8 & 98.3 & 105.9 & 105.8 & 98.5 & 109.6 \\
\hline GF40 & 85.2 & 60.1 & 94.1 & 61.1 & 103.6 & 103.4 \\
\hline GF41 & 101.9 & 65.5 & 94.4 & 93.8 & 157.2 & 101.7 \\
\hline
\end{tabular}

* Sulfate (S) is a calculation of $\mathrm{SO}_{4}$ from measured ICP-AES Sulfur analysis

Table 3-16. SRAT Product AD and PSAL Anion with Comparison to AD TOC, mg/kg

\begin{tabular}{|lcccc|}
\hline Analyte & GF36b & GF36c & GF37b & GF38 \\
\hline PSAL glycolate & 50,200 & 55,100 & 55,500 & 77,900 \\
\hline AD Glycolate & 33,900 & 34,400 & 35,900 & 54,500 \\
\hline PSAL Oxalate & 3,160 & 3,300 & 1,340 & 2,390 \\
\hline AD Formate & $<500$ & $<500$ & $<500$ & $<500$ \\
\hline PSAL Formate & $<100$ & $<100$ & $<100$ & $<100$ \\
\hline PSAL Calculated TOC & 20,900 & 24,100 & 24,100 & 32,400 \\
\hline AD Calculated TOC & 11,500 & 11,500 & 11,900 & 18,100 \\
\hline AD Measured TOC & 19,700 & 28,600 & 24,500 & 26,200 \\
\hline
\end{tabular}

\subsubsection{SRAT Condensate}

Samples collected during SRAT dewater, and the liquid remaining post SRAT in the MWWT and FAVC were analyzed. The results are summarized in Table 3-17 for the SRAT dewater, Table 3-18 for the MWWT and Table 3-19 for the FAVC. Note that no samples were analyzed for duplicate runs. 
Table 3-17. SRAT Dewater Composition, mg/L

\begin{tabular}{|ccccccc|}
\hline Analyte & GF34 & GF35 & GF36 & GF37 & GF40 & GF41 \\
\hline $\mathbf{C a}$ & 1.78 & 0.456 & 0.603 & 0.641 & $<10.0$ & $<10.0$ \\
\hline $\mathbf{C d}$ & $<0.100$ & $<0.100$ & $<0.100$ & $<0.100$ & $\mathrm{NM}$ & $\mathrm{NM}$ \\
\hline $\mathbf{H g}$ & $\mathrm{NM}$ & $\mathrm{NM}$ & $\mathrm{NM}$ & $\mathrm{NM}$ & 556 & 553 \\
\hline $\mathbf{K}$ & $<10.0$ & $<10.0$ & $<10.0$ & $<10.0$ & 15.85 & 16.45 \\
\hline $\mathbf{N a}$ & $\mathrm{NM}$ & $\mathrm{NM}$ & $\mathrm{NM}$ & $\mathrm{NM}$ & 30.0 & 105 \\
\hline $\mathbf{S i}$ & 99.0 & 8.68 & 25.9 & 220 & 1,100 & 1,660 \\
\hline $\mathbf{N O}_{3}{ }^{-}$ & 8,150 & 7,940 & 4,670 & 4,600 & 32,000 & 50,200 \\
\hline $\mathbf{S O}_{4}{ }^{2-}$ & 143 & 123 & $<100$ & $<100$ & 277 & $<100$ \\
\hline $\mathbf{C}_{2} \mathbf{O}_{4}{ }^{2-}$ & $<100$ & $<100$ & $<100$ & $<100$ & 278 & $<100$ \\
\hline $\mathbf{C}_{2} \mathbf{H}_{3} \mathbf{O}_{3}{ }^{-}$ & $<100$ & $<100$ & $<100$ & $<100$ & $<100$ & 118 \\
\hline $\mathbf{H C O}_{2}{ }^{-}$ & $<100$ & $<100$ & $<100$ & $<100$ & $<100$ & 179 \\
\hline Density, $\mathbf{g} / \mathbf{m L}$ & $\mathrm{NM}$ & $\mathrm{NM}$ & $\mathrm{NM}$ & $\mathrm{NM}$ & 1.0160 & 1.0101 \\
\hline pH (unitless) & $\mathrm{NM}$ & $\mathrm{NM}$ & $\mathrm{NM}$ & $\mathrm{NM}$ & 0.51 & 0.35 \\
\hline
\end{tabular}

Note: The following were less than detection limits: $\mathrm{Al}, \mathrm{B}, \mathrm{Ba}, \mathrm{Cd}, \mathrm{Cr}, \mathrm{Cu}, \mathrm{Fe}, \mathrm{Mg}, \mathrm{Mn}, \mathrm{Ni}, \mathrm{P}, \mathrm{Pb}$, $\mathrm{Pd}, \mathrm{Rh}, \mathrm{Ru}, \mathrm{S}, \mathrm{Ti}, \mathrm{Zn}, \mathrm{Zr}, \mathrm{F}^{-}, \mathrm{Cl}^{-}, \mathrm{NO}_{-}-\mathrm{HCO}_{2}^{-}$. NM is not measured.

Table 3-18. Post SRAT MWWT Composition

\begin{tabular}{|lcc|}
\hline Analyte & GF40 & GF41 \\
\hline $\mathrm{Ca}$ & 3.89 & 4.95 \\
\hline $\mathrm{Hg}$ & 36.6 & 61.8 \\
\hline $\mathrm{K}$ & 14.9 & 31.8 \\
\hline $\mathrm{Na}$ & 8.85 & 6.44 \\
\hline $\mathrm{Si}$ & 606 & 957 \\
\hline $\mathrm{NO}_{3}^{-}$ & 22,000 & 21,400 \\
\hline Density & 1.0058 & 1.0059 \\
\hline pH & 0.74 & 0.75 \\
\hline
\end{tabular}

Note: The following were less than detection limits: $\mathrm{Al}, \mathrm{Cr}, \mathrm{Cu}, \mathrm{Fe}, \mathrm{Mg}, \mathrm{Mn}, \mathrm{Ni}, \mathrm{P}, \mathrm{S}, \mathrm{Ti}, \mathrm{Zn}, \mathrm{Zr}$, $\mathrm{NO}_{2}{ }^{-}, \mathrm{SO}_{4}{ }^{2 \cdot}, \mathrm{C}_{2} \mathrm{O}_{4}{ }^{2-}, \mathrm{HCO}_{2}{ }^{-}$

Table 3-19. Post SRAT FAVC Composition

\begin{tabular}{|ccc|}
\hline Analysis & $\mathbf{G F 4 0}$ & $\mathbf{G F 4 1}$ \\
\hline $\mathrm{NO}_{2}^{-}$ & $<100$ & $<100$ \\
\hline $\mathrm{NO}_{3}{ }^{-}$ & 213,000 & 192,000 \\
\hline $\mathrm{SO}_{4}{ }^{2-}$ & $<100$ & 144 \\
\hline $\mathrm{HCO}_{2}^{-}$ & $<100$ & $<100$ \\
\hline $\mathrm{C}_{2} \mathbf{O}_{4}{ }^{-2}$ & 234 & 171 \\
\hline $\mathrm{C}_{2} \mathbf{H}_{3} \mathbf{O}_{3}^{-}$ & $<100$ & $<100$ \\
\hline
\end{tabular}

Note: The following were less than detection limits: $\mathrm{F}^{*}, \mathrm{Cl}^{-}$ 


\subsubsection{Nitrogen Balance}

A nitrogen balance was completed for GF41. In this balance, it is assumed that the nitrogen in air does not participate in any reactions. As a result, the nitrogen in the slurry as nitrate and nitrite, the nitrate in the ammonia scrubber solution, the added nitrate from the nitric acid, the nitrate present in the SRAT product, ammonia scrubber solution and condensate (dewater, MWWT, and FAVC), and the nitrogen from the measured $\mathrm{NO}, \mathrm{NO}_{2}$, and $\mathrm{N}_{2} \mathrm{O}$. The total balance has 0.363 moles $\mathrm{N}_{2}$ more than was added to the original sludge ( $1.6 \%$ more nitrate post run). The balance is summarized below in Table 3-20. Note that the nitrite is completely destroyed producing nitrate in the SRAT product ( $42 \%$ of nitrite), condensate ( $26 \%$ of nitrite), and ammonia scrubber solution $(24 \%$ of nitrite). A smaller contribution comes from the $\mathrm{NO}, \mathrm{NO}_{2}$, and $\mathrm{N}_{2} \mathrm{O}$ in the offgas ( $15 \%$ of nitrite).

Table 3-20. GF41 Nitrogen Balance

\begin{tabular}{|lrrrr|}
\hline & \multicolumn{4}{c|}{ Moles N } \\
\hline Slurry Nitrite & 1.040 & 0.000 & 0.000 & -1.040 \\
\hline Slurry Nitrate & 0.492 & 2.677 & 3.601 & 0.432 \\
\hline Nitrate in Condensate & 0.000 & 0.000 & 0.272 & 0.272 \\
\hline Nitrate in Scrubber & 0.011 & 0.000 & 0.261 & 0.250 \\
\hline $\mathbf{N}_{2} \mathbf{O}$ in offgas & 0.000 & 0.000 & 0.035 & 0.035 \\
\hline $\mathrm{NO}_{\text {in } \text { offgas }}$ & 0.000 & 0.000 & 0.091 & 0.091 \\
\hline $\mathrm{NO}_{2}$ in offgas & 0.000 & 0.000 & 0.032 & 0.032 \\
\hline NH3 in Scrubber & 0.000 & 0.000 & 0.007 & 0.007 \\
\hline Total & 1.544 & 2.677 & 4.292 & 0.071 \\
\hline
\end{tabular}

\subsubsection{Other SRAT Data}

Other SRAT product data are summarized in Table 3-21. 
Table 3-21. Other SRAT Product Data

\begin{tabular}{|lcccccccc|}
\hline Run & $\begin{array}{c}\text { Total } \\
\text { Solids, } \\
\text { wt } \%\end{array}$ & $\begin{array}{c}\text { Insoluble } \\
\text { Solids, } \\
\text { wt } \%\end{array}$ & $\begin{array}{c}\text { Calcined } \\
\text { Solids, } \\
\text { wt } \%\end{array}$ & $\begin{array}{c}\text { Soluble } \\
\text { Solids, } \\
\text { wt } \%\end{array}$ & $\mathbf{p H}$ & $\begin{array}{c}\text { Slurry } \\
\text { Density, } \\
\text { g/mL }\end{array}$ & $\begin{array}{c}\text { Supernate } \\
\text { Density, } \\
\mathbf{g} / \mathbf{m L}\end{array}$ & $\begin{array}{c}\mathbf{N H} \\
\mathbf{m g} / \mathbf{L}\end{array}$ \\
\hline GF34 & 31.5 & 17.7 & 18 & 13.8 & 4.35 & 1.25 & 1.11 & 30 \\
\hline GF34b & 27.3 & 14.2 & 15.4 & 15.2 & 3.58 & 1.20 & 1.10 & NM \\
\hline GF34c & 27.3 & 13.7 & 15.3 & 15.7 & 3.38 & 1.19 & 1.11 & NM \\
\hline GF35 & 29.6 & 17.7 & 17.6 & 12.0 & 6.85 & 1.23 & 1.10 & 9 \\
\hline GF36 & 30.3 & 17 & 16.7 & 13.3 & 4.22 & 1.21 & 1.11 & 18 \\
\hline GF36b & 27.6 & 13.7 & 15.0 & 13.9 & 4.05 & 1.20 & 1.11 & NM \\
\hline GF36c & 27.7 & 13.3 & 15.1 & 14.4 & 4.23 & 1.21 & 1.11 & NM \\
\hline GF37 & 29.7 & 14.9 & 16.1 & 14.8 & 4.32 & 1.21 & 1.11 & 20 \\
\hline GF37b & 28.1 & 13.4 & 15.1 & 14.8 & 4.28 & 1.20 & 1.11 & NM \\
\hline GF38 & 27.9 & 12.4 & 14.0 & 15.5 & 3.47 & 1.20 & 1.12 & $\mathrm{NM}$ \\
\hline GF40 & 27.6 & 10.2 & 14.4 & 17.4 & 4.84 & 1.21 & 1.13 & $<10$ \\
\hline GF41 & 27.6 & 7.53 & 13.7 & 20.1 & 5.01 & 1.22 & 1.15 & $<10$ \\
\hline
\end{tabular}

Ammonia was below detection limit of $5 \mathrm{mg} / \mathrm{L}$ in ammonia scrubber samples. SRAT products were slightly above the detection limit (Table 3-21) as were some SME products, though the concentrations were smaller.

\subsubsection{SME Data}

SME data is discussed in this section.

\subsubsection{SME Elemental Data}

General SME product sample data for the four runs (GF34, GF35, GF36 and GF37 had SME cycles) are tabulated below. The waste loading for these runs was targeted at $36 \%$ using frit 418 . Elemental analyses were completed of both the slurry and supernate from all SME products. The slurry results are summarized in Table 3-22. Conversion of the elemental data to the expected oxide form allows summing the oxides as a measure of both complete sample dissolution and accurate analysis of the major elements in the sludge product. The sum of oxides range for 98.6-100.5 over this data set (95-105 is considered acceptable). The slurry samples were filtered and the supernate results of these analyses are summarized in Table 3-23. 
Table 3-22. SME Product Slurry Elemental Data, wt \% calcined solids basis

\begin{tabular}{|ccccccc|}
\hline Run & GF34 & GF35 & GF36 & GF37 & GF40 & GF41 \\
\hline $\mathbf{A l}$ & 3.35 & 5.47 & 3.4 & 9.00 & 5.06 & 5.03 \\
\hline $\mathbf{B}$ & 1.32 & 1.40 & 1.30 & 1.30 & 1.50 & 1.59 \\
\hline $\mathbf{B a}$ & 0.031 & 0.041 & 0.036 & 0.026 & 0.027 & 0.023 \\
\hline $\mathbf{C a}$ & 1.28 & 0.25 & 0.680 & 0.651 & 0.304 & 0.300 \\
\hline $\mathbf{C d}$ & $<0.010$ & $<0.010$ & $<0.010$ & $<0.010$ & $\mathrm{NM}$ & $\mathrm{NM}$ \\
\hline $\mathbf{C r}$ & 0.016 & 0.037 & 0.119 & 0.103 & 0.017 & 0.016 \\
\hline $\mathbf{C u}$ & 0.035 & 0.037 & 0.035 & 0.029 & 0.013 & 0.015 \\
\hline $\mathbf{F e}$ & 11.8 & 7.4 & 11.9 & 4.85 & 4.08 & 3.45 \\
\hline $\mathbf{K}$ & 0.063 & 0.048 & 0.041 & 0.049 & 0.174 & 0.173 \\
\hline $\mathbf{L i}$ & 2.20 & 2.31 & 2.27 & 2.18 & $\mathrm{NM}$ & $\mathrm{NM}$ \\
\hline $\mathbf{M g}$ & 0.152 & 0.145 & 0.924 & 0.858 & 0.115 & 0.102 \\
\hline $\mathbf{M n}$ & 1.44 & 1.79 & 0.231 & 0.220 & 1.35 & 1.13 \\
\hline $\mathbf{N a}$ & 8.60 & 9.23 & 8.60 & 9.06 & 11.2 & 10.8 \\
\hline $\mathbf{N i}$ & 0.073 & 1.21 & 1.00 & 0.92 & 0.58 & 0.49 \\
\hline $\mathbf{P}$ & $<0.100$ & $<0.100$ & $<0.100$ & $<0.100$ & $<0.100$ & $<0.100$ \\
\hline $\mathbf{P b}$ & 0.038 & 0.014 & 0.036 & 0.035 & $<0.100$ & $<0.100$ \\
\hline $\mathbf{P d}$ & $<0.100$ & $<0.100$ & $<0.100$ & $<0.100$ & $<0.100$ & $<0.100$ \\
\hline $\mathbf{R h}$ & 0.017 & 0.018 & 0.027 & 0.025 & $<0.100$ & $<0.100$ \\
\hline $\mathbf{R u}$ & 0.015 & 0.024 & 0.034 & 0.023 & $<0.100$ & $<0.100$ \\
\hline $\mathbf{S}$ & 0.099 & 0.116 & 0.102 & 0.114 & 0.075 & 0.082 \\
\hline $\mathbf{S i}$ & 23.35 & 24.3 & 23.45 & 22.9 & 25.0 & 26.2 \\
\hline $\mathbf{S n}$ & $<0.010$ & 0.013 & 0.044 & 0.038 & $\mathrm{NM}$ & $\mathrm{NM}$ \\
\hline $\mathbf{T i}$ & 0.007 & 0.013 & 0.012 & 0.008 & 0.064 & 0.066 \\
\hline $\mathbf{Z n}$ & 0.026 & 0.027 & 0.028 & 0.026 & 0.017 & 0.016 \\
\hline $\mathbf{Z r}$ & 0.026 & 0.103 & 0.051 & 0.024 & 0.182 & 0.173 \\
\hline & & & & & & \\
\hline
\end{tabular}


Table 3-23. SME Product Supernate Elemental Data, mg/L supernate basis

\begin{tabular}{|c|c|c|c|c|c|c|}
\hline Run & GF34 & GF35 & GF36 & GF37 & GF40 & GF41 \\
\hline Al & 178 & 343 & 320 & 922 & 2,240 & 2,680 \\
\hline B & 54.0 & 55.0 & 48.0 & 47.2 & $<10.0$ & $<10.0$ \\
\hline $\mathrm{Ba}$ & 2.22 & 1.06 & 1.68 & 1.35 & 14.3 & 16.5 \\
\hline $\mathrm{Ca}$ & 2,090 & 169 & 2,110 & 1,960 & 399 & 419 \\
\hline Cd & $<0.010$ & $<0.010$ & $<0.010$ & $<0.010$ & $\overline{\mathrm{NM}}$ & NM \\
\hline $\mathrm{Cr}$ & 1.93 & 7.03 & 34.6 & 69.4 & 35.3 & 37.7 \\
\hline $\mathrm{Cu}$ & 5.82 & 3.16 & 12.8 & 16.7 & 27.0 & 28.8 \\
\hline $\mathrm{Fe}$ & 1,280 & 326 & 1,200 & 973 & 10,100 & 12,250 \\
\hline $\mathrm{K}$ & 396 & 311 & 252 & 212 & 991 & 1,095 \\
\hline La & 18.2 & 10.2 & 17.6 & 36.6 & $\overline{\mathrm{NM}}$ & NM \\
\hline $\mathbf{L i}$ & 2670 & 216 & 234 & 183 & 352 & 376 \\
\hline $\mathrm{Mg}$ & 315 & 223 & 4,660 & 3,460 & 5,230 & 4,680 \\
\hline Mn & 8,610 & 3,620 & 1,280 & 998 & 46,300 & 52,800 \\
\hline $\mathrm{Na}$ & 29,500 & 37,000 & 24,750 & 25,500 & 46,300 & 52,800 \\
\hline $\mathrm{Ni}$ & 114 & 226 & 2,800 & 2,490 & 1,070 & 868 \\
\hline $\mathbf{P}$ & 0.77 & 2.49 & 1.02 & 1.87 & 10.2 & 10.8 \\
\hline $\mathbf{P b}$ & 4.01 & 0.30 & 0.81 & 2.01 & 15.7 & 19.1 \\
\hline Pd & 0.18 & 0.24 & 0.14 & 0.13 & $<1.00$ & $<1.00$ \\
\hline $\mathbf{R h}$ & 2.83 & 12.2 & 12.6 & 7.95 & 36.7 & 37.9 \\
\hline $\mathbf{R u}$ & 86.8 & 35.3 & 166 & 205 & 85 & 97 \\
\hline $\mathrm{S}$ & 679 & 874 & 575 & 516 & 715 & 755 \\
\hline $\mathrm{Si}$ & 30.6 & 102 & 27.6 & 71.5 & 62.3 & 86.7 \\
\hline $\mathrm{Sr}$ & 4.22 & 2.67 & 3.05 & 2.77 & NM & NM \\
\hline $\mathrm{Ti}$ & $<0.010$ & $<0.010$ & $<0.010$ & $<0.010$ & 0.938 & 1.194 \\
\hline $\mathrm{Zn}$ & 20.6 & 2.40 & 28.4 & 17.0 & 41.9 & 44.2 \\
\hline $\mathrm{Zr}$ & 5.25 & 38.0 & 32.1 & 22.2 & 261 & 258 \\
\hline
\end{tabular}

\subsubsection{SME Anion Data}

Ion Chromatography was completed for both the slurry and supernate from all SME products. The slurry results are summarized in Table 3-24. The slurry samples were filtered and the supernate results of these analyses are summarized in Table 3-25. Anion balance data for nitrite, nitrate, formate and glycolate are presented in the table below for all runs (Table 3-26).

The anion data is inconsistent. For example, in Run GF37, the data indicates there was high nitrite to nitrate conversion in the SRAT and high nitrate loss in the SME. Also, it indicates that glycolate was destroyed in the SRAT and generated in the SME. It is more likely that there was a lower nitrite to nitrate conversion and lower glycolate loss in the SRAT with minimal nitrate and glycolate loss in the SME. The inconsistent results is likely due to fouling of the IC columns by metals and oxalate that are soluble at $\mathrm{pH} 4$ but insoluble at $\mathrm{pH} 10$ (approximately sample of eluent). It is recommended that removal of metals with an appropriate guard column be considered. An anion round robin has been initiated to resolve the issues with the analytical technique. 
Table 3-24. SME Product Slurry Anion Data, mg/kg Slurry Basis

\begin{tabular}{|ccccccc|}
\hline Run & GF34 & GF35 & GF36 & GF37 & GF40 & GF41 \\
\hline Chloride & 525 & 445 & 494 & 821 & 500 & 500 \\
\hline Nitrite & $<100$ & $<100$ & $<100$ & $<100$ & $<100$ & $<100$ \\
\hline Nitrate & 43,650 & 34,750 & 43,650 & 56,550 & 48,200 & 41,700 \\
\hline Sulfate & 1,060 & 1,470 & 1,000 & 1,500 & 1,780 & 1,220 \\
\hline Oxalate & 1,670 & 3,290 & 4,150 & 2,755 & 17,000 & 13,300 \\
\hline Glycolate & 37,250 & 30,750 & 28,200 & 42,200 & 49,150 & 48,600 \\
\hline Formate & 1,405 & 2,330 & 1,720 & $<100$ & $<100$ & $<100$ \\
\hline Phosphate & $<100$ & $<100$ & $<100$ & $<100$ & $<100$ & $<100$ \\
\hline
\end{tabular}

Table 3-25. SME Product Filtrate Anion Data, mg/L Supernate Basis

\begin{tabular}{|ccccccc|}
\hline Run & GF34 & GF35 & GF36 & GF37 & GF40 & GF41 \\
\hline Formate & $<100$ & $<100$ & $<100$ & $<100$ & $<500$ & $<500$ \\
\hline Chloride & 892 & 770 & 884 & 726 & $<500$ & $<500$ \\
\hline Nitrite & $<100$ & $<100$ & $<100$ & $<100$ & $<500$ & $<500$ \\
\hline Nitrate & 79,100 & 58,200 & 84,750 & 60,100 & 94,000 & 84,000 \\
\hline Sulfate & 2,345 & 2,825 & 2,710 & 2,570 & 2,330 & 2,540 \\
\hline Oxalate & 1,620 & 4,845 & 3,960 & 3,395 & 10,400 & 13,500 \\
\hline Glycolate & 59,400 & 42,150 & 45,550 & 45,600 & 60,400 & 58,500 \\
\hline Formate & 1,715 & 3,785 & 2,251 & 1,940 & $<500$ & $<500$ \\
\hline Phosphate & $<100$ & $<100$ & $<100$ & $<100$ & $<500$ & $<500$ \\
\hline
\end{tabular}

Table 3-26. SME Anion Balance Data, \%

\begin{tabular}{|lccccccc|}
\hline & GF34 & GF35 & GF36 & GF37 & GF40 & GF41 \\
\hline SME Nitrate Destruction & 9.9 & -2.5 & 10.1 & 21.8 & 6.5 & 15.6 \\
\hline SME Glycolate Destruction & 5.3 & 15.1 & 4.9 & 35.8 & 22.2 & 14.3 \\
\hline SME Formate Destruction & 41.5 & 61.8 & 42.6 & 62.2 & 0.0 & 0.0 \\
\hline
\end{tabular}

\subsubsection{SME Condensate}

The SME condensate was not analyzed for GF34-38. However, GF40 and GF41 SME condensate samples were collected. Each sample was analyzed for elementals via ICP-AES, and anions via IC. The condensate was very low in anions and cations. The largest component is the silicon, likely an antifoam degradation product, not frit, as the same concentration was seen in the SRAT condensate. Note also that the $\mathrm{pH}$ of the SME condensate is considerably higher than the SRAT condensate. The SME dewater results are summarized in Table 3-27. 
SRNL-STI-2012-00018

Revision 1

Table 3-27. SME Condensate, $\mathrm{mg} / \mathrm{L}$

\begin{tabular}{|ccc|}
\hline Analyte & GF40 & GF41 \\
\hline $\mathbf{H g}$ & 24.6 & 15.4 \\
\hline $\mathbf{K}$ & 14.6 & 14.5 \\
\hline $\mathrm{Na}$ & 15.3 & 8.62 \\
\hline $\mathrm{Si}$ & 1,455 & 553 \\
\hline $\mathrm{Ti}$ & $<1.00$ & $<1.00$ \\
\hline $\mathrm{NO}_{3}^{-}$ & 329 & 125 \\
\hline Density & 0.9976 & 0.9970 \\
\hline $\mathbf{p H}$ & 3.28 & 3.39 \\
\hline
\end{tabular}

Note: The following were less than detection limits: $\mathrm{Al}, \mathrm{Ca}, \mathrm{Cr}, \mathrm{Cu}, \mathrm{Fe}, \mathrm{Mg}, \mathrm{Mn}, \mathrm{Ni}, \mathrm{P}, \mathrm{S}, \mathrm{Ti}, \mathrm{Zn}$, $\mathrm{Zr}, \mathrm{NO}_{2}{ }^{-}, \mathrm{SO}_{4}{ }^{2-}, \mathrm{C}_{2} \mathrm{O}_{4}{ }^{2-}, \mathrm{C}_{2} \mathrm{H}_{3} \mathrm{O}_{3}{ }^{-}, \mathrm{HCO}_{2}{ }^{-}$

\subsubsection{Other SME Data}

Other SME product data are summarized in the Table 3-28. Of particular note is that the GF37 SME was not completed prior to kettle breakage. As a result, the total solid result of the recovered product is significantly lower than had been targeted. Also, no analyses were completed on the SME condensate from Runs GF34-GF37.

Table 3-28. Other SME Product Data

\begin{tabular}{|lrrrrrr|}
\hline Run & GF34 & GF35 & GF36 & GF37 & GF40 & GF41 \\
\hline Total Solids, wt $\%$ & 48.8 & 46.3 & 45.8 & 39.3 & 49.8 & 54.0 \\
\hline Insoluble Solids, wt\% & 37.9 & 37.6 & 35.3 & 29.7 & 36.9 & 41.0 \\
\hline Calcined Solids, wt\% & 38.5 & 37.3 & 35.8 & 29.7 & 38.0 & 42.9 \\
\hline Soluble Solids, wt\% & 10.9 & 8.71 & 10.5 & 9.53 & 12.9 & 13.0 \\
\hline pH & 4.66 & 6.18 & 4.39 & 4.31 & 4.76 & 4.81 \\
\hline Slurry Density, g/mL & 1.42 & 1.34 & 1.38 & 1.29 & 1.137 & 1.150 \\
\hline Supernate Density, g/mL & 1.11 & 1.10 & 1.10 & 1.09 & 1.243 & 1.234 \\
\hline Ammonium, $\mathbf{m g / L}$ & 14 & $<5$ & $<5$ & 7 & $<10$ & $<10$ \\
\hline
\end{tabular}

Note: GF40 and GF41 SME products were too thin and the frit settled quickly. It was difficult to maintain a uniform mixture. Higher total solid targets are recommended in future processing of underwashed sludges as significantly less insoluble solids are present in the SME product, as the sodium is included in the waste loading calculation.

\subsubsection{Supernate Chemistry -- Dissolution of Metals and Solubility of Anions}

One of the major unknowns revolving around the glycolic flowsheet is what is happening to the anions and cations during and after processing. The addition of glycolic acid and the ability to keep the $\mathrm{pH}$ low throughout SRAT and SME processing combine to dissolve insoluble metal species leading to higher concentrations of metals in solution. However in these runs, we have also seen crystalline solids form during storage, after the SRAT and SME cycles were complete. A photo below (Figure 3-17) shows the solids formation in some of the SRAT products. 


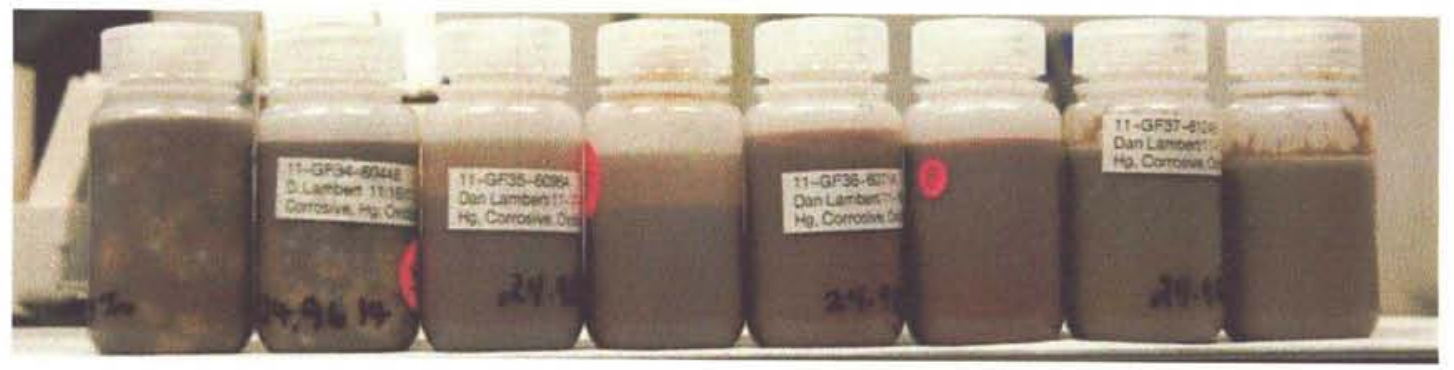

Figure 3-17. Photo of SRAT Product Samples 11/30/2011 (4 days after SME cycle)

It should be noted that the solids formed primarily on the surface of the sample bottle and were easily reincorporated into the slurry by gentle mixing. The samples from GF34, GF35, GF36 and GF37 SRAT and SME products were submitted to SRNL/AD and identified as Gibbsite $(\gamma-$ $\left.\mathrm{Al}(\mathrm{OH})_{3}\right)$, Quartz $\left(\mathrm{SiO}_{2}\right)$, Bayerite $\left(\alpha-\mathrm{Al}(\mathrm{OH})_{3}\right)$, Boehmite $(\gamma-\mathrm{AlO}(\mathrm{OH}))$, and Goethite $(\alpha-\mathrm{FeOOH})$. Note that there were no crystals noted in the GF35 (SB7A) simulant, only in some of the matrix simulants. The X-ray Diffraction (XRD) results are summarized in Appendix C.

\subsubsection{SRAT Supernate Chemistry}

The composition of the SRAT product slurry and supernate anions is summarized in Table 3-12, Table 3-13. SRAT Product Filtrate PSAL Anion Data, mg/L Supernate Basis and Table 3-14. Figure 3-18 and Figure 3-19 show the amount of each element found in the SRAT product supernate expressed as a percentage of the total element present. These data are calculated by dividing the supernate concentration (converted to $\mathrm{mg} / \mathrm{kg}$ on a slurry basis) by the total slurry fraction of each element (converted to $\mathrm{mg} / \mathrm{kg}$ ). Numbers greater than $100 \%$ are not physically possible and are a result of error in one of the analytical measurements used in the calculation.

The $\%$ solubility of each anion is approximately $100 \%$ ( $80-120 \%$ based on method uncertainty), except for oxalate, which had a solubility of approximately $60 \%$ in the GF34 and GF35 runs. The solubility of $\mathrm{Al}$ and $\mathrm{Fe}$ was low in all runs. The solubility of $\mathrm{Na}, \mathrm{Mg}$, and $\mathrm{Mn}$ are all high in the glycolic flowsheet runs. For most of the metals, which are present primarily as hydroxides and oxides in the sludge, the concentration in the supernate increases throughout the SRAT cycle, but appear to be constant by the end of the SRAT cycle. Samples were pulled at the completion of nitric acid addition, midway through glycolic acid addition, after completing glycolic acid addition, onehour into dewater, post dewater, 4 hours into reflux and 8 hours into reflux. These samples were centrifuged soon after being pulled to make sure no further reactions occurred due to insoluble solids. One interesting observation is that the centrifuged GF37b samples $(100 \%$ acid stoichiometry) had almost no supernate after centrifuging at the completion of dewater $(0.3 \mathrm{~g}$ of supernate typical in these samples). Prior to dewater and throughout run GF38 approximately 6-7 $\mathrm{g}$ of supernate was easily removed after centrifuging.

Based on this data, the order of dissolution for the "major components" is: $\mathrm{Hg}>\mathrm{Ca}>\mathrm{Mn}>\mathrm{Ni}>\mathrm{Mg}>\mathrm{Al}>\mathrm{Fe}$. The data is summarized for major metals $(>1,000 \mathrm{~g} / \mathrm{L})$ in Figure 3-18 and minor metals in Figure 3-19. The graphs show the approach to maximum solubility, defined as $100 \%$ for each element on these graphs. This does not indicate that $100 \%$ of these individual elements went into solution during processing. 
SRNL-STI-2012-00018

Revision 1

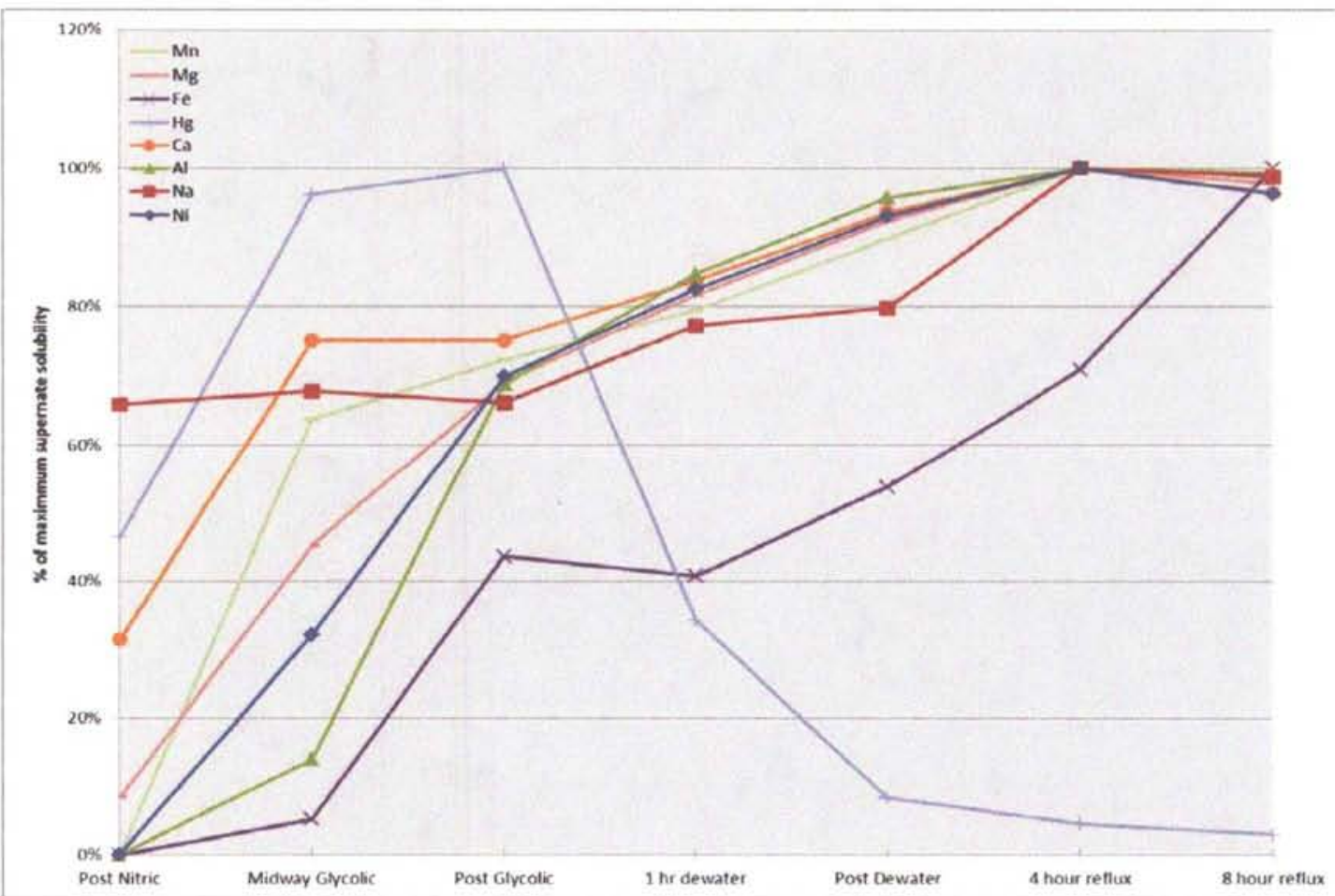

Figure 3-18. Order of Dissolution of "Major Metals" During SRAT Processing

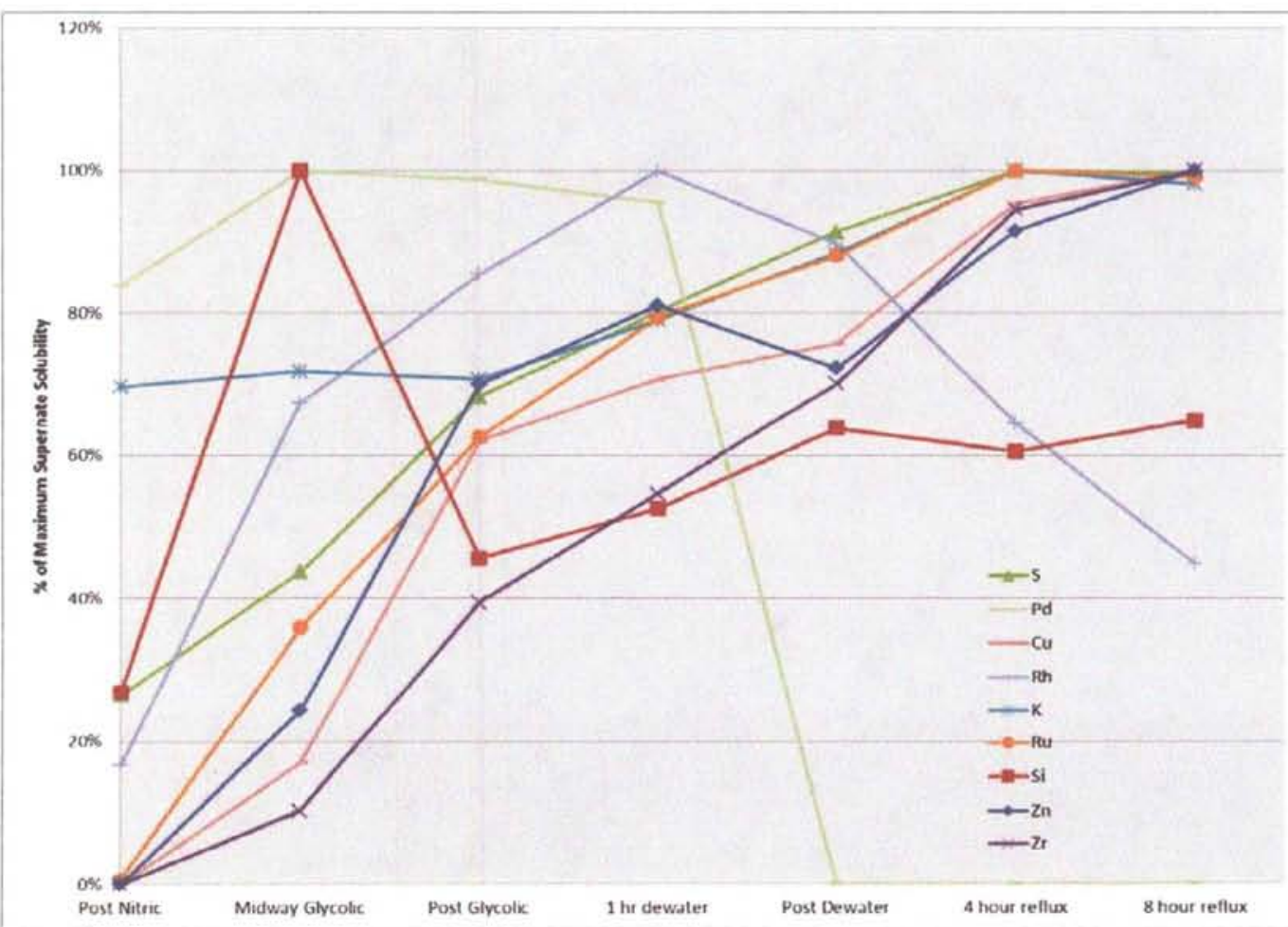

Figure 3-19. Order of Dissolution of "Minor Metals" During SRAT Processing 
Several metals are of particular interest during SRAT processing. Note that mercury is discussed in Section 3.2.2. The reduction of $\mathrm{Mn}$ is important especially in the melter and cold cap in order to minimizing foaming in the melter. As can be seen in Figure 3-18, the Mn is dissolved (and likely reduced) early in the SRAT cycle and is $>90 \%$ of the maximum solubility by the end of dewater. There are several metals that are essentially totally soluble such as $\mathrm{Na}, \mathrm{K}$, and $\mathrm{Ca}$. The concentration of each metal changes as the metal is first diluted during acid addition, then concentrated during the dewater phase. In addition, the concentration of soluble metals should remain constant throughout the post dewater stage of the SRAT cycle. In GF37b, the concentration of both $\mathrm{Na}$ and $\mathrm{Ca}$ increased during this time, likely due to the extended centrifuge time necessary to squeeze out the $0.3 \mathrm{~g}$ of supernate from a $15 \mathrm{~mL}$ centrifuge tube. Note that for the lower acid run, GF37b, the calcium was not completely soluble until midway through glycolic acid. This may indicate that it may take more than $100 \%$ acid stoichiometry to produce a SRAT product that is easily concentrated in the SME.

In order to understand the dissolution of metals and the timing of their dissolution, additional samples were pulled during runs GF37b and GF38 (LoFeLoMn sludge). The dissolution of $\mathrm{Hg}$ is discussed in the mercury section.

\subsubsection{SME Supernate Chemistry}

The main change in supernate chemistry during the SME cycle is that formic acid is added to the frit slurry to prevent caking. Formic acid is very reactive in DWPF SRAT and SME processing, ultimately leading to the noble metal catalyzed decomposition to hydrogen and $\mathrm{CO}_{2}$. No formic acid was added or detected during the SRAT cycle. The solubility of the anions during the SME cycle is summarized in Table 3-29.

Table 3-29. Major Components: SME Product \% of Anion Soluble

\begin{tabular}{|lrrrrrrr|}
\hline Run & \multicolumn{1}{c}{ GF34 } & \multicolumn{1}{l}{ GF35 } & \multicolumn{1}{l}{ GF36 } & \multicolumn{1}{c}{ GF37 } & \multicolumn{1}{c}{ GF40 } & \multicolumn{1}{c|}{ GF41 } \\
\hline Formate & 68.1 & 92.5 & 76.7 & 67.4 & NA & NA \\
\hline Glycolate & 89.0 & 78.1 & 94.6 & 95.8 & 62.4 & 57.6 \\
\hline Nitrate & 101 & 95.4 & 114 & 101 & 99.0 & 96.5 \\
\hline Oxalate & 54.1 & 83.9 & 55.9 & 77.4 & 31.1 & 48.6 \\
\hline Sulfate & 123 & 109 & 159 & 136 & 66.4 & 99.7 \\
\hline Sulfate (S) & 98.9 & 115.0 & 91.9 & 98.4 & 128 & 103 \\
\hline
\end{tabular}

* Sulfate (S) is a calculation of $\mathrm{SO}_{4}$ from measured ICP-AES Sulfur analysis

Frit 418 , nominally containing $8 \% \mathrm{~B}_{2} \mathrm{O}_{3}, 8 \% \mathrm{Li}_{2} \mathrm{O}, 8 \% \mathrm{Na}_{2} \mathrm{O}$, and $76 \% \mathrm{SiO}_{2}$, is added in the SME cycle. The added frit components are very insoluble, with the concentration of $\mathrm{B}, \mathrm{Li}$ and $\mathrm{Si}<1 \%$ in the six SME cycles. In addition, the Na solubility drops from near $100 \%$ in the SRAT cycle to 50 $60 \%$ by the time the SME cycle is complete due to the insoluble sodium in the frit. The solubility of the elements is summarized in Table 3-30. Note that the solubility of aluminum and iron are much higher and the solubility of magnesium and manganese are lower in the underwashed sludges (GF40 and GF41) compared to the matrix sludges (GF34-GF37). 
SRNL-STI-2012-00018

Revision 1

Table 3-30. Major Components: SME Product \% of Element Dissolved

\begin{tabular}{|lccccc|}
\hline Run & Al & Fe & Na & Mg & Mn \\
\hline GF34 HiFeHiMn & 0.8 & 1.6 & 49.5 & 30.0 & 86.7 \\
\hline GF35SB7A & 1.0 & 0.7 & 61.1 & 23.4 & 30.8 \\
\hline GF36 HiFeLoMn & 1.5 & 1.7 & 47.3 & 82.6 & 90.8 \\
\hline GF37 LoFeLoMn & 2.2 & 4.4 & 61.2 & 87.5 & 98.5 \\
\hline GF40 & 5.9 & 33.1 & 55.3 & 41.0 & 51.6 \\
\hline GF41 & 6.0 & 39.7 & 54.6 & 41.2 & 46.3 \\
\hline
\end{tabular}

\subsubsection{Post Processing Supernate Chemistry}

The formation of crystals in some of the SRAT and SME products could have been caused by continuing reactions after completion of CPC simulations or by changes in solubility caused by the lower temperature during storage. The addition of nitric and glycolic acid may have dissolved some species (i.e. $\mathrm{Al}$ and $\mathrm{Fe}$ ) to solubility at $102^{\circ} \mathrm{C}$, then the species became supersaturated upon cooling $\left(15-20^{\circ} \mathrm{C}\right)$. Crystal growth can be slow or fast. If crystal growth is fast, the crystals found have likely peaked, whereas with flow crystal growth the crystals can continue increasing.

\subsubsection{Improved Understanding of Supernate Chemistry}

OLI software has become the industry standard for simulation of electrolyte systems. However, the OLI database lacks many of the components needed to simulate the electrolyte systems in a SRAT or SME product. As a result, DWPF ${ }^{20}$ has requested that OLI "Update OLI database to include glycolate species and validate updated database against the latest SRNL test data".

The solubilities of all components are needed to evaluate the capability of OLI to predict solubility. The change in solubility over time will also be useful because the trend versus time will give an indication of kinetic effects (OLI ignores kinetics and assumes equilibrium in its calculations). However, if a component remains soluble for a short time (compared to the equilibrium assumption), it may remain soluble until fed to the melter.

A much more rigorous data collection program will be needed to compare the OLI predictions to sample results. It is useful to know the solubility of metals as a function of temperature to validate the OLI models. Supernate samples taken at temperature by the centrifuge method should be analyzed for total metals and dissolved metals. In addition, the temperature of the supernate when removed from the centrifuge tube should be recorded to determine the solubility at that temperature. The time between taking samples and analyzing them should be recorded and noting whether there are changes in the solubility versus time. Other data needed includes concentrations of dissolved anions including carbonate, concentrations of undissolved anions (including oxalate, sulfate, and phosphate), concentrations of metal cations, $\mathrm{pH}$ and the temperature $\mathrm{pH}$ was taken.

In addition, it is necessary to understand whether changes are occurring during storage. Crystals were noted in several early runs that had been over-concentrated. Periodic analysis of SRAT and SME products is needed to understand the kinetics of any crystal growth during storage.

\subsubsection{SRAT and SME Rheology}

Flow curves for the four initial SRAT and SME slurry products were obtained by using a Haake RS600 rheometer and the current DWPF simulant rheology protocol. ${ }^{21}$ The up and down curves were fit to a Bingham plastic model to determine yield stress and consistency. Down flow curve 
data are the generally preferred choice for comparisons between systems. The data for all runs are tabulated below for the SRAT (Table 3-31) and SME (Table 3-32).

Table 3-31. SRAT Product Rheology Summary

\begin{tabular}{|lccccc|}
\hline $\begin{array}{l}\text { SRAT Product } \\
\text { Sludge Type }\end{array}$ & $\begin{array}{c}\text { Wt \% } \\
\text { Insoluble } \\
\text { Solids }\end{array}$ & $\begin{array}{c}\text { Up } \\
\text { Yield Stress, } \\
\text { Pa }\end{array}$ & $\begin{array}{c}\text { Down } \\
\text { Yield Stress, } \\
\text { Pa }\end{array}$ & $\begin{array}{c}\text { Up } \\
\text { Consistency, } \\
\text { cP }\end{array}$ & $\begin{array}{c}\text { Down } \\
\text { Consistency, } \\
\text { cP }\end{array}$ \\
\hline DWPF Ranges & $10-15$ & 1.5 to 5 & 1.5 to 5 & 5 to 12 & 5 to 12 \\
\hline GF34 Hi Fe-Hi Mn & 17.7 & 1.9 & 1.9 & 11.7 & 11.7 \\
\hline GF35 Lo Fe-Hi Mn & 17.7 & 0.3 & 0.3 & 5.7 & 5.8 \\
\hline GF36 Hi Fe-Lo Mn & 17.0 & 3.7 & 3.6 & 16.2 & 16.8 \\
\hline GF37 Lo Fe-Lo Mn & 14.9 & 10.8 & 11.0 & 13.4 & 13.0 \\
\hline GF40 1.6 M Na & 10.2 & 0.15 & 0.10 & 3.05 & 3.09 \\
\hline GF41 1.9 M Na & 7.53 & 0.08 & 0.03 & 3.00 & 3.04 \\
\hline
\end{tabular}

Table 3-32. SME Product Rheology Summary

\begin{tabular}{|cccccc|}
\hline Sludge Type & $\begin{array}{c}\text { Wt \% } \\
\text { Insoluble } \\
\text { Solids }\end{array}$ & $\begin{array}{c}\text { Up } \\
\text { Yield Stress, } \\
\text { Pa }\end{array}$ & $\begin{array}{c}\text { Down } \\
\text { Yield Stress, } \\
\text { Pa }\end{array}$ & $\begin{array}{c}\text { Up } \\
\text { Consistency, } \\
\text { cP }\end{array}$ & $\begin{array}{c}\text { Down } \\
\text { Consistency, } \\
\text { cP }\end{array}$ \\
\hline DWPF Ranges & $20-35$ & 2.5 to 15 & 2.5 to 15 & 10 to 40 & 10 to 40 \\
\hline GF34 Hi Fe-Hi Mn & 37.9 & 9.1 & 12.2 & 33.1 & 26.4 \\
\hline GF35 Lo Fe-Hi Mn & 37.6 & -0.1 & 1.5 & 20.2 & 11.7 \\
\hline GF36 Hi Fe-Lo Mn & 35.3 & 12.3 & 15.9 & 34.8 & 24.7 \\
\hline GF37 Lo Fe-Lo Mn* & 29.7 & 8.9 & 11.1 & 24.6 & 18.0 \\
\hline GF40 & 36.9 & 0.15 & 0.12 & 14.2 & 5.02 \\
\hline GF41 & 41.0 & 0.34 & 1.53 & 47.1 & 18.0 \\
\hline
\end{tabular}

The SME products from runs GF35-36 were further concentrated by evaporation to determine the extent of concentration that could be achieved with each SME product (for example GF $35-48 \%$ means the total solids target was $48 \%$, Insoluble solids was $39.7 \%$ ). Insufficient material was remaining from run GF37, so no concentration of this sample was completed. The data is summarized in Table 3-33.

Table 3-33. Post Concentration SME Product solids content, wt \% total solids basis

\begin{tabular}{|llll|}
\hline Sample \# & $\begin{array}{l}\text { Insoluble } \\
\text { Solids }\end{array}$ & Sample \# & $\begin{array}{l}\text { Insoluble } \\
\text { Solids }\end{array}$ \\
\hline GF35-48\% & $39.7 \%$ & GF36-48\% & $37.4 \%$ \\
\hline GF35-51\% & $43.1 \%$ & GF36-51\% & $39.0 \%$ \\
\hline GF35-54\% & $46.6 \%$ & GF36-54\% & $43.2 \%$ \\
\hline GF35-57\% & $49.4 \%$ & GF36-57\% & $41.6 \%$ \\
\hline GF35-60\% & $50.6 \%$ & & \\
\cline { 1 - 2 } & & &
\end{tabular}


The rheology of these concentrated SME products was analyzed to determine the rheology and the data is summarized in Figure 3-20.

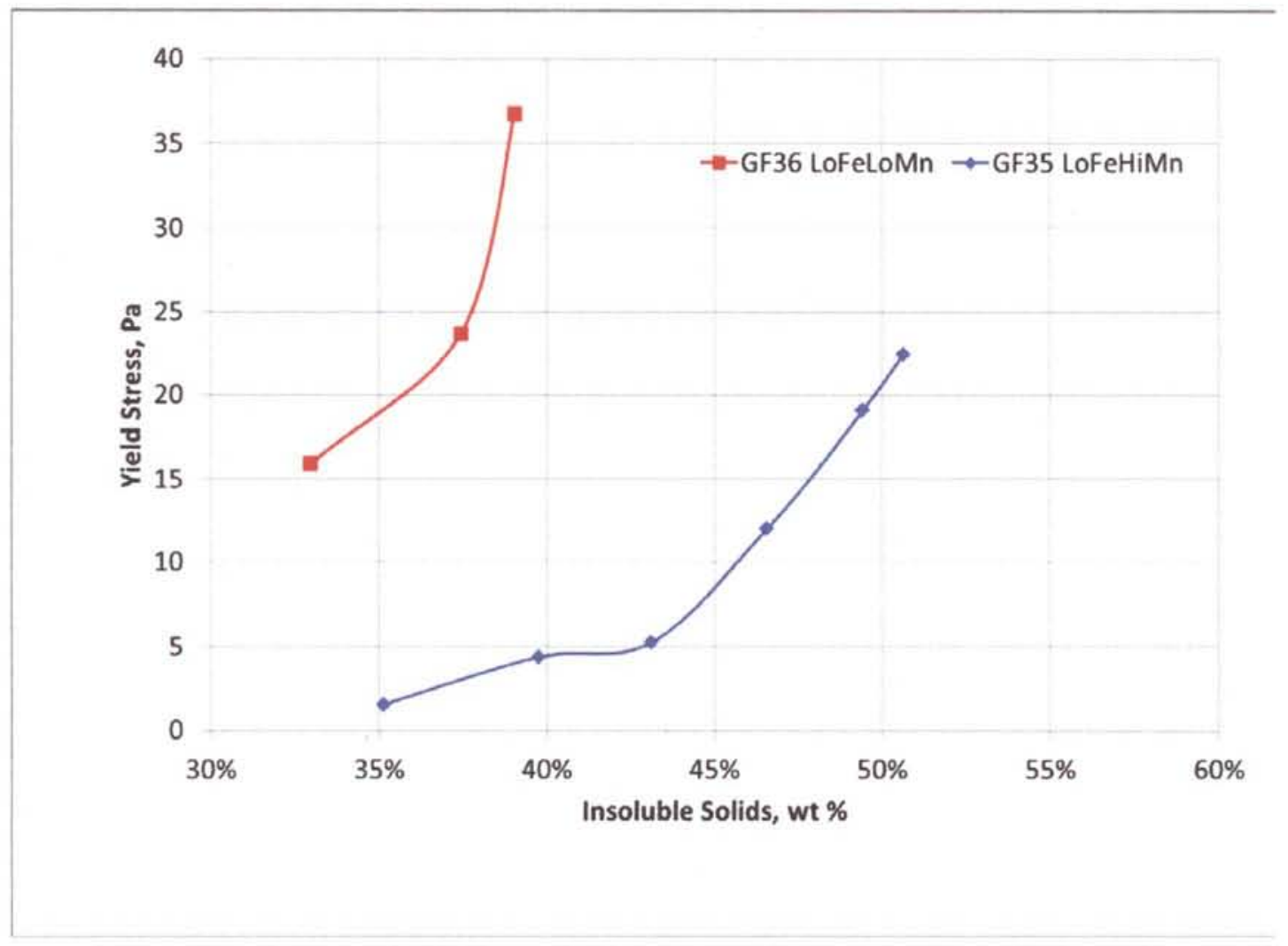

Figure 3-20.SME Product Rheology of Concentrated Subsamples

Lab-scale concentration of the two SME products to high wt\% solids was problematic. Several laboratory rig kettles broke during concentration. It was important to mix well and to not have solids buildup during evaporation. The solids buildup led to localized overheating where the solids built up and to subsequent glass breakage. The high agitation speeds needed to mitigate solids buildup also led to breakage of the glassware, especially when the total solids exceeded $60 \mathrm{wt} \%$. However, in most sludge tanks it is expected that the maximum concentration of SRAT and SME product will be significantly higher with the Glycolic-Nitric Flowsheet than with the Baseline Flowsheet.

\subsubsection{SRAT/SME REDOX}

SME products from GF34, GF35, GF36 and GF37 (SME products) were added to an alumina crucible, dried to peanut butter consistency, and vitrified in nepheline sealed crucibles. SRAT product samples from runs GF36b, GF36c, GF37b and GF38 were prepared for the redox measurement by taking the SRAT product and adding frit 418 to produce a waste loading of $36 \%$. The resulting slurry was placed in a crucible, dried to peanut butter consistency and vitrified like the SME product samples from runs GF34, GF35, GF36 and GF37. 
The REDOX prediction equation used in this study with an added term for glycolate is:

$\mathrm{Fe}^{2+} / \Sigma \mathrm{Fe}=0.2358+0.1999 *(2[\mathrm{~F}]+4[\mathrm{C}]+6[\mathrm{G}]+4[\mathrm{O}]-5[\mathrm{~N}]-5[\mathrm{Mn}]) * 45 / \mathrm{T}$

Where

$[\mathrm{F}]=$ formate $(\mathrm{mol} / \mathrm{kg}$ feed $)$

$[\mathrm{C}]=\operatorname{coal}($ carbon $)(\mathrm{mol} / \mathrm{kg}$ feed $)$

$[\mathrm{O}]=$ oxalate (soluble and insoluble) $(\mathrm{mol} / \mathrm{kg}$ feed $)$

$[\mathrm{G}]=$ glycolate $(\mathrm{mol} / \mathrm{kg}$ feed $)$

$[\mathrm{N}]=$ nitrate + nitrite $(\mathrm{mol} / \mathrm{kg}$ feed $)$

$[\mathrm{Mn}]=$ manganese $(\mathrm{mol} / \mathrm{kg}$ feed $)$

Values less than zero or greater than one can be calculated with the REDOX equation, because it is a linear regression equation fit to experimental data. Values outside the range of zero to one, however, are physically impossible. A number less than zero can be interpreted as fully oxidized and likewise a number greater than one as fully reduced.

Table 3-34 below shows the appropriate SME product data with the corresponding predicted REDOX values as well as the REDOX as measured. Note that the REDOX equation generally underpredicts the measured REDOX.

Table 3-34. SME product data for REDOX calculations, $\mathrm{Fe}^{2+} / \mathrm{Le}$

\begin{tabular}{|lccc|}
\hline Run & Sludge & Predicted Redox* & Measured Redox \\
\hline GF34 & HiFeHiMn & 0.064 & 0.319 \\
\hline GF34b & HiFeHiMn & 0.082 & 0.400 \\
\hline GF34c & HiFeHiMn & 0.145 & 0.507 \\
\hline GF35 & SB7A & 0.419 & 0.506 \\
\hline GF36 & HiFeLoMn & 0.031 & 0.280 \\
\hline GF36b & HiFeLoMn & 0.178 & 0.286 \\
\hline GF36c & HiFeLoMn & 0.207 & 0.226 \\
\hline GF37 & LoFeLoMn & 0.123 & 0.463 \\
\hline GF37b & LoFeLoMn & 0.256 & 0.559 \\
\hline GF38 & LoFeLoMn & 0.524 & 0.665 \\
\hline GF40 & $2.0 \mathrm{MNa}$ & 0.298 & 0.329 \\
\hline GF41 & $2.5 \mathrm{M} \mathrm{Na}$ & 0.355 & 0.510 \\
\hline Predicted REDOX was calculated using measured sample results.
\end{tabular}

Both LoFe (HiAl) runs had significantly higher measured REDOX than the HiFe runs. The melter feed iron concentration may impact the percentage of iron that is reduced to $\mathrm{Fe}^{2+}$. This may not be as evident in sludge batch processing, as the iron concentration doesn't change as much as the matrix sludges. This may be an important clue in developing a REDOX equation for the glycolicnitric acid flowsheet.

It is possible that the anion analyses used to predict REDOX were inaccurate. As a result, the GF34, GF35, GF36, and GF37 SME products were reanalyzed and the original results (GF3x\#1) and reanalysis (GF3x\#2) are summarized in Table 3-35. 
Table 3-35. Repeat Analysis of SME anion data for REDOX calculations, $\mathrm{Fe}^{2+} / \Sigma \mathrm{Fe}$

\begin{tabular}{|llclcc|}
\hline Result & $\begin{array}{l}\text { Nitrate, } \\
\mathbf{m g} / \mathbf{k g}\end{array}$ & $\begin{array}{l}\text { Formate, } \\
\mathbf{m g} / \mathbf{k g}\end{array}$ & $\begin{array}{l}\text { Glycolate, } \\
\mathbf{m g} / \mathbf{k g}\end{array}$ & $\begin{array}{l}\text { Oxalate, } \\
\mathbf{m g} / \mathbf{k g}\end{array}$ & $\begin{array}{l}\text { SME } \\
\text { Predicted } \\
\text { Redox }\end{array}$ \\
\hline GF34\#1 & 43,650 & 1,405 & 37,250 & 1,670 & 0.064 \\
\hline GF34\#2 & 44,000 & 1,420 & 38,200 & 5,220 & 0.106 \\
\hline GF35\#1 & 34,750 & 2,330 & 30,750 & 4,370 & 0.119 \\
\hline GF35\#2 & 33,300 & 2,710 & 29,850 & 4,525 & 0.133 \\
\hline GF36\#1 & 43,650 & 1,720 & 28,200 & 4,150 & 0.031 \\
\hline GF36\#2 & 46,150 & 1,785 & 31,450 & 5,700 & 0.057 \\
\hline GF37\#1 & 38,450 & 1,855 & 30,700 & 2,830 & 0.147 \\
\hline GF37\#2 & 39,850 & 1,680 & 29,850 & 4,540 & 0.125 \\
\hline
\end{tabular}

The reanalysis of the anions did not appreciably change the concentrations or the REDOX predications. A comparison of the original and reanalyzed results is summarized in Table 3-36. Note that oxalate concentrations of three of the four samples changed significantly.

Table 3-36. Change in Anion Concentration due to Reanalysis of SME Product Samples

\begin{tabular}{|lcccc|}
\hline Anion & GF34 & GF35 & GF36 & GF37 \\
\hline Nitrate & $0.8 \%$ & $-4.2 \%$ & $5.7 \%$ & $3.6 \%$ \\
\hline Formate & $1.1 \%$ & $16.3 \%$ & $3.8 \%$ & $-9.4 \%$ \\
\hline Glycolate & $2.6 \%$ & $-2.9 \%$ & $11.5 \%$ & $-2.8 \%$ \\
\hline Oxalate & $212.6 \%$ & $3.5 \%$ & $37.3 \%$ & $60.4 \%$ \\
\hline
\end{tabular}

A $10 \mathrm{ppm}$ spike of nitrate, formate, glycolate, and oxalate was added to each diluted SME product subsample and analyzed by PSAL using the glycolate IC method ${ }^{16}$. The spiked samples were analyzed and the added spike was calculated (Table 3-37). Note that the calculated spike concentration of oxalate increased from 8.17 to 10.85 during this testing. It is likely that recovery of the oxalate from the IC column was not equal to the oxalate added, possibly because the column is "dirty".

Table 3-37. Spiked Recovery of SME Product Samples, mg/kg slurry

\begin{tabular}{|lcccc|}
\hline Anion & GF34 & GF35 & GF36 & GF37 \\
\hline Nitrate & 9.81 & 9.89 & 9.82 & 10.0 \\
\hline Formate & 10.35 & 10.11 & 10.55 & 10.7 \\
\hline Glycolate & 10.05 & 10.05 & 10.2 & 10.25 \\
\hline Oxalate & 8.17 & 9.34 & 9.64 & 10.85 \\
\hline
\end{tabular}

The SME products were also analyzed for TOC. This was compared to calculated TOC concentration based on the analyzed glycolate, formate, and oxalate concentrations, converted to TOC. The data are summarized in Table 3-38. The good agreement between the measured and predicted TOC suggests that the analyses of the oxalate, formate, and glycolate concentrations are accurate enough to predict REDOX. No term was added to the TOC for the antifoam contribution 
since it was not measured. Based on the $800 \mathrm{ppm}$ antifoam addition and the fact that the antifoam is about half carbon, the predicted TOC could be as much as $400 \mathrm{ppm}$ higher if an antifoam term was added.

Table 3-38. TOC Analysis and Calculation of SME Product Samples, mg/kg slurry

\begin{tabular}{|lcccc|}
\hline Anion & GF36b & GF36c & GF37b & GF38 \\
\hline Measured TOC & 19,700 & 28,600 & 24,500 & $26,200^{*}$ \\
\hline Predicted TOC & 21,300 & 23,900 & 24,100 & 26,000 \\
\hline
\end{tabular}

* The analytical result was corrected for added frit in preparing melter feed for REDOX testing.

Based on the anion results and using these to predict REDOX, it is evident that either the anion results are inaccurate or that the REDOX prediction equation is inadequate for the glycolic-nitric flowsheet REDOX prediction. In runs using the two HiFe slurries (GF34 and GF36), the predicted REDOX, although still lower than the measured REDOX, better agreed with the measured REDOX. One question it raises is whether additional terms are needed in this equation to adequately predict REDOX. It is also evident that additional work is needed to improve the current IC method, especially concerning oxalate and glycolate analyses. For instance, the measured glycolate was approximately twice that predicted (and much higher than is possible from the known addition of glycolic acid).

\subsubsection{SRAT pH profile}

Time dependent SRAT/SME pH data were collected for all runs. The graph below, Figure 3-21, shows the $\mathrm{pH}$ trends of all runs. The $\mathrm{pH}$ stays very stable throughout the SRAT and SME cycles, unlike the Baseline flowsheet where the SME product $\mathrm{pH}$ may be as high as 10 or 11 . In addition, the $\mathrm{pH}$ of the duplicate GF36 runs is included in Figure 3-22 to demonstrate the same pH profile was achieved in all three runs. 


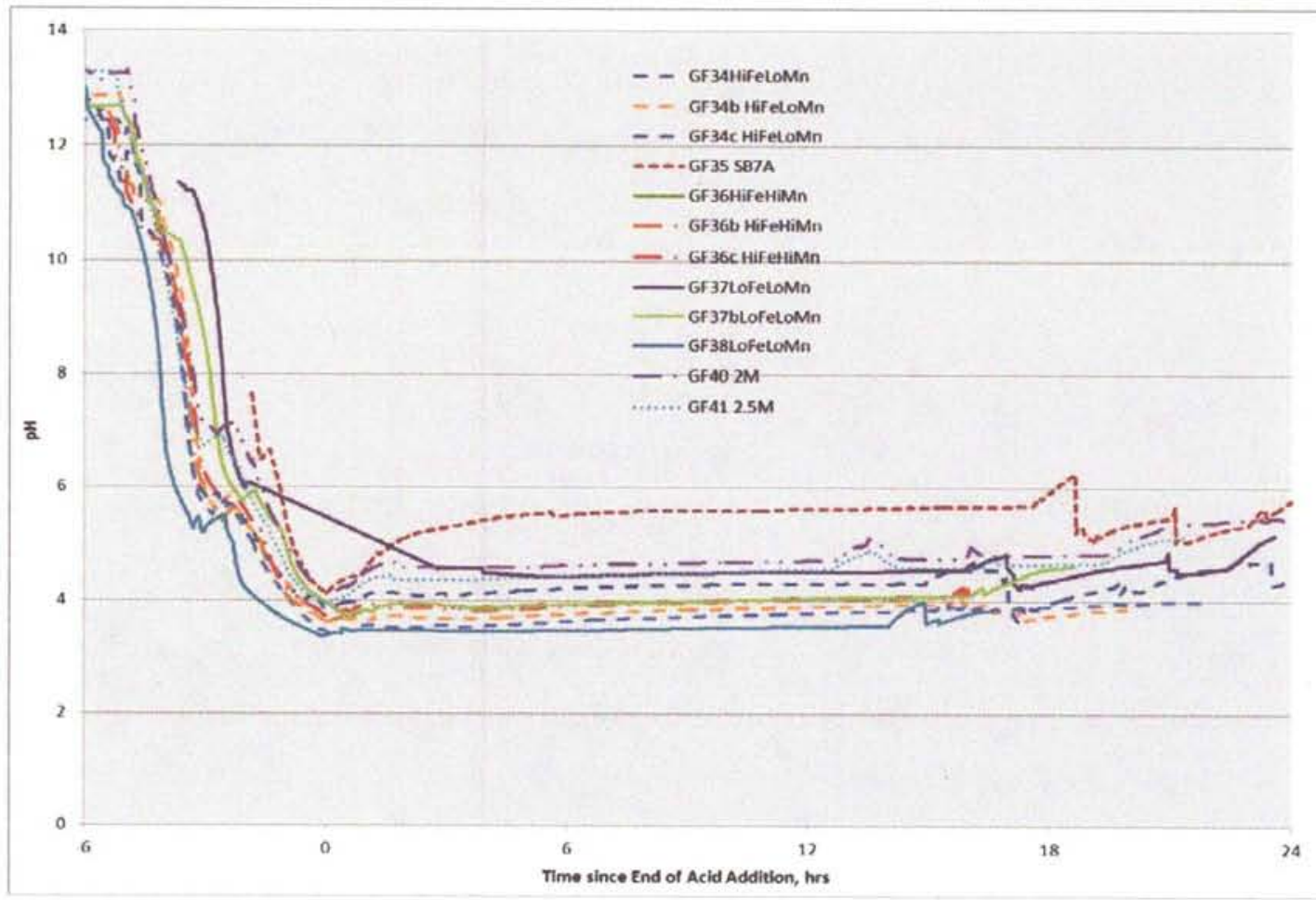

Figure 3-21. pH trends for SRAT and SME Cycles

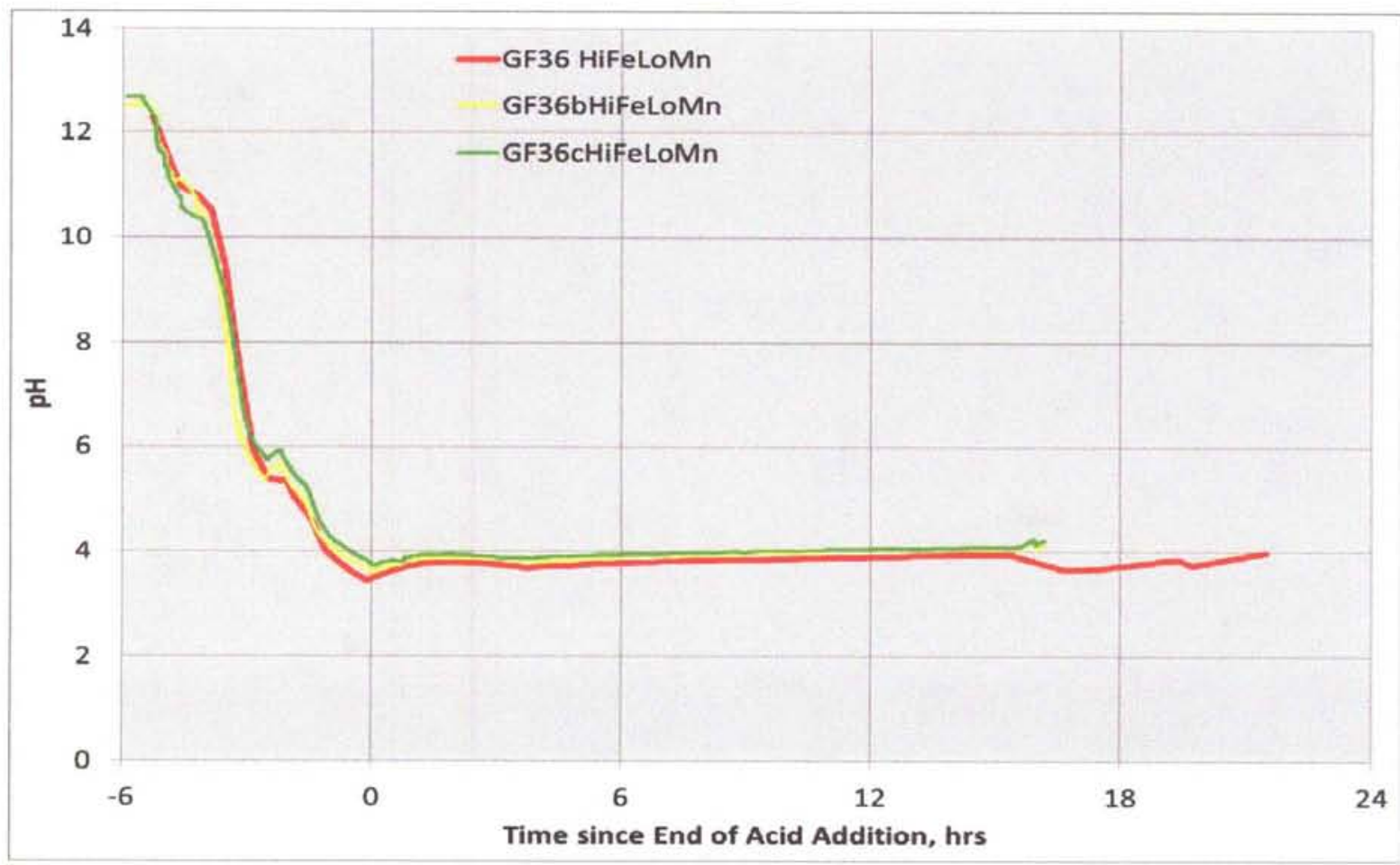

Figure 3-22. pH trends for Duplicate GF36 SRAT Cycles 


\subsubsection{Foaming}

Foaminess was not a concern in these runs. The antifoam strategy, $200 \mathrm{ppm}$ before acid addition, $100 \mathrm{ppm}$ after nitric acid addition, $500 \mathrm{ppm}$ at the completion of acid addition and $100 \mathrm{ppm}$ before the start of the SME cycle was more than enough antifoam to control foaming throughout the matrix testing. This is particularly significant since six different simulants containing very different insoluble solids compositions were used in the testing.

Subsequent testing has used a revised antifoam strategy. Since the antifoam is most stable at $\mathrm{pH} 7$, and has good stability from $\mathrm{pH} 4$ to 10 , antifoam was not added until the $\mathrm{pH}$ dropped below 10 during acid addition. In these tests this was approximately the completion of nitric acid addition. Since DWPF does not have a pH probe in the SRAT, the GC offgas analysis may be useful in determining this point as no foaming is expected until significant offgas generation ensues with the evolution of $\mathrm{CO}_{2}$ and $\mathrm{N}_{2} \mathrm{O}$. However, the lag time between generation and $\mathrm{GC}$ analysis and the lack of $\mathrm{CO}_{2}$ and $\mathrm{N}_{2} \mathrm{O}$ my make this impractical. In these later runs, $100 \mathrm{mg} / \mathrm{kg}$ at pH $10,100 \mathrm{mg} / \mathrm{kg}$ prior to SRAT boiling and $100 \mathrm{mg} / \mathrm{kg}$ every 12 hours during SRAT processing was sufficient to control foam, even in the underwashed $1.6 \mathrm{M}$ and $1.9 \mathrm{M}$ Na sludges.

The FTIR was used to monitor the offgas during the GF40 and GF41 runs. HDMSO was detected throughout the SRAT and SME cycle. The HDMSO is a degradation product of the added antifoam and results in decreasing antifoam performance over time. Integration of the HDMSO over the SRAT and SME cycle was used to estimate the antifoam degradation. The mass of HDMSO in Run GF41 was $110 \%$ of that predicted by the known antifoam added. The HDMSO peaks correlate well with the antifoam additions. The HDMSO concentration profile is included in Figure 3-23.

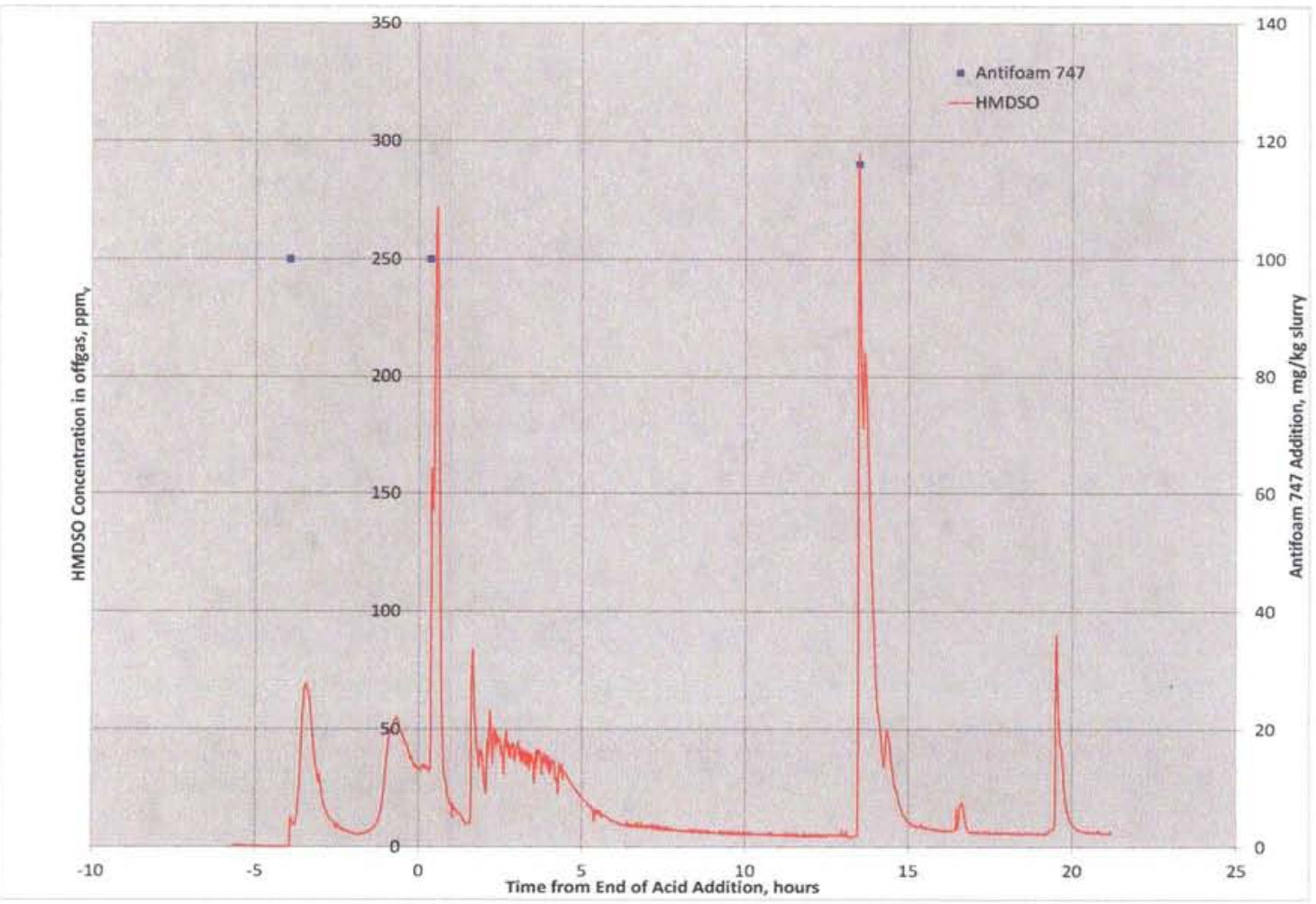

Figure 3-23. HDMSO Concentration during GF41 SRAT and SME cycle 
Although this antifoam strategy was successful in processing simulants, the offgas and boiling fluxes are much lower in simulant experiments than DWPF. Plus, the simulants are generally rheologically less viscous than real waste. As a result, the antifoam strategy should be demonstrated in the largest scale testing and with real waste if feasible.

\subsubsection{Heat Transfer Calculations}

The SRAT/SME apparatus used had two immersed heating rods to heat the slurry instead of the mantle that has been used in the past. Each heating rod has a four-inch heated section and has a maximum heat input of 750 watts. The temperature of the rod was limited to approximately $130^{\circ} \mathrm{C}$ by the temperature controller to prevent overheating the rod in the case of rod fouling. The use of the heating rods has several distinct advantages, including measurement of heating rod temperatures and heat input, allowing calculation of heat transfer coefficients. In addition, the heating rods more closely resemble the steam coils and can "foul" just like a heating coil.

The heat transfer coefficient of the rods was calculated as a function of time throughout the runs. The data are summarized in Figure 3-24. Note that the heat transfer coefficient was very consistent throughout the SRAT cycles. In run GF37 (LoFeLoMn), the heat transfer coefficient dropped from about 0.14 to 0.07 . This run was very difficult to concentrate and the SME cycle concentration after the second frit addition was not finished due to breakage of the glassware. Calculation of the heat transfer coefficient is useful in predicting fouling. The power input to the rods is summarized in Figure 3-25.

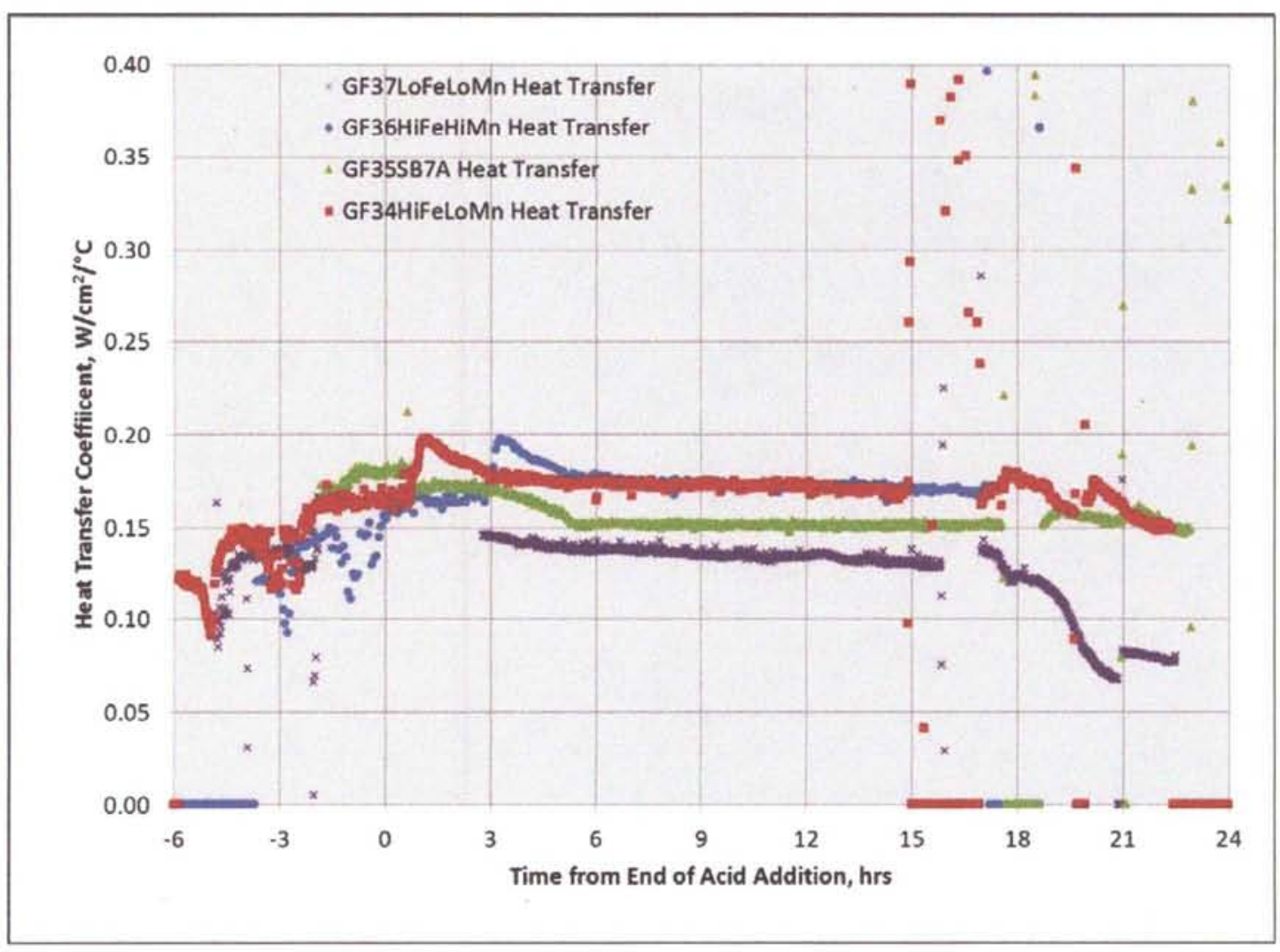

Figure 3-24.Heat Transfer Coefficient, W/ $/ \mathrm{cm}^{2} /{ }^{\circ} \mathrm{C}$ 


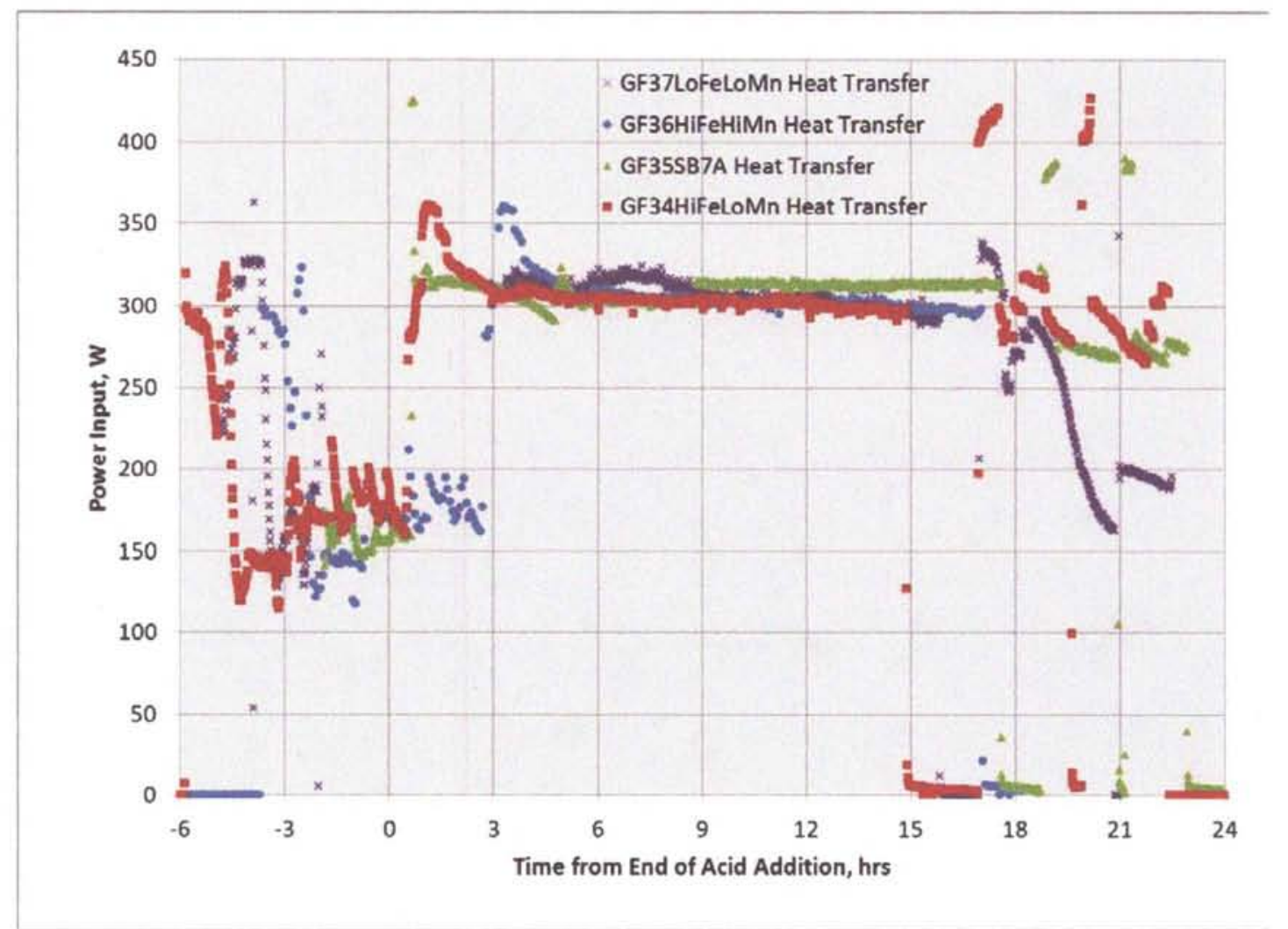

Figure 3-25. Power Input, W

Fouling was experienced in the problematic run GF37 (LoFeLoMn), and the fouled rod was photographed following the SME cycle (Figure 3-26). Note that neither the other rod nor the agitator was fouled. 


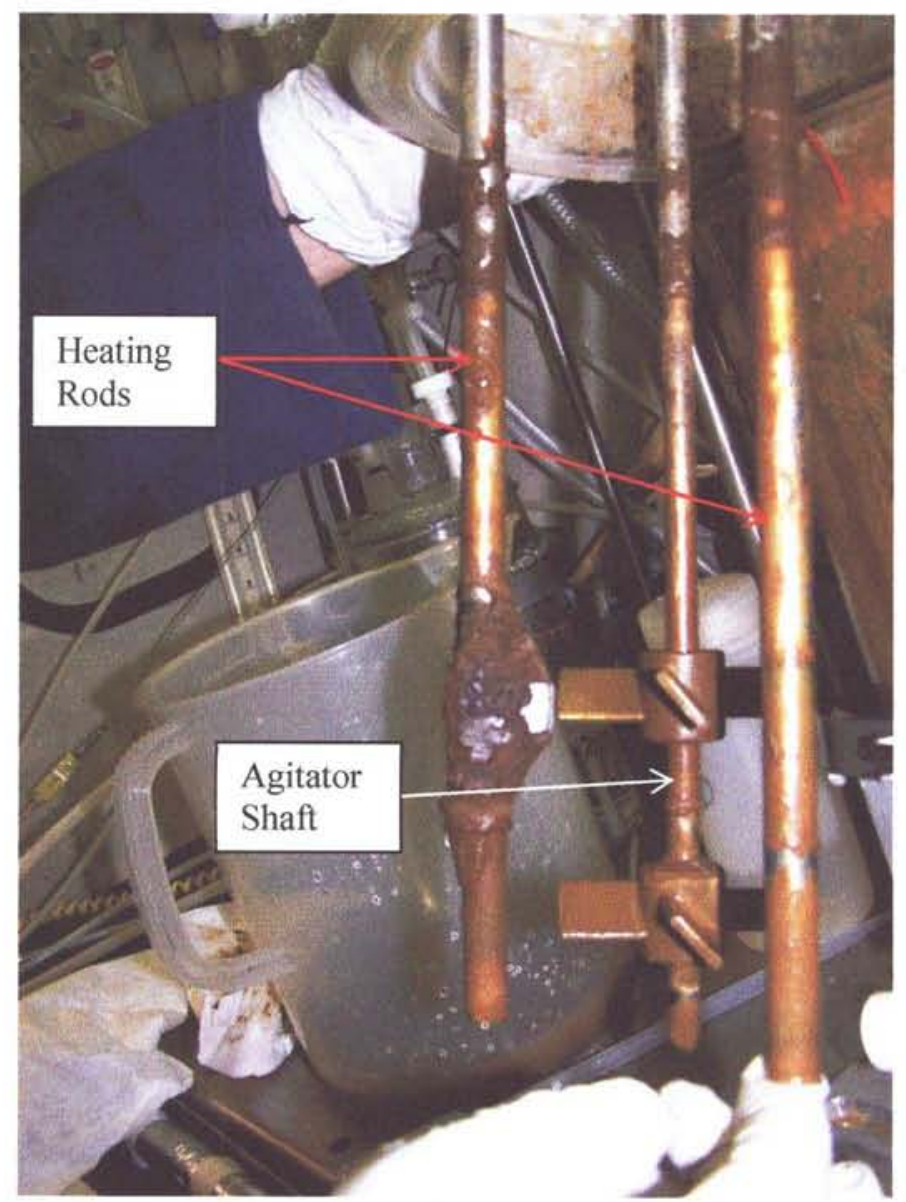

Figure 3-26. Photograph of Fouled Heating Rod after Run GF37 SME

\subsubsection{Comparison of Identical Runs}

After completing the first four runs (GF34-GF37) and recovering relatively little mercury in the MWWT, four additional runs were completed. Run GF36 was duplicated in both the new (GF36b) and older (GF36c) kettle configurations to ensure that the equipment change was not responsible for the poor mercury recovery. In virtually every measure, these two runs were as close to identical as was feasible. The collection of mercury was also very similar in the two duplicate runs. However, the supernate was different in GF36 compared to GF36b and GF36c. For example, the iron and aluminum were higher in the GF36b and $36 \mathrm{c}$ and the supernate was also a darker color.

In order to easily compare the identical runs, it is important to put the analytical data on the same basis. Each rig is built separately and can have varying levels of leak tightness. In runs with a tighter seal, less water is lost through the agitator seal, joints and connections. As a result, the solids and ICP-AES supernate results were corrected to the same basis, the target total solid concentration for each run. For Run GF36, the target total solids concentration was $30.3 \mathrm{wt} \%$. Total solids and anion concentrations in GF36b and GF36c were corrected as if these runs had also finished with a SRAT product at $27.9 \mathrm{wt} \%$ solids. The corrected results are summarized in Table 3-39. 
Table 3-39. GF36 Corrected Solids Concentrations

\begin{tabular}{|c|c|c|c|c|c|c|}
\hline & \multicolumn{3}{|c|}{ Actual } & \multicolumn{3}{|c|}{ Corrected } \\
\hline Run & GF36 & GF36b & GF36c & GF36 & GF36b & GF36c \\
\hline Total Solids, wt $\%$ & 30.32 & 27.58 & 27.71 & 27.90 & 27.90 & 27.90 \\
\hline Insoluble Solids, wt\% & 17.03 & 13.70 & 13.27 & 15.68 & 13.86 & 13.37 \\
\hline Soluble Solids, wt $\%$ & 13.28 & 13.88 & 14.43 & 12.22 & 14.04 & 14.53 \\
\hline Calcined Solids, wt $\%$ & 16.68 & 15.04 & 15.15 & 15.35 & 15.21 & 15.25 \\
\hline Al, mg/L Supernate & 411 & 2,280 & 2,250 & 447 & 2,250 & 2,240 \\
\hline Ba, mg/L Supernate & 1.65 & 3.28 & 3.32 & 1.79 & 3.24 & 3.30 \\
\hline Ca, mg/L Supernate & 2,390 & 3,350 & 3,490 & 2,600 & 3,310 & 3,460 \\
\hline Cr, mg/L Supernate & 32.0 & 54.9 & 53.7 & 34.8 & 54.2 & 53.4 \\
\hline $\mathrm{Cu}, \mathrm{mg} / \mathrm{L}$ Supernate & 11.9 & 25.9 & 24.6 & 12.9 & 25.6 & 24.4 \\
\hline Fe, mg/L Supernate & 1,040 & 2,810 & 3,290 & 1,130 & 2,780 & 3,270 \\
\hline K, mg/L Supernate & 272 & 16.4 & 5.23 & 296 & 16.2 & 5.19 \\
\hline Mg, mg/L Supernate & 4,830 & 4,470 & 4,050 & 5,240 & 4,410 & 4,020 \\
\hline Mn, mg/L Supernate & 1,330 & 1,280 & 1,150 & 1,450 & 1,270 & 1,150 \\
\hline $\mathrm{Na}, \mathrm{mg} / \mathrm{L}$ Supernate & 26,500 & 28,100 & 25,900 & 28,900 & 27,800 & 25,700 \\
\hline Ni, mg/L Supernate & 2,940 & 3,160 & 2,850 & 3,190 & 3,120 & 2,830 \\
\hline $\mathrm{Pb}, \mathrm{mg} / \mathrm{L}$ Supernate & 0.610 & 2.29 & 2.01 & 0.663 & 2.26 & 1.20 \\
\hline Pd, mg/L Supernate & 0.160 & 0.180 & 0.130 & 0.174 & 0.178 & 0.129 \\
\hline Rh, mg/L Supernate & 10.7 & 18.4 & 15.0 & 11.6 & 18.2 & 14.9 \\
\hline Ru, mg/L Supernate & 181 & 229 & 206 & 197 & 226 & 205 \\
\hline S, mg/L Supernate & 572 & 453 & 482 & 622 & 448 & 479 \\
\hline $\mathrm{Si}, \mathrm{mg} / \mathrm{L}$ Supernate & 17.4 & 132 & 68.8 & 18.9 & 131 & 68.3 \\
\hline Zr, mg/L Supernate & 14.5 & 60.9 & 62.0 & 15.8 & 60.2 & 61.6 \\
\hline
\end{tabular}

Note that the corrected calcined solids analysis is very similar in all three runs. However, the ratio of soluble solids to total solids is much lower for GF36 than for GF36b or GF36c. In addition, both $\mathrm{Fe}$ and $\mathrm{Al}$ in supernate are much higher in GF36b and GF36c than in GF36. The solids identified in $\mathrm{XRD}$ were $\mathrm{Al}$ and $\mathrm{Fe}$ species. This is consistent with crystal formation post processing in GF36 but not GF36b or GF36c. It also was noted visually that the supernate for GF36 was much clearer than GF36b or GF36c.

Significant differences in these runs are summarized in Table 3-40. Note that the data is reported on slurry basis. 
Table 3-40. Analyses of Interest of Duplicate Runs, Anions and Solids Concentrations Corrected

\begin{tabular}{|c|c|c|c|c|c|c|}
\hline Analyte & GF36 & GF36b & GF36c & GF37 & GF37b & GF38 \\
\hline Formate, $\mathrm{mg} / \mathrm{kg}$ slurry & $<100$ & $<100$ & $<100$ & $<100$ & $<100$ & $<100$ \\
\hline Chloride, mg/kg slurry & 622 & 591 & 602 & 821 & 590 & 583 \\
\hline Nitrite, $\mathrm{mg} / \mathrm{kg}$ slurry & $<100$ & $<100$ & $<100$ & $<100$ & $<100$ & $<100$ \\
\hline Nitrate, $\mathrm{mg} / \mathrm{kg}$ slurry & 57,500 & 56,700 & 56,300 & 56,500 & 52,500 & 56,900 \\
\hline Sulfate, $\mathrm{mg} / \mathrm{kg}$ slurry & 1,210 & 1,280 & 1,240 & 1,500 & 1,445 & 1,420 \\
\hline Oxalate, $\mathrm{mg} / \mathrm{kg}$ slurry & 3,950 & 3,190 & 3,210 & 2,755 & 2,420 & 2,655 \\
\hline Glycolate, $\mathrm{mg} / \mathrm{kg}$ slurry & 37,300 & 51,300 & 53,100 & 42,200 & 55,500 & 77,900 \\
\hline Formate, $\mathrm{mg} / \mathrm{L}$ supernate & $<100$ & $<100$ & $<100$ & $<100$ & $<100$ & $<100$ \\
\hline Chloride, $\mathrm{mg} / \mathrm{L}$ supernate & 858 & 736 & 783 & 913 & 772 & 746 \\
\hline Nitrite, $\mathrm{mg} / \mathrm{L}$ supernate & $<100$ & $<100$ & $<100$ & $<100$ & $<100$ & $<100$ \\
\hline Nitrate, $\mathrm{mg} / \mathrm{L}$ supernate & 86,300 & 74,000 & 74,300 & 82,100 & 70,900 & 77,300 \\
\hline Sulfate, $\mathrm{mg} / \mathrm{L}$ supernate & 2,170 & 1,530 & 1,610 & 2,740 & 1,850 & 1,790 \\
\hline Oxalate, $\mathrm{mg} / \mathrm{L}$ supernate & 3,250 & 4,060 & 4,240 & 3,860 & 3,030 & 3,610 \\
\hline Glycolate, $\mathrm{mg} / \mathrm{L}$ supernate & 46,700 & 64,500 & 70,700 & 61,300 & 72,500 & 98,100 \\
\hline $\mathrm{Al}, \mathrm{wt} \% \mathrm{CS}$ & 9.1 & 9.2 & 9.1 & 23.7 & 23.5 & 23.9 \\
\hline Ba & 0.095 & 0.094 & 0.092 & 0.063 & 0.064 & 0.063 \\
\hline $\mathrm{Ca}$ & 2.120 & 1.95 & 1.93 & 1.67 & 1.65 & 1.69 \\
\hline $\mathrm{Cr}$ & 0.273 & 0.269 & 0.269 & 0.223 & 0.224 & 0.220 \\
\hline $\mathrm{Cu}$ & 0.054 & 0.043 & 0.040 & 0.051 & 0.040 & 0.041 \\
\hline $\mathbf{F e}$ & 32.0 & 32.9 & 32.9 & 12.5 & 12.3 & 12.3 \\
\hline K & 0.061 & 0.077 & 0.083 & 0.071 & 0.079 & 0.086 \\
\hline Mg & 2.57 & 2.77 & 2.76 & 2.36 & 2.40 & 2.43 \\
\hline Mn & 0.705 & 0.640 & 0.631 & 0.666 & 0.601 & 0.595 \\
\hline $\mathrm{Na}$ & 13.5 & 13.4 & 13.2 & 15.3 & 14.1 & 14.5 \\
\hline $\mathrm{Ni}$ & 2.69 & 2.73 & 2.73 & 2.37 & 2.35 & 2.37 \\
\hline $\mathrm{Pb}$ & 0.056 & 0.049 & 0.041 & 0.058 & 0.050 & 0.039 \\
\hline Pd & $<0.100$ & $<0.010$ & $<0.010$ & $<0.100$ & $<0.010$ & $<0.010$ \\
\hline $\mathbf{R h}$ & 0.033 & $<0.100$ & $<0.100$ & 0.047 & $<0.100$ & $<0.100$ \\
\hline Ru & 0.032 & $<0.100$ & $<0.100$ & 0.030 & $<0.100$ & $<0.100$ \\
\hline S & 0.276 & 0.264 & 0.269 & 0.294 & 0.283 & 0.260 \\
\hline $\mathrm{Si}$ & 1.95 & 1.82 & 1.76 & 1.3 & 1.42 & 1.39 \\
\hline Sn & 0.107 & 0.102 & 0.102 & 0.089 & 0.094 & 0.093 \\
\hline $\mathrm{Zn}$ & 0.072 & 0.071 & 0.070 & 0.061 & 0.062 & 0.062 \\
\hline $\mathrm{Zr}$ & 0.117 & 0.110 & 0.110 & 0.045 & 0.040 & 0.044 \\
\hline $\mathrm{Al}, \mathrm{mg} / \mathrm{L}$ & 411 & 2,280 & 2,250 & 554 & 2,200 & 4,040 \\
\hline $\mathrm{Ba}$ & 1.65 & 3.28 & 3.32 & 1.26 & 2.69 & 3.37 \\
\hline $\mathrm{Ca}$ & 2,390 & 3,350 & 3,490 & 2,150 & 3,040 & 2,87 \\
\hline $\mathrm{Cr}$ & 32.04 & 54.85 & 53.7 & 86.0 & 103 & 198 \\
\hline $\mathrm{Cu}$ & 11.9 & 25.9 & 24.6 & 15.1 & 24.7 & 38.5 \\
\hline $\mathrm{Fe}$ & 1,040 & 2,810 & 3,290 & 328 & 1,490 & 3,560 \\
\hline K & 272 & 16.4 & 5.23 & 290 & 265 & 247 \\
\hline $\mathrm{Mg}$ & 4,825 & 4,470 & 4,050 & 4,410 & 4,090 & 4,180 \\
\hline Mn & 1,330 & 1,280 & 1,150 & 1,300 & 1,280 & 922 \\
\hline $\mathrm{Na}$ & 26,500 & 28,100 & 25,900 & 30,400 & 29,800 & 28,500 \\
\hline $\mathrm{Ni}$ & 2,940 & 3,160 & 2,850 & 3,170 & 3,180 & 3,970 \\
\hline $\mathrm{Pb}$ & 0.61 & 2.29 & 2.01 & 2.31 & 4.15 & 18.9 \\
\hline Pd & 0.16 & 0.18 & 0.13 & 0.18 & $<0.100$ & $<0.100$ \\
\hline $\mathbf{R h}$ & 10.7 & 18.4 & 15.0 & 12.0 & 36.1 & 78.3 \\
\hline
\end{tabular}


SRNL-STI-2012-00018

Revision 1

\begin{tabular}{|ccccccc|}
\hline Analyte & GF36 & GF36b & GF36c & GF37 & GF37b & GF38 \\
\hline Ru & 181 & 229 & 206 & 289 & 330 & 453 \\
\hline $\mathrm{S}$ & 572 & 453 & 482 & 672 & 599 & 513 \\
\hline $\mathrm{Si}$ & 17.4 & 132 & 68.8 & 67.4 & 121 & 103 \\
\hline $\mathrm{Sr}$ & 3.06 & $\mathrm{NM}$ & $\mathrm{NM}$ & 2.99 & 41.6 & 77.3 \\
\hline $\mathrm{Zr}$ & 14.5 & 60.9 & 62.0 & 17.7 & 38.3 & 50.7 \\
\hline
\end{tabular}

\subsubsection{Reanalysis of Anions}

Since the measured glass REDOX was much more reducing than predicted, the anions were reanalyzed by both Analytical Development (AD) and PSAL (Table 2-1). The accurate measurement of four anions, nitrate, glycolate, oxalate, and formate is necessary to predict redox. It is apparent from the PSAL reanalysis results that nitrate ion concentration is a very robust analysis, but that the oxalate and glycolate concentrations vary during reanalysis. In fact, a number of unreported glycolate results were so high that they greatly exceeded the maximum concentration of glycolate possible based on the glycolic acid added.

Table 3-41. Anion and TOC Analyses for Runs GF36b, 36c, 37b and 38, mg/kg

\begin{tabular}{|llccccccc|}
\hline Sample ID & $\begin{array}{l}\mathrm{Lab} \\
\text { ID }\end{array}$ & $\mathrm{Cl}$ & $\mathrm{NO}_{3}$ & $\mathrm{SO}_{4}$ & $\mathrm{C}_{2} \mathrm{O}_{4}$ & $\mathrm{C}_{2} \mathrm{H}_{3} \mathrm{O}_{3}$ & $\begin{array}{r}\text { TOC } \\
\text { Calc }\end{array}$ & $\begin{array}{c}\text { Baseline } \\
\text { TOC }\end{array}$ \\
\hline 12-GF36b-6160A & PSAL & 736 & 74,000 & $\mathbf{1 , 5 3 0}$ & $\mathbf{4 , 0 6 0}$ & $\mathbf{6 4 , 5 0 0}$ & $\mathbf{2 1 , 8 0 0}$ & $\mathbf{1 9 , 7 0 0}$ \\
\hline 12-GF36b-6160A & PSAL & $\mathbf{7 1 7}$ & $\mathbf{7 2 , 5 0 0}$ & $\mathbf{1 , 5 5 0}$ & $\mathbf{4 , 1 3 0}$ & $\mathbf{6 1 , 7 0 0}$ & $\mathbf{2 0 , 9 0 0}$ & $\mathbf{1 9 , 7 0 0}$ \\
\hline 12-GF36b-6160C & AD & 545 & $\mathbf{5 7 , 1 0 0}$ & $\mathbf{1 , 0 3 0}$ & $\mathbf{2 , 4 4 0}$ & $\mathbf{3 3 , 9 0 0}$ & $\mathbf{1 1 , 5 0 0}$ & $\mathbf{1 9 , 7 0 0}$ \\
\hline 12-GF36c-6184A & PSAL & $\mathbf{7 8 3}$ & $\mathbf{7 4 , 3 0 0}$ & $\mathbf{1 , 6 1 0}$ & $\mathbf{4 , 2 4 0}$ & $\mathbf{7 0 , 7 0 0}$ & $\mathbf{2 3 , 8 0 0}$ & $\mathbf{2 8 , 6 0 0}$ \\
\hline 12-GF36c-6184A & PSAL & $\mathbf{7 7 4}$ & $\mathbf{7 4 , 5 0 0}$ & $\mathbf{1 , 6 5 0}$ & $\mathbf{3 , 6 5 0}$ & $\mathbf{7 2 , 0 0 0}$ & $\mathbf{2 4 , 1 0 0}$ & $\mathbf{2 8 , 6 0 0}$ \\
\hline 12-GF36c-6184C & AD & $\mathbf{5 8 9}$ & $\mathbf{5 6 , 0 0 0}$ & $\mathbf{1 , 0 1 0}$ & $\mathbf{1 , 9 4 0}$ & $\mathbf{3 4 , 4 0 0}$ & $\mathbf{1 1 , 5 0 0}$ & $\mathbf{2 8 , 6 0 0}$ \\
\hline 12-GF37b-6217A & PSAL & $\mathbf{7 7 2}$ & $\mathbf{7 0 , 9 0 0}$ & $\mathbf{1 , 8 5 0}$ & $\mathbf{3 , 0 3 0}$ & $\mathbf{7 2 , 5 0 0}$ & $\mathbf{2 4 , 1 0 0}$ & $\mathbf{2 4 , 5 0 0}$ \\
\hline 11-GF37b-6217C & AD & $\mathbf{5 5 9}$ & $\mathbf{5 1 , 7 0 0}$ & $\mathbf{1 , 2 5 0}$ & $\mathbf{1 , 3 4 0}$ & $\mathbf{3 5 , 9 0 0}$ & $\mathbf{1 1 , 9 0 0}$ & $\mathbf{2 4 , 5 0 0}$ \\
\hline 12-GF38-6249A & PSAL & $\mathbf{7 4 6}$ & $\mathbf{7 7 , 3 0 0}$ & $\mathbf{1 , 7 9 0}$ & $\mathbf{3 , 6 1 0}$ & $\mathbf{9 8 , 1 0 0}$ & $\mathbf{3 2 , 4 0 0}$ & $\mathbf{2 6 , 2 0 0}$ \\
\hline 12-GF38-6255C & AD & $\mathbf{3 2 1}$ & $\mathbf{5 8 , 1 0 0}$ & $\mathbf{1 , 1 6 0}$ & $\mathbf{2 , 3 9 0}$ & $\mathbf{5 4 , 5 0 0}$ & $\mathbf{1 8 , 1 0 0}$ & $\mathbf{2 6 , 2 0 0}$ \\
\hline
\end{tabular}

\subsubsection{Less Washed Sludge Processing}

In order to increase waste loading to $40 \%$ in future DWPF processing, less washing of sludges may be required ${ }^{22}$. In order to make a feed batch of $2 \mathrm{M} \mathrm{Na}$ in Tank 40 , a sludge batch as high as $2.5 \mathrm{M}$ $\mathrm{Na}$ may need to be prepared in Tank 51. Since the typical qualification of each batch includes a confirmation run in the SRNL Shielded Cells, successful lab-scale cells processing of $2.5 \mathrm{M} \mathrm{Na}$ sludge may be required. To support this testing, two sludge simulants were prepared, targeting 1.6 and $1.9 \mathrm{M} \mathrm{Na}$. These sludges, targeting the expected blend concentration in Tank 40 were used in a series of Baseline flowsheet tests to determine whether there was a reasonable CPC processing window (i.e. a suitable range of stoichiometric acid addition factors). In addition, a Glycolic-nitric flowsheet test was completed with each slurry (GF-40 and 41).

The main objective of these runs was to determine if a CPC processing window could be found where the SRAT product nitrite is $<1000 \mathrm{mg} / \mathrm{kg}$ and hydrogen generation peak is less than 0.65 $\mathrm{lb} / \mathrm{hr}$ in the SRAT and less than $0.223 \mathrm{lb} / \mathrm{hr}$ in the SME. Generally a window of $~ 30 \%$ in the stoichiometric acid factor (such as $100-130 \%$ ) is the minimum required in the CPC. With the 
SRNL-STI-2012-00018

Revision 1

stoichiometric acid factor (such as $100-130 \%$ ) is the minimum required in the CPC. With the baseline flowsheet, the width of the processing window is primarily determined by the noble metal concentrations and the stoichiometric acid demand. The higher the noble metals and/or acid demand, the smaller the window. In this testing of the baseline flowsheet, two levels of noble metals were planned, SB7A in round 1 and HM levels of noble metals in round 2 . Round 2 was not completed due to high hydrogen generation in round 1.

In order to destroy the nitrite in the SRAT cycle, and have the large hydrogen peak in the SRAT, which has a higher hydrogen limit and a higher purge, a higher acid stoichiometry is needed. Of course the less washed sludges have higher nitrite concentrations and other species that need reduction/destruction requiring more acid to complete the reactions. Processing the less washed sludges with the Glycolic-Nitric flowsheet produces little hydrogen, so the likelihood of a wide window is much greater. A list of these tests is included in Table 3-42.

Table 3-42. Testing with Less Washed Sludge Simulants

\begin{tabular}{|lcccc|}
\hline Run & Sludge & $\begin{array}{c}\text { Acid } \\
\text { Stoichiometry }\end{array}$ & $\begin{array}{c}\text { Peak SRAT H } \\
\text { lb/hr }\end{array}$ & $\begin{array}{c}\text { Peak SME } \mathrm{H}_{2}, \\
\text { lb/hr }\end{array}$ \\
\hline Baseline Na2-1 & $1.6 \mathrm{M} \mathrm{Na}$ & 130 & $2.76 \mathrm{E}-3$ & $1.8 \mathrm{E}-3$ \\
\hline GF40 & $1.6 \mathrm{M} \mathrm{Na}$ & 130 & $1.98 \mathrm{E}-5$ & $1.04 \mathrm{E}-5$ \\
\hline Baseline Na2.5-1 & $1.9 \mathrm{M} \mathrm{Na}$ & 130 & $5.96 \mathrm{E}-3$ & $2.01 \mathrm{E}-3$ \\
\hline GF41 & $1.9 \mathrm{M} \mathrm{Na}$ & 130 & $2.20 \mathrm{E}-5$ & $0.00 \mathrm{E} 0$ \\
\hline
\end{tabular}

Baseline flowsheet testing with 100,125 and 130\% Koopman stoichiometry were not successful in meeting DWPF process requirements. The $100 \%$ acid stoichiometry test failed because the nitrite was only partially destroyed. The $125 \%$ and $130 \%$ runs failed due to high hydrogen generation in the SME cycle. The only successful test was the $110 \%$ acid stoichiometry test. If there is a viable window, it is likely between $110 \%$ and $120 \%$ so it is too small for CPC processing. Approximately $10 \%$ additional acid above the stoichiometric prediction was required to destroy nitrite due to the high oxalate concentration. Note that none of the current acid equations include a term for oxalate, though a significant impact was thoroughly documented in preliminary studies for Sludge Batch $3^{23}$.

Both Glycolic-Nitric Flowsheet Tests at 130\% Koopman stoichiometry were successful in destroying nitrite and minimizing the hydrogen generation. No lower acid stoichiometry testing was completed as the less washed slurries were consumed in this testing, but it is likely the window would have been from $110 \%$ to $200 \%$ based on previous testing. Hydrogen was detected in these runs but it was approximately $1 \%$ of the peak hydrogen in the Baseline flowsheet runs. As mentioned earlier, it was likely detected only because a lower SRAT air purge was used.

Based on this testing, processing of the less washed sludges with the Glycolic-Nitric Flowsheet is viable. The optimum processing conditions are likely closer to $110 \%$ acid stoichiometry since more metals will be dissolved during processing as more acid is used. For example, $30-40 \%$ of the iron was soluble by the time the SME cycle was complete in GF40 and GF41 testing. This could lead to a SME product that is not sufficiently viscous to hold the frit in suspension.

\subsubsection{Lower Air Purge in SRAT}

Because of the lower hydrogen generation during Glycolic-Nitric Acid Flowsheet processing, DWPF is considering lowering the purge in the SRAT. At present, to control flammability, DWPF maintains a SRAT air purge of $230 \mathrm{scfm}$ to ensure the purge is at least $190 \mathrm{scfm}(230 \mathrm{scfm}$ with 
instrument uncertainty) to control flammability. Even with no catalytic hydrogen generation, the SRAT needs an air purge to dilute the Isopar added with the MCU organic species. Calculations by DWPF-E demonstrate that the purge can be reduced to $93.7 \mathrm{scm}^{24}$ with the Glycolic-Nitric Acid Flowsheet. This lower purge was tested in GF34b and GF34c tests and was utilized in the GF40 and 41 testing. Data from these runs will be compared in the following analysis.

The main impact of lowering the purge is that the measured concentrations of the process-generated gases are higher in the Glycolic Flowsheet. However, converting the data to DWPF lb/hr basis allows an easier comparison of the runs. The nitrous oxide profiles are summarized in Figure 3-27. Note that the $\mathrm{N}_{2} \mathrm{O}$ profiles look very similar for runs GF34, GF34b and GF34c, so there is no impact on $\mathrm{N}_{2} \mathrm{O}$ generation.

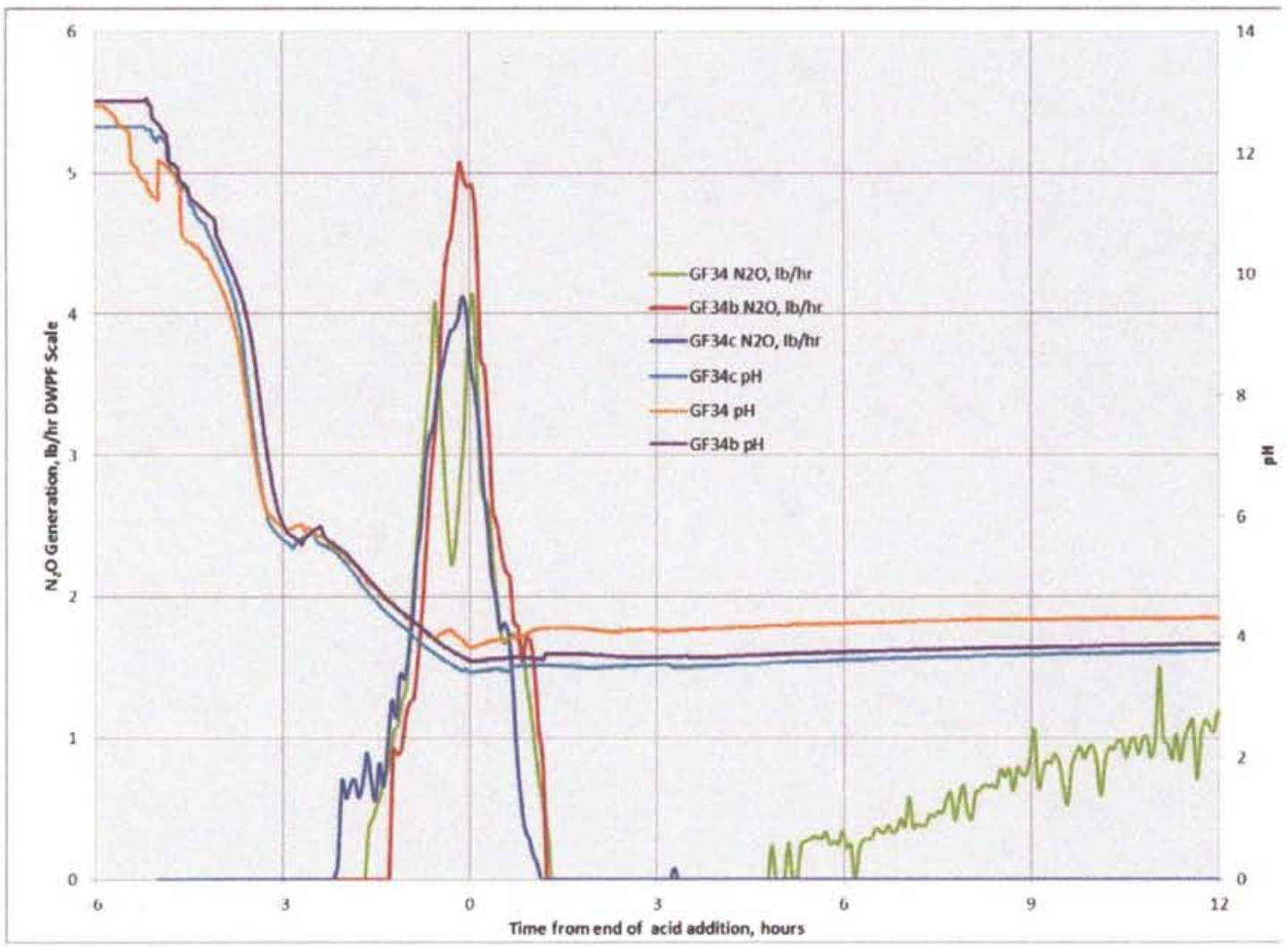

Figure 3-27. Nitrous Oxide Profile, lb/hr 
Hydrogen was detected in only one pair of Glycolic-Nitric runs, GF40 and 41, with an apparent quantitation limit of 0.005 volume $\%$. The maximum hydrogen concentration at the lower purge was 0.009 volume $\%$. These concentrations would have been below the quantitation limit using the typical air purge. The peak hydrogen generation rates in runs GF40 and GF41 were 0.00287 and $0.00324 \mathrm{lb} / \mathrm{hr}$ respectively. The peak hydrogen generation rates in Baseline flowsheet runs $2 \mathrm{M}-1$ and $2.5 \mathrm{M}-1$ were 0.403 and $0.699 \mathrm{lbs} / \mathrm{hr}$ respectively, 140 and 210 times higher respectively than similar Glycolic-Nitric Flowsheet runs. Lowering the purge likely has no impact on hydrogen generation other than to lower the detection limit.

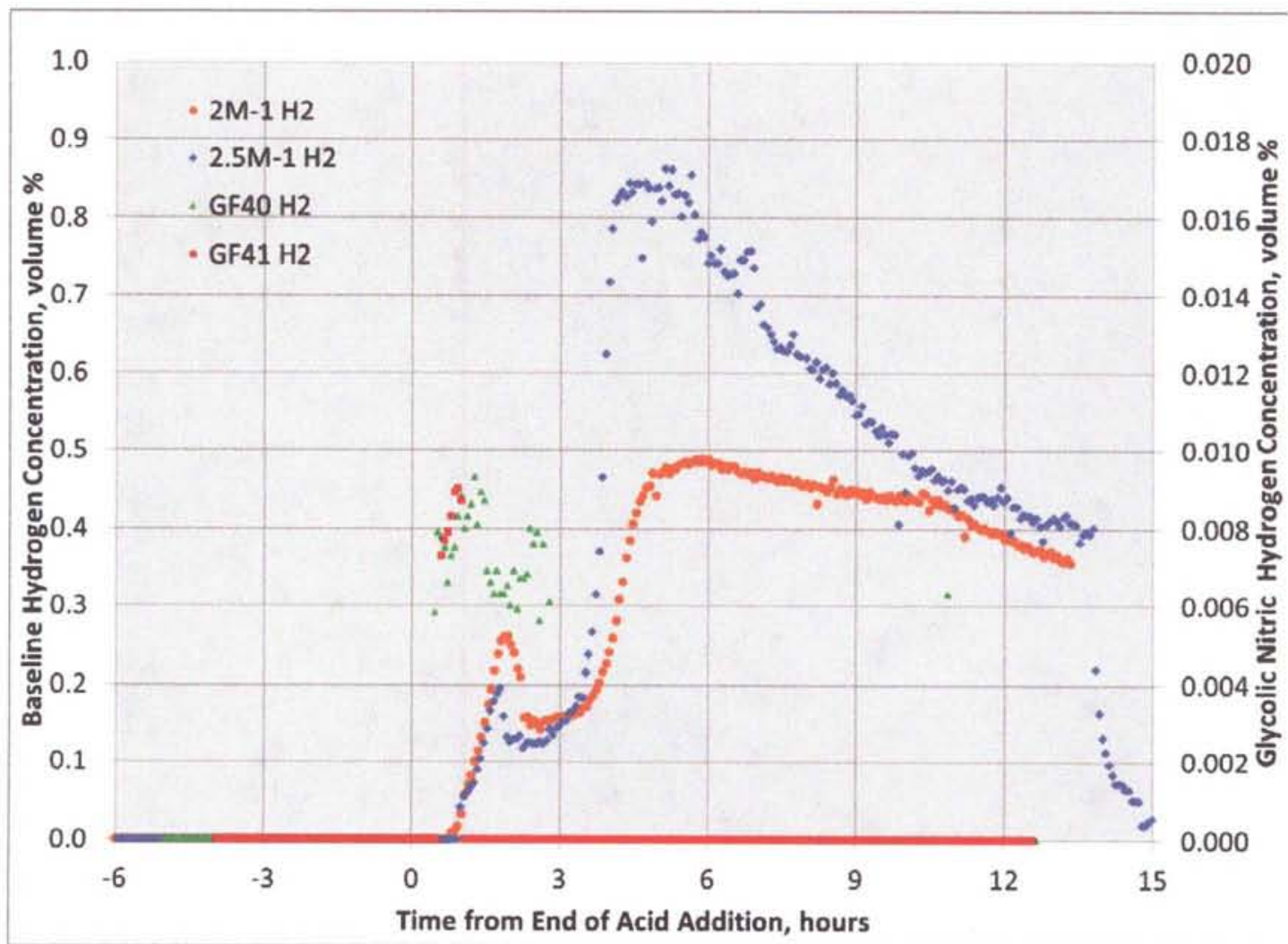

Figure 3-28. Glycolic-Nitric and Baseline Flowsheet SRAT Hydrogen Concentration Profile, volume \% 
The production of carbon dioxide during Runs GF34, GF34b and GF34c have very similar profiles on a $\mathrm{lb} / \mathrm{hr}$ scale, From this data, there was no impact on carbon dioxide generation from lowering the air purge. Figure 3-29 is a graph of carbon dioxide during the SRAT cycle. The $\mathrm{CO}_{2}$ generated in Glycolic-Nitric Flowsheet runs is approximately one-third compared to Baseline Flowsheet runs.

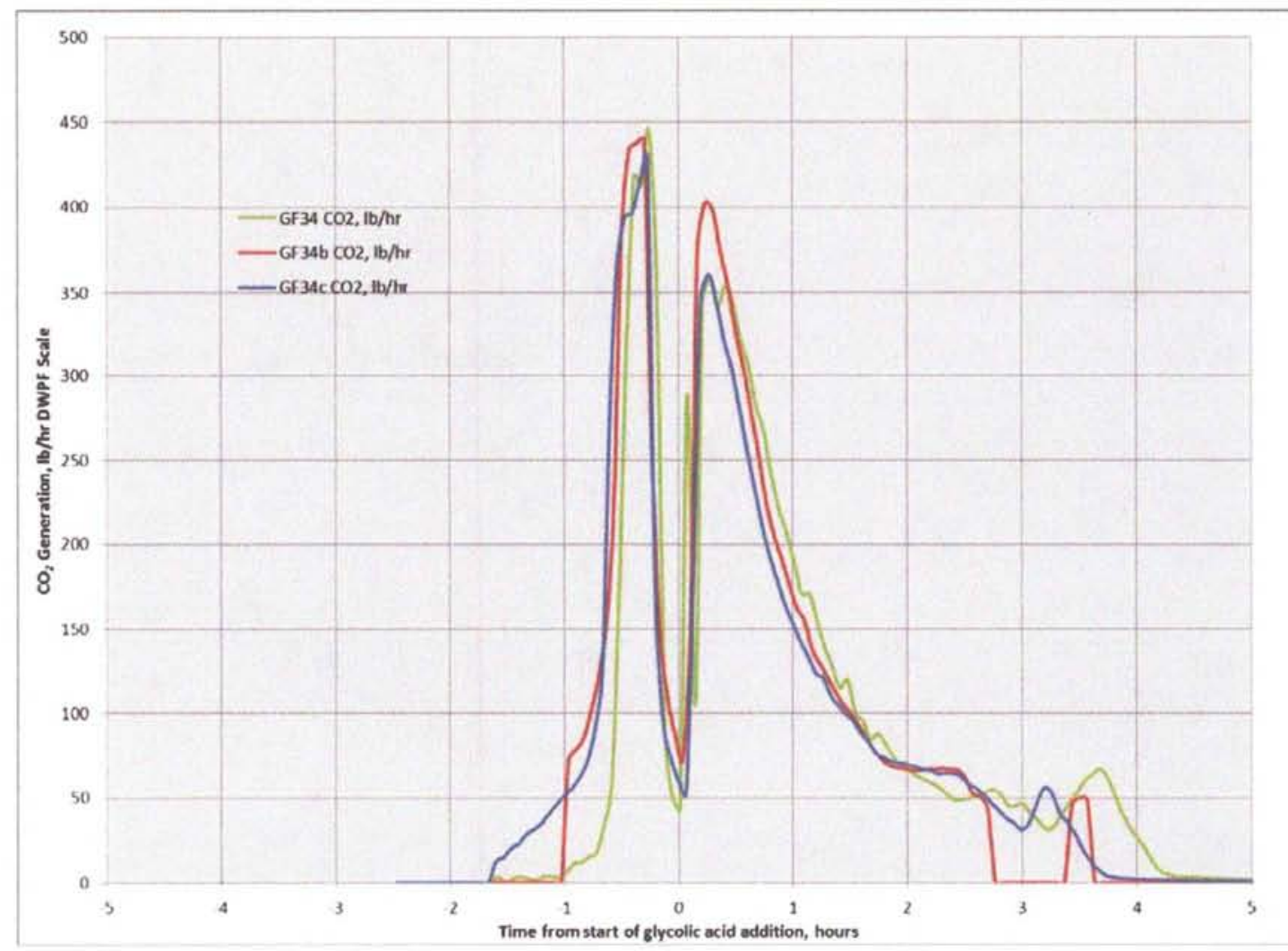

Figure 3-29. Carbon Dioxide Profile, lb/hr

During acid addition and boiling, oxygen is consumed by the oxidation of $\mathrm{NO}$ to $\mathrm{NO}_{2}$. With the lower purge in the Glycolic-Nitric Flowsheet runs, the oxygen is completely depleted during the nitrite destruction phase of the SRAT cycle and remains depleted for several hours. Note that GF34 had a scaled air purge of $230 \mathrm{scfm}, \mathrm{GF} 34 \mathrm{~b}$ had a scaled air purge of $190 \mathrm{scfm}$ and GF34c had a scaled air purge of $93.7 \mathrm{scfm}$. Figure 3-30 shows the lower oxygen (completely depleted) in the runs with the lower purge. 


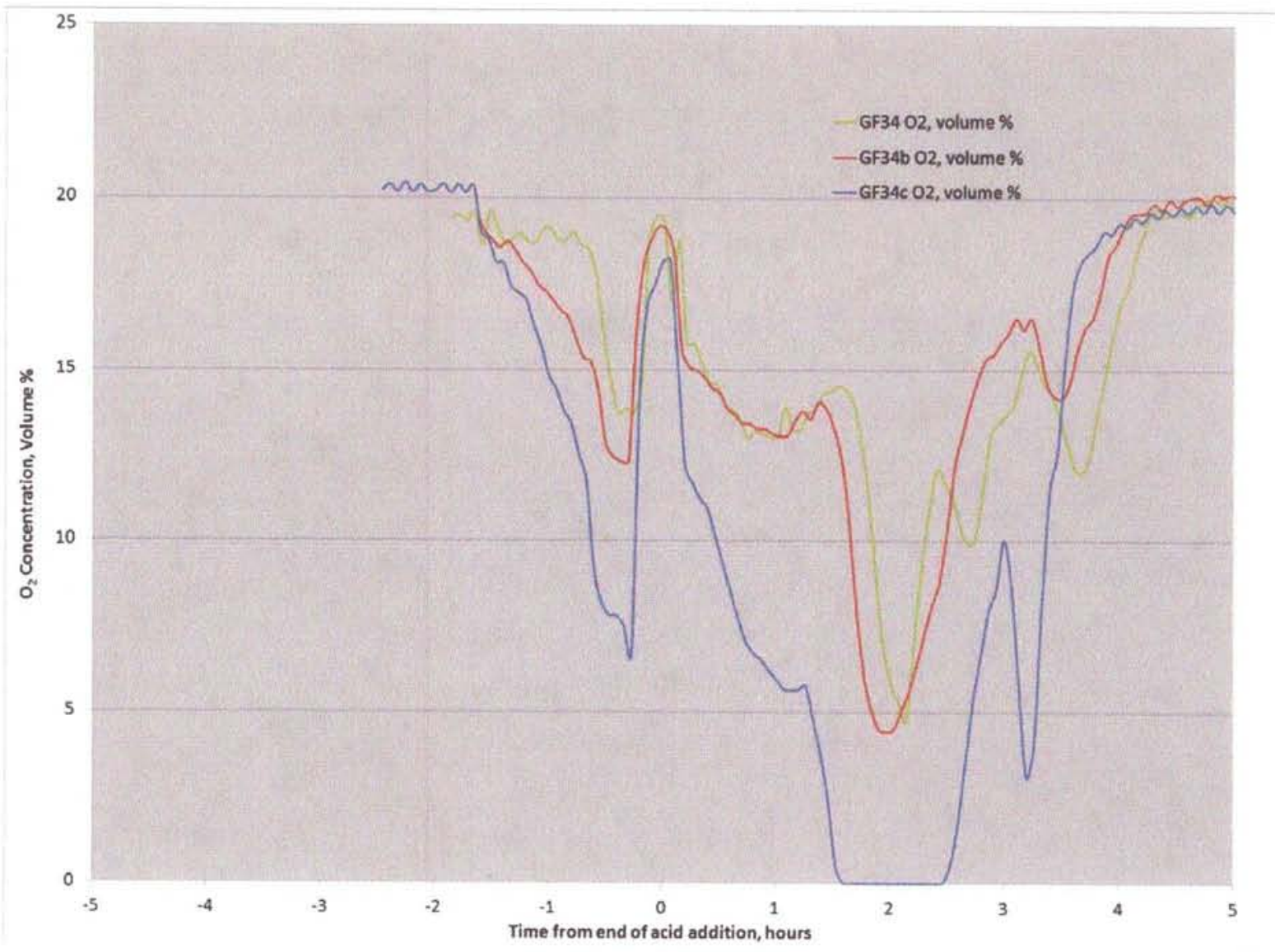

Figure 3-30. Oxygen Profile, Volume \%

\subsubsection{Addition of Acid during Heat-up}

One way to decrease the acid addition time during SRAT processing is to add the acid earlier in the SRAT cycle. There are several places this could be accomplished, including during heat-up prior to ARP addition and during heat-up prior to acid addition. In runs GF40 and GF41, nitric acid was added during heat-up to $93^{\circ} \mathrm{C}$. No processing issues were noted during this early acid addition. The first part of the acid addition is a neutralization of the soluble base species in the sludge with nitric acid so no impact was anticipated. It is recommended that all future processing utilize this productivity enhancement.

\subsubsection{Closing Reflux Valve during Acid Addition}

One way to decrease the SRAT dewater time is to close the reflux valve throughout acid addition. Condensate is generated during acid addition and a portion of the dewater can be collected during acid addition. The condensate generated during acid addition is very acidic due to generation of NO, oxidation to $\mathrm{NO}_{2}$ and scrubbing $\mathrm{NO}_{2}$ in the condenser and scrubber. Runs GF40 and 41 were designed to compare the Glycolic-Nitric Acid flowsheet to the Baseline Flowsheet using underwashed $2.0 \mathrm{M}$ and $2.5 \mathrm{M} \mathrm{Na}$ sludge simulants. In both glycolic acid runs, the mercury collection was significantly higher than the comparable Baseline flowsheet runs (2MNa-1 and 
2.5MNa-1). The results are summarized in Table $3-43$. It is recommended that the reflux valve remain closed during future Glycolic-Nitric Acid Flowsheet runs.

Table 3-43. MWWT Mercury Recovery for Runs GF40, 41, 2.0MNa, 2.5M Na

\begin{tabular}{|lcccc|}
\hline Run & GF40 & GF41 & $\mathbf{2 . 0 M ~ N a - 1}$ & $\mathbf{2 . 5 M ~ N a - 1}$ \\
\hline Sludge & $2.0 \mathrm{M} \mathrm{Na}$ & $2.5 \mathrm{M} \mathrm{Na}$ & $2.0 \mathrm{M} \mathrm{Na}$ & $2.5 \mathrm{M} \mathrm{Na}$ \\
\hline Hg Recovered, g & 3.083 & 2.697 & 2.268 & 1.790 \\
\hline
\end{tabular}

\subsubsection{Processing without Formic Acid in the Frit Slurry}

The addition of formic acid in the frit slurry causes the production of significant hydrogen in the SME cycle. Tests GF40 and GF41 were completed without adding formic acid during SME frit addition. This eliminated the production of hydrogen during the SME cycle. It is recommended that future processing of the Glycolic-Formic Acid Flowsheet eliminate the use of formic acid and use either nitric or glycolic acid if needed as an anticlumping/antigeling agent in the frit slurry.

\subsubsection{Future Processing Improvements}

A number of processing changes should be considered to improve CPC processing in DWPF. These could be tested in future experiments and includes:

- Switch acid addition order for improved mercury recovery. VSL found that adding nitric, then glycolic followed by the rest of the nitric acid led to better mercury removal.

- Adding acids at boiling to improve dewater collection during acid addition and mercury recovery. Determine optimum time for boiling to begin.

- Add acids to SRAT before ARP addition to reduce $\mathrm{pH}$ of SRAT and maximize effectiveness of antifoam. This should minimize the antifoam addition volume.

- Determine optimum acid stoichiometry for mercury recovery.

- Determine the optimum total solids and waste loading to hinder settling of frit during dilution by pump priming in Melter Feed Tank.

\subsection{Conclusions}

Testing was completed to demonstrate the viability of the newly developed glycolic/nitric flowsheet for processing in the Defense Waste Processing Facility's (DWPF) Chemical Process Cell (CPC). The Savannah River National Laboratory (SRNL) initiated a sludge matrix study to evaluate the impact on CPC processing. Four sludge simulants were designed to cover a broad insoluble solid composition range to bracket future sludge batches. The first pair of sludge parameters was high iron/low aluminum versus low iron/high aluminum (referred to as $\mathrm{HiFe}$ or LoFe in this report). The second pair of sludge parameters was high calcium-manganese/low nickel, chromium, and magnesium versus low calcium-manganese/high nickel, chromium, and magnesium (referred to as $\mathrm{HiMn}$ or LoMn in this report). In addition, a simple supernate simulant was prepared to match the composition of the matrix simulants.

Ten experiments (GF34 to GF37 and GF34b, GF34c, GF36b, GF36c, GF37b and GF38) were completed to demonstrate the glycolic-nitric flowsheet viability using the sludge matrix simulants. In addition, two experiments were performed with less washed simulants (GF40,2M and GF41, 2.5 $\mathrm{M} \mathrm{Na}$ endpoints) to demonstrate the viability of processing these sludges. Also, five supernate 
experiments (GF39a-GF39eGF39e) were performed to better understand the reaction sequence, particularly the reduction and stripping of mercury.

Composition and physical property measurements were made on the Sludge Receipt and Adjustment Tank (SRAT) and Slurry Mix Evaporator (SME) products. Composition measurements were made on the composited condensates from the Mercury Water Wash Tank (MWWT), and Formic Acid Vent Condenser (FAVC), on the ammonia scrubber solution, and on SRAT samples pulled throughout the SRAT cycle. Updated values for glycolate and formate loss, nitrite-to-nitrate conversion, and oxalate formation were found that can be used in the acid calculations for future process simulations with the glycolic-nitric flowsheet.

Preliminary results of the initial testing indicate:

- Hydrogen generation rate was below detection limits $(<11.4 \mathrm{E}-3 \mathrm{lb} / \mathrm{hr}$ DWPF-scale or $<0.005 \mathrm{vol} \%$ ) throughout all SRAT cycles with matrix simulants. Hydrogen generation rate was above detection limits for the less washed simulants (3.2E-3 lb/hr DWPF-scale or $0.009 \mathrm{vol} \%$ ) due to the higher acid stoichiometry and the lower offgas purge.

- Hydrogen generation rate was below $0.0258 \mathrm{lb} / \mathrm{hr}$ DWPF-scale throughout all SME cycles with matrix simulants. Hydrogen was produced in the matrix SME cycles because formic acid was added with the frit slurry. Hydrogen generation rate was above detection limits for the less washed simulant in GF40 (1.8E-3 lb/hr DWPF-scale or $0.007 \mathrm{vol} \%$ ) but was below detection limit in GF41 due to the higher acid stoichiometry and the lower offgas purge. No formic acid was added in runs GF40 and GF41.

- Mercury was both reduced and stripped without formic acid. The mercury concentration of the SRAT product was below the $0.8 \mathrm{wt} \%$ limit in eight of the runs and below $0.92 \mathrm{wt} \%$ in the other four runs.

- $\quad$ Nitrite in the SRAT product was $<100 \mathrm{mg} / \mathrm{kg}$ slurry for all runs.

- Foaminess was not an issue using the nominal antifoam addition strategy or with reduced antifoam in these tests.

- High wt \% total solids were achieved while staying within rheological limits which makes the glycolic acid/nitric acid flowsheet an improvement for processing more viscous sludges. However, there may be a tradeoff between excessive dissolution of metals and thinner rheology.

- $\quad$ The $\mathrm{pH}$ remained steady throughout processing (i.e. no $\mathrm{pH}$ rebound) potentially leading to more consistent processing during the CPC. The SRAT and SME products $\mathrm{pH}$ varied from $3.5-5.0$ for the $100 \%$ and $130 \%$ acid stoichiometry runs, significantly lower than is typical of the Baseline nitric acid/formic acid flowsheet.

- $\quad$ The testing apparatus has been significantly modified to improve processing with high viscosity slurries. Testing of the old style and new style rig identified no differences in $\mathrm{CPC}$ processing, including steam stripping of $\mathrm{Hg}$.

- $\quad$ The SRAT lower air purge was demonstrated in Run GF34c and used in GF40 and GF41. The SRAT purge can be reduced from $190 \mathrm{scfm}$ to $93.7 \mathrm{scfm}$ without negatively impacting DWPF CPC processing.

- $\quad$ Runs GF40 and 41 demonstrated that processing of less washed sludges is viable with the Glycolic-Nitric flowsheet. However, this flowsheet has not been demonstrated with ARP, MCU or actual waste. 
- $\quad$ Several processing improvements were demonstrated in these runs including adding acid during heat-up, adding both acids at higher volumetric flowrates than are currently used in DWPF, and concentrating the SRAT during acid addition. Each of these improvements has the potential to shorten CPC processing time.

\subsection{Recommendations Applying to the Glycolic-Nitric Flowsheet}

The glycolic-nitric flowsheet is recommended as a viable flowsheet alternative to the Baseline DWPF flowsheet. In the testing that has been performed to date, this flowsheet meets or outperforms the current flowsheet in minimizing off-gas generation, removing mercury, and producing a rheologically thinner product. Previous testing with glycolic/formic acid mixtures demonstrated a wide processing window regarding both the glycolic-formic ratio and acid stoichiometry. The addition of glycolic acid leads to SRAT products that are rheologically less viscous which means that more concentrated products can be produced, leading to potentially higher waste throughput per batch. In addition, the combination of lower $\mathrm{pH}$ processing and the complexing power of glycolic acid leads to the dissolution of more metals, which may minimize deposits in the CPC processing vessels and prevent the fouling of steam coils. Follow-up testing is recommended in the following areas:

- Improve glycolate and oxalate analyses. The majority of the glycolate results reported were correct. However, there are issues with anion and cation deposition on the column of the Ion Chromatograph (IC), causing higher than expected glycolate and oxalate in blanks and some samples. Both Process Science and Analytical Laboratory (PSAL) and Analytical Development (AD) have reported results that have varied significantly from expectations. Modification to the sample preparation method is likely needed to improve analytical accuracy and minimize the cleaning and replacement of the IC column. An alternative to the IC measurement of glycolate should also be considered.

- Determine the appropriate REDOX model for the glycolic-nitric flowsheet. The REDOX model may need more terms due to the more extensive reduction of some metals, including $\mathrm{Mn}$ and $\mathrm{Fe}$. In addition, accurate measurement of glycolate (and possibly oxalate) and nitrate is needed to accurately predict REDOX. REDOX testing of the matrix sludges should be repeated using acceptable frits that meet Product Composition Control System (PCCS).

- $\quad$ Testing should be completed with alternate forms of ruthenium to determine whether the elimination of the chloride added as ruthenium chloride would improve the reduction and stripping of the mercury. Comparison testing should be completed with the Baseline and glycolic-nitric flowsheets.

- $\quad$ Test the glycolic-nitric flowsheet at acid stoichiometries of less than $100 \%$. Demonstration of this flowsheet at an acid stoichiometry of $<100 \%$ is recommended and might be useful for mercury stripping.

- Demonstrate the glycolic-nitric flowsheet (previously demonstrated in SRAT cycle with 80:20 glycolic:formic acid blend) with actual waste in SRNL Shielded Cells SRAT and SME processing, to include periodic slurry sampling throughout the SRAT and SME processing along with a glass REDOX measurement.

- Add the nitric and glycolic acid flowrate at the same scaled molar flowrate as formic acid to minimize glycolic-nitric flowsheet batch time. 
- The nitric acid can be added during heat-up to decrease the SRAT cycle time. The nitric acid primarily neutralizes soluble the base species in the slurry with little offgas generation.

- Improve understanding of process chemistry, the decomposition of glycolate and the production of oxalate which are important to REDOX.

- Improve understanding of mercury reduction, stripping and accumulation during processing. Determine whether alternative equipment or processing changes are needed to maximize the collection of mercury in the Mercury Water Wash Tank.

- If confirmed by actual waste testing and larger scale testing with simulants, the antifoam addition can be reduced for this flowsheet. The addition of $100 \mathrm{mg} / \mathrm{kg}$ prior to glycolic acid addition, $100 \mathrm{mg} / \mathrm{kg}$ prior to boiling and $100 \mathrm{mg} / \mathrm{kg}$ each 12 hours of processing was adequate during simulant testing.

- More rigorous data collection is needed to validate the OLI aqueous model's solubility predictions with sample results. The methodology is summarized in the discussion.

\section{Recommendations Applying to both Baseline and Glycolic-Nitric Acid Flowsheet}

- $\quad$ Testing should be completed with alternate forms of ruthenium to determine whether the elimination of the chloride added as ruthenium chloride would improve the reduction and stripping of the mercury. Testing should be completed with the Baseline and glycolic-nitric flowsheets. 
SRNL-STI-2012-00018

Revision 1

\subsection{Acknowledgements}

The authors would like to thank a number of SRNL employees who supported this testing.

Thanks to Jon Duvall, Vickie Williams, Phyllis Workman, David Healy, Tony Burckhalter, and Beverly Walls for their excellent support during these around the clock runs.

Thanks to Whitney Riley, Beverly Walls, Phyllis Workman, Russ Eibling and Pat Simmons for their excellent and timely analysis of the hundreds of samples that were submitted as part of this study.

Thanks to Tom White, Amy Ekechukwu, and David Missmer for the AD analysis of samples for IC, TOC and XRD.

Thanks to Frances Williams and John Pareizs for their support of the GC calibration, analysis, and post run processing.

Thanks to Jack Zamecnik for his calibration, operation and post run analysis of the FTIR and MS.

Thanks to Jackie Best for her excellent administrative support. 
SRNL-STI-2012-00018

Revision 1

\subsection{Reference}

1 Pickenheim, B.R., M.E. Stone, SRAT Alternative Reductant Feasibility Assessment - Phase I, SRNLSTI-2009-00120, Savannah River National Laboratory, Aiken, SC, February 2009.

2 Pickenheim, B.R., M.E. Stone, J.D. Newell, Glycolic-Formic Acid Flowsheet Development, SRNLSTI-2010-00523, Rev 0, Savannah River National Laboratory, Aiken, SC, November 2010.

3 D.P. Lambert, B.R. Pickenheim, M.E. Stone, J.D. Newell, D.R. Best, Glycolic - Formic Acid Flowsheet Final Report for Downselection Decision, SRNL-STI- 2010-00523, Rev 1, Savannah River National Laboratory, Aiken, SC, March 2011.

4 Fellinger, T.L., "Alternate Reductant Flowsheet Development-Phase I', HLW-DWPF-TTR-20120003, Revision 0, October 2011.

5 Lambert, D.P., Task Technical and Quality Assurance Plan for Glycolic Acid Flowsheet Development, SRNL-RP-2011-01586, Savannah River National Laboratory, Aiken, SC, November 2011.

6 D. C. Koopman, D. P. Lambert, Initial Characterizations and SRAT Simulations of Four Sludge Matrix Study Simulants, SRNL-STI-2009-00606, Revision 0, Savannah River National Laboratory, Aiken, SC, December 2009

7 Lambert, D.P., Acid Calculation Spreadsheet for DWPF Simulations, Revision 1, SRNL-PSE-200600176, Savannah River Site, Aiken, SC 29808 (2006).

8 Koopman, D.C., A.I. Fernandez, B.R. Pickenheim, Preliminary Evaluations of Two Proposed Stoichiometric Acid Equations, Revision 0, Savannah River Site, Aiken, SC 29808 (2009).

9 Stone, M. E., Lab-Scale CPC Equipment Set-up, SRNL-ITS-2006-000742011-00127, Savannah River Site, Aiken, SC 29808 (2011).

10 Manual L29, Procedure ITS-0094, Rev. 6, Laboratory Scale Chemical Process Cell Simulations, Savannah River Site, Aiken, SC 29808, November 2011.

11 Glycolic/Nitric Acid Flowsheet Development Notebook, SRNL-NB-2012-00039, Savannah River Site, Aiken, SC 29808 (2012).

12 Jantzen, C. M. and M. E. Stone, Role of Manganese Reduction/Oxidation (REDOX) on Foaming and Melt Rate in High Level Waste Melters, WSRC-STI-2006-00066, Savannah River Site, Aiken, SC, 29808 , March 2007.

13 Jantzen, C.M., J.R. Zamecnik, D.C. Koopman, C.C. Herman, and J.B. Pickett, Electron Equivalents Model for Controlling Reduction-Oxidation (REDOX) Equilibrium during High Level Waste (HLW) Vitrification, WSRC-TR-2003-00126, Savannah River Site, Aiken, SC 29808 (2003).

14 Lambert, D. P., Koopman, D. C., Glycolic-Formic Acid Flowsheet Sludge Matrix Study, SRNL-STI2011-00275, Savannah River Site, Aiken, SC, 29808 (June 2011).

15 D. C. Koopman, D. P. Lambert, Initial Characterizations and SRAT Simulations of Four Sludge Matrix Study Simulants, SRNL-STI-2009-00606, REVISION 0, Savannah River National Laboratory, Aiken, SC, December 2009.

16 Best, D.R., Anion Analysis by Ion Chromatography for the Alternate Reductant Program for the Defense Waste Processing Facility, SRNL-STI-2010-00389, Savannah River National Laboratory, Aiken, SC, June 2010.

17 Manual L29, Procedure ITS-0052, Rev. 2, Heat Treatment of Waste Slurries for REDOX $(\mathrm{Fe} 2+/ \Sigma \mathrm{Fe})$ and Chemical Composition Measurement.

18 Koopman, D. C., Noble Metal Chemistry and Hydrogen Generation during Simulated DWPF Melter Feed Preparation, WSRC-STI-2008-00002, SRNL, Aiken, SC, 29808 (June 2008).

19 Zamecnik, J.R., Behavior of Mercury during DWPF Chemical Process Cell, SRNL-STI-2012-00051, REVISION 0, Savannah River National Laboratory, Aiken, SC, April 2012.

20 (HLW-DWPF-TTR-2012-0013)

21 Koopman, D. C., Rheology Protocols for DWPF Samples, WSRC-RP-2004-00470, Savannah River Site, Aiken, SC, 29808 (October 2004).

22 Mcllmoyle, D.W., SB8 Projected Compositions Based on Latest Plans, Interoffice Communication, Savannah River Site, Aiken, SC 29808 (June 28, 2012 with attached spreadsheet, SB8 COMPOSITIONS 628 28 $12 . x \mathrm{xls})$. 
23 Herman, C.C., D.C. Koopman, D.R. Best, T.K. Snyder, M.F. Williams, Sludge Batch 3 Simulant Flowsheet Studies: Phase II SRAT/SME Results, WSRC-TR-2003-00158, Revision 0, Savannah River Site, Aiken, SC, 29808 (April 2003).

24 Fellinger, T.L., Purge for Low Purge Experiments, Interoffice Memorandum, Savannah River Site, Aiken, SC, 29808 (April 2012) 
SRNL-STI-2012-00018

Revision 1

Appendix A. Acid Spreadsheet Inputs

A-1 
Table A-1. Sludge Analyses for Acid Calculations

\begin{tabular}{|c|c|c|c|c|c|c|c|}
\hline Run \# & $\begin{array}{l}\text { GF34 } \\
\text { GF34b } \\
\text { GF34c }\end{array}$ & GF35 & $\begin{array}{l}\text { GF36 } \\
\text { GF36b } \\
\text { GF36c }\end{array}$ & $\begin{array}{l}\text { GF37 } \\
\text { GF37b } \\
\text { GF38 }\end{array}$ & GF40 & GF41 & Units \\
\hline Mass without trim chemicals & $2,900.0$ & $2,900.0$ & $2,900.0$ & $2,900.0$ & $3,038.3$ & $3,038.0$ & g slurry \\
\hline Weight \% Total Solids & 23.70 & 18.47 & 22.81 & 23.07 & 24.14 & 25.43 & $w t \%$ \\
\hline Weight $\%$ Calcined Solids & 17.81 & 13.56 & 16.95 & 16.00 & 17.01 & 17.85 & $w t \%$ \\
\hline Weight $\%$ Insoluble Solids & 16.70 & 13.01 & 16.35 & 16.05 & 16.51 & 16.97 & wt $\%$ \\
\hline Density & 1.185 & 1.144 & 1.180 & 1.176 & 1.174 & 1.215 & kg / L slurry \\
\hline Supernate density & 1.057 & 1.051 & 1.055 & 1.057 & 1.076 & 1.091 & $\mathrm{~kg} / \mathrm{L}$ supernate \\
\hline Nitrite & 17,900 & 9,605 & 17,800 & 18,100 & 13,450 & 15,750 & $\mathrm{mg} / \mathrm{kg}$ slurry \\
\hline Nitrate & 13,550 & 5,880 & 13,400 & 13,250 & 7,895 & 9,935 & $\mathrm{mg} / \mathrm{kg}$ slurry \\
\hline Formate & 0 & 0 & 0 & 0 & 0 & 0 & $\mathrm{mg} / \mathrm{kg}$ slurry \\
\hline Sulfate & 1,770 & 1,345 & 1,575 & 1,585 & 1,975 & 2,605 & $\mathrm{mg} / \mathrm{kg}$ slurry \\
\hline Chloride & 116 & 0 & 131 & 127 & 0 & 0 & $\mathrm{mg} / \mathrm{kg}$ slurry \\
\hline Phosphate & 0 & 0 & 0 & 0 & 0 & 0 & $\mathrm{mg} / \mathrm{kg}$ slurry \\
\hline Oxalate & 300 & 7,220 & 275 & 294.5 & 18750 & 20000 & $\mathrm{mg} / \mathrm{kg}$ slurry \\
\hline Slurry TIC & 2,751 & 1,066 & 2,492 & 2,403 & 1840 & 1732 & $\mathrm{mg} / \mathrm{kg}$ slurry \\
\hline Supernate TIC & 1,080 & 664 & 1,310 & 1,280 & 1790 & 1760 & $\mathrm{mg} / \mathrm{L}$ supernate \\
\hline Base Equivalents) $\mathrm{pH}=7$ & 0.5903 & 0.580 & 0.562 & 0.522 & 0.838 & 0.879 & MolesBase/L slurry \\
\hline Coal/Carbon source & 0.000 & 0.000 & 0.000 & 0.000 & 0.000 & 0.000 & wt $\%$ dry basis \\
\hline Manganese & 4.040 & 5.115 & 0.690 & 0.662 & 4.625 & 4.230 & wt $\%$ calcined basis \\
\hline Mercury & 0.0000 & 0.0000 & 0.0000 & 0.0000 & 0.0000 & 0.0000 & wt $\%$ dry basis \\
\hline Magnesium & 0.448 & 0.413 & 2.970 & 2.420 & 0.286 & 0.264 & wt $\%$ calcined basis \\
\hline Sodium & 12.500 & 14.700 & 12.900 & 14.200 & 23.290 & 23.986 & wt $\%$ calcined basis \\
\hline Potassium & 0.110 & 0.120 & 0.076 & 0.096 & 0.345 & 0.407 & wt $\%$ calcined basis \\
\hline Cesium & 0.000 & 0.000 & 0.000 & 0.000 & 0.000 & 0.000 & wt $\%$ calcined basis \\
\hline Calcium & 3.840 & 0.831 & 2.115 & 1.970 & 0.576 & 0.514 & wt $\%$ calcined basis \\
\hline Strontium & 0.000 & 0.000 & 0.000 & 0.000 & 0.000 & 0.000 & wt $\%$ calcined basis \\
\hline Nickel & 0.214 & 3.310 & 2.600 & 2.310 & 1.937 & 1.756 & wt $\%$ calcined basis \\
\hline Supernate Manganese & 0 & 0 & 0 & 0 & 0 & 0 & $\mathrm{mg} / \mathrm{L}$ supernate \\
\hline
\end{tabular}


Table A-2. SRAT Processing Assumptions

\begin{tabular}{|c|c|c|c|c|c|c|c|c|c|}
\hline Run \# & $\begin{array}{l}\text { GF34 } \\
\text { GF34b } \\
\text { GF34c }\end{array}$ & GF35 & $\begin{array}{l}\text { GF36 } \\
\text { GF36b } \\
\text { GF36c }\end{array}$ & $\begin{array}{l}\text { GF37 } \\
\text { GF37b }\end{array}$ & & GF38 & GF40 & GF41 & Units \\
\hline $\begin{array}{l}\text { Conversion of Nitrite to Nitrate } \\
\text { in SRAT Cycle }\end{array}$ & 30.00 & 30.00 & 30.00 & 30.00 & 30.00 & 30.00 & 30.00 & 30.00 & $\begin{array}{l}\text { gmol } \\
\text { gmol } \mathrm{NO}_{2}^{-}\end{array} \mathrm{NO}_{3}^{-} / 100$ \\
\hline $\begin{array}{l}\text { Destruction of Nitrite in SRAT } \\
\text { and SME cycle }\end{array}$ & 100.00 & 100.00 & 100.00 & 100.00 & 100.00 & 100.00 & 100.00 & 100.00 & $\begin{array}{l}\% \text { of starting nitrite } \\
\text { destroyed }\end{array}$ \\
\hline $\begin{array}{l}\text { Destruction of Formic acid } \\
\text { charged in SRAT }\end{array}$ & 0.00 & 0.00 & 0.00 & 0.00 & 0.00 & 0.00 & 0.00 & 0.00 & $\begin{array}{l}\% \\
\text { converted to } \mathrm{CO}_{2} \\
\text { etc. }\end{array}$ \\
\hline $\begin{array}{l}\text { Destruction of Glycolic acid } \\
\text { charged in SRAT }\end{array}$ & 30.00 & 30.00 & 30.00 & 30.00 & 30.00 & 30.00 & 30.00 & 30.00 & $\begin{array}{ll}\% & \text { glycolate } \\
\text { converted to } \mathrm{CO}_{2} \\
\text { etc. }\end{array}$ \\
\hline $\begin{array}{l}\text { Conversion of Glycolic acid to } \\
\text { Oxalate }\end{array}$ & 3.00 & 3.00 & 3.00 & 3.00 & 3.00 & 3.00 & 3.00 & 3.00 & $\begin{array}{l}\% \text { glycolate } \\
\text { converted to } \mathrm{C} 2 \mathrm{O} 4\end{array}$ \\
\hline Destruction of Oxalate charged & 0.00 & 0.00 & 0.00 & 0.00 & 0.00 & 0.00 & 0.00 & 0.00 & $\begin{array}{l}\% \text { of total oxalate } \\
\text { destroyed }\end{array}$ \\
\hline $\begin{array}{l}\text { Percent Acid in Excess } \\
\text { Stoichiometric Ratio }\end{array}$ & 103.97 & 100.00 & 106.07 & 100.00 & 100.00 & 125.00 & 133.92 & 130.00 & $\%$ \\
\hline SRAT Product Target Solids & 27.90 & 27.90 & 27.90 & 27.90 & 27.90 & 27.90 & 27.90 & 27.90 & $\%$ \\
\hline Nitric Acid Molarity & 10.304 & 10.304 & 10.304 & 10.304 & 10.304 & 10.304 & 10.312 & 10.312 & Molar \\
\hline Formic Acid Molarity & 23.552 & 23.552 & 23.552 & 23.552 & 23.552 & 23.552 & 23.552 & 23.552 & Molar \\
\hline Glycolic Acid Molarity & 11.930 & 11.930 & 11.930 & 11.930 & 11.847 & 11.847 & 11.441 & 11.441 & Molar \\
\hline DWPF Nitric Acid addition Rate & 4.572 & 4.572 & 4.572 & 4.572 & 4.572 & 4.572 & 4.568 & 4.568 & gallons per minute \\
\hline REDOX Target & 0.100 & 0.100 & 0.100 & 0.100 & 0.100 & 0.100 & 0.100 & 0.100 & $\mathrm{Fe}^{+2} / \Sigma \mathrm{Fe}$ \\
\hline Ag metal & 0.0014 & 0.0014 & 0.0014 & 0.0014 & 0.0014 & 0.0014 & 0.0144 & 0.0135 & total wt $\%$ dry basis \\
\hline wt $\%$ Hg dry basis & 1.5000 & 1.5000 & 1.5000 & 1.5000 & 1.5000 & 1.5000 & 1.5000 & 1.4095 & total wt $\%$ dry basis \\
\hline Pd metal & 0.0790 & 0.0790 & 0.0790 & 0.0790 & 0.0790 & 0.0790 & 0.0033 & 0.0031 & total wt $\%$ dry basis \\
\hline Rh metal & 0.0380 & 0.0380 & 0.0380 & 0.0380 & 0.0380 & 0.0380 & 0.0192 & 0.0180 & total wt $\%$ dry basis \\
\hline Ru metal & 0.2170 & 0.2170 & 0.2170 & 0.2170 & 0.2170 & 0.2170 & 0.0877 & 0.0824 & total wt $\%$ dry basis \\
\hline Oxalate & 0.1235 & 3.8086 & 0.1176 & 0.1246 & 0.1246 & 0.1246 & 7.6001 & 7.7045 & total wt $\%$ dry basis \\
\hline Dilution Water & 250.00 & 250.00 & 250.00 & 250.00 & 250.00 & 250.00 & 250.00 & 250.00 & $\mathrm{~g}$ \\
\hline
\end{tabular}




\begin{tabular}{|l|c|c|c|c|c|c|c|c|c|}
\hline Run \# & $\begin{array}{l}\text { GF34 } \\
\text { GF34b } \\
\text { GF34c }\end{array}$ & GF35 & $\begin{array}{l}\text { GF36 } \\
\text { GF36b } \\
\text { GF36c }\end{array}$ & $\begin{array}{l}\text { GF37 } \\
\text { GF37b }\end{array}$ & GF38 & GF40 & GF4l & Units \\
\hline Acid flush water & 20.00 & 20.00 & 20.00 & 20.00 & 20.00 & 20.00 & 20.00 & 20.00 & $\mathrm{~g}$ \\
\hline Mass of SRAT cycle samples & 450.00 & 450.00 & 450.00 & 450.00 & 450.00 & 450.00 & 500.00 & 500.00 & $\mathrm{~g}$ \\
\hline $\begin{array}{l}\text { Active Agent In Antifoam } \\
\text { Solution }\end{array}$ & 10 & 10 & 10 & 10 & 10 & 10 & 10 & 10 & wt $\%$ \\
\hline $\begin{array}{l}\text { Basis Antifoam Addition for } \\
\text { SRAT }\end{array}$ & 100 & 100 & 100 & 100 & 100 & 100 & 100 & 100 & $\mathrm{mg} / \mathrm{kg}$ slurry \\
\hline $\begin{array}{l}\text { Number of basis antifoam } \\
\text { additions }\end{array}$ & 8 & 8 & 8 & 8 & 8 & 8 & 8 & 8 & \\
\hline SRAT air purge & 230 & 230 & 230 & 230 & 230 & 230 & 93.7 & 93.7 & scfm \\
\hline SRAT boil-up rate & 5000 & 5000 & 5000 & 5000 & 5000 & 5000 & 5000 & 5000 & $\mathrm{Ibs} / \mathrm{hr}$ \\
\hline SRAT total boil-up (reflux) & 60,000 & 60,000 & 60,000 & 60,000 & 60,000 & 60,000 & 60,000 & 60,000 & $\mathrm{Ibs}$ \\
\hline SRAT Steam Stripping Factor & 750 & 750 & 750 & 750 & 750 & 750 & 750 & 750 & $\mathrm{~g}$ steam/g mercury \\
\hline
\end{tabular}


Table A-3. SME Processing Assumptions

\begin{tabular}{|c|c|c|c|c|c|c|c|}
\hline Run \# & GF34 & GF35 & GF36 & GF37 & GF40 & GF41 & Units \\
\hline Frit type & 418 & 418 & 418 & 418 & 418 & 418 & \\
\hline Destruction of Formic acid in SME & 0 & 0 & 0 & 0 & 0 & 0 & $\begin{array}{l}\% \text { Formate converted to } \mathrm{CO}_{2} \\
\text { etc. }\end{array}$ \\
\hline Destruction of Nitrate in SME & 5 & 5 & 5 & 5 & 5 & 5 & $\%$ Nitrate destroyed in SME \\
\hline Destruction of Glycolate in SME & 5 & 5 & 5 & 5 & 5 & 5 & $\begin{array}{l}\% \text { glycolate converted to } \mathrm{CO}_{2} \\
\text { etc. }\end{array}$ \\
\hline Assumed SME density & 1.40 & 1.40 & 1.40 & 1.40 & 1.440 & 1.440 & $\mathrm{~kg} / \mathrm{L}$ \\
\hline $\begin{array}{l}\text { Basis Antifoam Addition for SME } \\
\text { cycle }\end{array}$ & 100 & 100 & 100 & 100 & 100 & 100 & $\mathrm{mg} / \mathrm{kg}$ slurry \\
\hline $\begin{array}{l}\text { Number of basis antifoam additions } \\
\text { added }\end{array}$ & 3 & 3 & 3 & 3 & 3 & 3 & \\
\hline $\begin{array}{l}\text { Sludge Oxide Contribution (Waste } \\
\text { Loading) }\end{array}$ & 36 & 36 & 36 & 36 & 36 & 36 & $\%$ \\
\hline Frit Slurry Formic Acid Ratio & 1.50 & 1.50 & 1.50 & 1.50 & 1.50 & 1.50 & g $90 w t \%$ FA/ 100 g Frit \\
\hline Target SME Solids total $\mathrm{Wt}^{\circ} \%$ & 45 & 45 & 45 & 45 & 45 & 45 & wt $\%$ \\
\hline Number of frit additions in SME Cycle & 2 & 2 & 2 & 2 & 2 & 2 & \\
\hline \# DWPF Canister decons simulated & 0.0 & 0.0 & 0.0 & 0.0 & 0 & 0 & \\
\hline Volume of water per deconed can & 1,000 & 1,000 & 1,000 & 1,000 & 1,000 & 1,000 & gal at DWPF scale \\
\hline $\begin{array}{c}\text { Water flush volume after frit slurry } \\
\text { addition }\end{array}$ & 0.0 & 0.0 & 0.0 & 0.0 & 0.0 & 0.0 & gal \\
\hline SME air purge & 74 & 74 & 74 & 74 & 74 & 74 & scfm \\
\hline
\end{tabular}


SRNL-STI-2012-00018

Revision 1

\section{Appendix B. Offgas Results}

Raw off-gas data from the GCs are presented in this Appendix for the twelve SRAT cycles and six SME cycles from the process simulations with slurry simulants. 


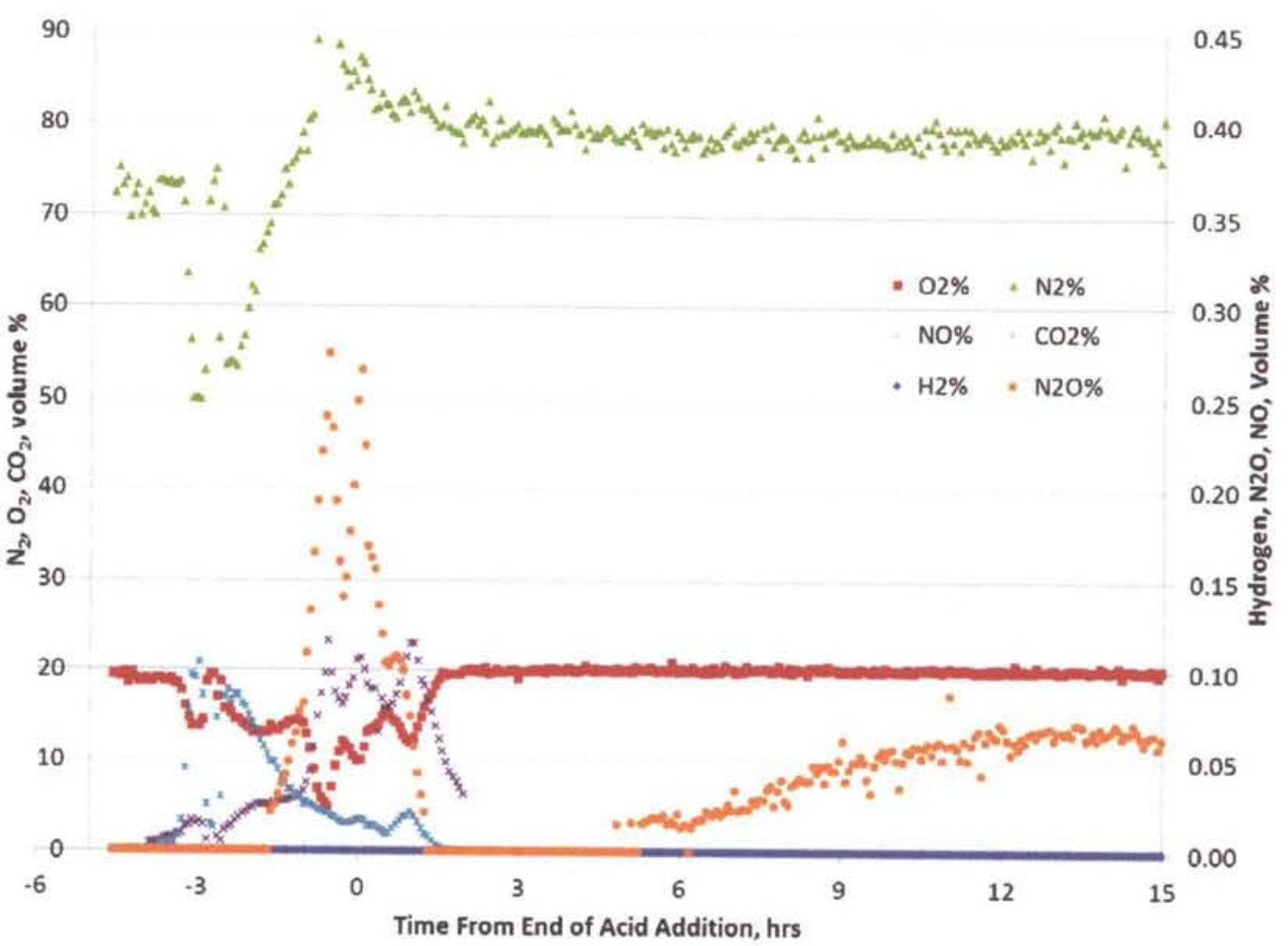

Figure B-1.GF34 SRAT Off-gas Data

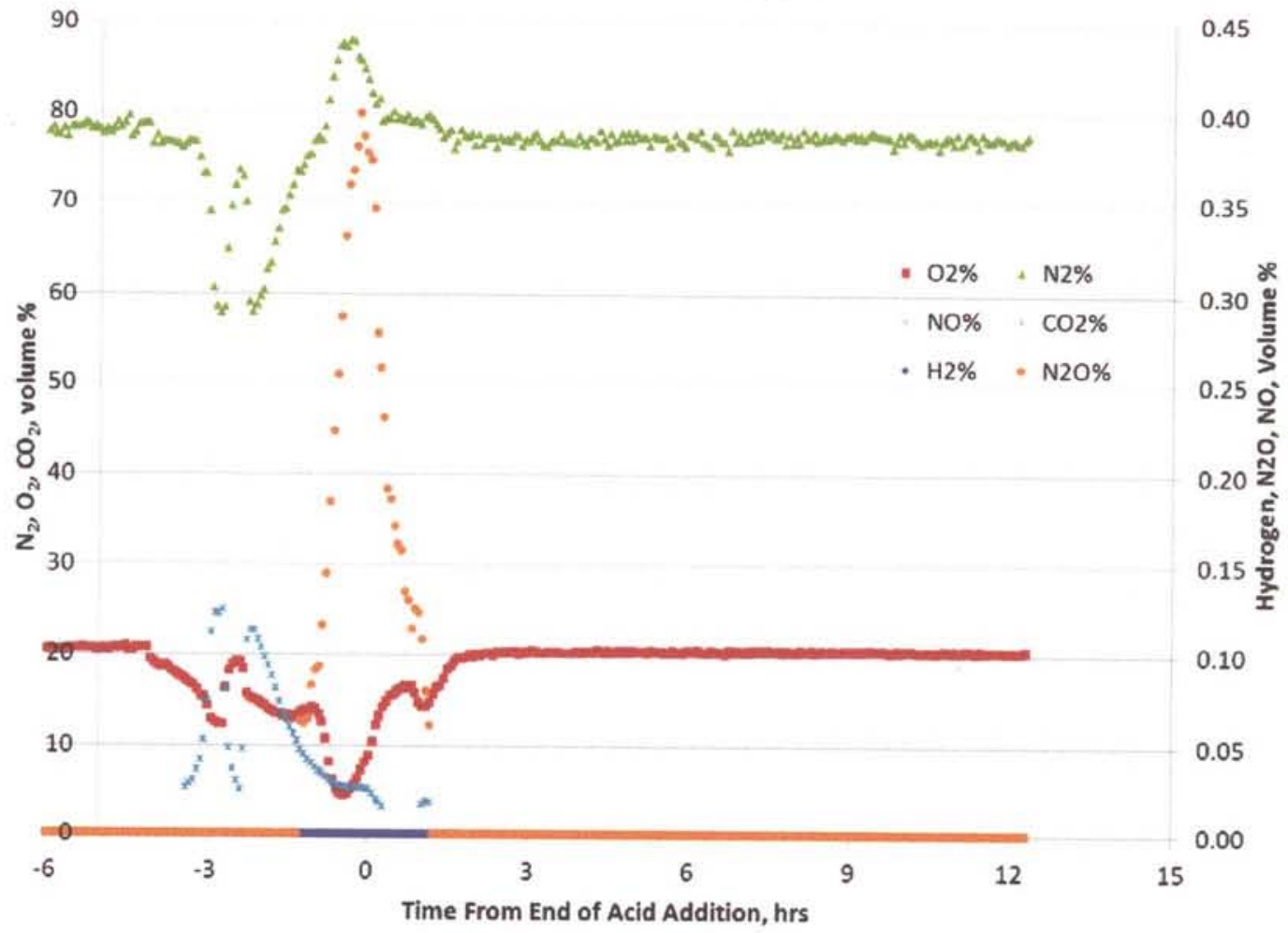

Figure B-2. GF34b SRAT Off-gas Data

B-2 
SRNL-STI-2012-00018

Revision 1

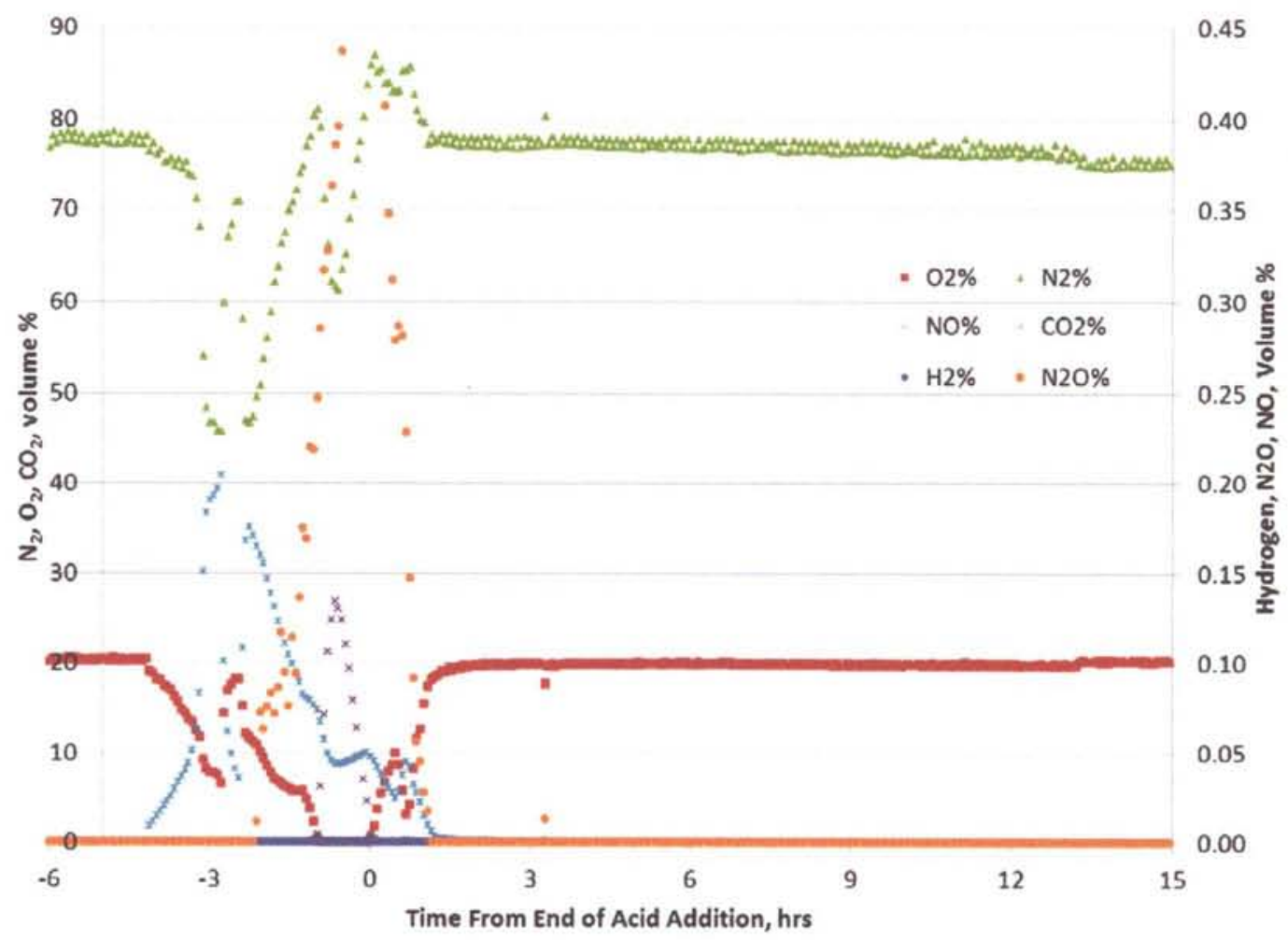

Figure B-3. GF34c SRAT Off-gas Data

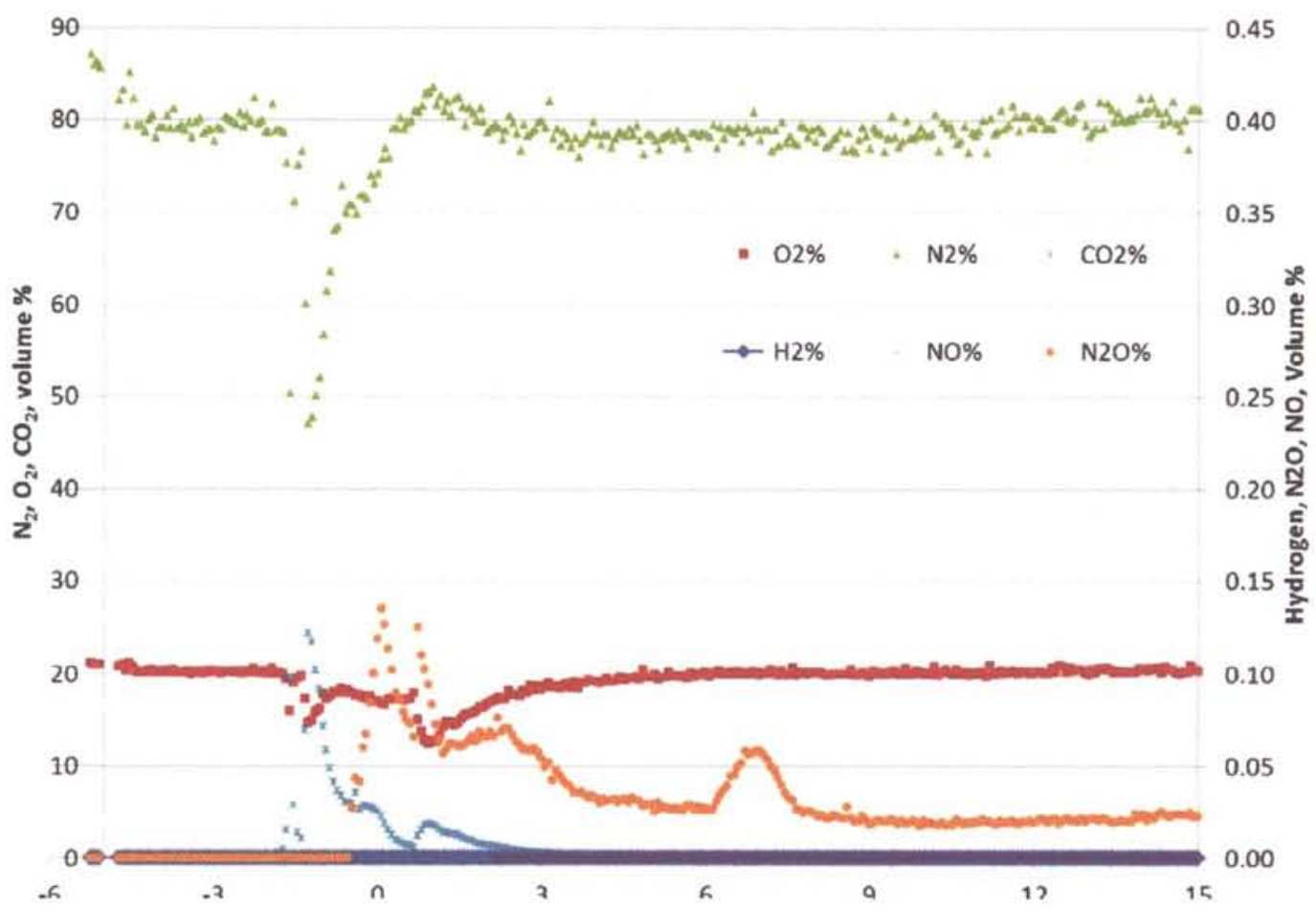

Figure B-4. GF35 SRAT Off-gas Data 
SRNL-STI-2012-00018

Revision 1

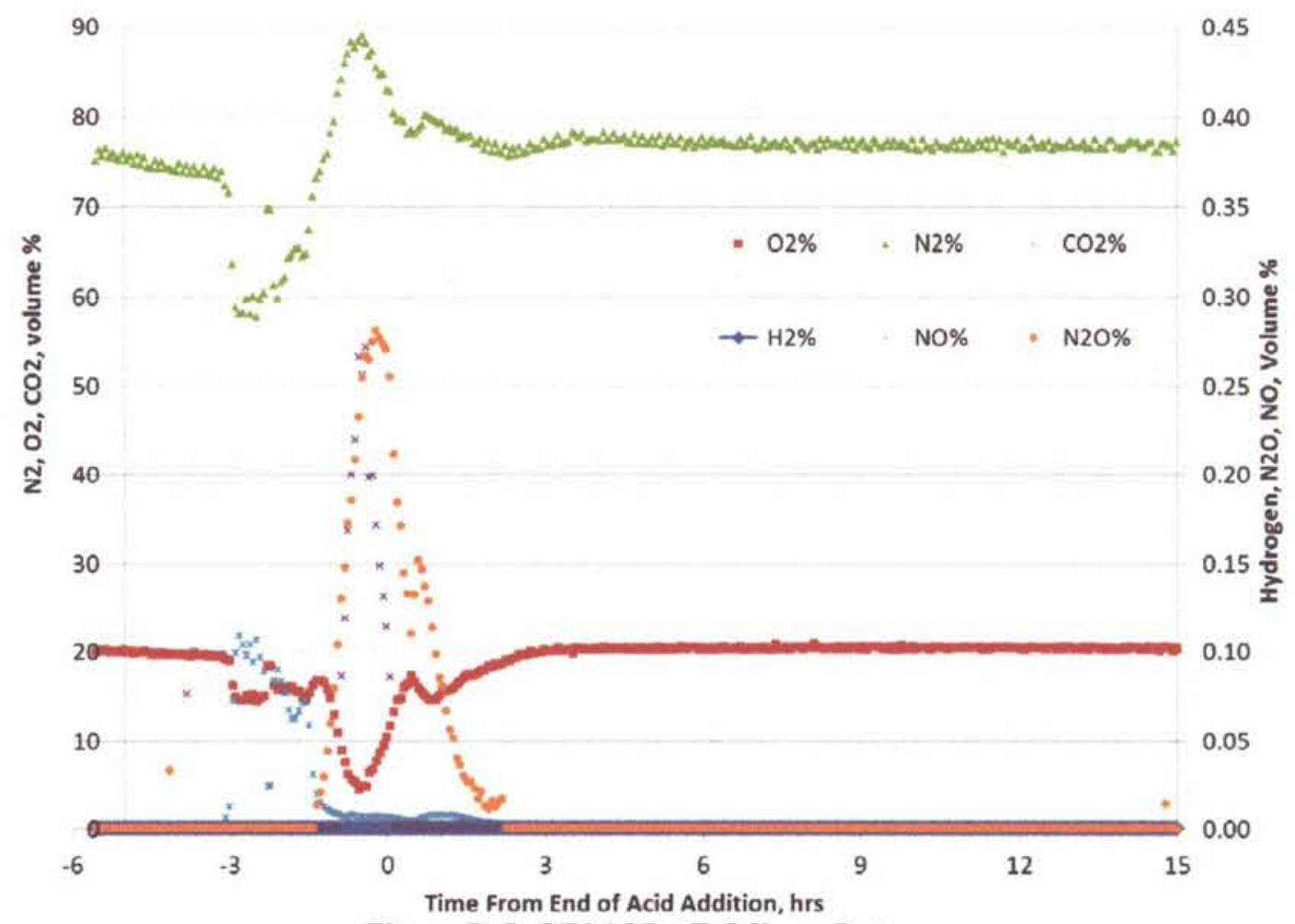

Figure B-5. GF36 SRAT Off-gas Data

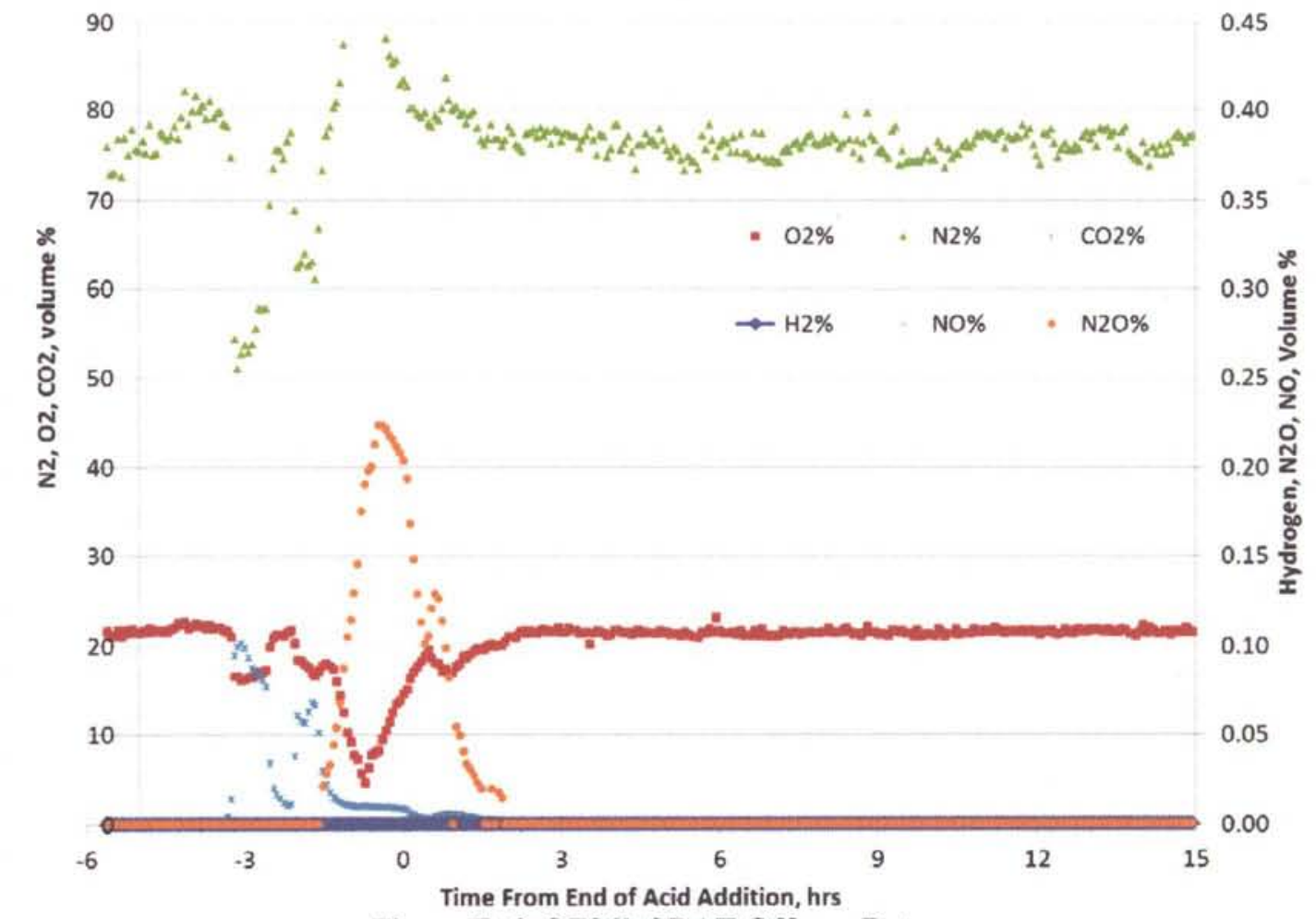

Figure B-6. GF36b SRAT Off-gas Data 
SRNL-STI-2012-00018

Revision 1

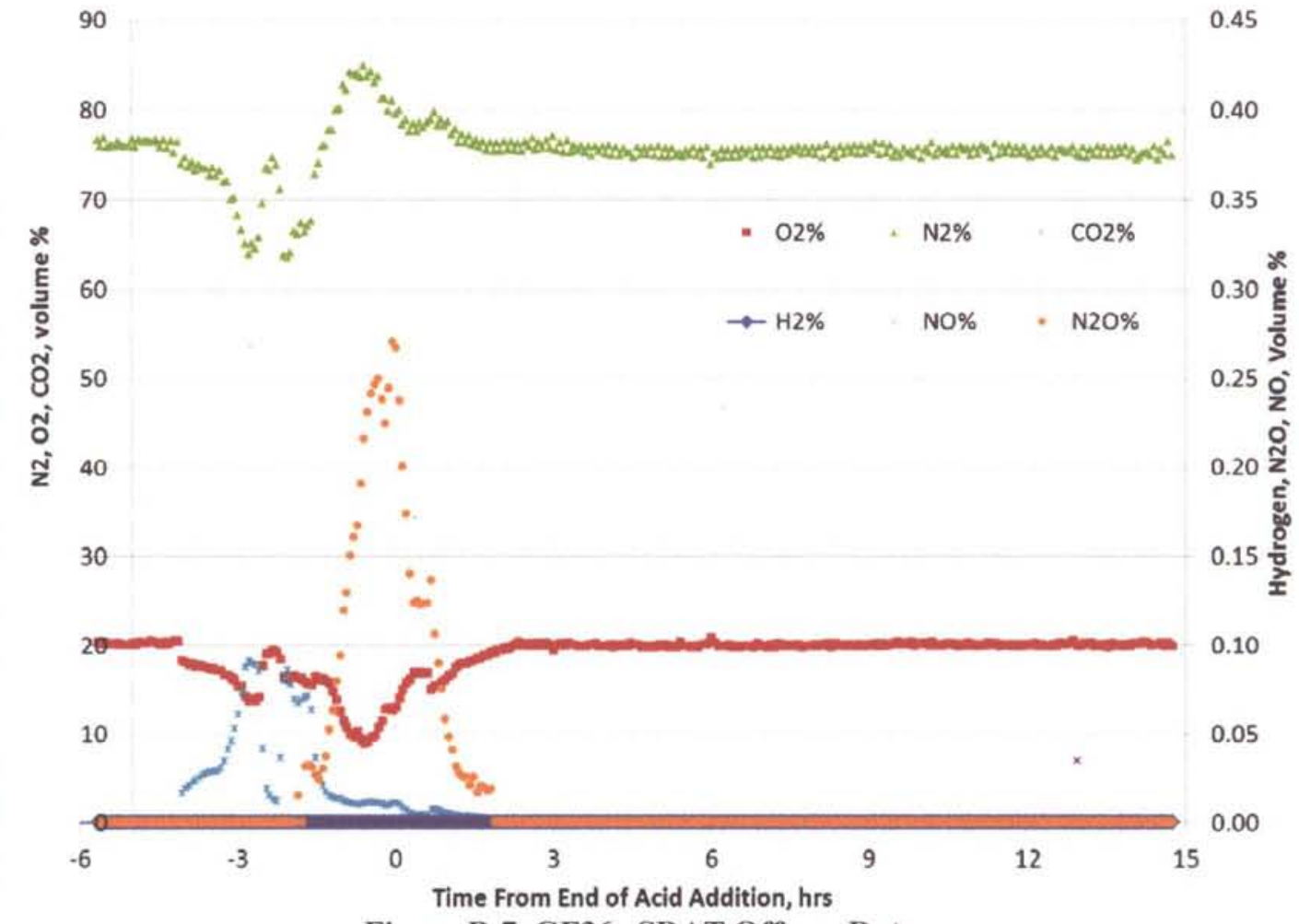

Figure B-7. GF36c SRAT Off-gas Data

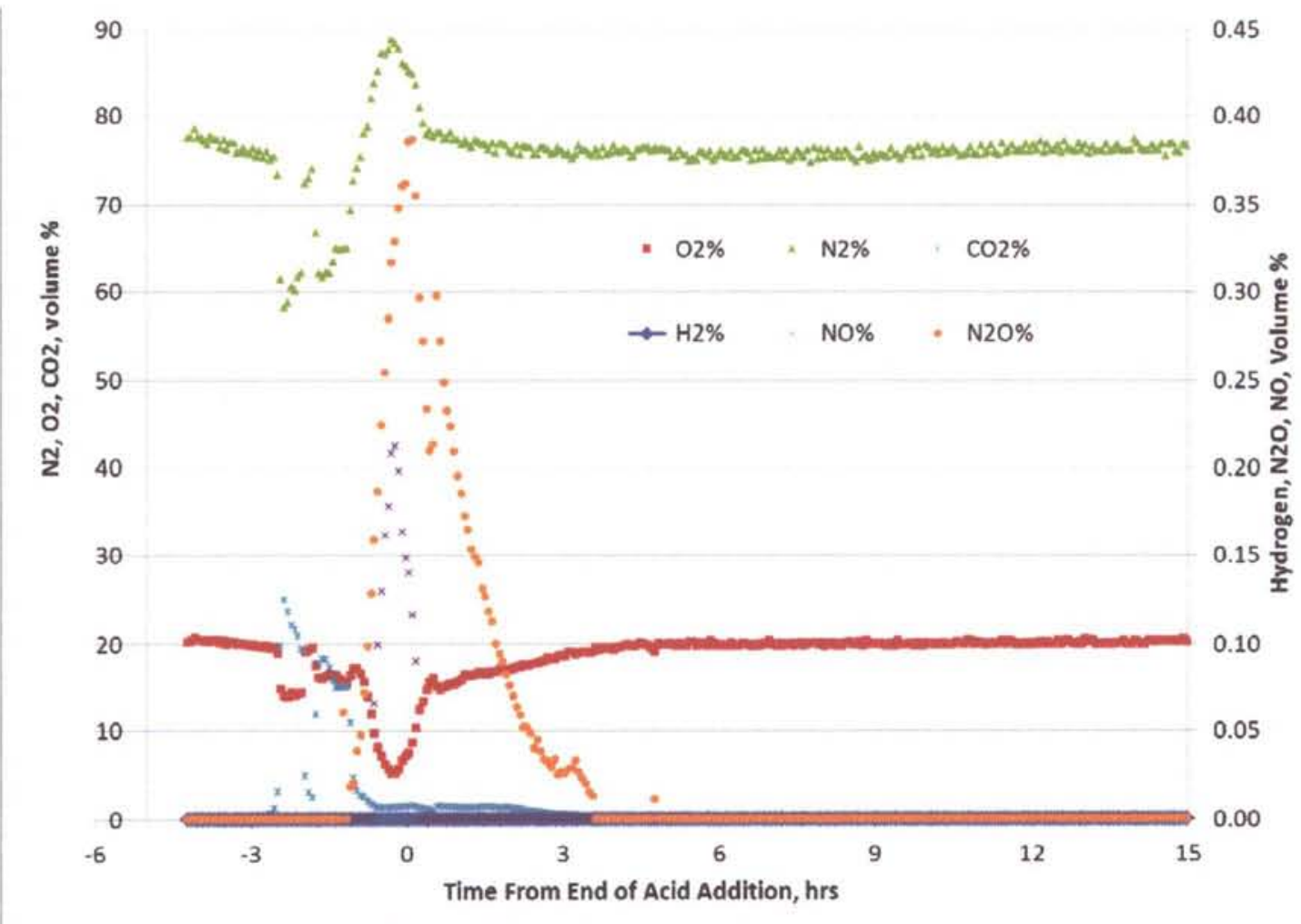

Figure B-8. GF37 SRAT Off-gas Data

B-5 
SRNL-STI-2012-00018

Revision 1



Figure B-9. GF37b SRAT Off-gas Data

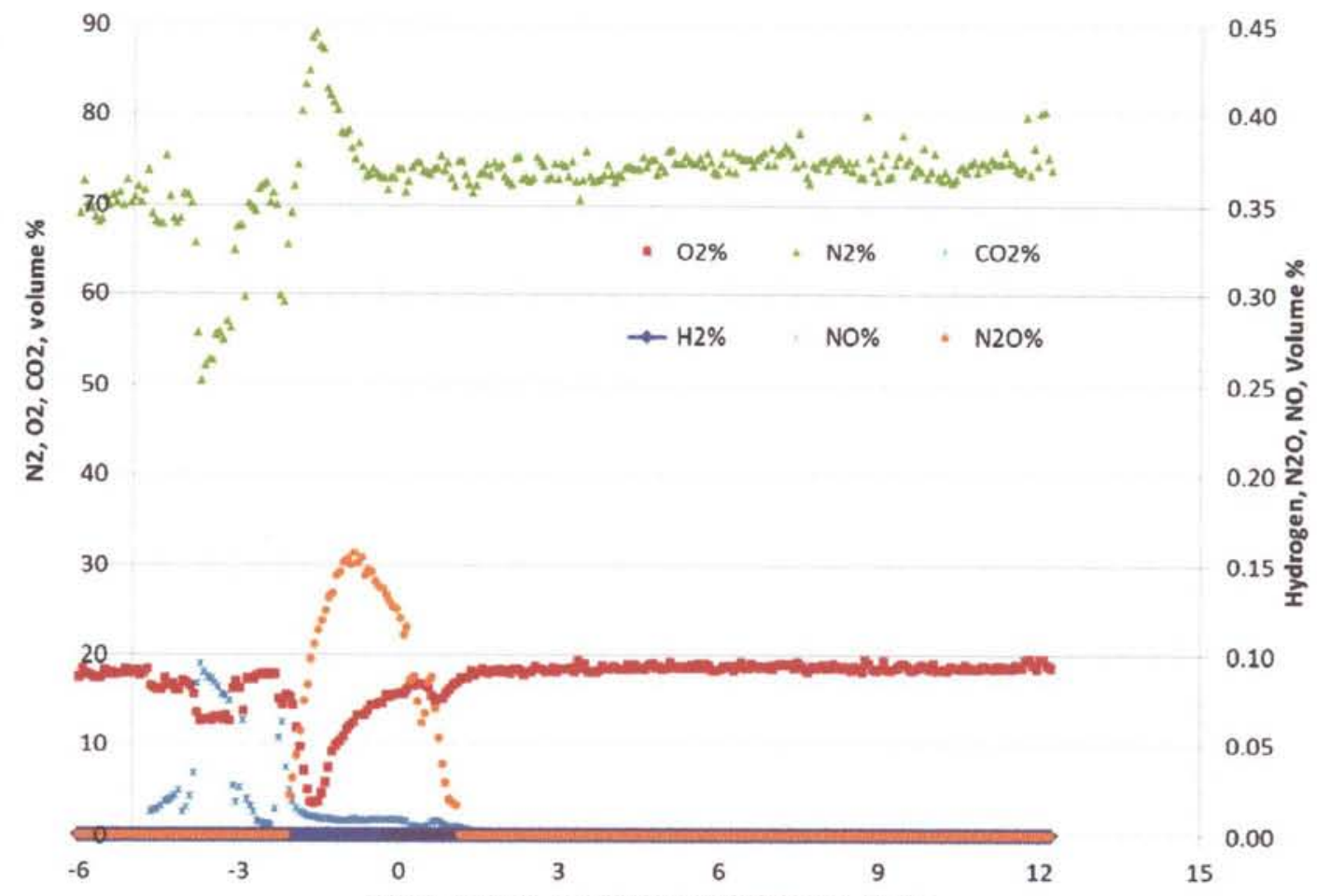

Figure B-10. GF38 SRAT Off-gas Data 
Revision 1

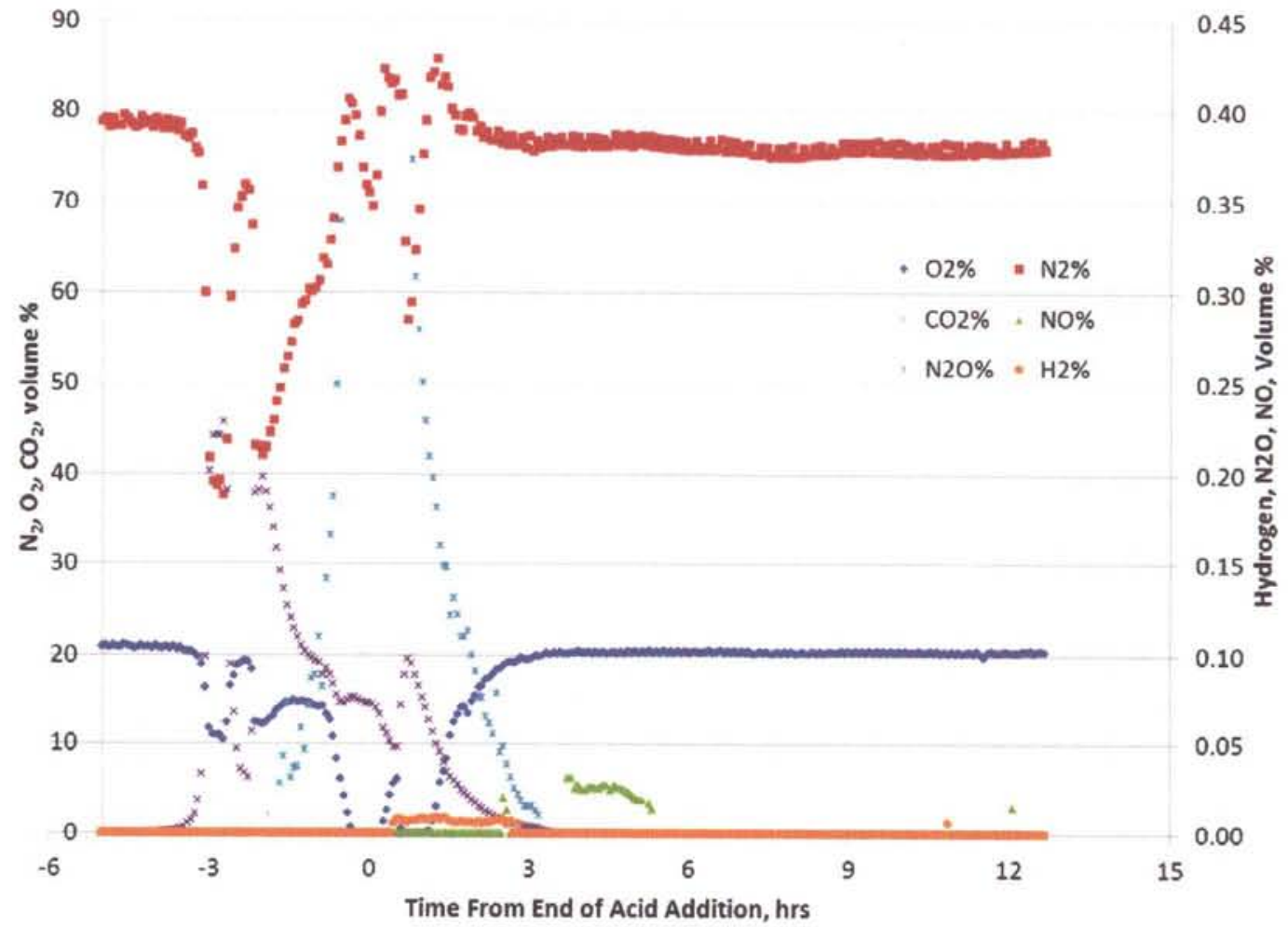

Figure B-11. GF40 SRAT Off-gas Data

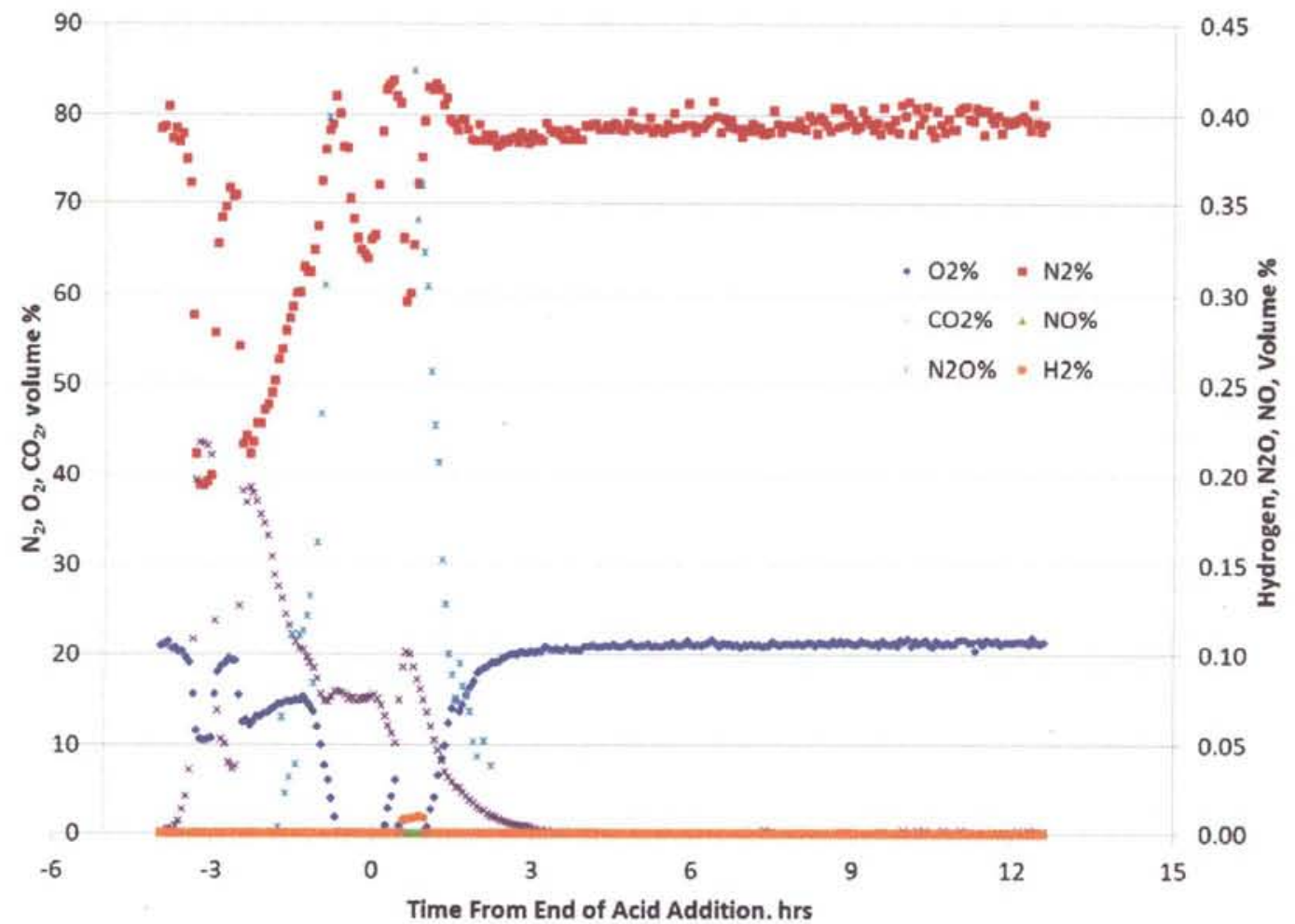

Figure B-12. GF41 SRAT Off-gas Data

B-7 
SRNL-STI-2012-00018

Revision 1

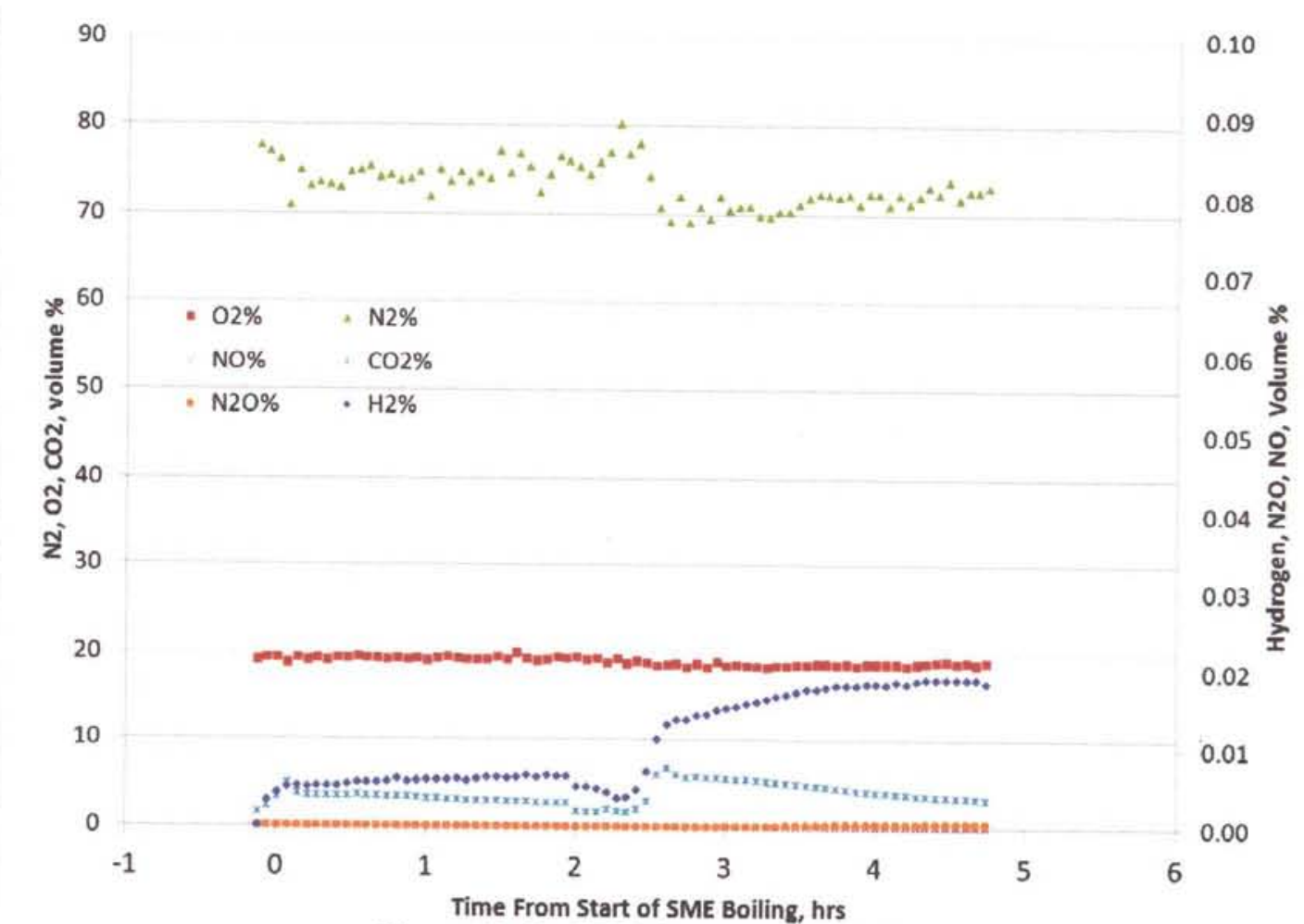

Figure B-13. GF34 SME Off-gas Data

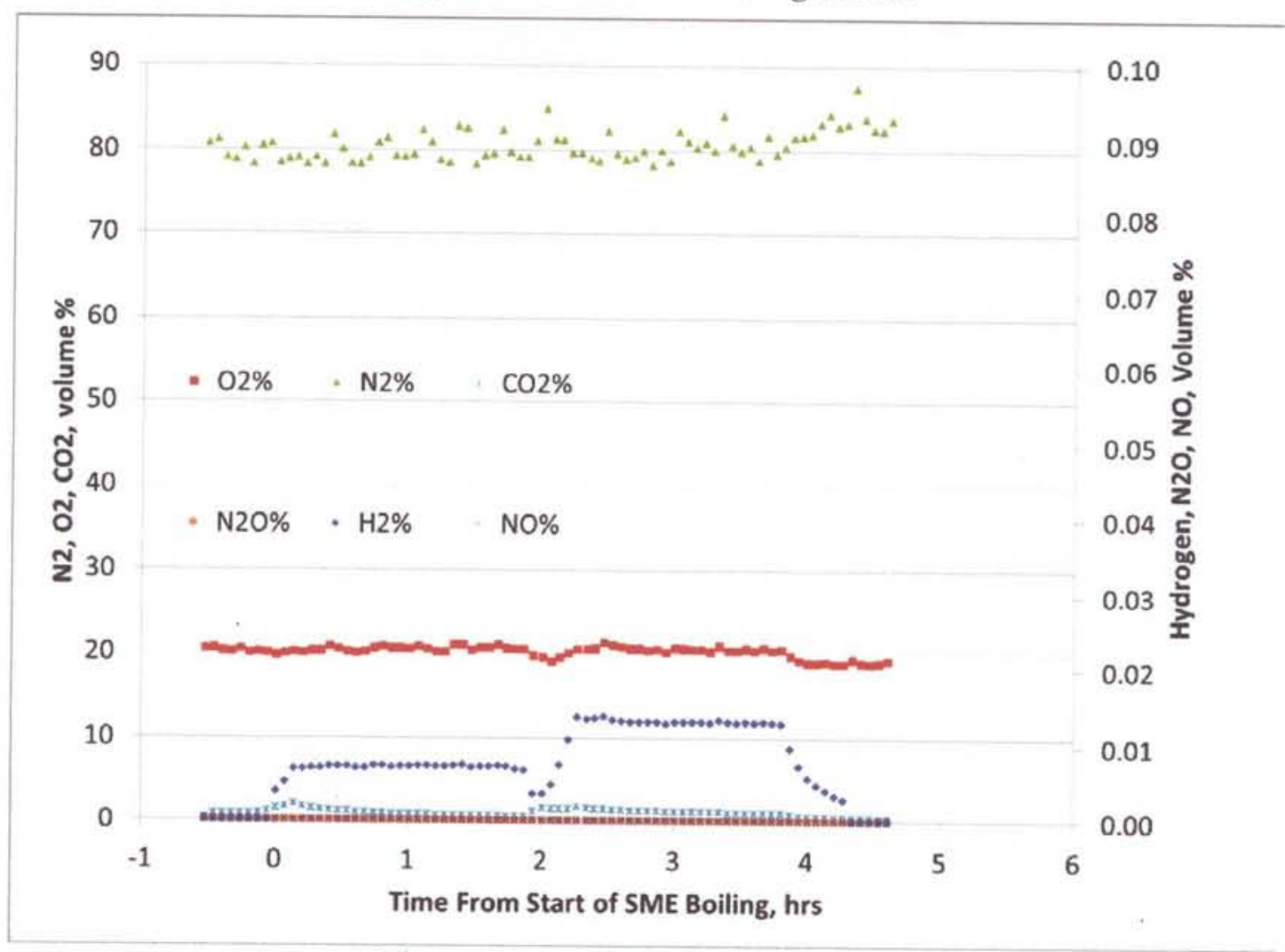

Figure B-14. GF35 SME Off-gas Data

B-8 
Revision 1

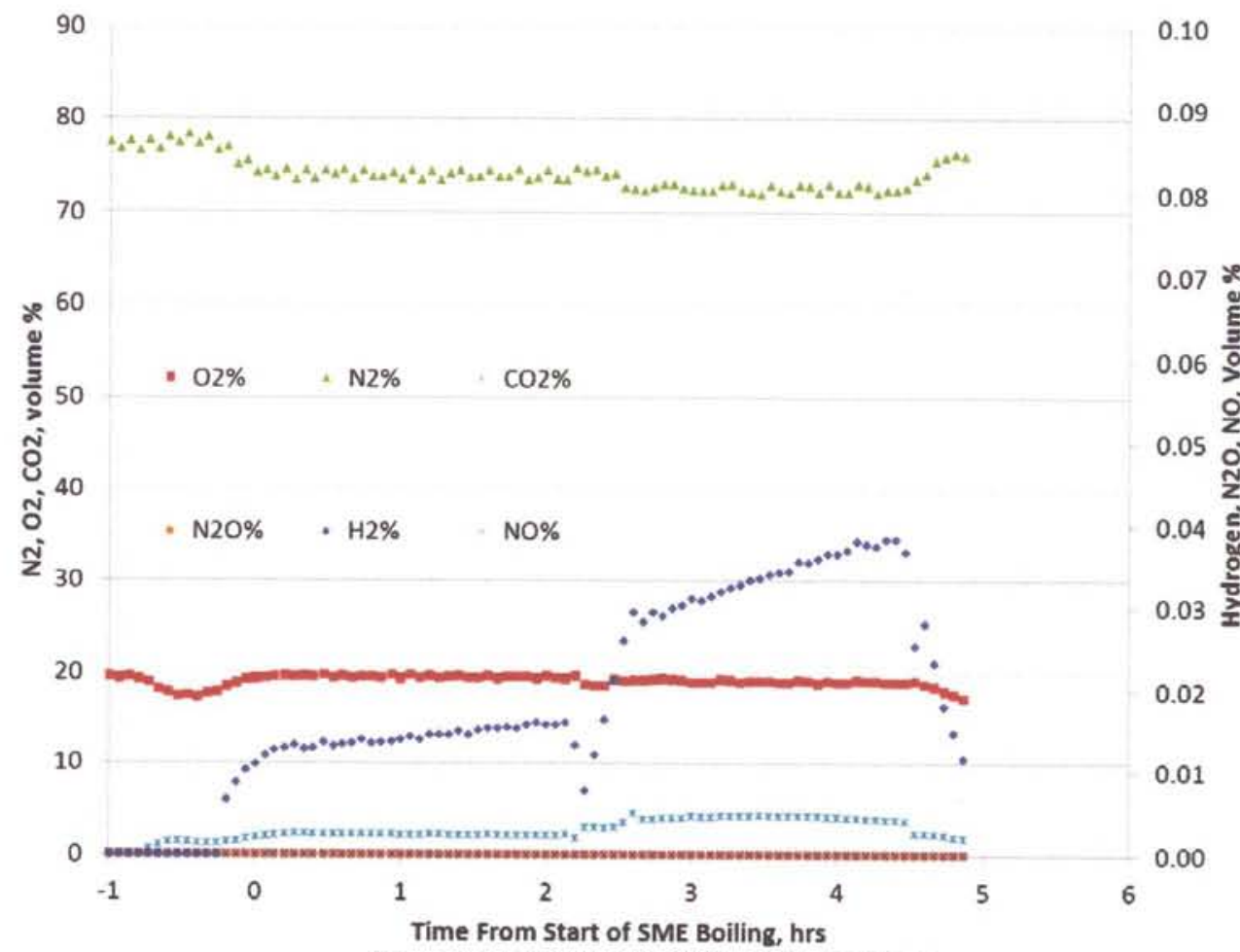

Figure B-15. GF36 SME Off-gas Data

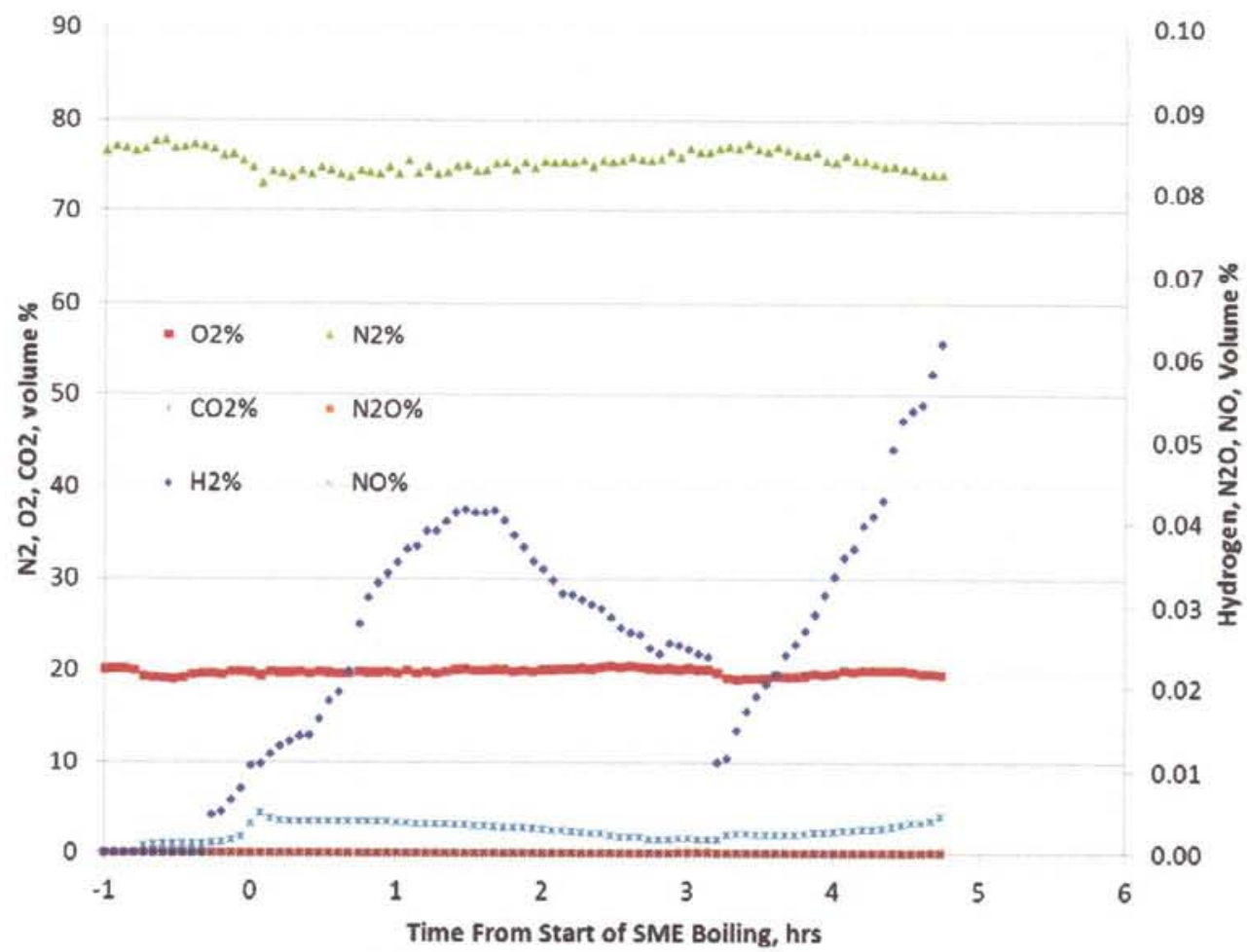

Figure B-16. GF37 SME Off-gas Data 


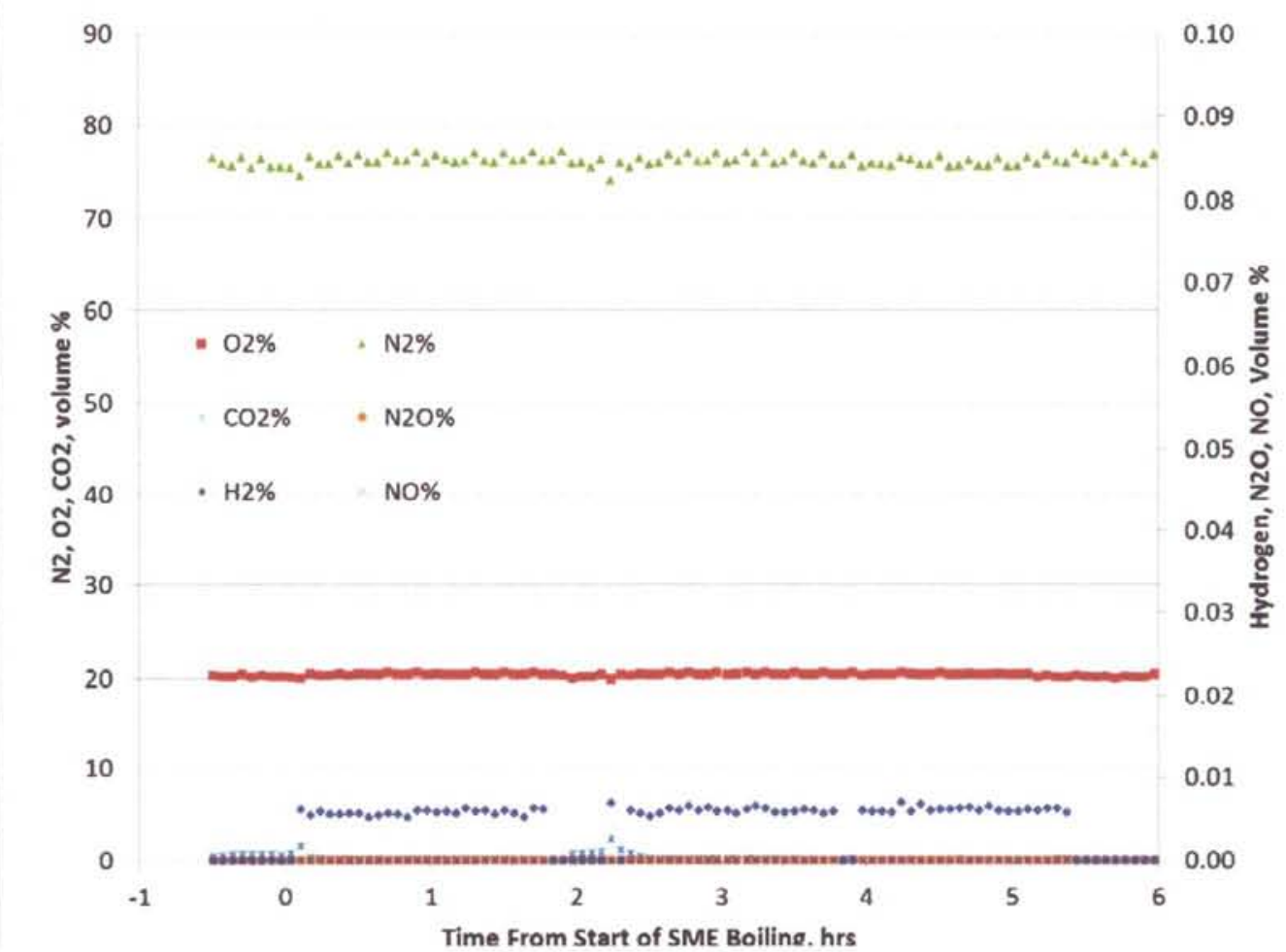

Figure B-17. GF40 SME Off-gas Data

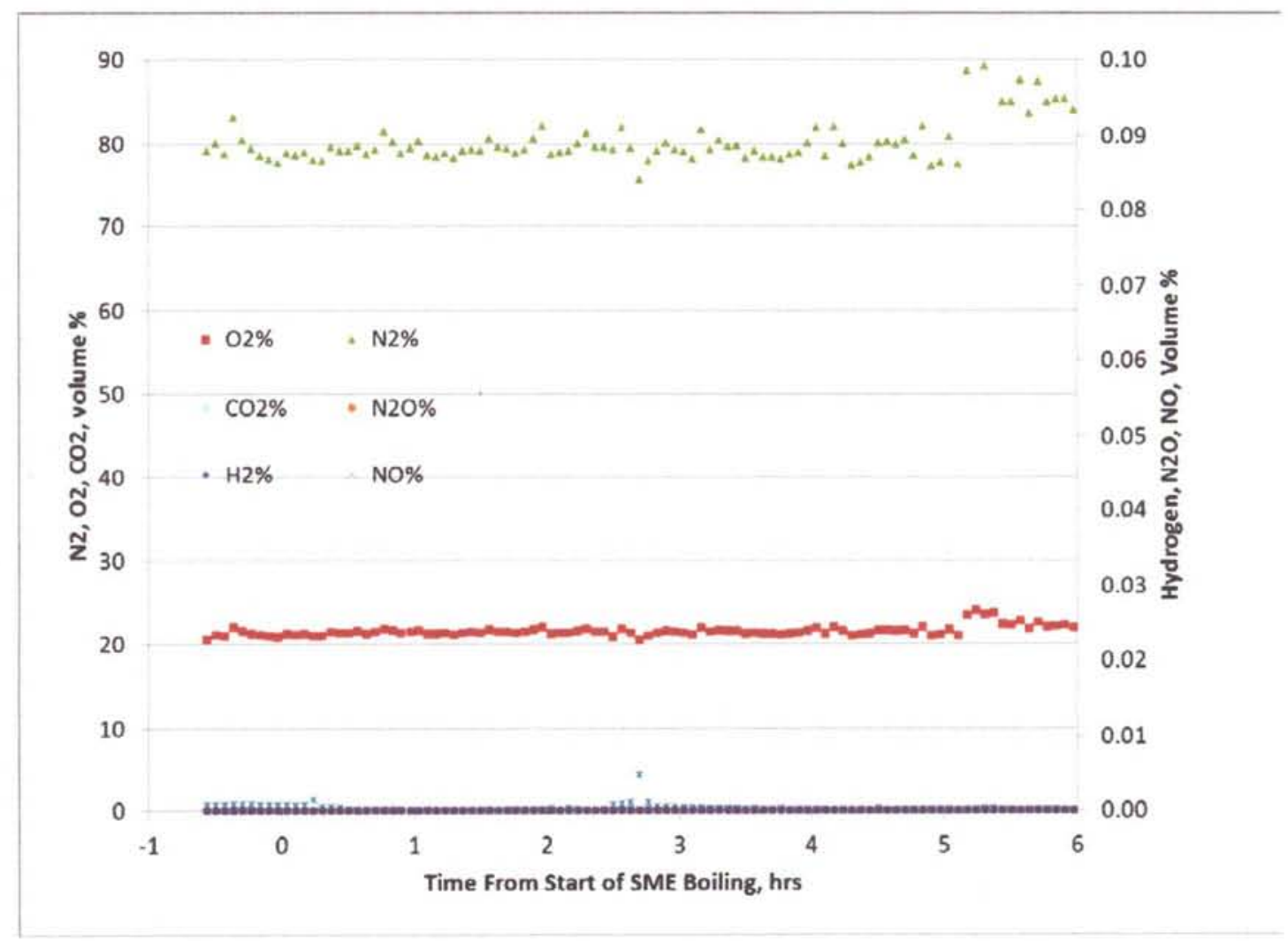

Figure B-18. GF41 SME Off-gas Data

B-10 
SRNL-STI-2012-00018

Revision 1

Appendix C. X-ray Defraction (XRD) Results of SRAT and SME Solids and Mercury Solids 
This Appendix contains X-ray diffraction data for samples of the crystallized solids that formed post cooling in some SRAT and SME products from the matrix runs.

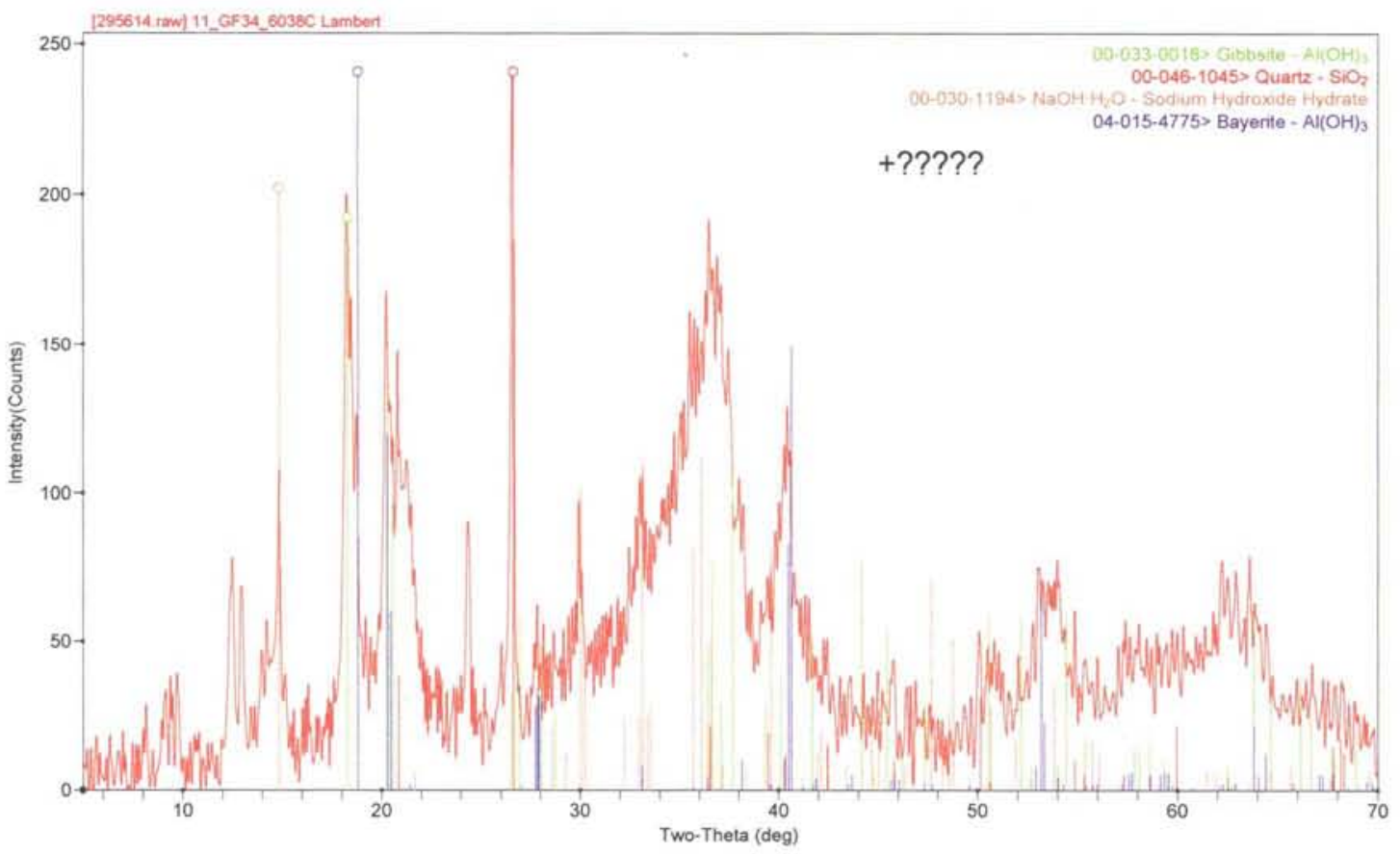

${ }^{*}$ The $\mathrm{NaOH}^{*} \mathrm{H} 2 \mathrm{O}$ is questionable. There is a phase in this sample that could not be identified.

Figure C-1. GF34 SRAT Product

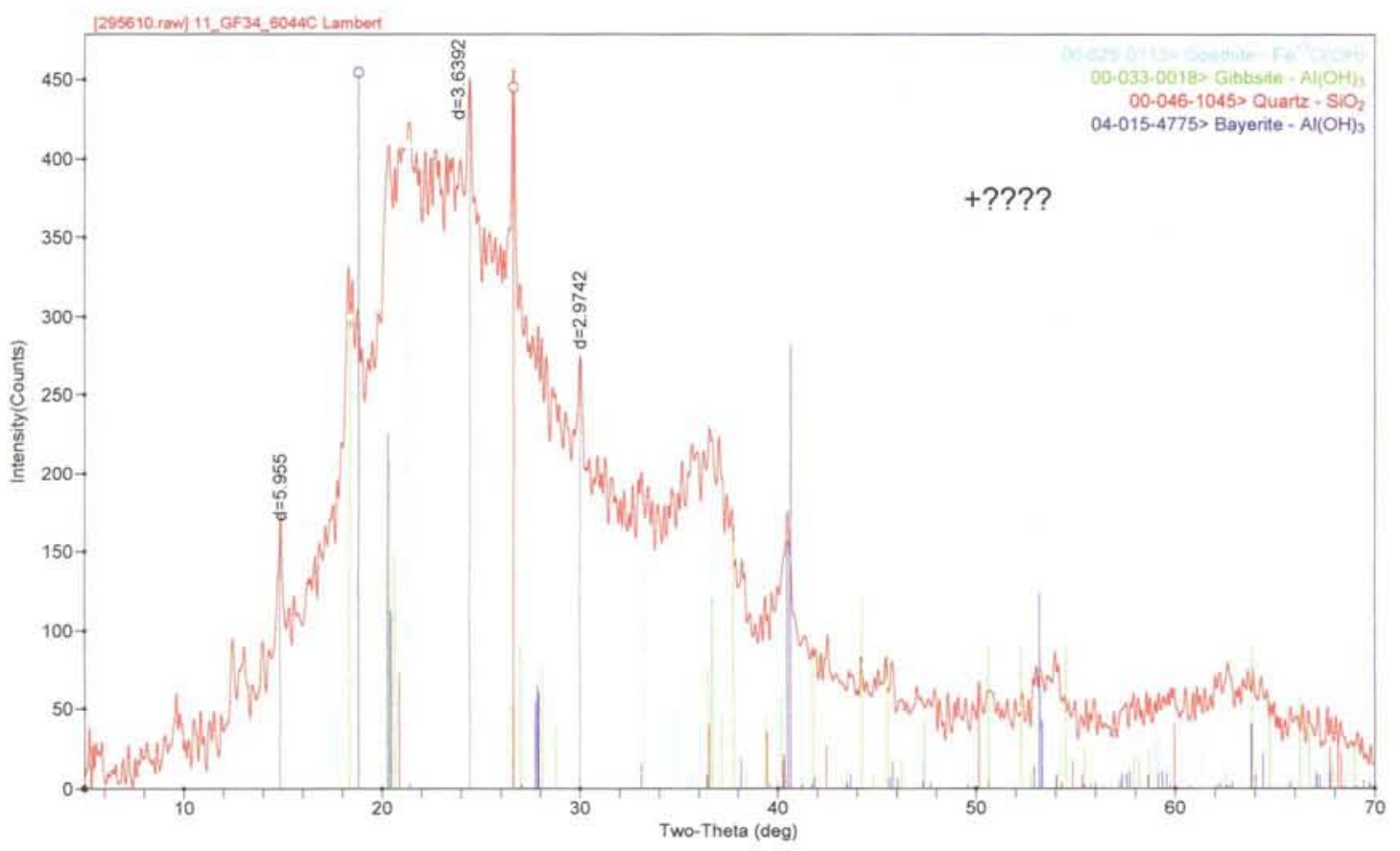


Figure C-2. GF34 SME Product XRD

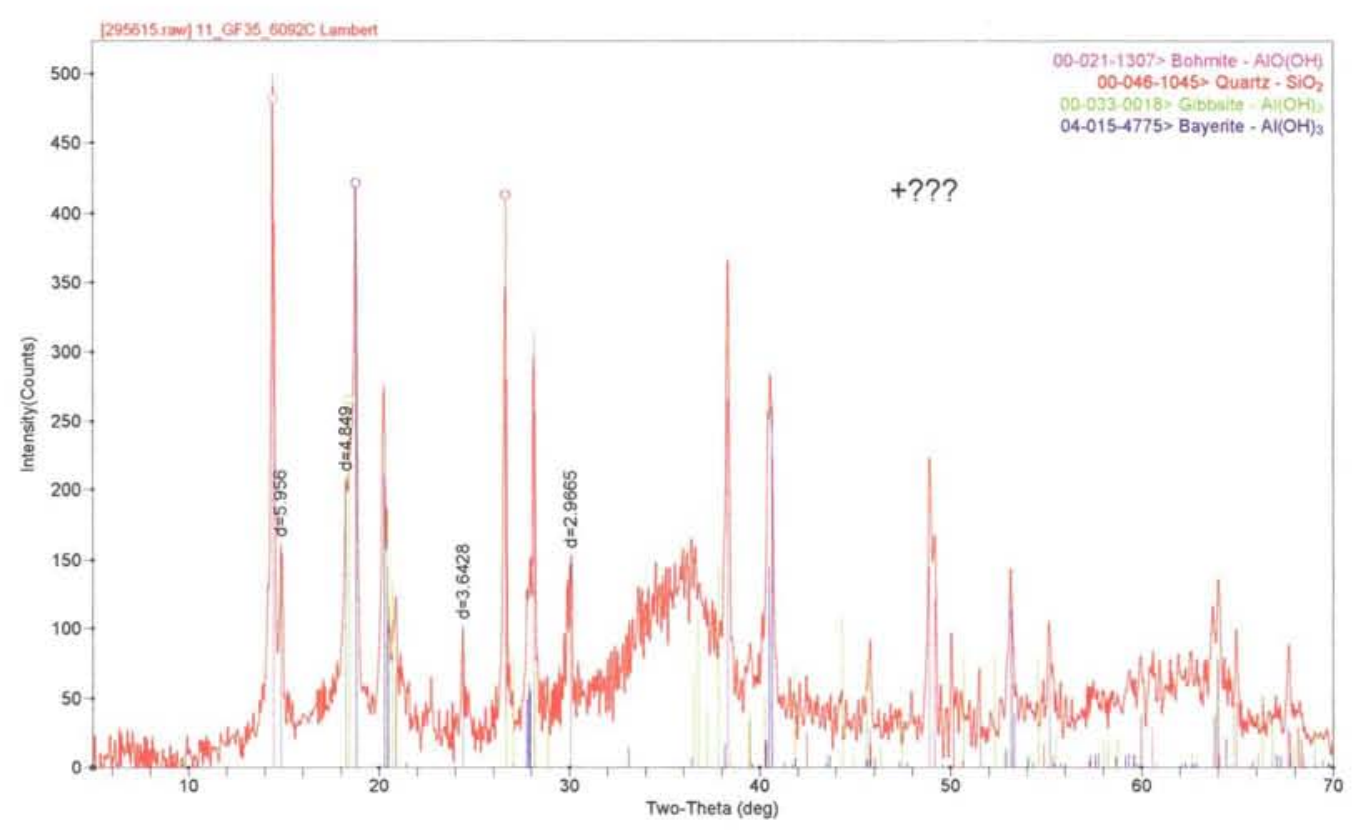

Figure C-3. GF35 SRAT Product XRD

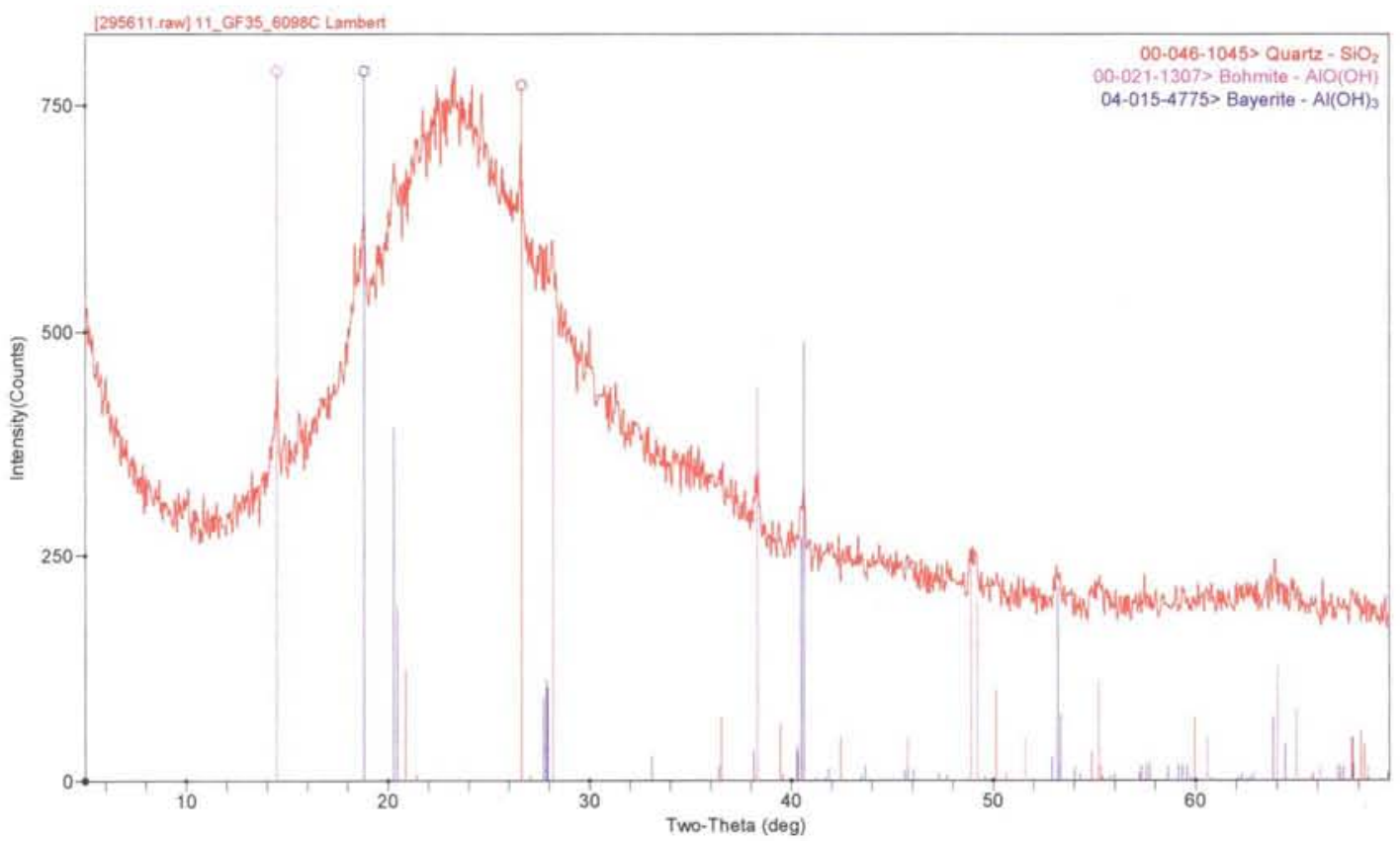

Figure C-4. GF35 SME Product 
SRNL-STI-2012-00018

Revision 1

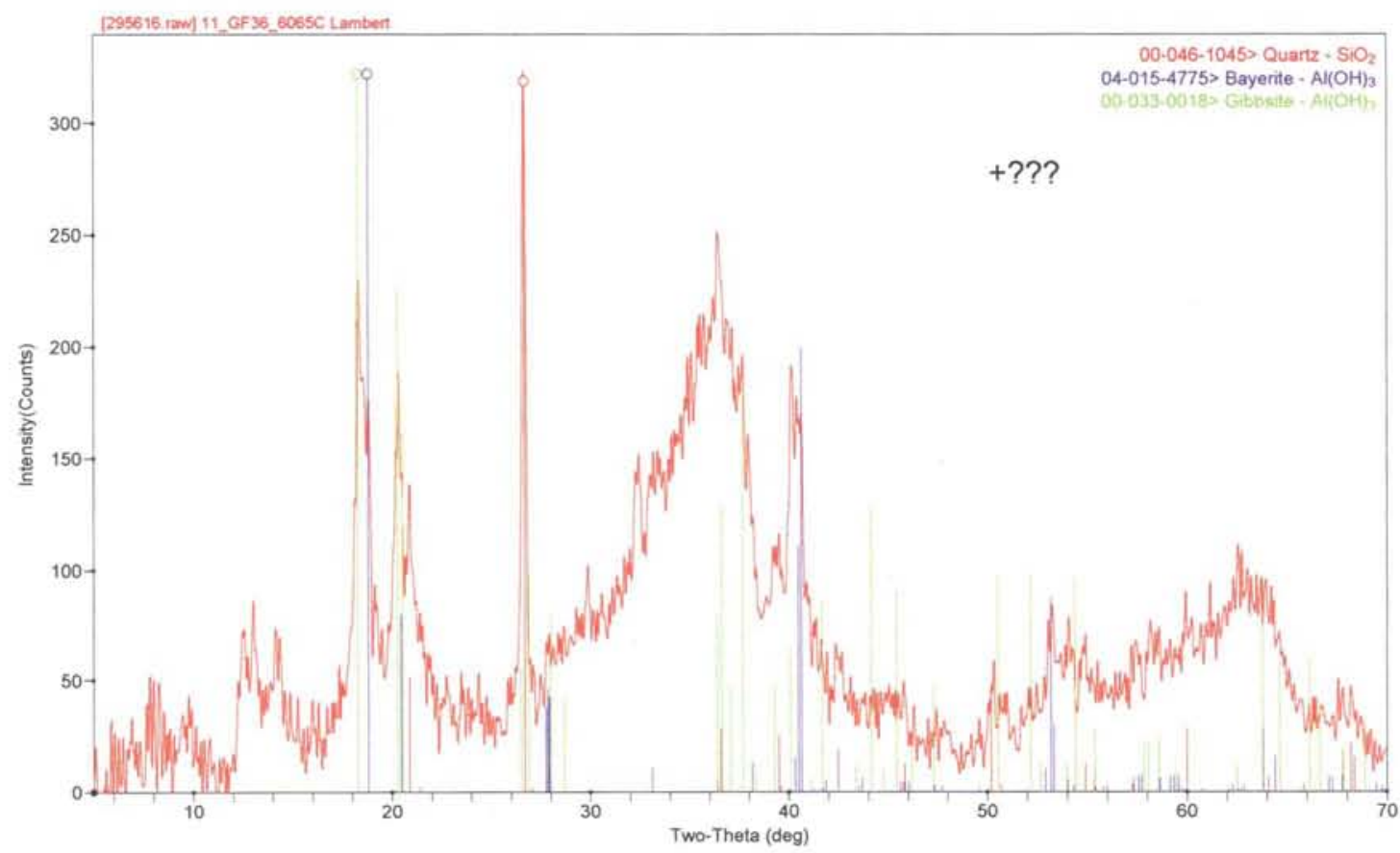

Figure C-5. GF36 SRAT Product

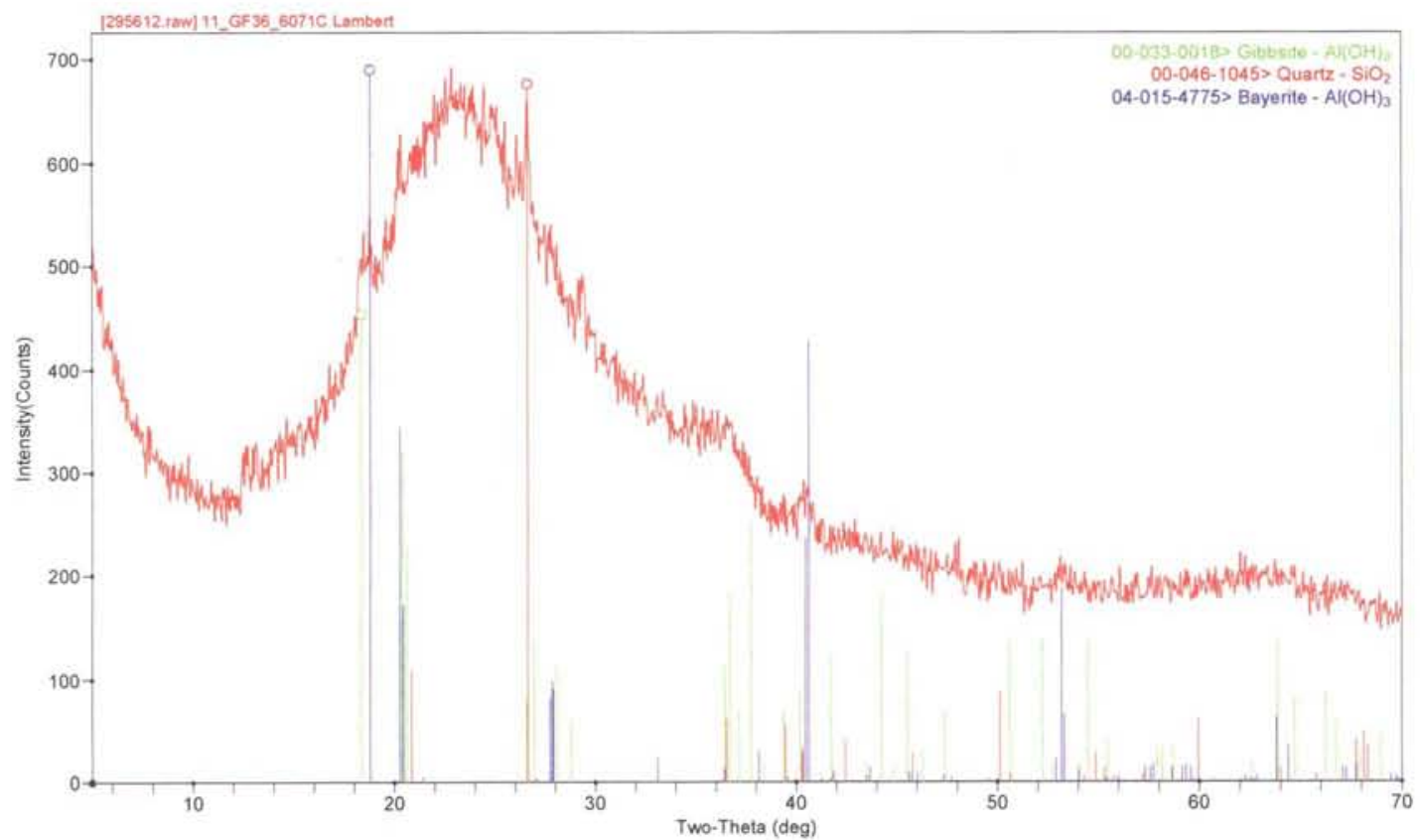

Figure C-6. GF36 SME Product

C-4 
SRNL-STI-2012-00018

Revision 1

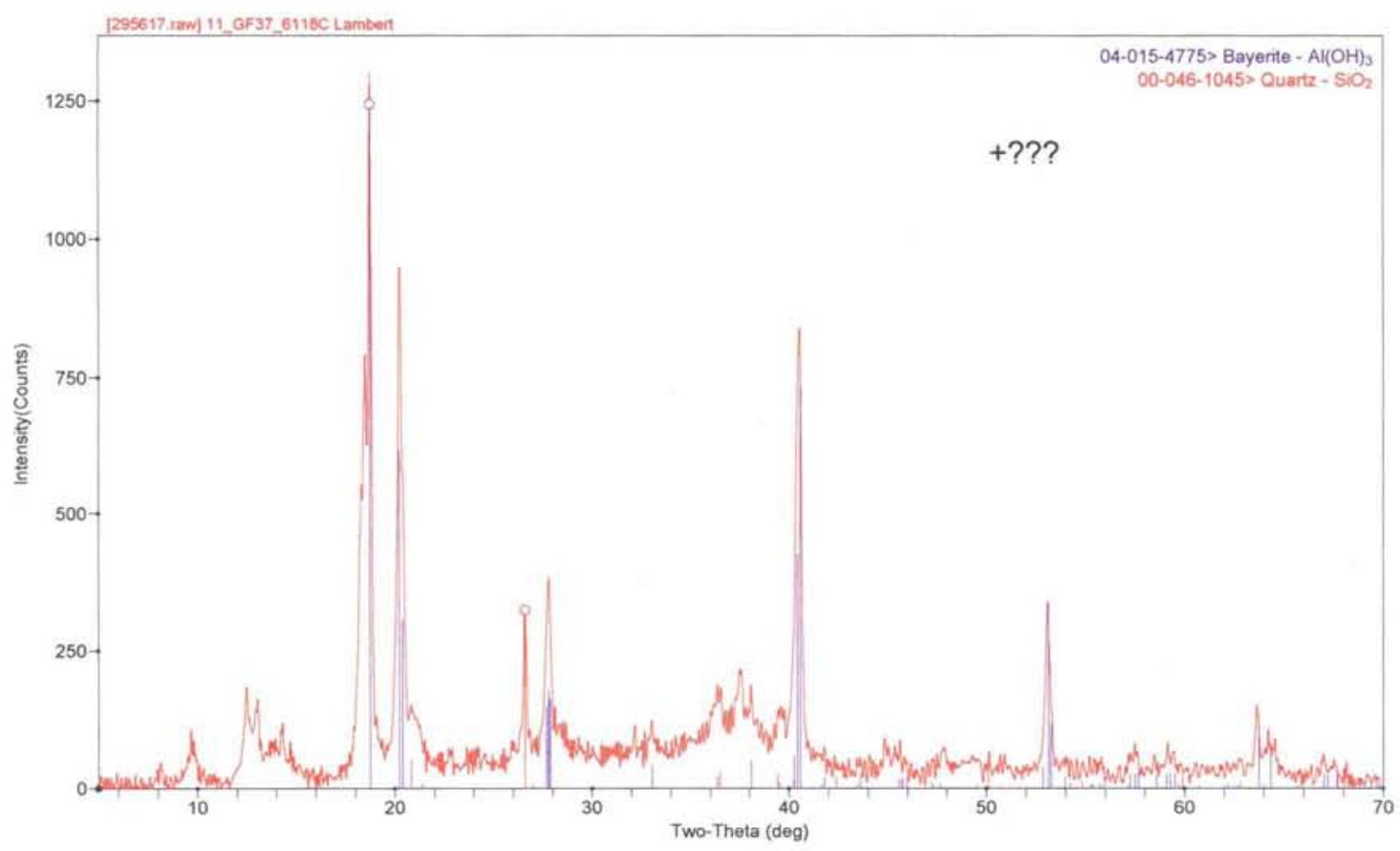

Figure C-7. GF37 SRAT Product

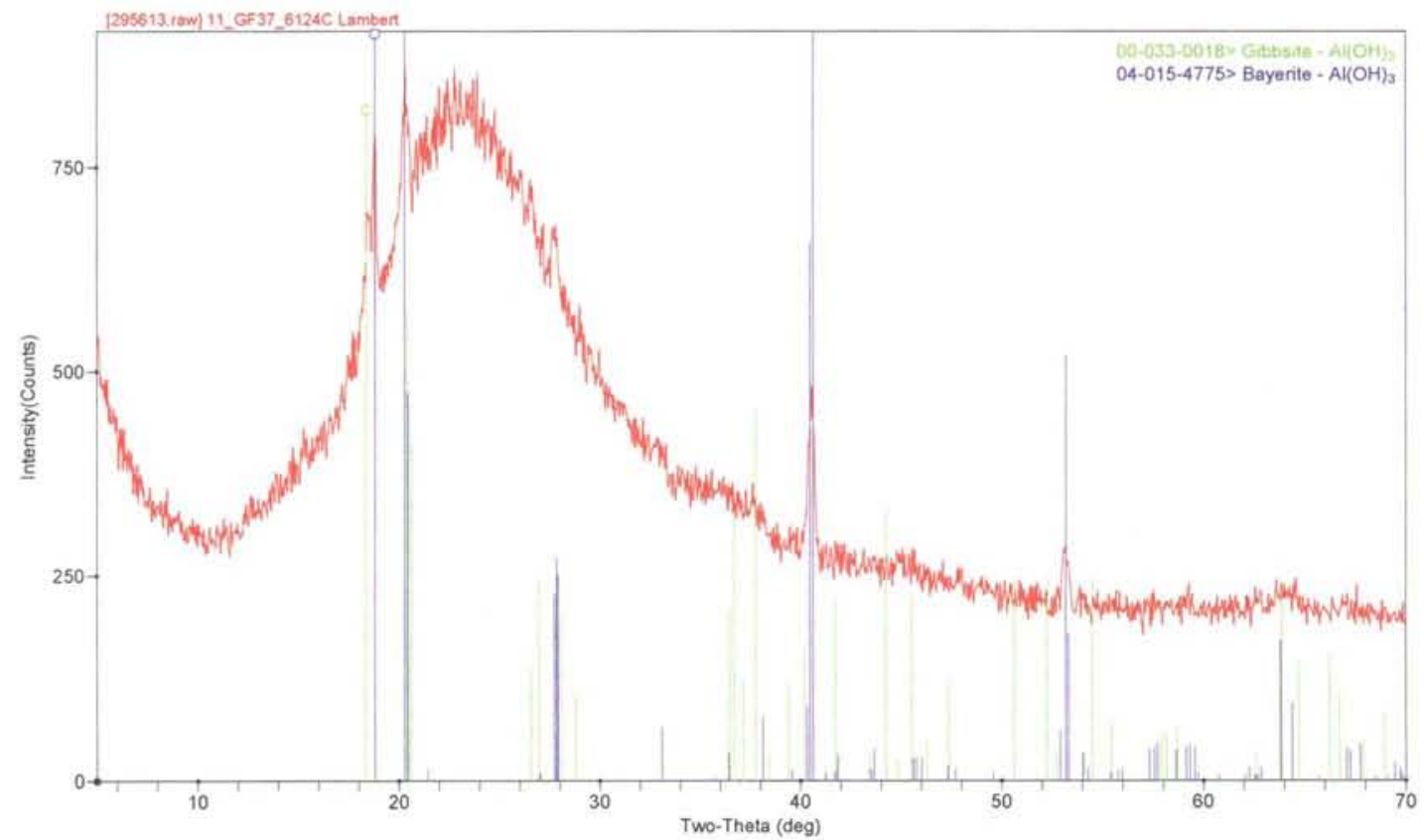

Figure C-8. GF37 SME Product 
SRNL-STI-2012-00018

Revision 1

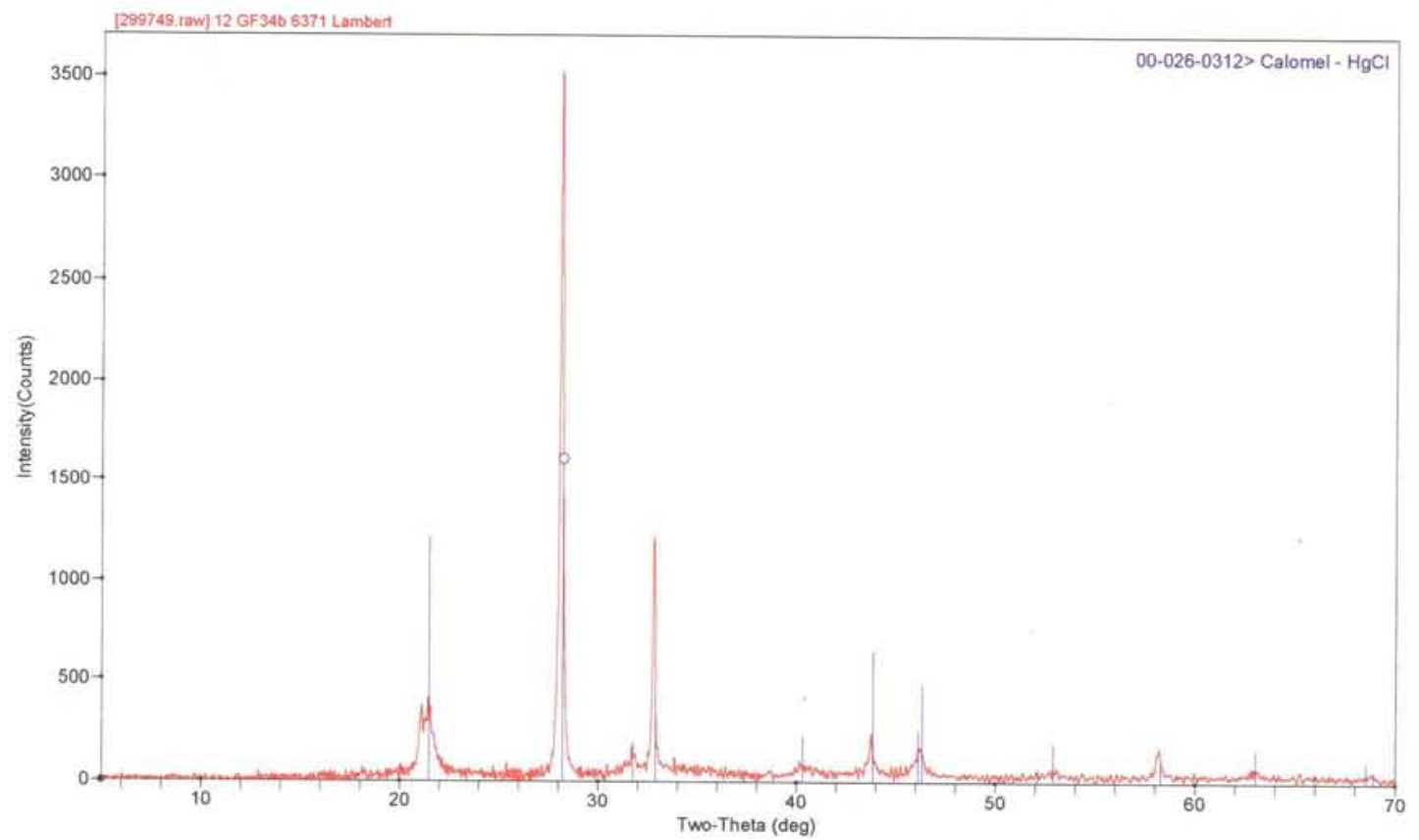

Figure C-9. GF34b MWWT Mercury Product

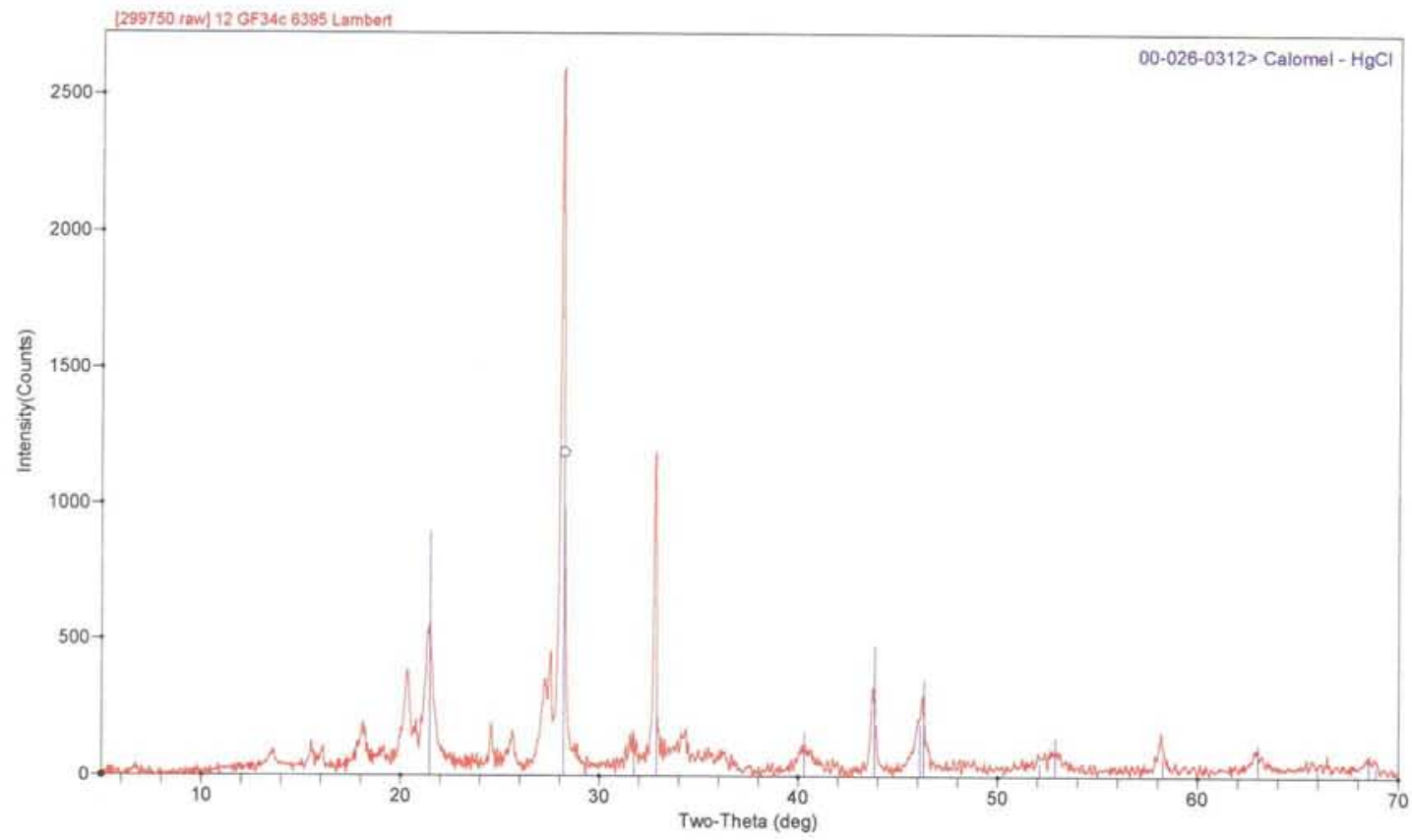

Figure C-10. GF34c MWWT Mercury Product 
SRNL-STI-2012-00018

Revision 1

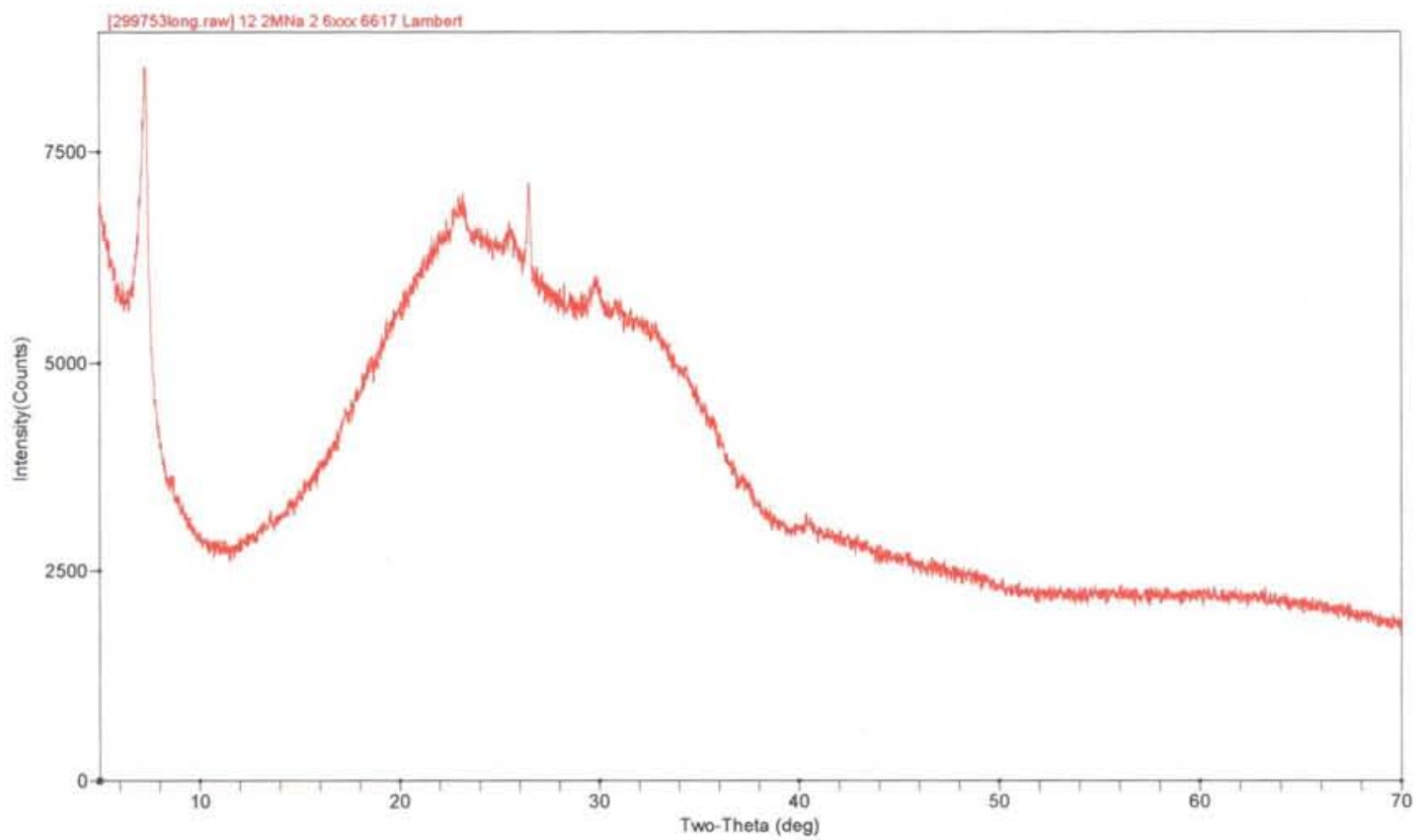

Figure C-11. GF40 MWWT Mercury Product

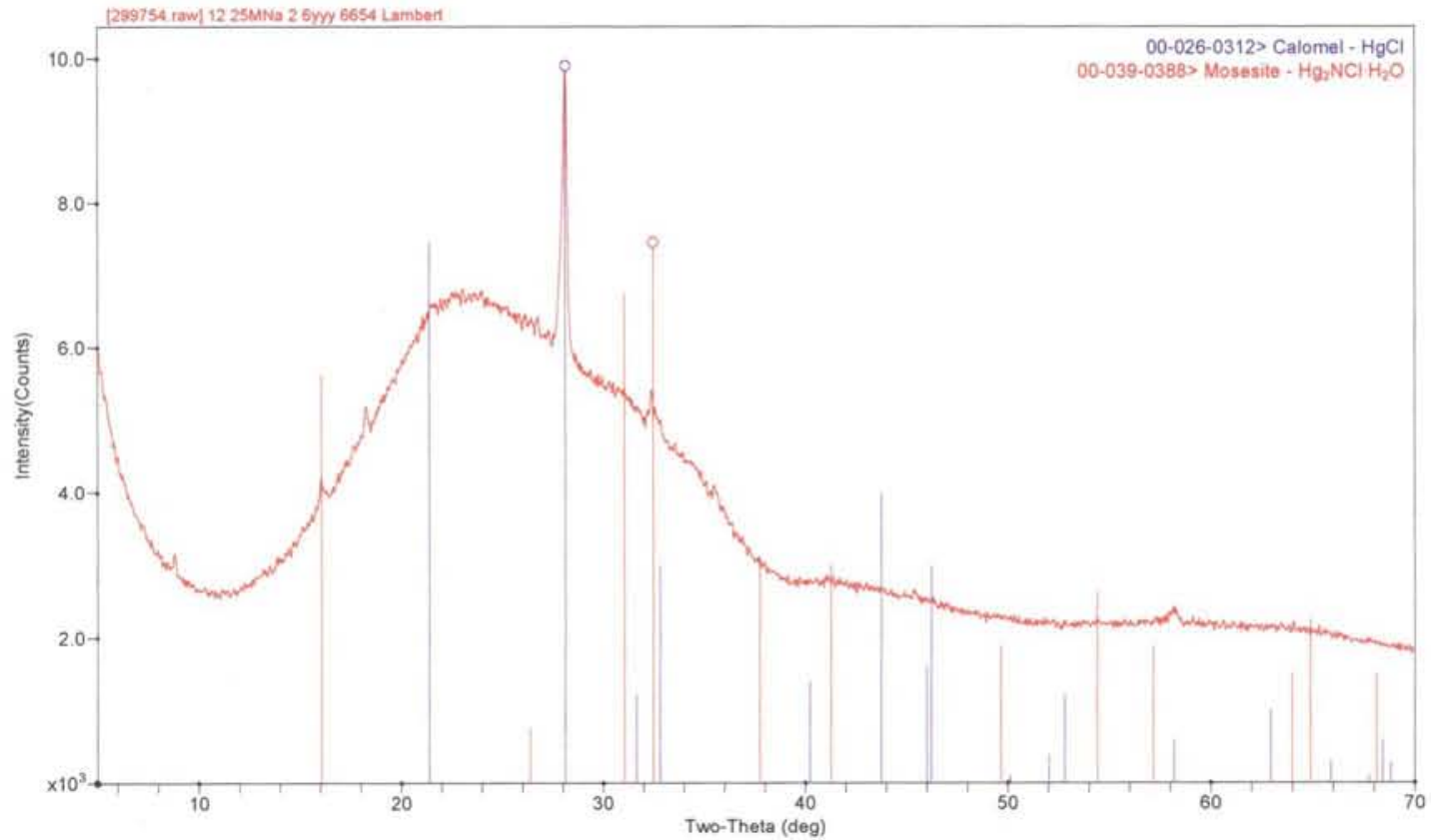

Figure C-12. GF41 MWWT Mercury Product 
SRNL-STI-2012-00018

Revision 1

Appendix D. Supernate Results 
This Appendix includes additional data collected from experiments using a supernate simulant instead of sludge as described in Section 3.1.

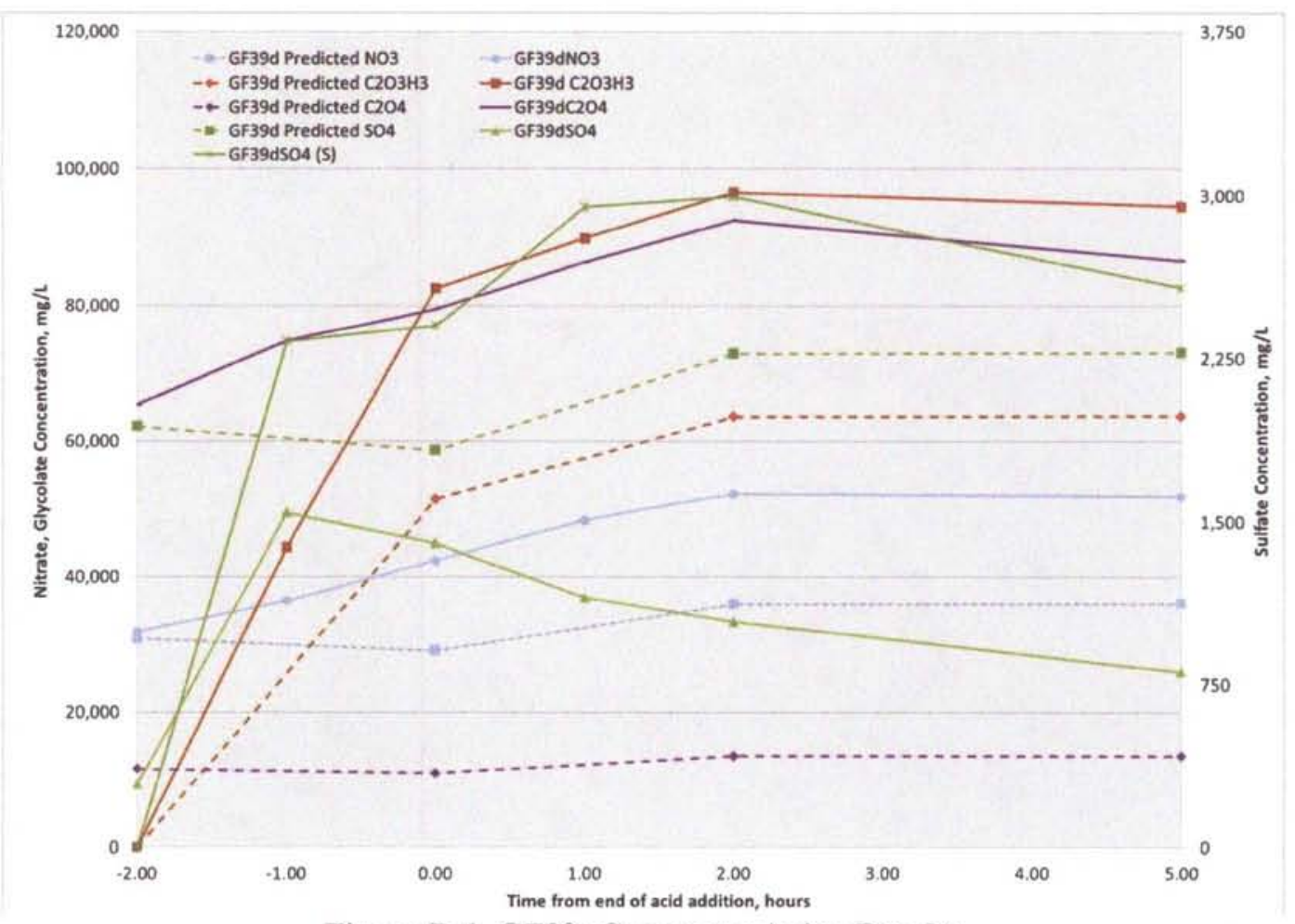

Figure D-1. GF39a Supernate Anion Results

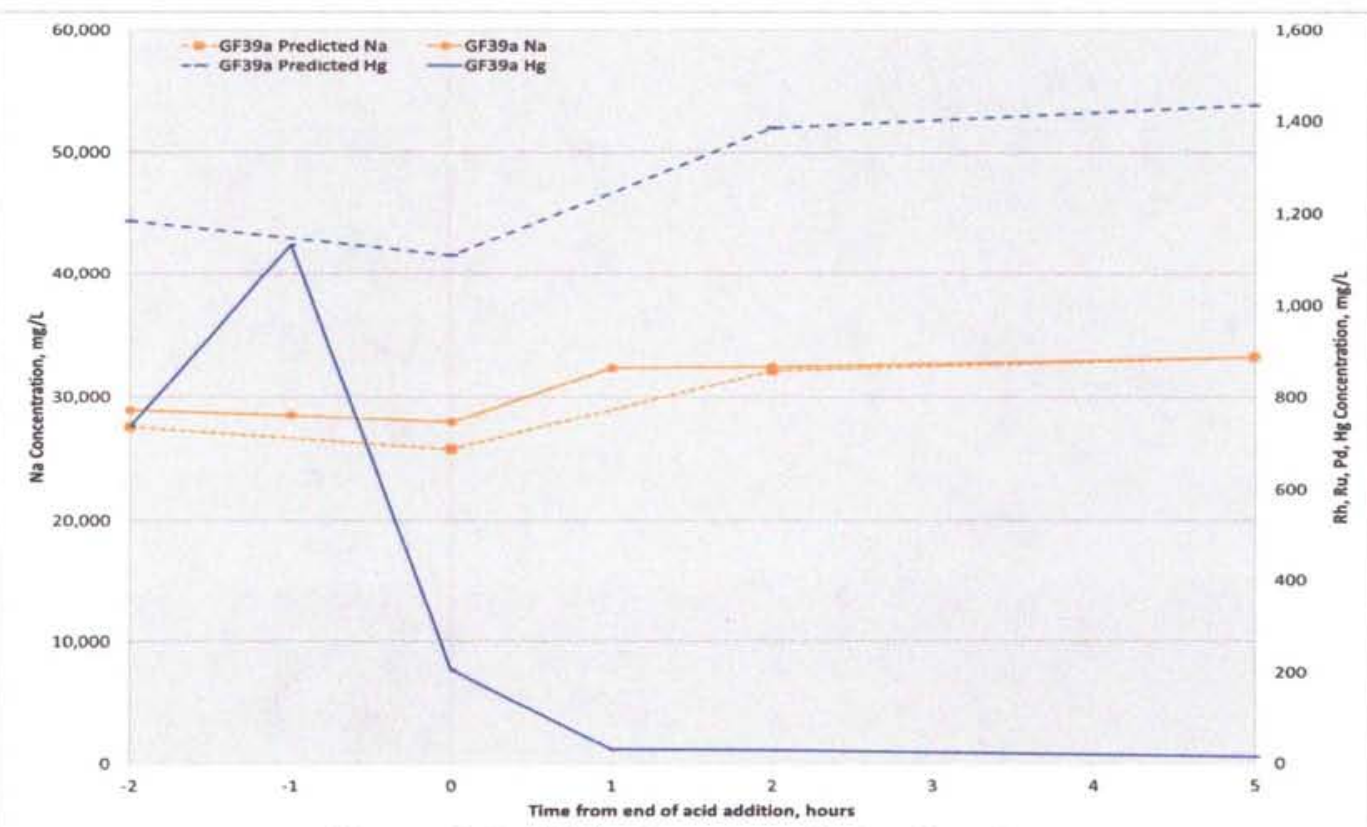

Figure D-2. GF39a Supernate Cation Results 
Revision 1

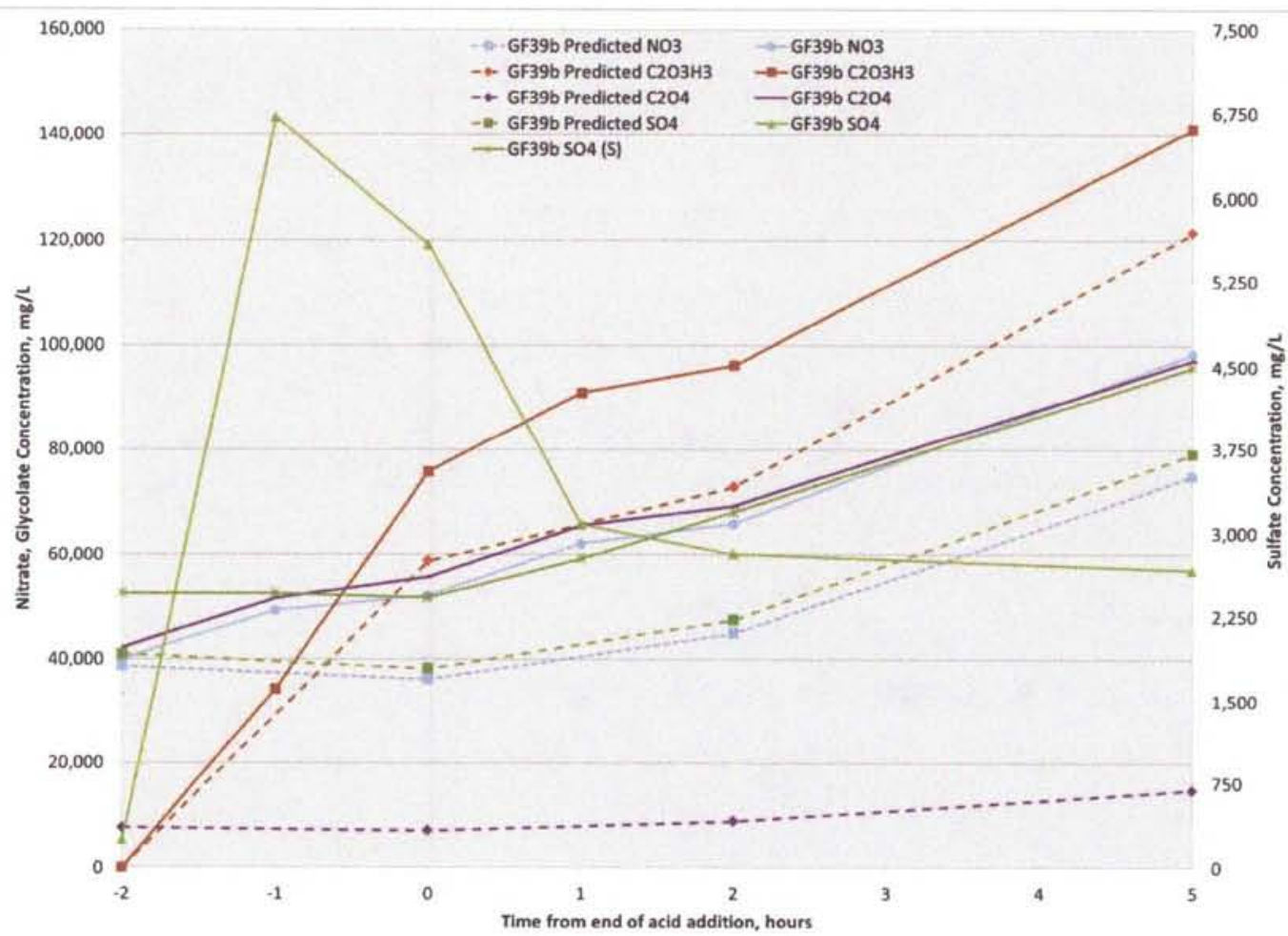

Figure D-3. GF39b Supernate Anion Results

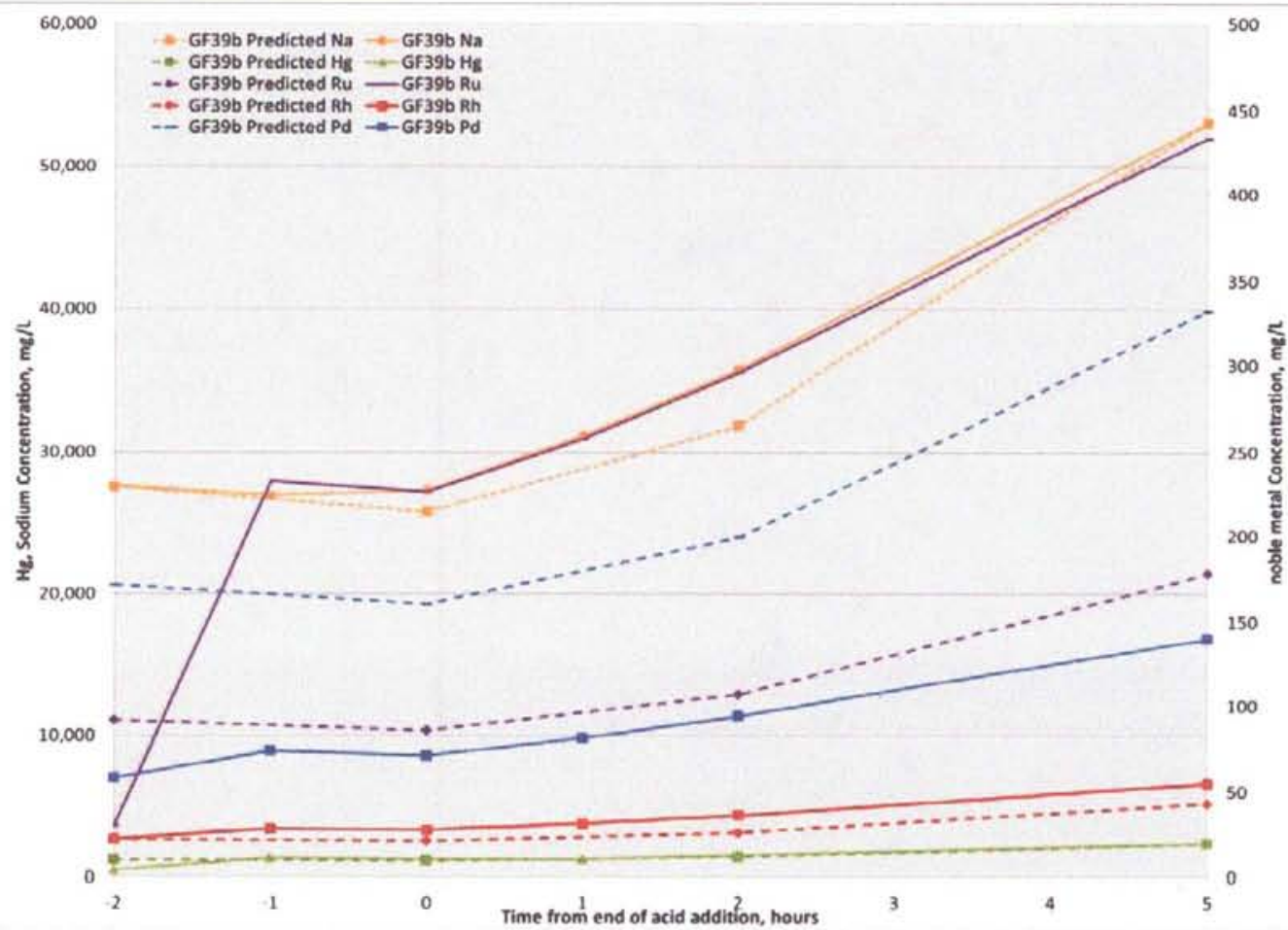

Figure D-4. GF39b Supernate Cation Results

D-3 
SRNL-STI-2012-00018

Revision 1

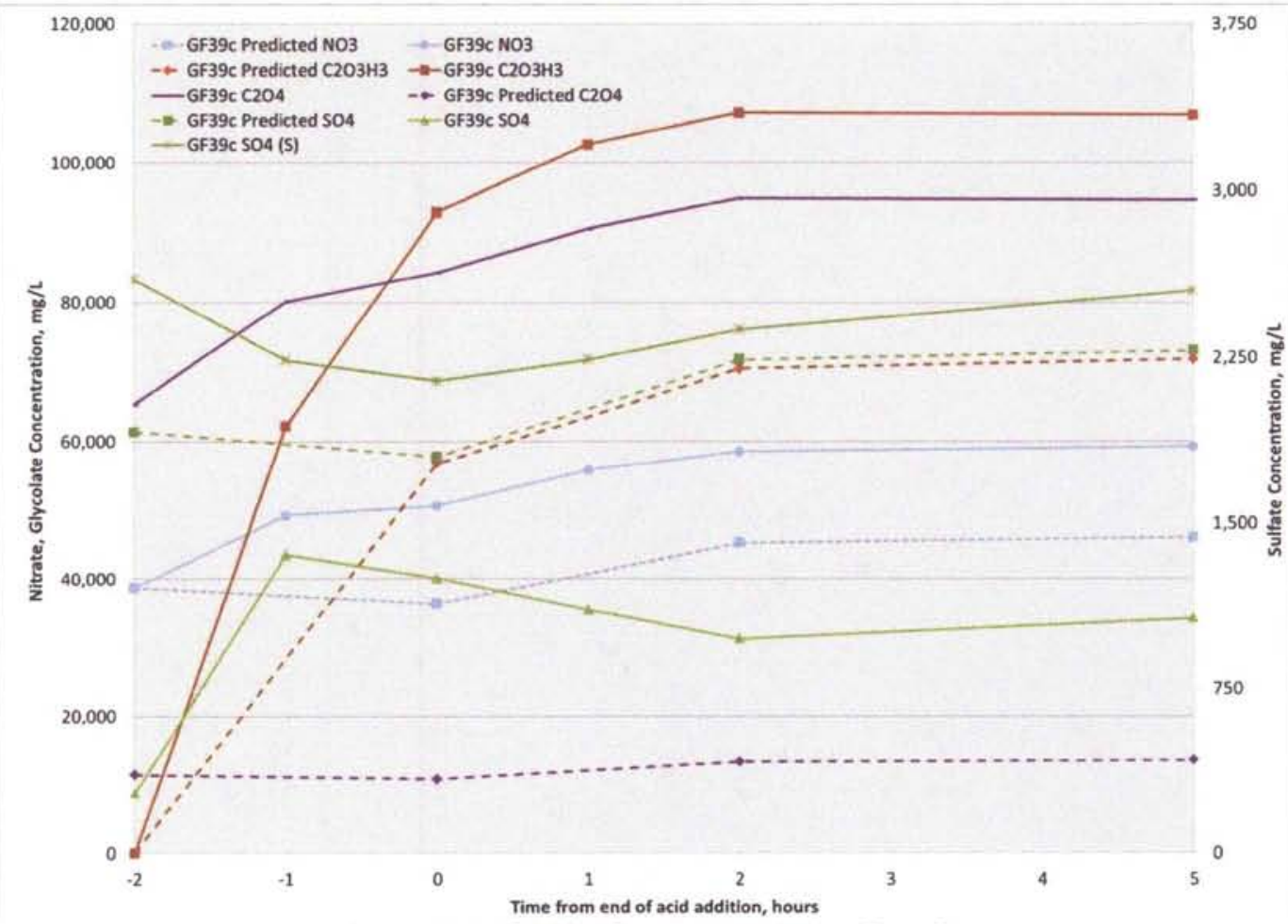

Figure D-5. GF39c Supernate Anion Results

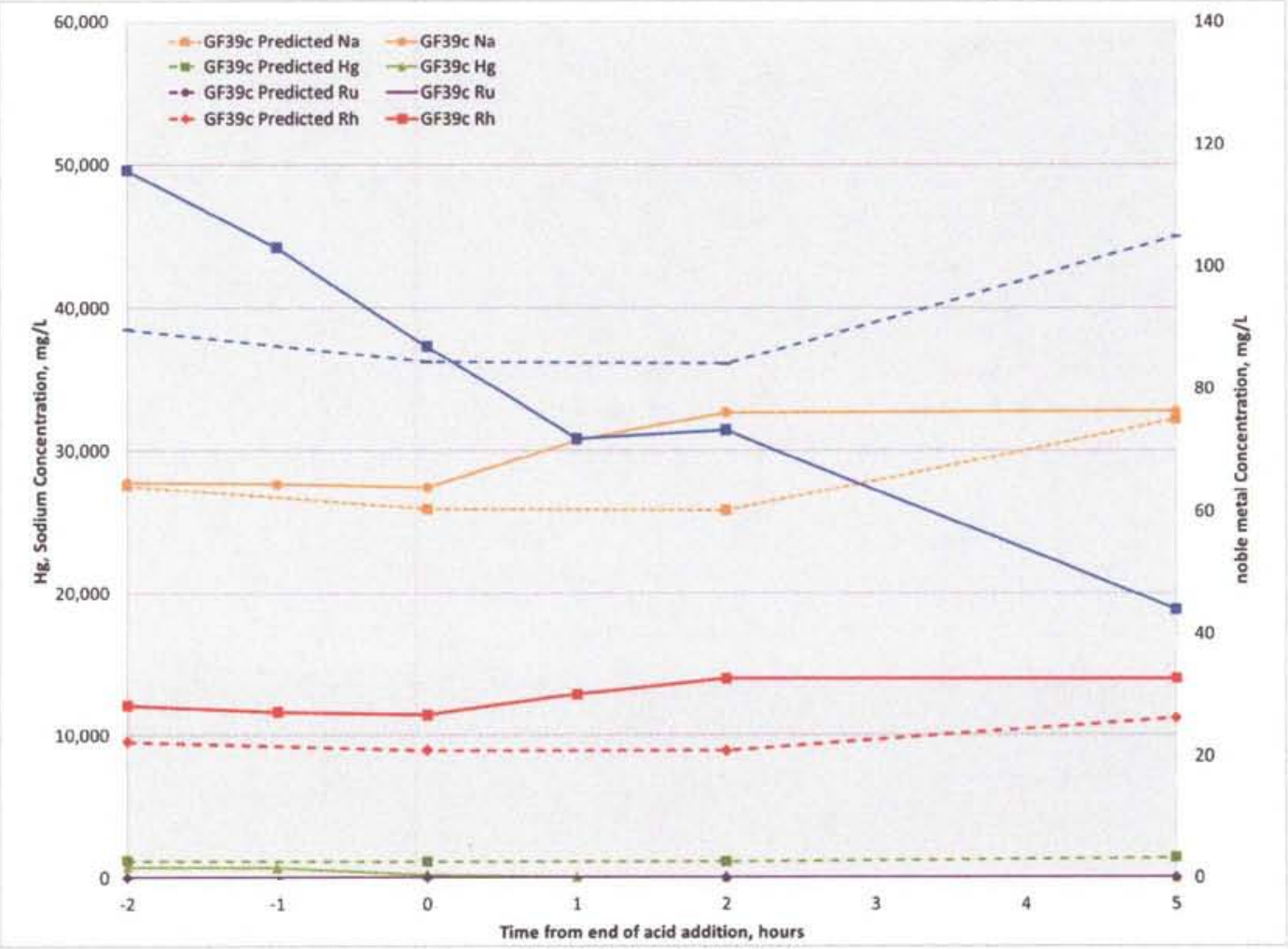

Figure D-6. GF39c Supernate Cation Results 
SRNL-STI-2012-00018

Revision 1

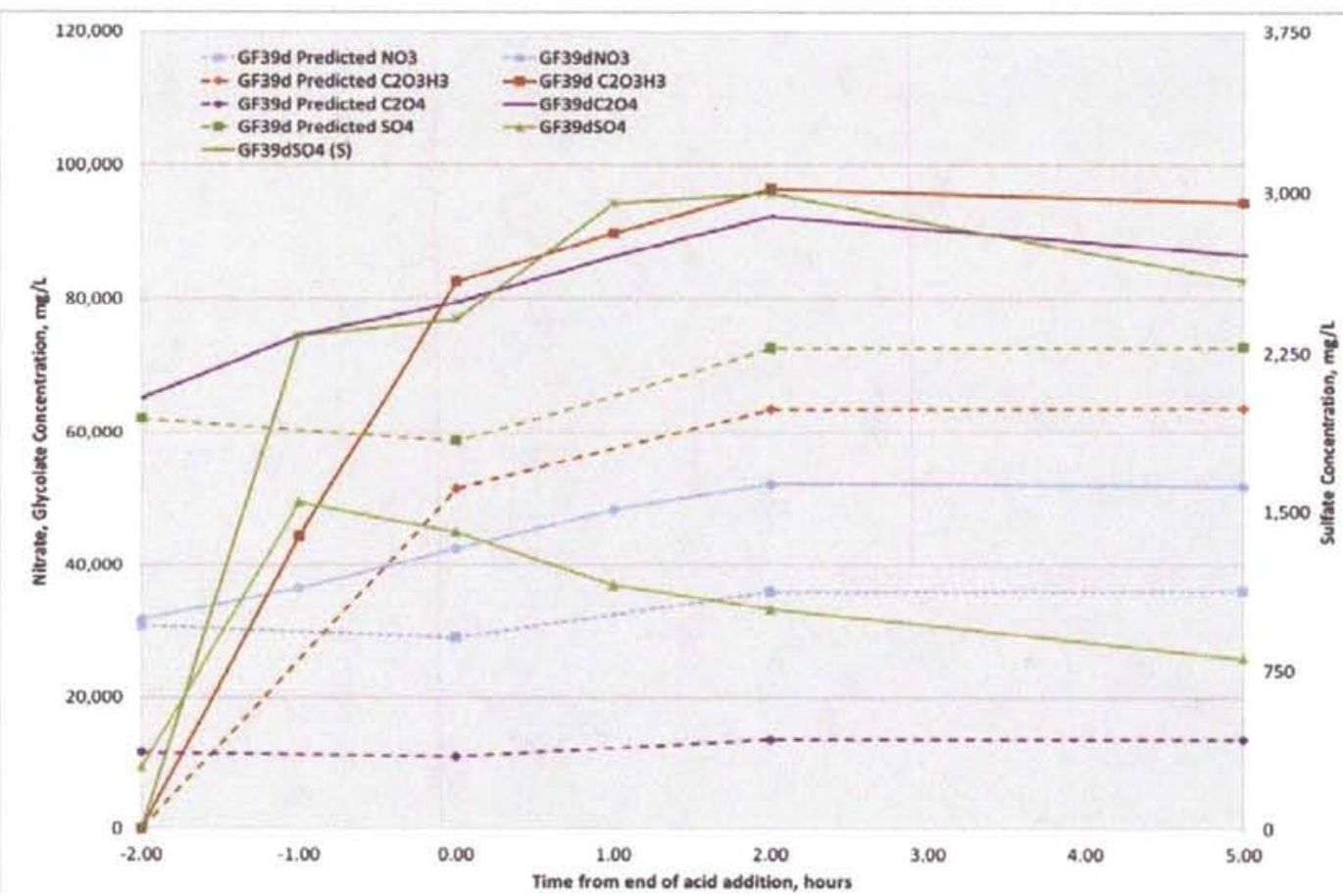

Figure D-7. GF39d Supernate Anion Results

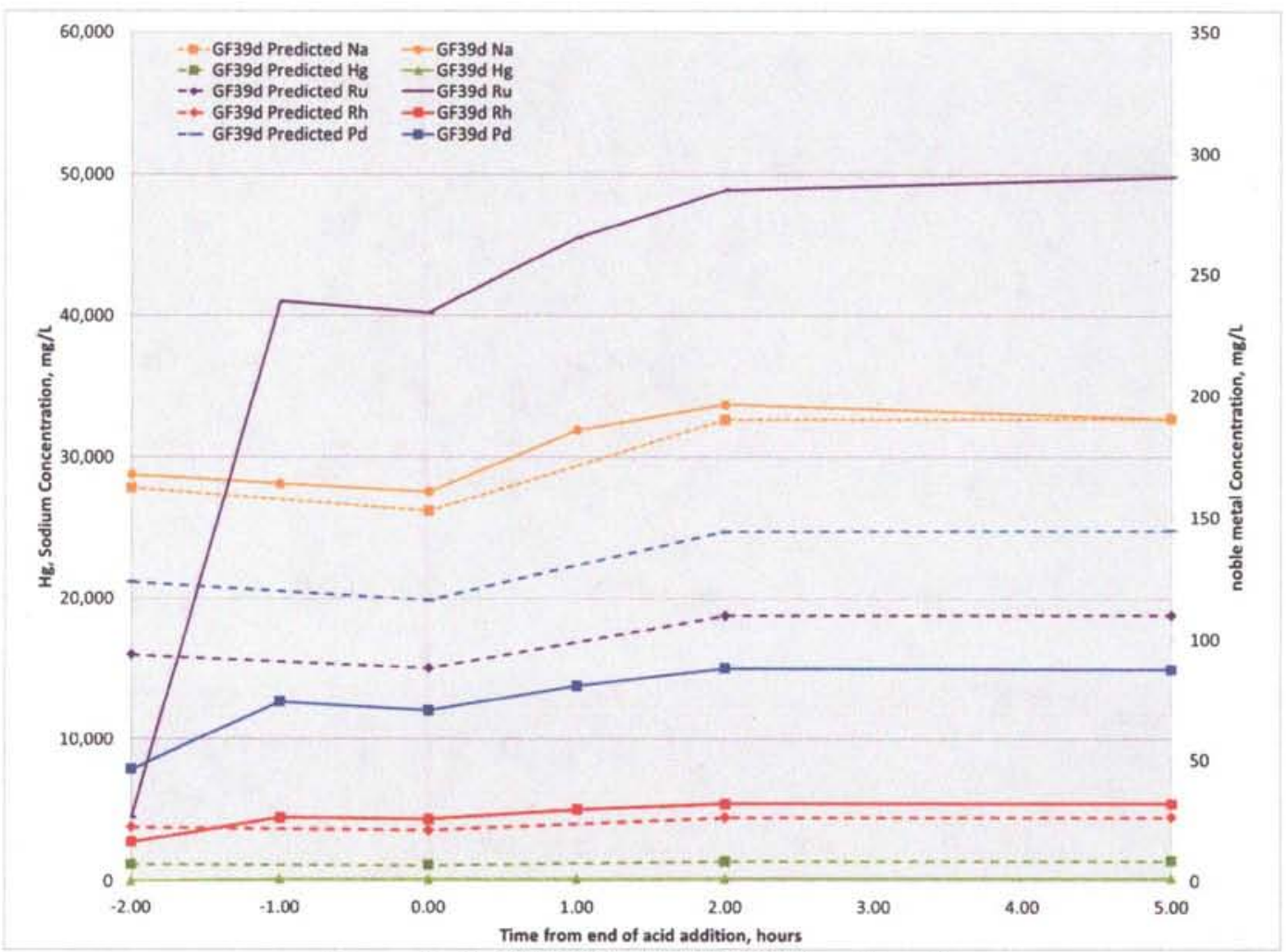

Figure D-8. GF39d Supernate Cation Results 


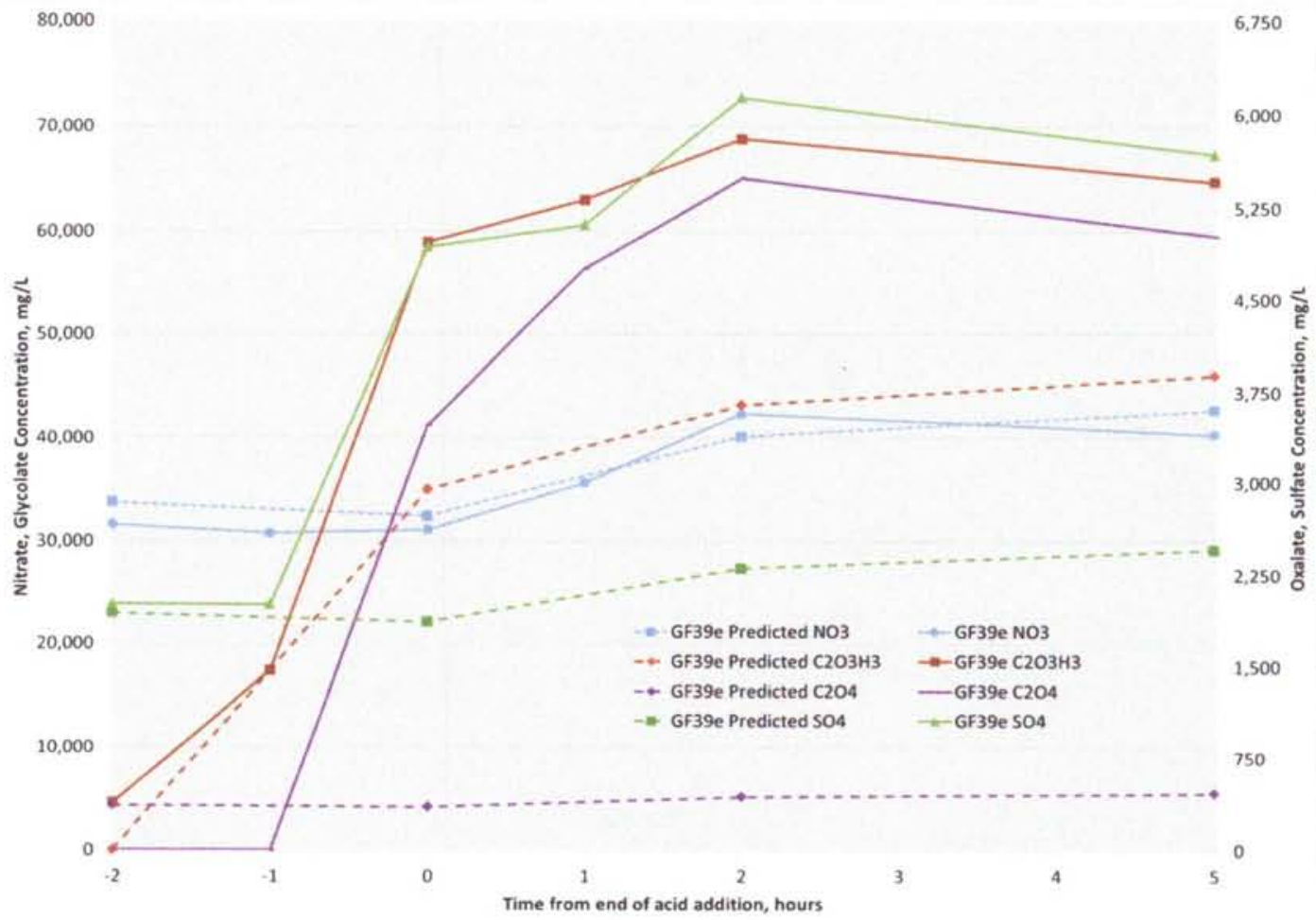

Figure D-9. GF39e Supernate Anion Results

30,000

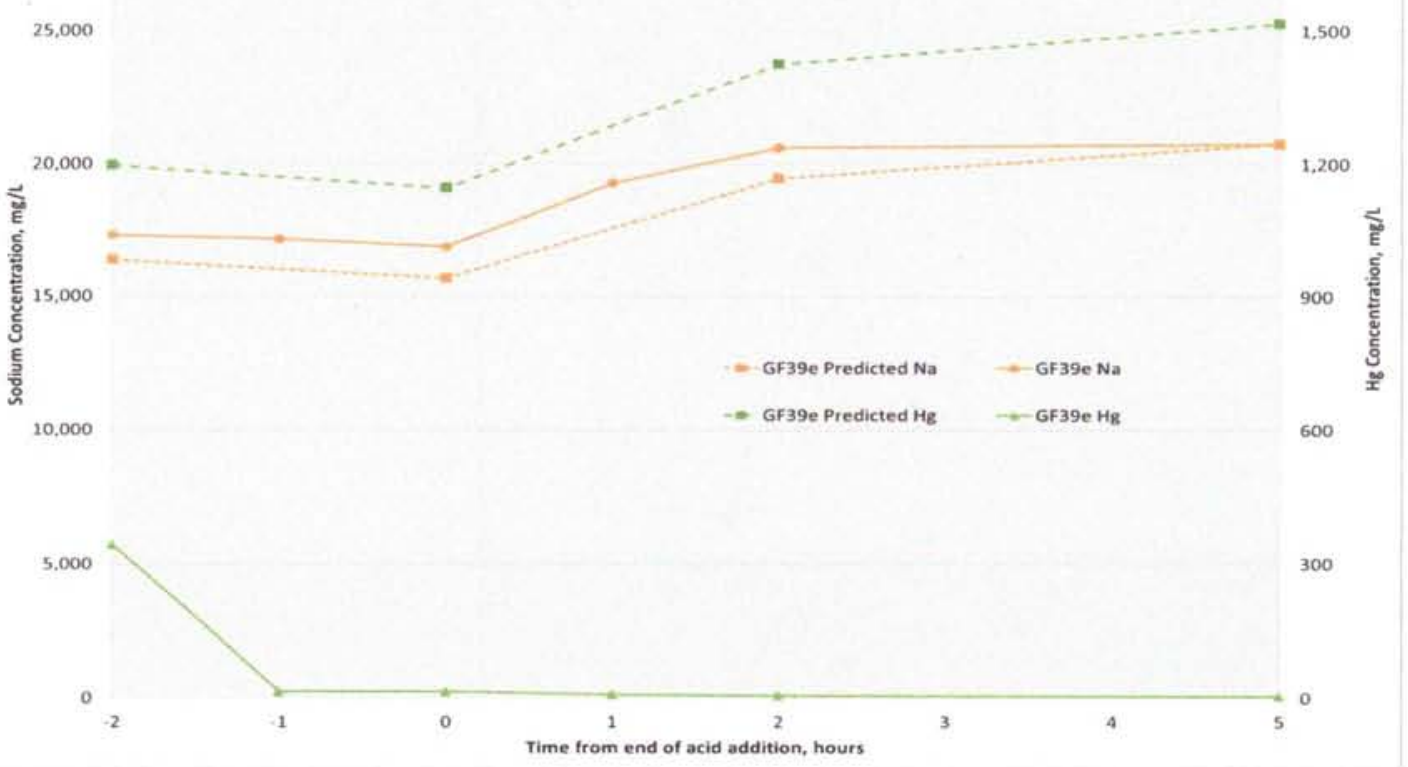

Figure D-10. GF39e Supernate Cation Results 


\section{Distribution:}

K. M. Fox, 999-W

S. D. Fink, 773-A

B. J. Giddings, 786-5A

C. C. Herman, $999-W$

S. L. Marra, 773-A

F. M. Pennebaker, 773-42A

W. R. Wilmarth, 773-A

Records Administration (EDWS)

J. W. Amoroso, 999-W

C. J. Bannochie, 773-42A

J. M. Bricker, 704-27S

D. R. Click, 773-A

T. L. Fellinger, 704-26S

A. Samadi-Dezfouli

J. M. Gillam, 766-H

B. A. Hamm, 766-H

E. W. Holtzscheiter, 704-15S

J. F. Iaukea, 704-30S

P. R. Jackson, DOE-SR, 703-46A

V. Jain, 704-30A

M. T. Keefer, 766-H

D. C. Koopman, 999-W

M. A. Rios-Armstrong, 241-156A

D. W. Mcllmoyle, 766-H

T. A. Le, 766-H

J. E. Occhipinti, 704-S

J. M. Pareizs, 773-A

D. K. Peeler, 999-W

J. W. Ray, 704-S

H. B. Shah, 766-H

D. C. Sherburne, 704-S

A. V. Staub, 704-27S

M. E. Stone, 999-W

K. H. Subramanian, 766-H

J. R. Zamecnik, 999-W 